\begin{abstract}
Universidade de São PaUlo
FACUldadE DE Filosofia, LETRAS E CiÊnCIAS HumanaS

DEPARTAMENTO dE LETRAS ClásSiCAS E VERNÁCULAS

Programa de Pós-GraduaÇÃo EM Filologia E LínguA PORTUGUESA
\end{abstract}

RENATA BARBOSA VICENTE

INICIAR É ABSTRATO? É O LUGAR, É O TEMPO, É O ESPAÇO DO
CAOS COGNITIVO

Versão Corrigida 
Renata Barbosa Vicente

\section{INICIAR É ABSTRATO? É O LUGAR, É O TEMPO, É O ESPAÇO DO CAOS COGNITIVO}

Tese de Doutorado apresentada ao Programa de Pós-graduação em Filologia e Língua Portuguesa, do Departamento de Letras Clássicas e Vernáculas, da Faculdade de Filosofia, Letras e Ciências Humanas da Universidade de São Paulo, como requisito parcial para a obtenção do título de Doutor em Filologia e Língua Portuguesa.

Orientadora: Profá. Dra. Maria Célia Pereira Lima-Hernandes

Versão Corrigida

São Paulo

Fevereiro / 2014 
Renata BARbosa Vicente

\title{
INICIAR É ABSTRATO? É O LUGAR, É O TEMPO, É O ESPAÇO DO CAOS COGNITIVO
}

Tese de Doutorado apresentada ao Programa de Pós-graduação em Filologia e Língua Portuguesa, do Departamento de Letras Clássicas e Vernáculas, da Faculdade de Filosofia, Letras e Ciências Humanas da Universidade de São Paulo, como requisito parcial para a obtenção do título de Doutor em Filologia e Língua Portuguesa.

Orientadora: Profa. Dra. Maria Célia Pereira Lima-Hernandes

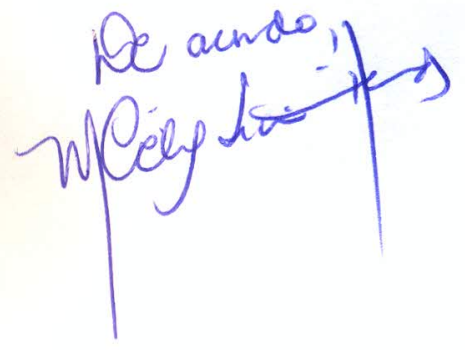

\author{
São Paulo
}

Fevereiro / 2014 
Autorizo a reprodução e divulgação total ou parcial deste trabalho, por qualquer meio convencional ou eletrônico, para fins de estudo e de pesquisa, desde que citada a fonte. 
Banca Examinadora

Membros titulares:

Profa. Dra. Maria Célia Pereira Lima-Hernandes

FFLCH-USP

(Orientadora)

Profa. Dra. Valéria Viana Sousa

UESB

Profa. Dra. Jussara Abraçado

UFF

Profa. Dra. Sheila Cavalcante Caetano

UNIFESP

Prof. Dr. José Carlos Azeredo

UERJ 


\section{Membros suplentes:}

\section{Profa. Dra. Cristina Lopomo Defendi}

IFSP

Prof. Dr. Osvaldo Humberto Leonardi Ceschin

USP

Prof. Dr. Roberval Teixeira e Silva

UMAC

Prof. Dr. Paulo Eduardo Ramos

UNIFESP

Profa. Dr. Edvaldo Balduino Bispo

UFRN 
Dedico a

Deus,

Décio,

Isa, Antonio e Paula 


\section{AGRADECIMENTOS}

A Deus, que sempre me deu forças para continuar na trajetória árdua da pesquisa, livrando-me dos maus rumores, que muitas vezes cercam o ser humano e lançam-no à lama.

À minha orientadora, Profa. Dra. Maria Célia Pereira Lima-Hernandes, pessoa por quem eu tenho profunda admiração e em quem me espelho para caminhar na carreira de pesquisadora. A esta mulher sensível e forte, cuja competência profissional ampliou-me a formação científica com palavras de sabedoria, muitas vezes doses de estímulos em meio às minhas inseguranças, serão eternos os meus agradecimentos.

Ao Prof. Dr. Osvaldo Humberto Leonardi Ceschin e ao Prof. Dr. Roberval Teixeira e Silva, que contribuíram para o desenvolvimento deste trabalho, abordando na qualificação pontos fundamentais da pesquisa e manifestando sugestões que permitiram a ampliação do meu conhecimento.

Ao Prof. Dr. José Carlos Azeredo, à Profa. Dra. Jussara Abraçado, à Profa. Dra. Sheila Cavalcante Caetano e à Profa. Dra. Valéria Viana Sousa por aceitarem participar da banca de defesa e pelo tempo dispendido na leitura desta tese.

Ao Décio, meu marido, que todas as vezes compreendeu a minha ausência em dias e madrugadas, bem como pela disposição em estar me acompanhando nas minhas empreitadas.

À minha mãe que, com seu espírito de mulher guerreira, me ensinou a ir buscar, lutar e jamais desistir dos meus sonhos.

Ao meu pai, que sempre me ensinou o caminho honesto e humilde da vida, fazendo-me entender que muitas vezes para alcançar um objetivo é necessário refletir sobre as ações e até se redimir das atitudes impulsivas que me levavam ao desespero.

À minha querida irmã, Paula, que com seu jeito manso e suave de falar sempre me provou quão importante é manter a calma nos momentos de ansiedade. 
Aos amigos do grupo o Grupo de Pesquisa CNPq-USP "Mudança Gramatical do Português - Gramaticalização", rebatizado devido a um avanço maior e especialização mais estrita dos fenômenos estudados como Grupo de Pesquisa Linguagem e Cognição, os quais sempre ouviram e refletiram juntos sobre as questões mais conflituosas do trabalho, fazendo-nos perceber que em meio a cegueira das dúvidas, talvez a busca de uma resposta simples seja a luz da grande descoberta.

À FUVEST pela disponibilização das redações, que compôs o corpus desta pesquisa.

À Lídia Spaziani pelo abstract.

Aos amigos e professores do Centro Universitário Fundação Santo André, cuja menção aos nomes seria inviável e injusta, uma vez que poderia incorrer no erro de deixar de citar algum. Sei que muitos torceram pela minha caminhada.

Ao Sidney Pedro da Silva pelas contribuições com os gráficos.

Ao Bento, que me acompanhou nas noites frias aquecendo meus pés enquanto trabalhava e que, muitas vezes, ainda que irracionalmente, cobrava-me beijos e carinhos. 


\section{[O E Jamanho do Espaço]}

A medida do espaça somo nós, homens,

Baterias de cozinha e jazz-band,

Estrelas, pássaros, satélites perdidos,

Aquele cabide no recinto do men quarto,

Com toda a minha preguiça dependurada nele...

O espaço, que seria dele sem nós?

Thas a que enche, mesmo, toda a sua

infinitude

É a poerma!

- por mais leve, mais breve, por mínimo que seja... 


\section{Resumo}

Esta pesquisa tem como objetivo descrever e analisar, a partir das construções linguísticas usadas para marcar a introdução de um texto dissertativo-argumentativo, pela perspectiva da Gramaticalização e da Cognição, as categorias linguísticas mais frequentes. Para isso usamos um corpus que totaliza 1600 redações de vestibular da FUVEST (Fundação para o vestibular - USP), produzidas no período de 2004 a 2011 , sendo $50 \%$ delas as melhores e as outras $50 \%$ as piores consideradas pela banca corretora. Teoricamente, fundamentamos esta pesquisa nos estudos sobre Cognição, a partir de Tomasello (2003), Damásio (2011), Del Nero (1997) e sobre Gramaticalização Heine, Claudi e Hünnemeyer (1991), Bybee (2010). Todo o material analisado teve tratamento quantitativo e qualitativo e chegou-se à determinação de que a categoria espaço é a categoria cognitiva mais frequente na defesa de uma tese e difere da categoria lugar. Foi possível, assim, constatar que espaço, embora em vários contextos seja utilizado como sinônimo de lugar, sob o ponto de vista linguístico-cognitivo lugar tem caráter mais concreto, por determinar localização física, enquanto espaço situa-se mais à direita do continuum das categorias cognitivas propostas por Heine, Claudi e Hünnemeyer (1991), após a categoria tempo, apontando para maior grau de abstração metafórica. Pudemos evidenciar que o processamento cognitivo para a produção textual envolve vários fatores mentais como o protosself (condição básica ao indivíduo), self central (todo o conhecimento adquirido) e self autobiográfico (a forma de externalizar o conhecimento adquirido em texto escrito). Destacamos também, a forma como o candidato começa uma dissertação, procurando criar um espaço conjunto de atenção, que é resultado de todos esses selves trabalhando juntos para a (inter)subjetividade materializada via categorias cognitivas.

Palavras-chave: Gramaticalização; Categoria Linguística; Estágios mentais; Cognição; Redação. 


\section{Abstract}

This research has as aim to describe and analyze, from the linguistic constructs used to mark the introduction of a argumentative essay text, from the perspective of Grammaticalization and Cognition, the most frequent linguistic categories. So we use a corpus of essays totaling 1600 entrance FUVEST exam (Foundation for the exam - USP), produced in the period 2004-2011, 50\% of them the best and the other $50 \%$ considered the worst by the examining board. Theoretically this research is based on studies about Cognition, from Tomasello (2003), Damasio (2011), and Del Nero (1997), about Grammaticalization, the bases are Heine, Claudi and Hünnemeyer (1991), and Bybee (2010). All analyzed material had quantitative and qualitative treatment, from this was found a determination that the space category is the most frequent cognitive category in the defense of a thesis and differs from place category. It was thus possible to observe that space, although in various contexts is used as a synonym of place, from the linguistic-cognitive point of view place has more concrete aspect, for determining physical location, while space is located more to the right cognitive categories continuum proposed by Heine, Claudi and Hünnemeyer (1991), after the time category, pointing to a higher degree of metaphorical abstraction. We found that the cognitive processing for text production involves several factors such as mental protosself (basic condition to the individual), core self (all acquired knowledge) and autobiographical self (how to externalize the knowledge acquired in the written text). We also note how the candidate begins an essay, trying to create a space set of attention, which is a result of all these selves working together for the (inter) subjectivity materialized via cognitive categories.

Key-words: Grammaticalization, Linguistic Category, Mental Stages, Cognition, Essay. 


\section{Lista de Quadros}

Quadro 1: Três estágios do self. (Damásio, 2011, p. 225)............................... 34

Quadro 2: Esquema do modelo de interação verbal de Dik............................... 44

Quadro 3: Resumo da Atenção Conjunta....................................................... 67

Quadro 4: Características da comunicação humana e não-humana segundo Tomasello.

Quadro 5: Metáforas temporais............................................................... 97

Quadro 6: Acepções de tempo (HOUAISS, 2001).......................................... 98

Quadro 7: Acepões da palavra espaço (HOUAISS, 2001)............................... 100

Quadro 8: Conceitos de espaços por área................................................... 105

Quadro 9: Resumo das Propostas da FUVEST........................................... 120

Quadro 10: Resumo das 18 formas de iniciar um texto................................... 131

Quadro 11: Estágios dos se/ves e a Produção de Cultura................................. 139

Quadro 12: O self autobiográfico e os mecanismos neurais (Damásio, 2011, p.263)

Quadro 13: Gradaçao de complexidade espacial 185

Quadro 14: Graus de complexidade dos chunks. 206 


\section{Lista de Gráficos}

Gráfico 1: Ano 2004 - Localização das expressões temporais

Gráfico 2: Ano 2004 - Expressões locativas topicalizadas e focalizadas

Gráfico 3: Ano 200 - Expressões temporais e locativas topicalizadas e focalizadas

Gráfico 4: Ano 2005 - Expressões temporais topicalizadas e focalizadas.

Gráfico 5: Ano 2005 - Expressões locativas topicalizadas e focalizadas

152

Gráfico 6: Ano 2005 - Expressões temporais e locativas topicalizadas e focalizadas

Gráfico 7: Ano 2006 - Expressões temporais topicalizadas e focalizadas.

Gráfico 8: Ano 2006 - Expressões locativas topicalizadas e focalizadas

Gráfico 9: Ano 2006 - Expressões temporais e locativas topicalizadas e focalizadas

Gráfico 10: Ano 2007 - Expressões temporais topicalizadas e focalizadas.

Gráfico 11: Ano 2007 - Expressões locativas topicalizadas e focalizadas

Gráfico 12: Ano 2007 - Expressões temporais e locativas topicalizadas e focalizadas

Gráfico 13: Ano 2008 - Expressões temporais topicalizadas e focalizadas.

Gráfico 14: Ano 2008 - Expressões locativas topicalizadas e focalizadas

Gráfico 15: Ano 2008 - Expressões temporais e locativas topicalizadas e focalizadas.

Gráfico 16: Ano 2009 - Expressões temporais topicalizadas e focalizadas. 160

Gráfico 17: Ano 2009 - Expressões temporais topicalizadas e focalizadas. 160

Gráfico 18: Ano 2009 - Expressões locativas topicalizadas e focalizadas. 
Gráfico 19: Ano 2010 - Expressões temporais topicalizadas e focalizadas...

Gráfico 20: Ano 2010 - Expressões locativas topicalizadas e focalizadas

Gráfico 21: Ano 2010 - Expressões temporais e locativas topicalizadas e focalizadas

Gráfico 22: Ano 2011 - Expressões temporais topicalizadas e focalizadas. 164

Gráfico 23: Ano 2011 - Expressões locativas topicalizadas e focalizadas. 164

Gráfico 24: Ano 2011 - Expressões temporais e locativas topicalizadas e focalizadas. 


\section{Lista de Figuras, Organogramas e Continuuns}

Figura 1: Torre do Relógio do Big Ben........................................................ 90

Figura 2: Cérebro humano...................................................................... 92

Figura 3: Cartaz do filme Tempos Modernos................................................ 94

Figura 4: Vista lateral da Catedral da Sé em São Paulo.................................... 95

Organograma 1: Campo Semântico do termo Passado.................................... 133

Organograma 2: Campo Semântico do termo Presente.................................... 134

Organograma 3: Campo Semântico do termo Futuro......................................... 134

Continuum 1: Estágios dos selves na perspectiva Damasiana.......................... 36

Continuum 2: Gradação de mobilização de Informações.................................. 140

Continuum 3: Avaliação de exemplos dos padrões do continuum de 185 complexidade. 


\section{Sumário}

\section{INTRODUÇÃO \\ CAPÍTULO I}

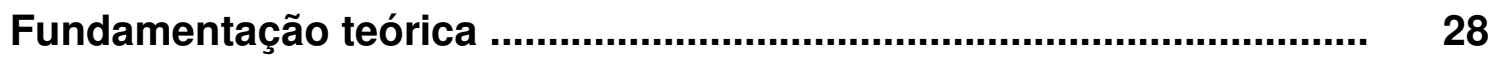

1.1 Um diálogo entre Cognição e Linguagem.............................................. 28

1.1.1 A construção da mente consciente .............................................. 32

1.1.2 Elementos do processamento mental nos estágios dos selves.......... 38

1.1.3 A evolução humana e o desenvolvimento da linguagem.................... 49

1.1.4 O processamento cognitivo linguístico........................................... 53

1.2 Funcionalismo e Cognição: da ideia à codificação sintática......................... 61

1.2.1 Compreendendo Língua........................................................... 61

1.2.2 O recorte funcionalista sob a perspectiva cognitiva............................. 63

1.2.2.1 Princípios funcionalistas.................................................... 78

1.2.3 A Gramaticalização em processo.................................................. 82

1.2.3.1 O princípio da unidirecionalidade.......................................... 86

\section{CAPÍTULO II}

Tempo e Espaço: construindo o primeiro parágrafo............................... 88

2.1 A metaforização do tempo............................................................... 88

2.2 Espaço: explorando conceitos............................................................. 99

\section{CAPÍTULO III}

Procedimentos técnicos e científicos …............................................. 107

3.1 Caracterizando o corpus............................................................... 107

3.2 Problemas sobre a delimitação do objeto................................................. 122 
3.3 Estratégia de referendação

\section{CAPÍTULO IV}

Estudo descritivo dos dados.............................................................. 137

4.1 Os dados: para uma abrangência holística............................................ 137

4.2 Iniciar é a parte mais difícil.................................................................. 147

4.3 Padrões de uso da categoria de espaço.................................................. 166

4.4 Mobilizando a bagagem discursivo-pragmática....................................... 190

4.5 A polaridade negativa no parágrafo introdutório.......................................... 207

4.6 Livro didático ................................................................................. 209

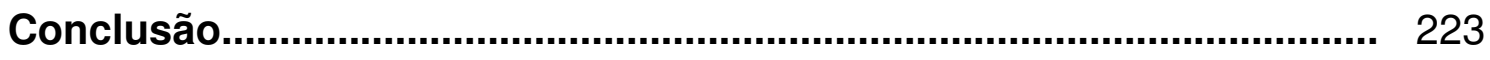

Referências Bibliográficas............................................................... 236

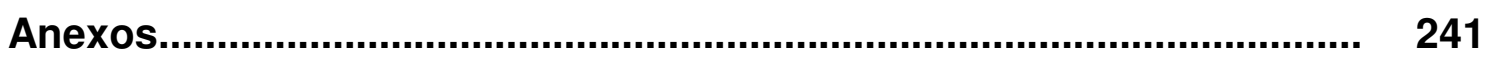




\section{Iniciar é abstrato? É o lugar, é o tempo, é o espaço do caos cognitivo}

\section{Introdução}

Iniciar é a parte mais difícil do texto. Iniciar é dar vida ao texto. Iniciar é descobrir o espaço de persuadir o outro em um curto período de tempo.

Renata Barbosa Vicente

"Iniciar um texto é a parte mais difícil." Em nossa experiência docente presenciamos muitos alunos declararem que não sabem como começar a redação. Essa situação foi mote para que nos inspirássemos a realizar esta pesquisa. O texto, sendo uma unidade linguística que materializa o discurso, ou seja, as posições discursivo-pragmáticas dos indivíduos, em sua forma escrita, muitas vezes torna-se um obstáculo intransponível para que a comunicação se efetive. Em situações interativas, via escrita formal, como é o caso das redações que integram o corpus sob análise nesta tese, o usuário da língua deve afastar-se da oralidade e organizar o que pretende comunicar basicamente em três blocos: início, meio e fim. O início é o lugar mais comumente associado à alta dificuldade, daí nosso interesse. 
Para desenvolver esta pesquisa, selecionamos como alvo de estudo um texto delimitado em sua forma e seu conteúdo. Assim, a tipologia dissertaçãoargumentativa, que prevê uma estrutura organizacional canônica dividida em três blocos, coesamente apresentados, foi o que mais apropriadamente se prestava ao estudo da complexidade gramatical. Assim, focalizar introdução, desenvolvimento e conclusão, e restringir a análise à primeira parte, na verdade, reflete a hipótese da situação mais difícil de uma interação, pois é o momento da chegada, do contato com o desconhecido.

Selecionar a introdução de redações que, em tese, trariam um alto grau de preocupação por parte do escrevente combinada ao alto desempenho linguístico, típico de uma segunda fase de vestibular, naturalmente nos conduziu a um necessário recorte metodológico maior: estudar introduções das redações de vestibular da Fundação Universitária para o Vestibular da Universidade de São Paulo (FUVEST), um dos vestibulares mais concorridos no Brasil.

Seria justo perguntar por que a introdução é considerada tão complexa em sua execução. E a resposta é óbvia: tentar estabelecer o diálogo em algumas situações de nosso dia a dia demanda a busca não somente por adequação de abordagem, mas também por adequação linguística. A busca da forma eficiente de aproximação com o outro, seja no ponto de ônibus, seja no elevador, seja na fila do caixa de supermercado, sempre tem seus efeitos como uma incógnita, que só se resolve no andar da conversa.

Frases, como "Está calor!", "Está frio!", "Não para mais de chover”, "Como está abafado!", "Está demorando!” acabam sendo mobilizadas para lidar com uma 
circunstância complexa. Essa complexidade, no entanto, clama por um tipo similar de construção. Essa semelhança de solução talvez seja fato, porque encontramos nessas frases o lugar seguro para iniciar uma conversa: a circunstância compartilhada.

Muitas são as formas de se iniciar uma conversa, mas essas formas de se iniciar uma dissertação de vestibular não são tão variadas assim.. A despeito desse amplo leque de formas muitas vezes variantes para preencher a posição inicial de um texto falado ou escrito, regras de convivência social (no caso da fala) e regras de ordem linguística (no caso da escrita) confluem para atender ao mesmo princípio universal: todo início de conversa deve prever o compartilhamento de algum interesse, de alguma informação, de algum traço.

Entendemos, no primeiro momento da pesquisa, que é na parte da introdução que a unidade linguística começa tomar forma. Só mais tarde, após consultar alguns dados para compreender o motivo desse início é que nos damos conta de que ele é para muita gente um obstáculo. A pergunta, então, é: por que nos aproximarmos de nossos semelhantes e com eles conversar torna-se uma atividade tão difícil? Será que o texto nasce pronto ou ele toma forma previamente na mente humana? Afinal, se no plano oral, mentalmente o indivíduo busca uma estratégia de contato, então na estratégia escrita talvez isso não fosse diferente.

Para dar conta dessa questão, apoiamo-nos em pressupostos funcionalistas, e voltamos a atenção para o paralelo existente entre codificação linguística e intenção humana. Essa foi a motivação para que recorrêssemos a princípios de iconicidade e a seus subprincípios, à atuação dos planos discursivos fundo e figura 
como estratégias linguísticas para falar de intenções discursivas, a estratégias de aproximação interativa ou outros rótulos que remetam à representação da forma física de aproximarmo-nos do outro para tratar de um tema do qual se imagina que o interlocutor já detenha algumas informações e supõe-se que ele desconheça outras.

O que trazemos aqui permite uma paráfrase com o que afirmou Givón (1979) em sua célebre declaração: "a estrutura da língua reflete a estrutura da mente".: as regras de convivência e de aproximação interativa humana apresentam um paralelo no momento de se construir o primeiro parágrafo de um texto dissertativo. Mesmo o indivíduo pouco tímido sofre com esse primeiro contato. Então, o momento de iniciar um texto qualquer é o momento de maior dificuldade mesmo para o escrevente habilidoso. Achar um liame, uma forma de interação com elementos compartilhados é um obstáculo inicial que se revela suplantado, recorrentemente, pelo que de mais básico e comum temos filogênica e ontogenicamente: as categorias cognitivas de espaço e tempo.

Uma vez transposto o obstáculo do início do texto, a escrita flui desordenadamente e, muitas vezes, sem uma organização definitiva. A escolha da introdução se deve, então, ao que ela representa para todos os escreventes: um obstáculo a ser transposto e um estágio necessário para que a interação se estabeleça. Considerando esse contexto, começam a surgir os primeiros questionamentos acerca de que fatores podem estar relacionados com esse obstáculo. 
De acordo com Brandão (2004) as emoções básicas vivenciadas pela espécie são codificadas no cérebro e as respostas biofísicas originam-se de comandos dessa região. Diante disso, considerando que o vestibular seja uma situação de tensão, de emoção e se manifesta como o momento de maior dificuldade na produção de um texto dissertativo, perguntamo-nos se as emoções poderiam ser codificadas na linguagem via sintaxe.

Se esse indivíduo carrega essas emoções para uma situação nova, ou mesmo que conheça a situação, mas não tenha o domínio dela, considerando a produção escrita, questionamo-nos como o indivíduo baseia-se numa situação já conhecida ou similar, para atuar na nova situação.

Diante desses primeiros questionamentos, consideramos relevante compreender os processos cognitivos que envolvem o processamento da linguagem na mente humana. Para isso, estabelecemos um diálogo entre cognição e linguagem. Esse diálogo não é, como se poderia supor, no entanto, inédito. Mesmo as áreas da neurociências, da psiquiatria e da psicologia têm reconhecido na linguagem um objeto eficiente para alcançar processos mentais. Isso nos permitirá recorrer a vozes de autores como Del Nero (1997) e Damásio (2011), dentre outros. Damásio, por exemplo, defende a ideia de que processamentos mentais remetem a camadas evolutivas da mente. Seus resultados permitem identificar camadas de self (protosself, self central e de self autobiográfico) aliados à complexidade de operações que o indivíduo passa a ter competência de realizar conscientemente .

Então, surge uma outra pergunta: na produção textual para o vestibular: haveria mecanismos linguísticos capazes de denunciar uma mente voltada para a 
produção de cultura, ou seja, a mente num estágio mais evolutivo: o de self autobiográfico? Sabemos que por intermédio da língua o indivíduo é capaz de aproximar ou de distanciar pessoas, de caracterizar-se cultural, social e politicamente. Considerando essa função social da língua, indagamo-nos se a produção escrita também seria aprendida por imitação?

Postos esses questionamentos, conjecturamos que:

(i) as emoções podem ser codificadas na linguagem via sintaxe sim, tendo em vista algumas reações biofísicas no indivíduo durante uma situação de tensão, tais como a sudorese, perturbações na fala (espécies de gagueira) e os famosos "brancos" são exemplos que nos levam a acreditar na possibilidade dos indivíduos terem a linguagem afetada pela emoção.

(ii) o indivíduo basea-se numa situação já conhecida ou similar, para atuar na nova situação. Como já mencionado, nesta seção, se o indivíduo numa interação face a face procura estabelecer contato com o outro utilizando basicamente os mesmos enunciados (Que chuva! Que sol!), conjecturamos que na construção escrita, para resolver tal situação, ele use 'frames' e tipos narrativos inerentes à idade mais tenra do indivíduo.

(iii) na produção textual para o vestibular, há mecanismos linguísticos capazes de denunciar o estágio evolutivo da mente. Acreditamos que os textos produzidos por indivíduos que participam do processo de seleção do vestibular da FUVEST apresentam gradiência cultura e 
possivelmente isso se relacione com os três estágios dos selves, pois quanto mais o indivíduo demonstrar cultura e habilidade em produzir um texto, mais avançado é o estágio evolutivo da mente.

(iv) a produção escrita seja aprendida por imitação. É possível aprendemos por imitação, aos termos contatos com outros textos, ou mesmo com os exemplos do livro didático, passamos a reproduzi-los com base naquilo que já conhecemos, que nos serve de parâmetro para novas produções de um texto.

Mas as reflexões não param por aí. Retomemos o que temos de comum filogênica e ontogenicamente: as categorias cognitivas de espaço e de tempo. De acordo com Heine et alii (1991a), as categorias cognitivas seguem uma ordenação, pela qual se observa um processo de abstratização contínuo: pessoa > objeto > processo $>$ espaço $>$ tempo $>$ qualidade. Essa unidirecionalidade permitiu-nos indagar se as introduções poderiam ser categorizadas.

Observando as primeiras amostras, hipotetizamos que sim, dado ao alto índice de ocorrências de expressões circunstanciais, como as de lugar e de tempo. A dúvida em categorizar expressões como "na sociedade moderna" e "o Brasil" nos levou a questionar se, por exemplo, esses termos poderiam ser enquadrados em uma mesma categoria. Aliás, em qual categoria? Espaço? Tempo? Espaço é o mesmo que lugar? Foi aí que começamos a questionar o estatuto organizacional das categorias cognitivas. Será que a organização não seria lugar > tempo > espaço? Sempre sendo operadas e em graus de abstratização crescentes da esquerda para a direita. 
Ao considerar esses aspectos, era preciso clareza sobre a definição de lugar, tempo e espaço. Para nós, era evidente que lugar tratava-se de um local geográfico. E o tempo e o espaço, o que eram? Essas duas categorias nos pareciam tão complexas que achamos por bem, inclusive, recorrer as diferentes áreas Física, Neurociência e, especialmente, a Linguística, pois faremos uma discussão, de orientação funcionalista, sobre essas categorias para demonstrar a tese de que elas continuam fazendo o que sempre fizeram muito bem na evolução da raça humana: construir a coerência no diálogo com os co-específicos.

Uma vez que, ainda nos primeiros dados analisados, percebíamos um número significativo dos candidatos recorrer a lugar, tempo e espaço para a primeira expressão no texto dissertativo-argumentativo, outra pergunta surgiue: Por que recorrem a tais categorias? Será uma resposta ao treino escolar para a escrita? 0 livro didático contribui para esse treino? Será, contudo, que a escola ensina o indivíduo a dar um primeiro passo discursivo numa direção? De onde virá a forma empregada pelo indivíduo para "quebrar o gelo" numa proposta textual?

Influenciados por tais indagações, intuímos que isso viesse de suas raízes dialógicas. Na situação de produção de texto, equivaleria às regras habituadas durante o comportamento escolar em língua portuguesa: regras gramaticais e formas textuais.

Para dar conta dessas questões e outras, que foram se desdobrando, organizaremos esta tese em a quatro capítulos conforme segue:

- No primeiro capítulo, teceremos ideias que permitam revelar a fundamentação teórica que se divide em duas grandes seções. A primeira estabelece um diálogo 
entre cognição e linguagem evidenciando a relação entre ontogenia e filogenia. Nela, apresentaremos subseções que trarão à baila teorias sobre a construção da mente, sobre os elementos do processamento mental nos estágios dos selves, sobre a evolução humana e o desenvolvimento da linguagem e, por fim, sobre o processamento cognitivo linguístico. A segunda seção estabelece uma interface entre funcionalismo e cognição. É nesse segmento que entrelaçaremos uma discussão conceptual sobre as relações entre gramática e categorias cognitivas;

- No segundo capítulo, serão apresentados os conceitos de tempo e de espaço por se tratarem de duas categorias cognitivas muito presentes nos parágrafos introdutórios dos candidatos ao vestibular, conforme verificamos nos primeiros dados analisados. É nessa seção que poderemos identificar se essas categorias de fato nos acompanham desde as situações mais simples do dia a dia até os momentos mais complexos, que demandam elementos também mais complexos, como as operações mais abstratas derivadas da ação do cérebro humano. Como muito do que carregamos nos é transferido culturalmente, via interações, consultar uma obra lexicográfica pode ser uma saída interessante.

- No terceiro capítulo, discorreremos sobre os encaminhamentos metodológicos, em que registraremos o modo como as amostras foram reunidas. Mas esse trabalho não estaria completo se não deixássemos um espaço para lidar com a complexidade linguística. Essa questão vem pelos resultados das análises do corpus, que é prioritariamente composto pelas redações do vestibular da FUVEST, instituição que nos cedeu o material do período de 2004 a 2011 para estudo. É nesse espaço que apresentaremos tema a tema e proposta a proposta 
de modo a observar se o tema não influencia o escrevente durante o nosso objeto de análise. Explanaremos a forma de depreensão dos padrões de uso introdutórios e com essa tarefa, teremos condições de cotejar usos. Ainda nessa seção, apresentaremos as estratégias adotadas para a referendação de usos. Evidentemente, que tudo isso será feito à luz dos fundamentos teóricos apresentados no capítulo II.

- No capítulo quarto, procederemos a um estudo descritivo dos dados com vistas a verificar porque o candidato considera iniciar um texto a parte mais difícil. Saber até que ponto estabelece um diálogo com os excertos apresentados para compreensão do tema, bem como com outros textos trazidos de sua bagagem discursivo-pragmática, pesquisaremos se a estrutura da sentença negativa é presente no parágrafo introdutório e, principalmente, estudaremos a categoria cognitiva espaço, recorte mais específico deste trabalho.

Em seguida, procederemos à exposição das conclusões que se apresentarão com base no que foi analisado nesta pesquisa, de modo a responder aos questionamentos delineados. Por fim, agora que já vencemos o obstáculo da introdução e acreditamos ter encontrado o liame desta produção científica, passaremos ao primeiro capítulo. 


\title{
CAPÍTULO I
}

\section{Fundamentação teórica}

\begin{abstract}
Cérebros são todos complexos; porém, no organismo mais simples, a uma dada situação costuma corresponder a uma única reação: fugir ou lutar. No ser humano, costuma-se engendrar diferentes ações diante do perigo. Essa característica não é pré-gravada e depende de complicadas operações de intermediação entre os sentidos e a motricidade. Quando essa integração é muito complexa, surge o processamento mental como um tipo especial de processamento cerebral. (Del Nero, 1997, p. 33)
\end{abstract}

Esta seção tratará de um diálogo estabelecido entre cognição e mente, viés teórico que permeia este trabalho ao lado da teoria funcionalista da linguagem que dá amparo aos estudos sobre gramaticalização.

\subsection{Um diálogo entre Cognição e Linguagem}

Lidar com cognição a partir de uma perspectiva linguística pode gerar uma certa desconfiança para aqueles que se encontram numa linguística hard, mas 
neurocientistas, psiquiatras e psicólogos ainda não encontraram um objeto mais eficiente para alcançar os processos mentais do que as produções em linguagem e língua. Essa é a principal motivação para que recorramos a esse campo da ciência. Alguns autores foram escolhidos para a construção desse diálogo com o objeto de investigação priorizado por esta tese. Alguns foram leituras de cursos, outros estudos coletivos do grupo de pesquisa e, outros, ainda, fruto de pesquisa bibliográfica sobre o tema. Aqui estarão representadas as vozes de Del Nero (1997), Maturana e Varela (2001), Meyer (2002), Mithen (2002), Pinker (1994, 2008) e Damásio (2011). Cada um deles contribuirá para a constituição da visão que consolidamos da consciência, elemento-chave para o recorte que faremos sobre o objeto desta investigação.

Talvez Darwin estivesse certo já em 1872 e tudo o que fizemos até agora tenha se resumido a ruminar seus achados. Talvez estejamos sendo beneficiados pelo avanço científico da neurociência e de seu impacto nas várias áreas, a oportunidade de melhor compreender como o pensamento se constrói, como a consciência se manifesta em termos de graus, como as intenções são codificadas para o outro, via linguagem.

Brandão, no início do século $\mathrm{XXI}$, talvez tenha ficado também incomodado com sua função de avançar e reconhecer que muito já estava lá, estabelecidíssimo na academia. Darwin já postulava que três princípios permitiam compreender as emoções. Vejamos como relata essa informação Brandão (2004:120-1):

1. Princípio da utilidade dos hábitos - os animais expressam o significado de suas emoções aos outros animais através de alterações comportamentais características. [...] 
2. Antítese - nesta condição, dois estados motivacionais opostos em princípio (por exemplo, comportamento agressivo/cordial) também se expressam de forma oposta. [...]

3. Ação direta do sistema nervoso central - os estados emocionais se ajustam fisiologicamente, e esse ajuste é preparatório para o estabelecimento de um curso apropriado de ação.

Ainda para Brandão, todo experienciamento emocional deriva de mecanismos periféricos e central, o que permite introduzir a cognição como elemento relevante. Emoções básicas vivenciadas pela espécie são codificadas no cérebro e as respostas biofísicas advém de comandos dessa região em interação com estímulos externos. Perguntamo-nos se a intenção pode, assim como essas emoções mais básicas, ser codificada na linguagem via sintaxe. Brandão a esse respeito afirma que a ansiedade, por ser um estado subjetivo de apreensão ou tensão, pode ser acompanhada de sensações físicas e pode, também, afetar as ações motoras, físicas e mentais ou psicológicas. Se isso é fato, não há como negar que a linguagem seja impactada também.

A linguagem é, como defende Givón em suas várias publicações, a esfera de canalização das emoções e intenções dos indivíduos. Mesmo os que não sofrem tanto impacto das emoções, ou seja, que demonstram resiliência a situações que costumam produzir ansiedade não é um superindivíduo, mas um indivíduo comum que aprendeu a produzir em si um significado adaptativo e 'evolutivo'. Explicamos: todo sistema que evolui não o faz se não à custa de adaptação. A língua é um sistema e essa mesma dinâmica pode ser apreendida nos usos. Retomando na consideração sobre o indivíduo resiliente, é certo que, diante de uma situação 
ameaçadora que o assuste, por ser desconhecida, terá maior controle sobre a situação e provavelmente apresentará um resultado motor, físico e psicológico ou mental menos agressivo a si e ao sistema.

Se o indivíduo é um ser holístico, certamente suas sensações, emoções e até mesmo intenções de defesa, de abordagem, de agressividade, por exemplo, podem ser carreadas em situações novas. No entanto, se não tiver domínio do novo ambiente de experienciamento, ainda que a experiência seja já conhecida, a resposta provável é que use um frame, um enquadre já conhecido para resolver a nova situação.

A pergunta que fazemos é: por que esse cérebro resolve assim a situação? Por que se basear em uma cena já conhecida para atuar em nova situação, ainda que similar? A resposta é convergente entre os neurocientistas: o ser humano é uma espécie analógica por natureza (DEL NERO, 1997). Linguistas já têm evidenciado que essa mesma dinâmica se mostra no sistema linguístico (Bybee, 2010; LimaHernandes, 2010,dentre outros).

De tudo o que sabemos, o habitual e funcional na língua e na linguagem assumem padrões de algum modo similares às situações cotidianas. Então, usar o padrão de abordagem e de travamento de contato com um desconhecido numa situação face a face são situações-fonte mobilizadas para construir a abordagem e o travamento de contato na construção de um texto escrito.

Se o texto for muito elaborado e pouco comum à situação cotidiana e não houver treino para isso, então, não somente a situação face a face será o modelo, 
mas também o tipo narrativo, que é um input básico ao indivíduo desde a mais tenra idade. O self age, mas sua resposta não é, assim, aleatória.

Cabe questionar se o indivíduo é um self? Quantos somos em um? Sabemos que já fomos bebê, já fomos criança, já fomos adolescentes e hoje somos adultos, mas também sabemos que, se a vida não for interrompida, ainda outras fases virão. Para onde vão todos os outros selves quando assumimos uma nova fase? Estarão todos em convivência em estado de vigília, prontos para agir quando uma situação conhecida surgir como problema? Talvez, sim.

Não somos sequer capazes de sabermos se seremos idosos. Somente com condições propícias isso será possível. Também não somos capazes de saber se um indivíduo desenvolverá um self autobiográfico ao longo de sua vida. Examinaremos essa questão na próxima seção.

\subsubsection{A construção da mente consciente}

Segundo Damásio (2011), o cérebro constrói a consciência gerando um processo do self em uma mente em estado de vigília. Esse processo pode ser percebido pela evolução do self em três estágios: o protosself, o self central e self autobiográfico. Eles não são estanques, nem autônomos em sua evolução, pois um depende do outro para que o indivíduo alcance a maturação esperada para o próximo estágio. 
Quando o indivíduo encontra-se num estágio mais tenro de desenvolvimento mental, Damásio o insere no estágio do protosself, que representa o próprio organismo (ou a parte biofísica, se é que podemos fazer essa separação) e consiste em uma reunião de imagens que descreve aspectos relativamente estáveis do corpo e gera sentimentos espontâneos do corpo vivo.

Quando o indivíduo é capaz de relacionar, ou seja, fazer uso de seu organismo para interpretar um objeto a ser conhecido, então Damásio o insere no estágio do self central. Depende, naturalmente, do estágio anterior ter ocorrido, pois ele é esteio para o seguinte. Isso significa dizer que todos os seres humanos teriam passado por aquele estágio, exceto os bebês acéfalos ou com transtornos outros que impediriam a constituição do organismo funcional.

Quando um self autobiográfico entra em campo, significa que a mente já é capaz de relacionar múltiplos objetos, tais como uma experiência vivida ou um futuro antevisto, promovendo a interação com o protosself de modo a produzir pulsos de self central em profusão.

Portanto, do ponto de vista evolucionário numa abordagem neurocientífica e numa metodologia de neuroimagem, já é possível reconhecer que, no estágio do protosself, os processos de self orientam e organizam a mente em função das necessidades físicas e biológicas do indivíduo, dando condição para a sobrevivência. Nessa fase, provavelmente não há a consciência, no sentido mais amplo, ou seja, o ser humano ainda não adquiriu o conhecimento que lhe permite vivenciar ou compreender aspectos ou a totalidade do mundo interior. Mais adiante na evolução, à medida que o ser experiencia, começa a gerar uma subjetividade na 
mente, tornando-se ser consciente. Nessa fase, as informações, instruções adquiridas culturalmente, começam a serem usadas para obter e acumular novos conhecimentos sobre o indivíduo. É quando alcançamos um nível mais complexo do self, denominado self central. Mais uma vez, dando continuidade ao processo evolutivo, já no terceiro estágio, o indivíduo passa a manipular, raciocinar sobre o seu conhecimento. Nessa fase, o ser humano vai vivenciar, experimentar ou compreender aspectos ou a totalidade de seu mundo interior

Damásio identifica correlatos nas imagens cerebrais que realiza e se surpreende com os resultados das testagens que faz. Todos esses procedimentos o levam a defender a ideia de que protosself, self central e self autobiográfico são camadas evolutivas da mente. A seguir, apresentaremos a título de ilustração a formulação original de Damásio:

Primeiro estágio: protosself
O protosself é uma descrição neural de aspectos
relativamente estáveis do organismo.
O principal produto do protosself são os sentimentos
espontâneos do corpo (sentimentos primordiais)
Segundo estágio: self central
Um pulso de self central é gerado quando o
protosself é modificado por uma interação entre o
organismo e um objeto e, como resultado, as
imagens do objeto também são modificadasas
imagens modificadas do objeto e do organismo ligam-
se momentaneamente em um padrão coerente a
relação entre o organismo e o objeto é descrita em
uma sequência narrativa de imagens, algumas das
quais são sentimentos
Terceiro estágio: self autobiográfico
o self autobiográfico ocorre quando objetos na
biografia do indivíduo geram pulsos de self central
que são, em seguida, momentaneamente ligados em
um padrão coerente amplo.

Quadro 1: Três estágios do self. (Damásio, 2011, p. 225) 
Transpondo esses conceitos ao que vimos pensando sobre a organização da mente no processo de produção textual, intuímos que o indivíduo passe por um processo de 'vigília', muitas vezes chamado de concentração para a elaboração do plano redacional, que pode ser estruturado da seguinte forma:

(1) momento em que há organização do plano de ideias: Protosself;

(2) contato com o objeto que, no caso, poderiam ser os textos motivadores contidos na proposta, o conhecimento que trazemos de nossas vidas e a situação contextual, ambiente de prova: Self central;

(3) os elementos do self central interagem propiciando a produção do texto, resultando em uma exteriorização da consciência cultural de cada indivíduo que participa do vestibular: Self autobiográfico.

Em concordância com Damásio (2011), reconhecemos os níveis distintos de processamento - mente, mente consciente e mente consciente capaz de produzir cultura - e hipotetizamos que os textos produzidos por indivíduos que participam do processo de seleção do vestibular da FUVEST apresentam gradiência cultura. Testaremos esta hipótese no capítulo IV desta tese, norteados pelas palavras de Damásio:

De fato, existe um self, mas ele é um processo, não uma coisa, e o processo está presente em todos os momentos em que presumivelmente estamos conscientes. Podemos considerar 0 processo do self de duas perspectivas. Uma é a do observador que aprecia um objeto dinâmico - o objeto dinâmico que consiste em certos funcionamentos da mente, certas características de 
comportamento e certa história de vida. A outra perspectiva é a do self como um conhecedor, o processo que dá um foco ao que vivenciamos e por fim nos permite refletir sobre essa vivência. Combinando as duas perspectivas, temos a noção dual de self usada ao longo de todo o livro. Como veremos, as duas noções correspondem a dois estágios do desenvolvimento evolucionário do self, sendo que o self-conhecedor originou-se do self-objeto. Na vida cotidiana, cada noção corresponde a um nível de funcionamento da mente consciente, e o self-objeto tem um escopo mais simples do que o self-conhecedor. (Damásio, 2011:21)

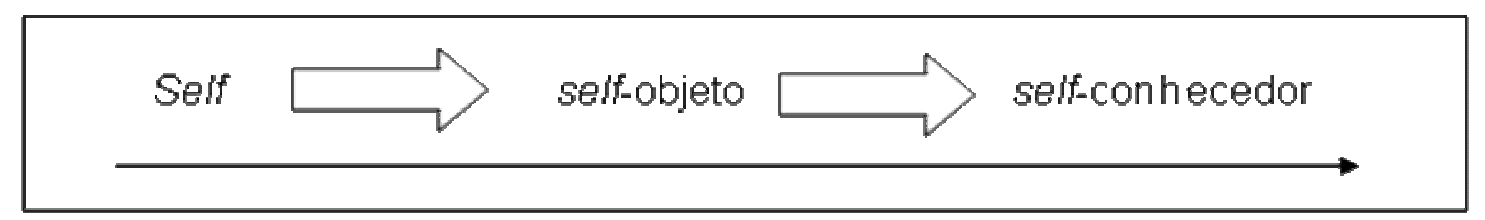

Continuum 1: Estágios dos selves na perspectiva Damasiana

Como refere Damásio, uma mente consciente traz consigo o atributo de incorporar metáforas para suas experiências. Em alguns estágios de maturação, pode mesmo criar metáforas. Com base no modelo de Damásio, postulamos que, num estágio de protosself, as metáforas são adotadas como herança sociocultural (o uso é marcadamente associado ao contexto de aquisição da linguagem em ambiente social); num estágio de self central, as metáforas são produzidas a exemplo das adotadas ou adaptadas a situações novas (a escolha do onde, do quando e de como deriva o julgamento subjetivo); mas, no estágio do self autobiográfico, as inovações são inevitáveis, o conhecimento é sofisticadamente trabalhado para codificar a subjetividade e também a intersubjetividade. Há uma busca pela construção, há uma mente em 'vigília', atenta às conversas, atenta às 
situações, atenta aos diversos objetos processados pelo aparato do protosself. Essa abstratização dos processos mentais, segundo Damásio, pode ser lido em termos de evolução da espécie:

Se a subjetividade não tivesse surgido, ainda que bastante modesta no início, em seres vivos bem mais simples do que nós, provavelmente a memória e o raciocínio não teriam logrado uma expansão tão prodigiosa, e o caminho evolucionário para a linguagem e a elaborada versão humana de consciência que hoje possuímos não teriam sido abertos (Damásio, 2011: 16).

Outro autor que discute a evolução da mente, porém de uma pespectiva antropológica, é Mithen. Estabelecendo um diálogo entre Damásio (2011) e Mithen $(2002)^{1}$, é possível transportar esse processamento da consciência para a produção cultural do indivíduo. Para este último autor, a metáfora é uma ferramenta do pensamento $^{2}$ que recorre a domínios distintos para sua construção ultrapassando os limites naturais. Nessas transposições, ocorrem associações entre elementos inesperados ou "a geração de uma ideia sobre algo que é tangível" (Mithen, 2002, p. 344). A justificativa para isso é que somente uma mente com fluidez cognitiva poderia transpor limites ${ }^{3}$.

\footnotetext{
${ }^{1}$ Segundo Mithen (2002:321), "o passo crucial na evolução da mente moderna foi a mudança de um modelo do tipo canivete suíço para outro com fluidez cognitiva; ou seja, da mentalidade especializada para a generalizada."

${ }^{2}$ Mithen baseia no filósofo Daniel Dennett (1991),que defende a importância da conversa consigo mesmo, como estilo para a fluidez cognitive, em The intentional stance in theory and practice.

${ }^{3}$ Todos os ancestrais dos homens (australopitecus, homo, neandertais) não teriam condições de produzir fenômenos que demandassem uma cognição fluida, como é o caso da metáfora, que irrompe limites entre categorias ou classes estabelecidas. Do mesmo modo, indivíduos da espécie humana sem a maturação mental (que pressupõe, segundo Damásio, o percorrer do continuum: mente > mente consciente > mente consciente capaz de produzir cultura) não seriam capazes de criar metáforas.
} 
Notemos que a matéria cerebral - biofísica mesmo - é parte do que precisamos para alcançar a capacidade de realização de atividades 'superiores'. Isso se deve ao fato de que essa matéria "está envolvida no processo mental" (Meyer, 2002[1997]:27), e não poderia ser diferente, pois é desse funcionamento integrado que a consciência, o pensamento, a emoção e a percepção manifestam-se também de forma integrada. Não há consciência sem pensamento, não há pensamento sem emoção e não há emoção sem percepção. Toda outra combinação intuída entre esses elementos também é verdadeira. É o que argumenta Meyer, com o qual concordamos:

a matéria cerebral [...] elabora o conjunto da atividade do cérebro, não somente os controles que o cérebro-máquina exerce sobre a vida visceral, mas também as mais nobres funções, que são a consciência, o pensamento, a emoção e a percepção. (Meyer (2002[1997] :13)

E para complicar um pouco essa já complexa atividade, devemos nos lembrar de que a materialidade é afetada por todos esses outros elementos, ou seja, a mente ganha em complexidade no decorrer do tempo, se submetida a vivências, a experiências, a estímulos, enfim.

\subsubsection{Elementos do processamento mental nos estágios dos selves}

Do ponto de vista neurocientífico são elementos do processamento mental: a consciência, o pensamento, a emoção, a memória, a linguagem e a percepção4.

\footnotetext{
${ }^{4}$ Essa falta de consenso deve-se a inclusão ou não de processos que não são conscientes, mas que podem vir a se tornar conscientes, como é o caso de vontade, memória e linguagem.
} 
Trataremos de cada um deles separadamente apenas por questões metodológicas, mas sabemos que, ao tratar de algum deles, naturalmente vamos nos resvalar no conceito do outro.

A consciência é produto do cérebro (enquanto conteúdo) e uma função (enquanto forma). Devido a sua complexidade, Del Nero (1997) metaforicamente a chama de "nó do mundo". Ela se processa numa complexidade de elementos. Ao fecharmos os olhos e pensarmos no fato de em uma menina tomando sorvete, por exemplo, precisamos criar um cenário em nossa mente do qual a protagonista (menina tomando sorvete) faz parte. Esse cenário representa a consciência, pois não visualizamos somente a menina, mas tudo o que está a sua volta. Outro exemplo é quando tomamos algumas decisões e depois dizemos algo como "mas não tinha consciência disso e somente agora percebo...". Essa situação mostra o resgate de um cenário que não era consciente. Muitas vezes também consciência se confunde com conhecimento. Quando alguém diz estar consciente de alguma coisa, quer dizer que tem conhecimento de algo (Del Nero, 1997).

Ainda baseado em Del Nero (1997), a consciência parece atemporal, não espacial. Não ocupa lugar no espaço, não tem a forma de um cubo ou quadrado, não tem cor. Essas qualidades parecem ser suficientes para distânciá-la do cérebro físico, conferindo-Ihe estatuto de fenômeno humano. A consciência tem como propriedade fundamental representar conceitos que não são exatamente idênticos ao mundo e confunde-se com a linguagem. Quando estamos aprendendo o que são cães, olhamos para diversos deles, inclusive desenhados ou caricaturados, e alguém nos informa "isto é um cão" - a forma como aprendemos o conceito de cão é resultado das várias experiências perceptuais e de uma série de correções e 
explicações mediadas pela linguagem de alguém. Por isso, ao fecharmos os olhos, o cão representado em nossa consciência, não é necessariamente um cão do mundo percebido pelos olhos.

Conforme afirma Del Nero (1997) -- e com o qual concordamos acerca do pensamento -- "pensar, por vezes, é tomar decisões em ambientes complexos". Isso ocorre porque o pensamento sofre influência das emoções e da vontade. E por essa razão é uma função singular da mente humana; junto com a linguagem é uma das grandes conquistas da evolução da mente humana, que pode ser consciente ou não, mas, em termos de língua escrita, quanto mais controlado, mais adaptado às regras impostas.

Em se tratando de avaliação escolar, o quesito inteligência sempre entra em questão, por ser definida como a capacidade de estabelecer e testar a maior quantidade possível de relações entre os módulos ${ }^{5}$, e permitir descartar as desinteressantes" (Del Nero,1997: 231). Essa é a propriedade mental mais avaliada no âmbito educacional. Muitos teóricos admitem que é possível instrumentalizar a mente para o desenvolvimento de inteligências específicas.

Para Damásio (2011), a emoção pode ser entendida como humor, sensação e afetividade. Para esta pesquisa focalizamos o humor, do qual a ansiedade faz parte. A ansiedade é um distúrbio emocional, que debilita as funções mentais, em resposta a pressões sociais, morais e econômicas. A ansiedade pode ser considerada uma resposta fisiológica e exacerbada, pois desregula uma série de funções mentais e orgânicas. Assim, não só o rendimento intelectual diminui no

\footnotetext{
${ }^{5}$ Mantivemos o termo "módulo"citado pelo autor, mas devemos considerar que uma fluidez cognitiva por nós assumida rompe com esse modelo de módulos estanques e autônomos.
} 
ansioso, como ocorre uma série de funções físico-corporais: sudorese, taquicardia, palidez e etc. Isso nos permite amparar teoricamente a ocorrência dos famosos "brancos" que o indivíduo tem em momentos de ansiedade, tais como os ocorridos durante os períodos em que há a prova de vestibular ou, mais especificamente, o momento em que é exigida desse candidato a prontidão para a escrita, ou seja, o momento de elaboração da produção textual.

As emoções, segundo Damásio (2011), são automatizadas, não aprendidas e estruturadas pelo genoma em evocações realizadas. Em suas pesquisas, esse autor observou que o mecanismo essencial das emoções é semelhante entre os indivíduos da espécie humana. A seleção de uma forma ou outra, no entanto, pode corresponder a critérios individuais. O que causa medo a um indivíduo pode não causar a outro. O mesmo se dá com a alegria, a ansiedade, a dor, dentre outras emoções. O dito "quem ama o feio bonito lhe parece" é o claro exemplo da sabedoria popular a respeito da regra geral que norteia a escolhahumana em decorrência de suas emoções.

Segundo Damásio, sentimentos diferem de emoções. Essa diferença pode ser melhor compreendida, segundo ele, quando pensamos em patologias, os desvios do que chamamos de normalidade. Sentimentos patológicos seriam a depressão, dor e síndromes de toxicodependência. São dependentes de processos corporais e da mente, portanto.Em consequência, afetam a linguagem e a língua, no momento da produção, produzindo sinais nos vários níveis ${ }^{6}$ de codificação.

\footnotetext{
6 Aqui, níveis referem-se aos vários subsistemas linguísticos (fonética, morfologia, sintaxe e pragmática), mas também a vários sinais presentes na fisiologia e na prosódia, por exemplo.
} 
A emoção toma como palco de reação o corpo. Então, quando um indivíduo tem uma emoção negativa, por exemplo a tristeza, outros pensamentos negativos são evocados. Já uma emoção positiva provocará o oposto. Pesquisas, como as de Kleinman, Lafer e Caetano (2008) têm demonstrado que pessoas bipolares, num momento depressivo, tendem a enxergar a tristeza em semblantes que não se encontram verdadeiramente tristes.

Ainda segundo o autor, também os sentimentos provocam muitas consequências no indivíduo, dentre as quais citam-se as seguintes: orientam comportamentos, ajudam a aprendizagem, trazem vantagens para a espécie. Desse modo, impactam qualitativamente a linguagem e a língua, ou seja, podem impactar a qualidade da produção e da materialização linguística. O estado resiliente dos sentimentos é enorme, pois sobrevivem a danos cerebrais.

Transpondo essa questão para a situação de produção de texto, em situação de avaliação como é o caso das redações sob análise, podemos pensar no impacto que emoções e dos sentimentos pode ser a solução ou problema. Um indivíduo que está com emoções polarizadas negativamente, por exemplo, pode ter sua prontidão afetada, assim como a organização e logicidade das ideias expostas. O que se supõe, então, é que o rendimento desse aluno pode ser reduzido, pois essa emoção impacta o raciocínio. Em contrapartida, se as emoções estiverem polarizadas positivamente, também o rendimento pode ser impactado, e não necessariamente para um resultado positivo, pois as emoções podem tornar opacas as relações legítimas na ordenação e correlação de argumentos. 
Essa proposta de Damásio entra em conflito com a de Del Nero $(1997)^{7}$, que situa a depressão nos fenômenos de emoção e não nos de sentimento. A explicação para isso é que, até bem pouco tempo, sentimento e emoção não eram claramente distinguidos. Com as pesquisas de Damásio e de seu grupo na última década, inclusive mobilizando recursos de imageamento cerebral, demonstrou-se que há, no cérebro, um lugar para emoções e outro para sentimentos ${ }^{8}$.

Mithen (2002 [1996]) $)^{9}$ explica que a memória do "procedimento" refere-se ao conhecimento que pode ser expresso pela demonstração. Esse tipo de memória opõe-se à memória da proposição, dividida em dois subtipos: a episódica (lembranças de acontecimentos e feitos pessoais) e a semântica (conhecimento de mundo independentemente da identidade e passado do indivíduo). Segundo o autor, somente a memória semântica é exclusiva dos humanos modernos, pois decorre da "invasão da inteligência social pela informação não-social" (id., p. 319). Essa memória, sendo incorporada pelos módulos mentais, antes voltados para o protosself, para manter um paralelo com as descobertas de Damásio, tornou-se disponível à consciência coletiva via compartilhamento social. Diante das postulações de Damásio, ressaltamos, em um viés linguístico, a proposta de Dik que sustenta-se no argumento de que o usuário da língua é parte do sistema integrado à língua. Dessa forma, o discurso do falante "[...] é interpretado adequadamente se se levar em conta unicamente o conteúdo intrínseco da cadeia linguística; outros

\footnotetext{
${ }^{7}$ Del Nero (1997) identifica a emoção com os eventos de humor, afeto e sensação.

${ }^{8}$ Ainda assim, deve-se considerar a plasticidade cerebral como uma das grandes ferramentas da fluidez mental.

${ }^{9}$ Para esse autor, ainda é vigente a ideia de que "módulos" constituem a mente humana, no entanto, esses ganhariam, em estágios mais avançados da evolução humana, fluidez.
} 
tipos de conhecimento são necessários ao sucesso da interação verbal. Dik agrupa em dois tipos esses conhecimentos: a) conhecimento de longo-termo (constitui-se por meio dos componentes lexical e gramatical); e b) conhecimento de curto-termo, ( deriva de eventos comunicativos e situacionais).

Esses conhecimentos dialogam com as memórias descritas por Damásio, j]a que o conhecimento de longo termo representa a memória de longo prazo e o conhecimento de curto termo, a memória de curto prazo. Ambas dependem da recorrência frequencial de eventos, ou seja, do experienciamento rotineiro de situações. Por isso é que Dik subdivide-o em dois tipos: situacional (constitui o conhecimento sobre o centro dêitico do evento comunicativo) e textual (que permite que o falante reconheça a referenciação textual, os estados-de-coisas a partir das regras e princípios que governam o mundo real e mundos possíveis no texto). Logo, sem perder de vista o dinamismo cooperativo, observa-se que as atividades interativas, que se traduzem num mútuo trabalho de construção interpretativa da informação pelos interlocutores envolvidos, são fonte para a gramaticalização de intenções, tal como prevê o modelo funcionalista de Dik (1989):

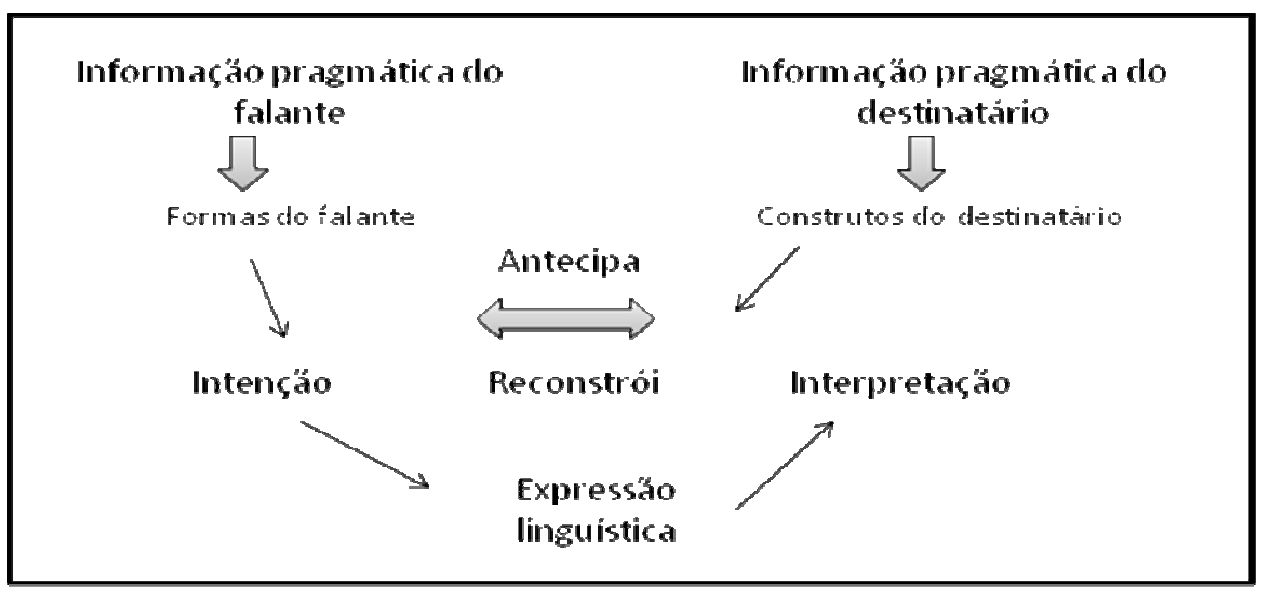

Quadro 2: Esquema do modelo de interação verbal de Dik 
As memórias seriam para Damásio o cimento do conhecimento. Elas atuariam para que as relações fossem adequamente estabelecidas, inclusive manifestando a plasticidade cerebral, verificável em imageamentos. É esse autor, que, investigando a maturação do cérebro em termos de consciência, numa perspectiva filogênica, porém recuperando evidências da sincronia, apresenta uma abordagem mais refinada e mais em sintonia com as verificações por equipamentos de imagem em laboratório multidisciplinar voltado ao estudo da cognição.

Nessa abordagem neurocientífica de evolução do self, Damásio e seus colaboradores consideram que o self autobiográfico é o lugar da memória consciente. Todo indivíduo vivencia, experiencia, mas nem sempre tem capacidade ou vontade para fazer uso consciente desse material considerado memória.

A finalidade guia essa vontade, mas é necessária também a destreza, o saber fazer quando se adentram os espaços de aprendizados escolares. Adiaremos essa entrada aos ambientes escolares para, primeiro, tratar do que Damásio vislumbra como o roteiro para essa mente mais madura. Essa maturidade escalar, também é necessário esclarecer, depende necessariamente da "sedimentação gradual" e da reelaboração constante da memória. Vários dos elementos do processamento mental participam disso, dentre os quais as emoções e os sentimentos.

Ainda no processo de compreender os elementos do processamento mental, foquemos nossa atenção agora na linguagem, que é um dos grandes artífices da mente e da cultura humana, porque se trata, no caso da expressão linguística, de um conjunto de peças que se articulam e que dependem de um sistema com capacidade de reagir ao meio. O cérebro humano produz infinitas sentenças a partir 
de um conjunto finito de regras e símbolos, pois codificamos uma mesma informação de variadas maneiras. Essa ideia não somente entra em consonância com modelos formalistas hard, mas também com o que de mais precioso existe no funcionalismo: a manutenção de funções a despeito da forma ou vice-versa. Assim, a dinâmica sistêmica preside operações fundamentais para a interação dos indivíduos. É o que defende Del Nero, numa perspectiva da neurociência:

A linguagem é uma função do cérebro humano que, do ponto de vista de sua história cerebral, envolve regiões preferencialmente aptas para ela e uma dinâmica de interação com fatos linguísticos externos que acabam por fazer com que sua operação plena seja departamento virtual, mais ou menos fixo. Do ponto de vista de sua estrutura, é composta de um conjunto de regras de construção de sentenças (sintaxe) e de um conjunto de significados, interpretações e objetos capazes de ter existência real ou imaginária - por exemplo, "mesas", átomos", " justiça" e "centauros" (semântica). Há ainda um fator de contexto que influencia na compreensão de certas expressões linguísticas, chamado pragmática. Imagine que falo a palavra "porco" num açougue ou num campo de futebol. Em cada local, graças à interpretação contextual, significarão mensagens diferentes (DEL NERO, 2002:309-310).

O self autobiográfico, a instância de consciência mais alta do indivíduo, age, como já afirmamos, com base nos conhecimentos acumulados na memória e também em registros possibilitados pela criação humana, como a pedra, a argila, o papiro, ou papel e nos HDs. Esse percurso evolutivo do suporte também permite reconhecer a busca pela preservação de informações e conhecimentos, sem sobrecarregar o 'HD' humano, o cérebro. 
A linguagem continua sendo um elemento importante de integração, de aprendizagem e de saltos evolutivos via descobertas e incorporação de tecnologias. Além disso, tendo onde guardar tanta informação, sem necessariamente ter de utilizar esse cérebro como recipiente, ficou mais fácil liberá-lo para o pensar, para a reflexão e para outras atividades tão humanas, como a arte, a religião, o mito e outras tantas formas de regular o comportamento social ${ }^{10}$.

Cabe, neste momento, questionar se seria possível afirmar que a linguagem assim como a língua denunciam graus de consciência? Hipotetizamos que, na língua escrita, na situação de exame vestibular, foco de interesse nesta tese, isso ocorra. Ainda assim, restam algumas questões: nesse estado de vigília - com alto grau de consciência - do momento da produção textual para o vestibular, haveria mecanismos linguísticos capazes de denunciar essa mente voltada para a produção de cultura, ou seja, a mente num estágio de self autobiográfico? Haveria um espaço ideal para alcançar esse estágio de imediato? A resposta dada tem sido afirmativa. Cabe-nos referendá-la cientificamente via investida nesse espaço que, em nossa pesquisa, se identifica como o primeiro parágrafo do texto. Esse primeiro espaço deteria, pelo menos no momento de elaboração, resquícios ou contrapartes linguísticas da tensão emocional que tende a afetar o pensamento num momento em que a percepção deveria funcionar $100 \%$ para a captação da proposta temática. Sem sombra de dúvidas, a língua, via caracterização léxico-morfossintática será o mecanismo mais transparente para a identificação do estágio de consciência desse indivíduo, como demonstraremos adiante.

\footnotetext{
${ }^{10}$ Damásio (2011:353) cita a moralidade, os sistemas de justiça, a economia, a política, a ciência e a tecnologia.
} 
Enfim, o processo mental denominado percepção é a via de entrada e de processamento de informações. Numa situação cotidiana face a face, a mente se manifesta, por meio de palavras e de atos, motivações, enquanto a mente do interlocutor, também em estado de vigília (a situação ideal) agiria para a compreensão da informação num espaço conjunto de atenção constituído, não apenas decodificando ${ }^{11}$ as palavras e gestos, mas construindo um pareamento forma-função e sentido típico da comunicação.

De um ponto de vista do interlocutor inicialmente ouvinte, a captação ou percepção da mensagem e das informações codificadas, incluindo-se aí a acessibilidade que se imagina prevista pelo interlocutor inicialmente emissor, vêm pela ação (ou motricidade), pela fala, pelo gesto, pela musicalidade e pela ênfase e pela prosódia. Só esses elementos também não dão conta de tudo o que vem a se constituir interação. Entram nesse espaço conjunto de atenção todas as informações advindas dos músculos corporais, pois todas elas agem para que a comunicação alcance o objetivo de ser eficiente. A linguagem verbal e também a corporal expressam, na medida do possível, o mundo mental. Ocorre que, na modalidade escrita, isso tudo é reconstruído ao sabor da (inter)subjetividade.

E por que fazemos isso? A resposta é bem simples: fazemos melhor o que fazemos mais e rotineiramente principalmente porque ganhamos destreza e expertise. Na filogênese, essa ideia ganha eco. Se os australopitecus já codificavam intenções derivadas de emoções básicas. Não é de se estranhar que essas habilidades foram ganhando em refinamento nas ações comunicativas e motrizes,

\footnotetext{
${ }^{11}$ Temos consciência de que o termo decodificação não soa adequado ao modelo funcionalista, mas o mantivemos aqui para representar melhor as ideias do autor.
} 
provocando também o aumento do cérebro. Só com a fluidez cognitiva, ou seja, com a mobilização de conhecimentos diferentes, mas já adquiridos, para resolver problemas novos, é que esse cérebro pesado ganhou em velocidade e evolução. Como supor agora que tanta energia gasta em favor dessa nova configuração seria descartada e inutilizada pelos coespecíficos e descendentes nas novas experiências e problemas vivenciados? É o que discute Cabral (2005) ao tratar do processamento na produção linguística pelo interlocutor (recepção).

Esse autor, afirma que a volição, a intencionalidade e a motivação tanto conforma o momento da recepção quanto o da emissão, ambos guiados por intenções (aspectos pragmáticos) "de convencer, de informar, de mudar o comportamento de alguém, de produzir um efeito estético, de contornar as dificuldades de uma memória capenga" (id., p. 217). As estratégias adotadas durante esse processamento dinâmico de emissão-recepção contínuo guiam-se pela decisão que menos energia demandar, ou seja, por esquemas produtivos. Esses esquemas são comuns em todos os níveis de produção (fonológico, morfológico, sintático e pragmático) e, como propiciam economia de energia, são mobilizados para novas intenções ou para outros planos de ação comunicativa.

\subsubsection{A evolução humana e o desenvolvimento da linguagem}

Uma boa forma de começar a tratar do tema é convidar Pinker para um diálogo. Em sua obra 'Do que é feito o pensamento?”, ele se pergunta de onde viriam as palavras. Argumenta que transmitir um sentido a outras gerações pode equivaler, numa perspectiva da recepção, a uma ação de decorar um uso idiossincrático. Muitas vezes, não conseguimos compreender por que as partes de 
uma palavra não equivalem de jeito algum ao sentido habitual de sua forma completa.

Nem tudo é óbvio, embora tenhamos construída entre nossos contemporâneos a falsa ideia de que isso seria uma verdade. Talvez as onomatopeias correspondessem a isso porque, quando o ser humano diz "au au", facilmente se chega ao sentido de que alguém está imitando o som emitido por um cachorro. No entanto, há em jogo o aspecto cultural. Talvez um alemão não entendesse do mesmo modo.

Em se tratando de instâncias mais abstratas da língua, como é a sintaxe, menos ainda se espera que as significações sejam transparentes. Então, ao redigir, num artigo científico, que "buscamos apresentar um estudo das construções ditransitivas", a primeira e mais evidente informação é a colocada à direita na sentença, qual seja, a informação posverbal, que apresenta a informação de que estudaremos as construções verbais que se completam com objeto direto e também indireto. Há, contudo, uma informação codificada ali que, embora seja primordial para alcançar a intenção do escrevente, não ganhou foco na apresentação, qual seja, o emprego do verbo buscar (Barroso, 2008) para denunciar um certo receio de que talvez, por algum azar de percurso, esse objetivo não seja alcançado, ou que o autor teve a intenção de se mostrar modesto. O mesmo se dá com as codificações de intenções em formulações ainda mais abstratas, como é o caso de textos escritos. Vicente (2009) evidenciou que o indivíduo emprega a construção afinal para sinalizar sua intenção de marcar o lugar último da reflexão, a última ideia a ser exposta. Como construção polifuncional, afinal pode ser também um marcador 
discursivo que sinaliza a existência de uma reflexão em curso sobre um tema ou uma pessoa. Ao empregá-lo, o autor do texto expõe seu questionamento a partir de informações que foram pensadas, embora não se tenha feito uma pressuposição. Servimo-nos da sintaxe para, à esquerda da sentença, construir o espaço do sujeito, suas intenções e o que julga ser conhecimento compartilhado. Quanto à direita, reservamos para o que é foco, pressupostamente novidade para o interlocutor. A sentença como espaço de intenções, ou melhor, de explicitação de intenções do falante-escrevente, é um campo de interesse dos funcionalistas, abordagem teórica em que este trabalho se enquadra. As construções e a forma linguística, codificadas via sintaxe prioritariamente, constituem-se espaço de representação simbólica dos conhecimentos filogênicos, também capturados em instanciações das fases ontogênicas (TOMASELLO,2003 [2000]).

Segundo Taylor (2002):

\begin{abstract}
A língua dever ser caracterizada por uma unidade linguística de estrutura inventariada. A unidade linguística abrange unidades fonológicas, semânticas e simbólicas. O inventário não é somente muito extenso, é também estruturado naquela unidade que estão inter-relatadas em estruturas complexas e intricadas. ${ }^{12}$ (Taylor, 2002: 123, tradução nossa).
\end{abstract}

Ainda para este autor as construções têm duas funções:

\footnotetext{
${ }^{12}$.A language may be characterized as a structured inventory of linguistic units. The linguistic units comprise phonological units, semantic units, and symbolic units. The inventory is not only very large, it is also structure, in that units are interrelated in complex and intricate ways (Taylor, 2002: 123).
} 
Primeiro, função de sancionar: os esquemas seguem expressões que estão construídas em conformidade com esquemas que são rápida e seguramente categorizados e estruturados (são estruturas aceitas na língua). Segundo, função de facilitar: os esquemas facilitam a criação rápida e enfraquecedora de um número indefinido de novas expressões, em conformidade com os esquemas específicos $^{13}$ (Taylor, 2002: 233, tradução nossa).

Como toda estrutura se compõe de conjunto de palavras, todo conjunto de palavras se reveste de contextos que não são usuais na língua. . É o caso da estrutura "numa outra esfera da vida (...) existe" que combina palavras em configurações maiores, não devendo ser tratadas como componentes sintáticos especiais da gramática, mas como construções (TAYLOR, 2002). Desta forma, organiza-se na construção (ECircun + Vbt = E), na qual ECircun está para Estrutura Circunstancial e Vbt está para Verbo de baixa transitividade que, juntos, na estrutura sintagmática resultam em Espaço.

Os princípios de construção em mudança utilizam-se do fato de que $\mathrm{CxG}^{14}$ trata conhecimento gramatical como o resultado de uma convencionalização gradual dos padrões de entendimento, em que a estrutura morfossemântica, função sintática, função comunicativa e

\footnotetext{
${ }^{13}$ Constructional schemas have two principal functions. First, constructional schemas have a sanctioning function. They allow expressions which are constructed in conformity with the schemas to be rapidly and reliably categorized and interpreted (and to be judged as fully acceptable in the language). Secondly, the schemas have an enabling function. They facilitate the rapid and effortless creation of an indefinite number of new expressions, in conformity with the specifications of the schema (Taylor, 2002: 233).

${ }^{14}$ Gramaticalização de construções.
} 
lexical formam um todo integrado, aos quais a mudança lingüística pode envolver ${ }^{15}$ (Fried, 2013).

Como vimos até aqui, a mudança linguística manifesta-se também por analogia, que alinha um padrão de uso a um novo contexto. Sendo assim, a construção linguística é efeito de um processamento cognitivo. Essa é a razão por que trataremos desse tema mais detidamente na seca seguinte, baseados em Bybee (2010).

\subsubsection{O processamento cognitivo linguístico}

Bybee (2010) apresenta os processos cognitivos a que subjaz a formação das construções. Ou seja, seu objeto de pesquisa se dá no processamento linguístico e como esses processos afetam a representação das palavras na mente, resultando em mudanças linguísticas ao longo do tempo. Desta forma, é possível mostrar como esses processos cognitivos moldam a gramática da língua. Em seu estudo, uma das principais considerações diz respeito ao papel da frequência de uso na representação mental e, consequentemente, na mudança linguística.

Pelo fato de as línguas, ao mesmo tempo, exibirem regularidade e variação, Bybee (2010) postula que uma teoria linguística poderia focar os processos dinâmicos que criam as línguas e fazem delas sistemas adaptativos complexos, os quais exibem gradualidade no processo de evolução, via variação e mudança, esta

\footnotetext{
15 The principles of constructional change capitalize on the fact that CxG treats grammatical knowledge as the result of a gradual conventionalization of patterns of understanding, in which morpho-semantic structure, syntactic function, communicative function, and lexical meaning form an integrated whole, and linguistic change can involve any subset of these aspects.
} 
última dificulta a distinção das categorias linguísticas, ainda que exista em todos os níveis linguísticos e que seja essencial durante o processamento. Essa é mais uma evidência de que a língua é afetada pelo uso e o sistema cognitivo, pela experiência. A partir dessa concepção é possível analisar como os processos cognitivos de domínio geral podem dar origem aos fenômenos estruturais observados na gramática das línguas.

Cumpre ressaltar a pertinência do conceito de "construção". Conforme definido por Croft (2001), trata-se de uma união entre forma e sentido que implica estrutura sequencial e pode incluir posições fixas e abertas. Segundo Bybee (2010), como as construções apresentam essa união, consequentemente sintaxe e semântica não são módulos separados, bem como os processos que geram a estrutura linguística não são específicos da linguagem e, sim, aplicados a outros domínios cognitivos (domínios gerais). Alguns desses domínios manifestam-se na linguagem, ou como efeito (chunking e categorização), ou como processo desencadeador do uso (memória rica, analogia, e associação transmodal). .

No caso do chunking, ocorre quando duas ou mais palavras são usadas juntas, elas também desenvolvem relação sequencial, nos termos de Bybee. A força das relações sequenciais é determinada pela frequência com que cada uma das palavras aparecem juntas (repetição). Logo, a frequência de uso das sequências impactam as propriedades fonéticas, morfossintáticas e semânticas. Os chunkings podem ter graus de autonomia distintos e Podem também replicar-se (dois pequenos chunks que coocorrem com algum grau frequencial podem desencadear um grande chunk). 
No que tange à memória rica, podemos dizer que se trata de um armazenamento de exemplos. Essa declaração vincula-se ao pensamento de Langacker (1987), que defende que é necessário acumular na memória um conjunto de exemplos para formar uma generalização, os quais não são necessariamente descartados. Bybee (2010) supõe que redundância e variação são estocados na memória, assim revê o papel da imitação e afirma que essa habilidade, juntamente com outras, contribui para o funcionamento das línguas. No campo da fonologia, mostra que cada dado tem impacto na memória, pois mesmo a pronúncia do adulto pode mudar com o tempo, ainda que sutil e mais vagarosamente. Na morfologia, as relações surgem a partir da formação de palavras devido a sua semelhança fonética e semântica. Por exemplo, capable categoriza-se como um adjetivo por ter um sufixo formador de adjetivos, -able, como em readable e unbelievable, embora cap- não signifique nada. Essa propriedade de representação de memória rica é importante para explicar como palavras, sequências de palavras e construções acumulam propriedades específicas quando são usadas em um contexto.

Os padrões são extraídos de diferentes contextos e por meio de itens lexicais diferentes. [...] As regularidades não têm de ser registradas com itens lexicais específicos; então, os itens lexicais contém somente informação idiossincrática ${ }^{16}$.(BYBEE, 2010, p.15, tradução nossa)

A despeito de certos cuidados acerca da necessidade de mais especificados itens lexicais (Jackendoff 1975), a prática básica de

\footnotetext{
${ }^{16}$ There are several motivations in these frameworks for accepting this position. [...] It follows, then, that regularities do not have to be registered with specific lexical items ; thus the lexical items contain only the idiosyncratic information.
} 
remover informação predizível do que está armazenado continua ${ }^{17}$ (BYBEE, 2010, p.15, tradução nossa).

Cadeias de palavras podem ser analisadas numa rede de relações. Enquanto um idioma tal como pull strings tem seu próprio sentido metafórico, não obstante ele é associado com as palavras pull e strings como palavras independentes ${ }^{18}$ [...] (BYBEE, 2010, p. 25, tradução nossa).

No nível sintático, cadeias de palavras podem ser analisadas numa rede de relações. Por exemplo, a expressão idiomática pull strings tem sentido metafórico, não obstante é associada às palavras independentes pull e strings. Já as construções são mais complexas, pois são parcialmente esquemáticas e podem ser acessadas por extensão analógica ou por criação de novas construções. Expressões idiomáticas e unidades pré-fabricadas são exemplos específicos de construções. Para Bybee (2010), a relação sequencial desenvolvida quando duas ou mais palavras são usadas frequentemente juntas constrõem estruturas hierarquicamente organizadas para armazenamento na memória, isto é, chunks menores dentro de maiores. Esses chunks menores são repetidos com maior frequência e isso leva à formação de construções, sequências formuladas ou préfabricadas: Em contrapartida, quanto maior for o chunk (a unidade formada por vários vocábulos), menor a frequência de ocorrência. A estrutura pré-fabricada mais recorrente é a categoria Espaço que se organiza em Preposição (em) + palavra que

\footnotetext{
${ }^{17}$ Despite certain warnings about the need for a more highly specified lexicon, the basic practice of removing predictable information from storage has continued.

${ }^{18}$ Strings of words can be analysed in a network of relations. While an idiom such as pull strings has it own metaphorical meaning, it is nevertheless associated with the words pull and strings an independent words.
} 
marca o tempo (atual, contemporâneo, épocas, nos dias de hoje) e/ou Lugar + Verbo de baixa transitividade $(\mathrm{Vbt})=$ Espaço. Logo, podemos dizer que a estrutura interna do chunk é (Em+Tempo e/ou Lugar + Vbt).

Existem chunks fracos e fortes formando, assim, um continuum: desde palavras que foram usadas juntas somente uma vez, nesse caso suas partes internas são mais fortes do que o todo, até as mais frequentes, que são mais facilmente acessadas. A estrutura interna do chunk é baseada em associações entre estruturas pré-fabricadas e outras ocorrências das palavras que aparecem nela.

Tendo em vista que o espaço para a construção da (inter)subjetividade ganha força à margem esquerda da sentença, hipotetizamos que toda vez que o chunk espacial está mais à esquerda na sentença, menos chunks serão associados a ele e mais recorrente o chunk espacial será. Contrariamente, quanto mais o chunk espacial estiver localizado à direita mais associado a outros chunks ele estará e menos recorrente será. Em termos da construção de uma tese forte, o espaço à esquerda é assim mais fortalecido - e seguro - do que à direita, onde demandará mais informações devido a ser mais fraco. É possível, assim, representar esse grau de fortalecimento da tese com um continuum, que será apresentado no capítulo IV

Para analisar a mudança gradual de um item lexical ou cadeia sequencial, Bybee (2010) propõe os critérios de composicionalidade e analisabilidade. O primeiro se refere ao grau de previsibilidade do significado do todo a partir do significado das partes (aspecto semântico). $O$ segundo se refere ao reconhecimento da contribuição de cada componente no contexto de uso (aspectos 
morfossintático e discursivo-pragmático). Esses critérios são independentes, pois há casos em que a composicionalidade é perdida, mas a analisabilidade se mantém.

Um processo relevante para se analisar construções é o inferencial. Segundo Bybee (2010), elas são dependentes do contexto, que pode tornar-se parte do significado da expressão ou construção, levando o seu uso a novos contextos. Isso sugere que não há uma divisão clara entre os sentidos que emergem do contexto e os inerentes ao item lexical ou à construção.

A analogia, outro aspecto tratado por Bybee, também chamada de similaridade, é um processo de domínio geral em que há semelhanças entre dois domínios diferentes. Ocorre quando o uso de um novo item surge em um padrão/construção já existente. Entretanto, a probabilidade e aceitabilidade de um novo item é gradual e baseia-se na semelhança fonológica ou semântica com formas ou construções existentes. Ademais, o uso de um novo item em uma construção requer conhecimento relacional e ajuste estrutural, requisitos para a analogia. Isso mostra que nossas escolhas vocabulares não são livres e sim determinadas por chunks maiores ou estruturas pré-fabricadas que servem de base para a analogia. As estruturas pré-fabricadas embora estabelecidas pela repetição no uso, não precisam ser altamente frequentes.

Já a categorização, ainda segundo a mesma autora, inclui aspectos pragmáticos, pois os itens lexicais presentes na construção contribuem para o seu sentido e ajudam a determinar sua função e distribuição no discurso. A semelhança e a frequência são dois critérios importantes para determinar os casos prototípicos. 
Os processos cognitivos se aplicam à mudança linguística, especialmente no que se refere a casos de gramaticalização e à criação de novas construções em geral. Acerca da gramaticalização de acordo com Bybee (2010) é importante se considerar que o processo acontece dentro de uma construção particular e que, por meio desse processo, novas construções são formadas. Portanto, a gramaticalização ocorre no uso da língua e envolve um processo em que uma instância particular de uma construção se torna autônoma em relação às demais instâncias.

O processo de domínio-geral chunking, por exemplo, evidencia que unidades relevantes semanticamente entre si tenderão a aparecer juntas. A estrutura constituinte depende também da categorização, outro processo cognitivo, que resulta em conexões de rede que sustentam a analisabilidade. Assim, é possível entender uma sequência de palavras que, frequentemente aparecem juntas, adquire uma representação própria, a qual informa sobre seus contextos de uso, seus sentidos e inferências. Desta forma,, o grau de reconhecimento dessa sequência, como uma unidade autônoma, depende da existência ou não de analisabilidade de suas partes em relação ao todo.

Decorrente da perda da analisabilidade, surge o processo de decategorização, um importante indicador de gramaticalização de um nome ou de um verbo dentro de uma construção. Nesse sentido, a autora compreende que, em exemplos de preposições complexas (como em in spite of), os nomes que delas fazem parte acabam perdendo os atributos da categoria gramatical. As construções novas são decorrentes da reanálise gradual, que apaga as fronteiras entre as palavras. 
Analisemos alguns exemplos que ilustram como nos apropriaremos desses conceitos para lidar com a construção objeto de interesse nesta tese:

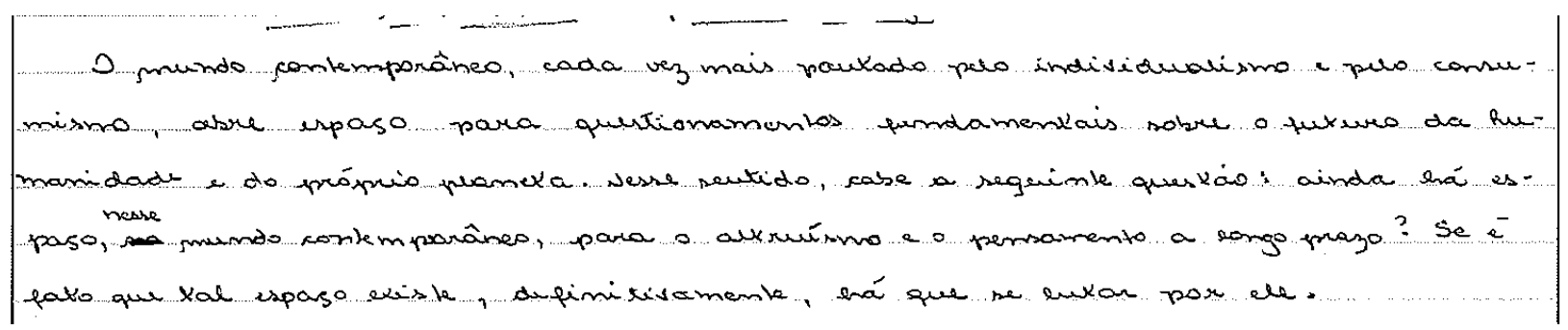

[(1) $1239442011 \mathrm{M} 13]$

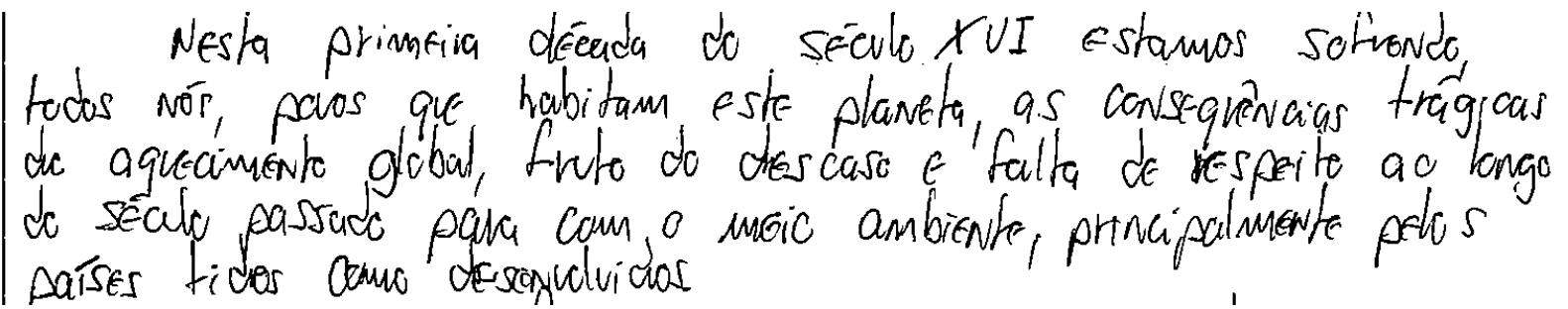

[(2) 5005272009 P21]

Na primeira redação (1), a expressão "o mundo contemporâneo" em contraste com a expressão "Nesta primeira década do século XVI", da segunda redação (2), revela-se mais dependente de um centro dêitico. O espaço de ambos, embora não se apresente nessa primeira expressão, pode ser recuperado nas informações seguintes que compõem a sentença. Assim, quando o candidato faz a sua escolha lexical, por exemplo na redação (2), para determinar o tempo ao lado da preposição "em", que apresenta traços semânticos temporais e locativos, sinaliza que não quer simplesmente fazer uma apresentação temporal. Ele manifesta, com essa decisão, a necessidade de reforçar a expressão de tempo com uma preposição que, além de tempo, também marcará lugar. Isso reforça a ideia de que toda vez que estamos 
tratando de algo que tem marca locativa e temporal, o resultado produz uma nova categorização cognitiva mais abstrata, a categoria espacial.

Numa abordagem metodológica apropriada ao modelo teórico funcionalista em interação com pressupostos da linguística baseada no uso, recorreremos a conceitos de informatividade, de iconicidade, de marcação e de planos discursivos no que tange a fundo e figura.

\subsection{Funcionalismo e cognição: da ideia à codificação sintática}

Nesta seção, apresentamos as bases de algumas teorias e pressupostos teóricos que foram estudados durante o curso de pós-graduação, em discussões e encontros do grupo de pesquisa Linguagem e Cognição - LINC/USP, os quais puderam contribuir para construir hipóteses, para delimitar dados, para explanar quadros descritivos e para encontrar o melhor caminho metodológico neste trabalho.

\subsubsection{Compreendendo a língua}

A definição de língua é importante para que possamos compreender o ponto de partida de cada autor a respeito da mudança linguística. Com base em Neves (2002), a língua é um sistema semântico, logo manifesta a produção de sentidos, incluindo nessa designação, conforme Halliday (1985), a inter-relação dos domínios: léxico e gramática. Já, Castilho (2006) compreende a língua como um sistema funcional de base pré-verbal. São perspectivas diferentes se analisadas do ponto 
de partida de cada autor. Neves constitui um sistema semântico como prioritário para todo o revestimento morfossintático, fonético e pragmático. Diremos mesmo que estes estão a serviço daquele. Castilho sinaliza um sistema que se manifesta antes mesmo de que a semântica se exale, porque é cognitivo prioritariamente. Essas diferenças observadas, no entanto, são complementares.

Língua é interação, língua é dinâmica social, mas, antecede seu estatuto social e interativo, sua natureza primeira de ser uma forma de cognição manifestada antes mesmo de serem proferidas as palavras; ela pode ter sua evolução acompanhada no processo de aquisição da linguagem pela criança desde a fase mais tenra até a vida adulta. Se a criança desenvolve, aos nove meses, a habilidade de replicar comportamentos é porque ela está amadurecendo em sua função de observadora de si e do mundo circundante (LIMA-HERNANDES, 2010). Para que replique um comportamento, ela precisará prestar atenção, e o controle da atenção vai, assim, sendo maturado. Se mais adiante conseguir formular uma hofófrase, é porque selecionou termos importantes de uma situação interativa que se foi repetindo ao longo de seu crescimento ou de suas atividades cotidianas (LIMAHERNANDES, 2010).

Com isso, estamos assumindo que parte do esteio teórico desta tese advém dos postulados cognitivistas, que, como Tomasello (2003[2000]), assumem a língua como uma forma de cognição. Desde que é adquirida, a língua reflete um exercício contínuo de aprimoramento de capacidades cognitivas. Por meio de uma palavra dita somada a conhecimentos de hábitos, podem-se compreender a informação global e os objetivos do interlocutor, por exemplo. Assim, a língua é um sistema organizador de objetivos e intentos comunicativos, via empacotamento cognitivo. $\mathrm{E}$ a 
sintaxe, como sistema operacionador, é a forma de codificação desses intentos numa esfera linguística. Nessa perspectiva, pode-se dizer que a mais importante distinção que um falante faz, no plano cognitivo, é aquela entre eventos e participantes; e, no plano da língua, os pares distintores mais importantes são: (i) tópico discursivo (sobre o que se fala) e foco discursivo (o que se fala sobre algo); e (ii) coisa e processo (LIMA-HERNANDES, 2010).

Para dar conta de uma concepção ampla como essa sobre a língua, entendemos que alguns campos teóricos podem contribuir: a teoria da gramaticalização, que assume um diálogo com a teoria funcionalista; e a teoria cognitivista, que permitirá reflexões sobre mecanismos perceptivos humanos. Essas searas canalizarão as ideias desenvolvidas nesta tese, porque os efeitos que causarão nas reflexões sobre o tema impactarão os tambémintegrados no sistema complexo e dinâmico da língua.

Parte-se, agora, da concepção de que sintaxe é um meio de codificar uma solução linguística para dar conta de objetivos e intentos. A despeito de parecer algo totalmente volitivo, na verdade, atende a soluções historicamente construídas e produzidas sistematicamente para a solução de problemas similares. Ocorre que essa estruturação, sempre em processo, pode sofrer mudanças na forma, motivadas por forças interativas, tais como a pressuposição de compartilhamento de informações entre os falantes. Assim, a mudança pode ser decorrente de estratégias de organização da informação empregadas pelos falantes no momento da interação discursiva (MARTELOTTA \& AREAS, 2003:23).

Em atendimento a esse pressuposto básico, Neves (2004) define a gramática funcional como um modelo que propicia repensar a organização gramatical das 
línguas naturais de modo integrado a uma teoria global da interação social. Segundo essa autora, a gramática funcional leva em consideração o uso das expressões linguísticas na interação verbal, o que supõe de antemão uma relação pragmática do componente sintático-semântico e a relação entre eles.

Lima-Hernandes (2005), analisando os pressupostos de Dik (1997), apresenta sua aderência teórica à corrente funcionalista assentando a razão na forma integrada de descrição e de explanação das línguas. Essa integração equivale à combinação de aspectos pragmáticos e psicológicos, os quais favorecem descrições holísticas sobre o entorno comunicativo e permitem recorrer às motivações e aos objetivos da interação verbal, que são questões centrais para o analista que visa às correlações com os processos mentais envolvidos na interpretação e produção das expressões.

Algumas ideias podem ser consideradas nas perspectivas de cada um desses autores como chave na compreensão do trabalho funcionalista, tal como aqui o faremos: contexto, interação, integração sistêmica e processos mentais. Essas concepções estão presentes, em maior ou menor grau, de modo mais ou menos explícito, em todas as pesquisas que se vinculam ao arcabouço funcionalista.

Durante 0 relato da pesquisa nesta tese, as estruturas introdutórias demandarão uma análise revestida do contexto de produção, pois somente assim pode-se resgatar o peso das intenções comunicativas do produtor do texto e das expectativas que alimenta em relação ao seu interlocutor previsto. Também procedemos a uma análise que não perde de vista que subsistemas devam ser considerados de modo integrado, pois qualquer alteração em um pode culminar com um efeito diferente do esperado no outro. 


\subsubsection{O recorte funcionalista sob a perspectiva cognitiva}

As pesquisas que procuram revelar os mistérios da aprendizagem cultural em outras espécies que não a humana não são recentes. Etólogos e psicólogos de várias partes do mundo procuram, na observação do comportamento dos outros grandes primatas, encontrar indícios que justifiquem o que torna os humanos seres tão diferentes cognitivamente, apesar de tão próximos geneticamente dos outros grandes primatas.

Alguns dos estudos mais significativos no sentido de oferecer caminhos para explicar essa diferença cognitiva são aqueles cujos resultados ajudam a fazer inferências a respeito da distinção na capacidade cognitiva entre as espécies de grandes primatas, daí selecionar para discussão os que se referem à atenção conjunta, à teoria da mente e, consequentemente, à interação comunicativa. Estes estudos vêm servindo como base para diversas pesquisas interdisciplinares, tornando-se alvo de estudo de biólogos, psicólogos, filósofos e linguistas, todos embasados por uma teoria cognitivista que se mostra preocupada em descobrir os mistérios da mente humana e de sua capacidade linguística.

A atenção conjunta é aparentemente uma capacidade-chave para que a evolução da espécie humana se cumpra. No período em que o bebê humano inicia seu processo de desenvolvimento dessa capacidade, as formas culturais da espécie começam a fazer sentido para ele, e a linguagem ganha um aliado em seu desenvolvimento. Segundo Tomasello (1999), a atenção conjunta começa a ocorrer quando os bebês humanos têm 9 meses de idade e se desenvolve até os 15 
meses $^{19}$. A criança, muito antes dos 9 meses, já é capaz de reconhecer-se no outro, ou seja, sabe que seus cuidadores são seres como ela mesma, mas, segundo o autor, somente após a "revolução cognitiva" causada pela atenção conjunta é que os bebês começam a compreender o outro como um ser intencional, pois também começa a compreender-se como tal. Essa percepção possivelmente desencadeia processos cognitivos que levam a criança a primeiro ser capaz de estabelecer atenção de verificação, ou seja, ela consegue perceber que o adulto está prestando atenção em um objeto exterior a ambos; mais ou menos aos 11 meses, o bebê consegue prestar atenção ao objeto de atenção do adulto e seguir seu olhar em direção ao objeto (atenção de acompanhamento); posteriormente, a partir dos 13 meses, o bebê já é capaz de apontar, imperativa ou declarativamente para algo exterior a ele e ao adulto, a fim de obter algo (imperativo) ou apenas a fim de compartilhar atenção (declarativo).

Antes dos 9 meses, quando a criança apenas conseguia estabelecer interações diádicas, sua relação com o meio resumia-se a ações independentes, ora com um objeto, ora com o adulto. A partir dos 9 meses, quando a criança consegue estabelecer uma interação triádica, ou seja, quando passa a perceber que o adulto pode prestar atenção a algo exterior, essa capacidade cognitiva pode desencadear processos que levem às etapas posteriores, até chegar ao momento em que a criança percebe que, se ela apontar para algo externo a si e ao adulto, pode obter sua atenção. As interações triádicas, portanto, permitem à criança conhecer-se cada vez melhor, pois, assim, vivencia seus próprios objetivos e os efeitos de suas ações sobre o meio, e é isso que irá colaborar com o desenvolvimento de linguagem.

\footnotetext{
${ }^{19}$ Tomasello não diz que há um momento exato de surgimento da capacidade de atenção conjunta, entretanto, afirma que, curiosamente, é em torno dos 9 meses que isso acontece.
} 
Refletindo sobre a explicação de Tomasello e de seus colaboradores (1998 apud Tomasello, 1999) a respeito das fases de percepção da criança e da atenção dispensada a um objeto exterior, podemos entender que, ao mostrar que dos 9 aos 12 meses o comportamento de verificar é observado, mas que aos 11 meses já possível perceber o acompanhamento do olhar, aparentemente essas fases estão intrinsecamente ligadas, como se, ao passar a entender que o outro tem intenções com seus atos, a criança passasse também a amadurecer em si o fato de que o outro pode dar atenção a algo exterior a si e a ela, e então, a partir disso, desencadeasse o entendimento de que, se o outro pode prestar atenção a algo exterior, ela também pode prestar atenção à mesma coisa, e então, se isso é possível, se ela pode seguir a atenção do outro, o contrário também pode ocorrer. 0 resumo da atenção conjunta pode ser observado no quadro a seguir:

\begin{tabular}{|c|c|c|c|}
\hline Idade ${ }^{20}$ & Desenvolvimento & $\begin{array}{l}\text { Tipo de } \\
\text { Interação }\end{array}$ & Relação com o meio \\
\hline $\begin{array}{l}\text { Antes } \\
\text { dos } 9 \\
\text { meses }\end{array}$ & $\begin{array}{l}\text { O bebê é capaz de se } \\
\text { reconhecer no outro }\end{array}$ & $\begin{array}{l}\text { Interação } \\
\text { Diádica }\end{array}$ & $\begin{array}{l}\text { Relação com o meio resume-se a ações } \\
\text { independentes, ora com o objeto, ora } \\
\text { com um adulto. }\end{array}$ \\
\hline $\begin{array}{lr}\text { Dos } & 9 \\
\text { aos } & 12 \\
\text { meses }\end{array}$ & $\begin{array}{l}\text { O bebê consegue } \\
\text { prestar atenção ao } \\
\text { objeto de atenção do } \\
\text { adulto e direciona o } \\
\text { olhar para esse objeto } \\
\text { (atenção } \\
\text { acompanhamento). de }\end{array}$ & \multirow[t]{2}{*}{$\begin{array}{l}\text { Interação } \\
\text { Triádica }\end{array}$} & \multirow{2}{*}{$\begin{array}{c}\text { Permite à criança conhecer-se melhor, } \\
\text { pois, assim, vivencia seus próprios } \\
\text { objetivos e os efeitos de suas ações } \\
\text { sobre o meio. }\end{array}$} \\
\hline $\begin{array}{l}\text { A partir } \\
\text { dos } 13 \\
\text { meses }\end{array}$ & $\begin{array}{l}\text { O bebê é capaz de } \\
\text { apontar; imperativa ou } \\
\text { declarativamente para } \\
\text { algo exterior a ele e ao } \\
\text { adulto. }\end{array}$ & & \\
\hline
\end{tabular}

Quadro 3: Resumo da atenção conjunta

${ }^{20}$ As idades foram organizadas de forma didática para que se compreendesse a as fases de
maturação de uma capacidade cognitiva (a percepção) da criança, no entanto ressaltamos que
idades aproximadas, não sendo valores exatos determinados pela linha divisória da idade. 
Percebemos, então, que a maturação de uma pequena capacidade cognitiva, como a simples percepção do outro como um ser intencional pode desencadear outros processos cada vez mais complexos. Conforme Tomasello (1999), somente quando o bebê começar a perceber a intenção que existe por trás das coisas será possível que ele inicie também a aprender a respeito dos artefatos simbólicos e nãosimbólicos de sua cultura. Ao compreender a intenção do criador por trás de uma ferramenta como o martelo, por exemplo, seu significado simbólico passa a fazer sentido. O mesmo ocorre com a língua, um dos artefatos mais simbólicos que podemos encontrar. A língua exige de seus falantes uma compreensão das intenções abstratas por trás de seu uso para que faça sentido aprendê-la e usá-la para se comunicar. Muito cedo aprende-se que a língua é um dos maiores trunfos sociais da espécie humana, pois, por seu intermédio, o indivíduo é capaz de aproximar ou de distanciar pessoas, de caracterizar-se cultural, social e politicamente ou não socialmente, conforme o uso que dela fizer .

Pode-se, neste momento, inquirir sobre a capacidade de nossos parentes mais próximos, os chimpanzés, de reconhecer um espaço de atenção conjunta. Esta capacidade, se unicamente humana, poderia ser uma pista chave para encontrar o grande salto cognitivo que faz a espécie humana tão diferente das demais espécies primatas. De acordo com Tomasello (1999), apesar de serem capazes de reconhecer seus coespecíficos como seres intencionais, ou seja, seres que, ao agirem de tal maneira, têm intenções envolvidas por trás de tal ação, os chimpanzés não os reconhecem como seres intencionais como a si próprios, ou seja, não identificam que seus coespecíficos podem ter intenções como as suas e, 
principalmente, não compartilham intenções e informações deliberadamente, somente com o intuito de se comunicar.

Nas primeiras pesquisas desse autor envolvendo chimpanzés, Tomasello categoricamente afirmava que nenhum treinamento seria capaz de dar aos chimpanzés a predisposição biologicamente humana para se identificar com seus coespecíficos. Com os desenvolvimentos das pesquisas, entretanto, Tomasello e seus colaboradores (Tomasello, 2008; Tomasello \& Herrmann, 2010) assumiram uma posição mais cautelosa,principalmente porque puderam constatar que os chimpanzés entendiam que seus parceiros sociais agiam como seres intencionais e tinham objetivos e percepções (op. cit., 2010). O que aparentemente vem sendo apontado como a diferença-chave entre o aparato cognitivo da espécie humana e o desses animais é que os primeiros não evoluíram apenas nas capacidades cognitivo-sociais relacionadas à competitividade, mas, sobretudo, desenvolveram capacidades cognitivas direcionadas à cooperação, o que desencadearia motivações para compartilhar intencionalidade. E esse compartilhamento, por sua vez, fomentaria a aprendizagem e a transmissão cultural, além da interação comunicativa, que prevê a cooperação entre coespecíficos.

Uma metáfora para a transmissão cultural humana empregada por Tomasello (1999) permite compreender essa diferença postulada por eles. Trata-se do efeito catraca. Afirma o autor que, ao nos depararmos com um artefato útil de nossa cultura proveniente de outra época, tendemos a mantê-lo em uso, no máximo adaptando-o às nossas novas necessidades, mas esse artefato jamais perderia 0 significado simbólico já transmitido por ele. 
Como expusemos anteriormente, ainda que possam estabelecer alguma forma de atenção conjunta, os chimpanzés não compreendem a intencionalidade que é implícita em artefatos culturais que transcendem o tempo e o espaço. Portanto, ainda que possam de fato transmitir culturalmente, através de gerações, alguns comportamentos e informações ${ }^{21}$ (Whiten \& van Schaik, 2007 apud Tomasello e Herrmann, 2010), isso pode se perder muito mais facilmente do que o que é transmitido culturalmente entre os humanos, pois o efeito catraca não se manifestaria. Argumentam os psicólogos da evolução que a ausência do efeito catraca nos chimpanzés não impede que, em algum outro momento, um comportamento ou informação ressurja. Atribuem o fato a uma possível capacidade inata da espécie em facilitar esse surgimento.

Se a diferença-chave entre a cognição humana e a cognição dos outros grandes primatas não estiver na capacidade de estabelecer atenção conjunta, posto que seja possível para os chimpanzés realizar pelo menos duas das três fases da atenção conjunta estudadas por Tomasello (verificação e acompanhamento do olhar), talvez seja possível encontrar uma resposta na etapa seguinte a esse boom cognitivo que começa aos 9 meses da criança humana: a atribuição de estados mentais a seus coespecíficos, chamada teoria da mente.

Em um trabalho anterior, Tomasello (2008) apresenta semelhanças e diferenças entre a comunicação humana e a comunicação dos grandes primatas não-humanos. Vejamos o quadro a seguir:

\footnotetext{
${ }^{21}$ Sobre esse aspecto, como já expus, há controvérsias.
} 


\begin{tabular}{|l|l|}
\hline Comunicação humana & Comunicação não-humana \\
\hline Ação intencionalmente & $\begin{array}{l}\text { Ação baseada na intencionalidade } \\
\text { individual }\end{array}$ \\
\hline $\begin{array}{l}\text { Compreesão das intenções dos outros } \\
\text { seres de sua espécie }\end{array}$ & $\begin{array}{l}\text { Entendimento das intenções de outros } \\
\text { seres de sua espécie }\end{array}$ \\
\hline Compartilhamento intenções & Não compartilhamento intenções \\
\hline COLABORAÇÃO mútua & NÃO colaboração mútua \\
\hline $\begin{array}{l}\text { Cooperação a fim de alcançar um } \\
\text { objetivo }\end{array}$ & Comportamento egoísta e individualista \\
\hline
\end{tabular}

Quadro 4: Características da comunicação humana e não-humana segundo Tomasello.

Três são as razões apresentados por Tomasello (idem) as quais deflagram a comunicação humana cooperativa: (i) a concessão de pedidos ou informações, (ii) o oferecimento de ajuda e (iii) o compartilhamento de emoções. O primeiro motivo, a concessão de pedidos ou informações, baseia-se no processo de cooperação chamado mutualismo e está relacionado à inferência de que, concedendo pedidos ou informações, o ser humano está visando a um mútuo benefício. A colaboração mutualista parece ser a origem do conhecimento comum de mundo, necessário para uma comunicação cooperativa rica e efetiva.

O segundo motivo, o oferecimento de ajuda, baseia-se no processo de reciprocidade direta, que está relacionada ao desejo de melhorar a reputação perante $\circ$ grupo. Uma diferença entre as duas espécies primatas aqui tratadas emerge do fato de que os seres humanos auxiliam e solicitam auxílio também fora de contextos mutualistas. Nesses casos, a "reciprocidade indireta", ou seja, o oferecimento de auxílio também em situações em que não há a recepção de benefícios, contribui para melhorar a própria reputação e faz com que, no futuro, 
outras pessoas possam colaborar em resposta. As atividades colaborativas humanas são, assim, a origem da comunicação cooperativa.

E o terceiro motivo, compartilhamento de emoções, baseia-se na seleção de grupo cultural, e está relacionado à necessidade de se reafirmar membro de um determinado grupo. O processo básico de seleção do grupo permite tratar da importância que a função de imitação assumiu na história da evolução humana. Essa função se inicia com o aprendizado por imitação aos semelhantes e se desenvolve até a aquisição de uma função social. Isso ocorre, porque a imitação é uma maneira de expressar solidariedade com os indivíduos pertencentes ao grupo. Isso nos leva a questionar se o texto, uma forma de expressão cultural humana, tendo uma função social, também seria aprendido por imitação? Ou seria uma transferência de conhecimento para uma nova forma de expressão, tal como prevê o efeito catraca? Essas são algumas das questões que discutiremos no capítulo IV.

A comunicação humana cooperativa, então, teria como principal característica a habilidade de compartilhar intencionalidade e também a motivação para o pedido e para a oferta de ajuda e compartilhamento de informações. A habilidade cognitiva básica do compartilhamento de intencionalidade é, segundo Tomasello, a recursividade, que, combinada com a disposição para fornecer ajuda, leva a expectativas mútuas de ajuda entre os seres humanos. Essa característica colaborativa unicamente humana tem sua origem no comportamento generoso da espécie. 
Como o tema trata da recursividade da mente ${ }^{22}$ manifestada na linguagem, torna-se fundamental abordar um assunto recorrente em cognição e comunicação: a intersubjetividade. A noção de intersubjetividade é discutida por Maturana (2001) com um enfoque biológico, interessante viés para a comparação com os estudos linguísticos.

O autor traz para a discussão a teoria da autopoiese, que se baseia na semipermeabilidade dos sistemas dos organismos vivos. Isso faz com que, em suas interações com o meio ${ }^{23}$, mudanças ocorram tanto nos organismos quanto nesse meio, de modo que a coerência interna de ambos seja mantida. Nessas interações, os organismos se permitem mudar pelas pressões do meio, e também agem sobre esse meio provocando mudanças, num mecanismo de constante adaptação de ambas as partes com vistas à própria sobrevivência. Não coincidentemente, o mesmo processo pode se manifestar na língua.

A teoria da autopoiese aproxima-se do sentido de intersubjetividade justamente com a manifestação desse mecanismo, pois seres e meio se recognizam durante as interações e assim se mantêm vivos e evoluem. Quando essa coerência não pode ser mantida, ocorre a destruição. Maturana considera, então, a linguagem como um sistema autopoiético, pois, promovendo a interação, também sofre e causa mudanças, mantendo-se em constante equilíbrio entre a ordem e o caos.

\footnotetext{
${ }^{22} \mathrm{O}$ termo leitura recursiva se aplica nesta tese em virtude de se tratar de uma faculdade inata da linguagem, que se encontra apenas na mente humana.

${ }^{23}$ Por meio compreendam-se o ambiente e outros seres vivos.
} 
O filósofo Schutz (1967) dialoga com Maturana. Em seu trabalho, Schutz dá maior enfoque aos sujeitos em interação. $O$ autor abandona a atitude fenomenológica, ou seja, a observação da real situação de interação, por exemplo, despida de qualquer ponto de vista, crença ou percepção do observador, e trata do entendimento da intersubjetividade sob o ponto de vista da atitude natural, ou seja, sob o ponto de vista do observador do que é a realidade. Na atitude natural, nós, seres humanos, compreendemos o mundo e nossos semelhantes porque sabemos que o outro é igual a nós, com sentimentos,qualidades, defeitos, percepções etc., embora cada um tenha sua própria experiência de mundo e seu próprio ponto de vista sobre as coisas.

Para lidar com a compreensão do outro, Schutz (1967) defende a ideia do pareamento limitação-inacessibilidade, segundo a qual o entendimento que temos do outro é limitado e sua experiência subjetiva é inacessível, na medida em que nosso conhecimento de nós mesmos é ilimitado e temos total acesso a nossa experiência subjetiva. Para que percebêssemos a experiência subjetiva do outro exatamente como ele a vivenciou, teríamos que ser o outro. Cada um de nós experimenta a própria experiência de maneira única, e o que podemos dizer que estamos testemunhando quando participamos da experiência do outro é nossa própria experiência da experiência do outro, enviesada por nosso ponto de vista.

Ao experimentar a experiência alheia, temos a oportunidade de, inclusive, vivenciar fatos da experiência do outro de que nem mesmo ele teve consciência. De acordo com o autor, também é possível apreender as experiências do outro a partir de seu corpo ou de objetos produzidos por ele, como artefatos, músicas, obras de arte etc. Entretanto, a experiência projetada será sempre a nossa experiência da 
experiência alheia, e jamais sua experiência subjetiva. O autor discorre também sobre a corrente de consciência do outro sendo simultânea à do eu. Podemos ter uma experiência simultânea da experiência do outro enquanto ele a vive, mas não podemos observar nossa própria experiência simultaneamente, senão por um ato reflexivo. Ou seja, a observação da nossa própria experiência somente pode ser feita no passado, enquanto a observação da experiência do outro pode ser simultânea. Essa simultaneidade tem a ver com a duração (durée) de cada um, que, além de ser experienciada subjetivamente pelo eu, também é experienciada pelo outro como uma realidade (cada envolvido na interação experiencia a durée do outro). O conceito de simultaneidade aqui, por não ser temporal, permite que a corrente de consciência de pessoas de tempos diferentes possa ser colocada imaginariamente em simultaneidade, e é por isso que podemos ter uma experiência da experiência de outras pessoas por meio de seus artefatos, obras de arte, músicas etc., ainda que sejam de outra época.

Schutz (1967) explica que a simultaneidade na corrente de consciência não quer dizer que as pessoas tenham o mesmo ponto de vista do mundo, pois cada um vive suas experiências e entende o mundo de maneira diferente. A simultaneidade, inclusive, não pressupõe a mesma experiência para todos os participantes da interação, cada um tem a própria experiência da experiência do outro.

Quando interpretamos nossas próprias experiências e as experiências alheias, fazemos isso a partir de nossas experiências prévias e de experiências previamente vividas das experiências do outro, se estas ocorreram. O autor recorre ao conceito de contextos de significação, que se refere ao fato de buscarmos experiências anteriores para interpretar novas experiências vividas dentro de um 
mesmo contexto. Ou seja, podemos também buscar experiências que já tivemos da experiência do outro para interpretar novas experiências vividas de sua experiência, mas obviamente o acesso a essas experiências é limitado, pois as experiências do outro não são abertas a nós, apenas acessamos as partes de sua experiência que experienciamos. Portanto, sempre haverá dúvidas a respeito das experiências vividas pelo outro, mas nosso conhecimento sobre nós mesmos pode soar indubitável, pois se trata de nossas próprias experiências, contínuas e em sua totalidade. Percebemos em alguns textos os alunos procurarem argumentar sobre suas experiências ou experiências dos outros, daí iniciarem os textos fazendo alusões a fatos históricos ou a suas experiências, todas elas com o fito de criar um cenário para contextualizar o próprio texto.

Dado que a língua é essencialmente instrumento de comunicação, possui uma estrutura flexível e evolui sujeita a pressões originadas dos diferentes contextos comunicativos. Lidar, assim, com a instância do uso é de fato o locus mais seguro para compreendê-la em sua integralidade.

A perspectiva funcionalista sob o ponto de vista da linguística cognitiva permite lidar com a significação decorrente do uso de palavras e frases contextualizadas, o que implica o reconhecimento de que os conceitos manifestamse associados a padrões criados culturalmente (MARTELOTTA \& AREAS, 2003). Isso permite afirmar que a linguística cognitiva adota uma perspectiva baseada no uso, tendo como uma de suas principais hipóteses a ideia de que o contexto orienta a construção do significado (FERRARI, 2011) caracterizando o conhecimento enciclopédico como um sistema estruturado e organizado em rede. 
A título de ilustração, analisemos uma frase apresentada por Bechara (1999) durante sua exposição sobre predicado verbo-nominal, a que ele prefere rotular, justificadamente, de predicativo anexo: "Encontrei a porta arrombada". Duas leituras podem ser depreendidas dessa frase excluída de seu contexto de realização, como demonstram Silva et alii (no prelo): (a) que existe a certeza de que uma porta arrombada existe no local e que um indivíduo a localizou; (b) que um indivíduo localizou a porta que procurava, no entanto, contrariando suas expectativas, ela estaria arrombada. Somente o contexto de emprego da frase permitirá reconhecer o que de fato o falante pretendeu codificar com essa frase. Numa situação qualquer de comunicação face a face, talvez a entonação pudesse resolver essa ambiguidade, mas isso não sucede com a frase solta na gramática que explana essa frase.

Reconhecer a ambiguidade não é normalmente o papel do funcionalista, a menos que a manutenção da ambiguidade seja intencional na fala do indivíduo. É tarefa do analista funcionalista compreendê-la no contexto de realização, e dele depreender o sentido codificado pelo falante.

Portanto, lidar com a rede enciclopédica pode ser uma saída interessante, se ela realmente der conta do contexto de realização das sentenças. Observemos a classificação proposta por Langacker (1987), em quatro tipos de redes: (i) convencional - é a informação conhecida e compartilhada pelos membros de uma comunidade de fala; (ii) - genérica - é o grau de que uma informação é genérica, ao invés de específica; (iii) - intrínseca - é a caracterização do significado que não leva em conta fatores externos; (iv) - característica - é a informação suficiente para identificar o membro de uma classe, dado seu caráter único. 
Aplicando-as à análise da frase anterior, nota-se que favorece a análise do conteúdo do segmento estudado, mas cada um isoladamente não permite reconhecer, fora do contexto, a significação intencionada pelo falante. Numa tentativa de estender essa tipologia ao objeto de interesse nesta tese, as estruturas introdutórias das redações escolares dissertativas parecem oferecer alguma compreensão adicional já que, diferentemente da frase apresentada por Bechara, as redações nascem na modalidade escrita, já distanciada da interação face a face. Então, essa tipologia parece favorecer acesso aos diferentes aspectos do conhecimento, ou ainda aos diferentes cenários construídos pelo indivíduo para que contextualize o interlocutor, objetivando tornar clara e precisa a informação escrita.

\subsubsection{Princípios funcionalistas}

A imprensa publica o que devemos ou não fazer em uma redação e etc. Mas será que escrever uma redação se trata de uma "fórmula mágica"? Uma fórmula que se fosse cumprida daria certo e pronto? Acreditamos que não, uma vez que fosse assim, todos seguiriam o padrão e a nota alta seria garantida. Sabemos que nem sempre os melhores alunos do ensino médio, ou os alunos que se prepararam muito nos melhores cursinhos necessariamente tiveram êxito na produção textual.

Outros aspectos, além das técnicas de escrita, contribuem na hora de escrever: fatores como o controle emocional em um momento de tensão, conhecimentos extra-linguísticos como cultura, economia, política, todos influenciam para a escrita de um texto. Direcionados pelos pressupostos do funcionalismo, 
analisaremos os textos sobre os princípios e as categorias centrais dessa corrente: informatividade, iconicidade, marcação e, por fim, fundo e figura.

A informatividade é um princípio parte da ideia de que o conhecimento é compartilhado, ou supõem que compartilham, pelos interlocutores durante a interação verbal. O estudo desse princípio permite reconhecer uma diferença baseada em quatro tipos baseados na acessibilidade da informação: dado, novo, disponível e inferível.

Já a iconicidade pode ser definida como a correlação entre código linguístico (expressão/forma) e seu significado (conteúdo/função), estabelecendo portanto uma relação de um para um. Esse princípio se manifesta na quantidade de informação que um texto apresenta. A estrutura de uma construção gramatical indica a estrutura do conceito que ela expressa, isto é, quanto mais complexo o pensamento, materializar-se-á de forma mais complexa. Em contrapartida, pensamentos que se manifestam de forma mais simples, se expressam com mecanismos morfológico e gramatical menos complexos.

O princípio da marcação é importante no que diz respeito ao uso da língua, pois uma forma mais corriqueira, que apresenta alta frequência de uso, tende a ser conceptualizada de modo mais automatizado pelo usuário da língua e isso significa que essa forma tem pouca expressividade. Desta forma, quando queremos ser expressivos usamos as formas marcadas.

Os termos "marcados" e "não-marcados" remetem ao contraste de dois elementos de uma categoria linguística. Para o nosso campo de trabalho, escolhemos a categoria sintática para estabelecermos os elementos de oposição. 
De acordo com Cunha et al. (2003, p. 34), para classificarmos as formas "nãomarcadas", é necessário considerar as seguintes características:

a) Complexidade Estrutural: a estrutura marcada tende a ser mais complexa (ou maior) que a estrutura não-marcada correspondente;

b) Distribuição da frequência: a estrutura marcada tende a ser menos frequente do que a estrutura não-marcada correspondente;

c) Complexidade cognitiva: a estrutura marcada tende a ser cognitivamente mais complexa do que a estrutura "não-marcada" correspondente. Incluem-se, aqui, fatores como esforço mental, demanda de atenção e tempo de processamento.

Tendo em vista que as informações são codificadas de modo a distribuir a sintaxe de modo a chamar a atenção do interlocutor ou leitor para alguns pontos do texto, por razões diversas, então é importante retomar a ideia de planos discursivos. São eles as estratégias que adotamos, via sintaxe, para focalizar ou desfocalizar informações, guiando a atenção do outor e fazendo-o perceber nossas intenções discursivas no processo interativo. Dois são os planos discursivos estudados por funcionalistas: fundo e figura.

O plano da figura (foregrounding) apresenta-se como o de primeiro plano, o que pede a atenção, pois ativa o estado de vigília para o que é dito ou escrito. Constitui-se invariavelmente mais simples morfossintaticamente, por isso mesmo apresentando-se na forma de verbos pontuais, no aspecto perfectivo, com polaridade positiva e referindo-se à situações objetivas. Mas, como tudo na língua é 
resposta em termos de gradação de complexidade, pode ocorrer de essas características associarem-se a outras mais complexas para também produzir uma informação mais complexa.

Já, o plano de fundo (backgrounding), que é o plano periférico, invariavelmente apresenta-se como uma codificação morfossintática mais complexa, com eventos não necessariamente completos, situações descritivas e simultâneas, em que uma variedade de tópicos se consubstancia. No entanto, devido à gradação de complexidade, pode-se identificar distribuição regular de sujeitos focalizados, de sentenças adverbiais deslocadas esquerda e maior presença de verbos em seus aspectos imperfectivos.

O plano de fundo é mais complexo que o de figura, pois demanda atenção dupla dos interlocutores. Ao mesmo tempo em que deve ouvir e captar a informação, também haverá a demanda das informações de fundo. Num simples exercício de elaborar uma redação, por exemplo, deve-se depreender um tema para explanação e também as informações contextuais (para quem e com que objetivo está redigindo, o que esperam do escrevente como linguagem) e cotextuais (que outras informações na proposta podem ajudar a alcançar o objetivo).

Considerando as redações que integram o corpus sob análise, notamos que, quando a sentença não obedece à estrutura SVC, bem como quando não há a presença de expressões temporais e locativas no início do parágrafo, percebemos que há uma tentativa mais significativa e complexa para contextualizar o leitor (crianção de um plano de fundo). Para isso são requeridas formas mais abstratas, trazendo uma ideia de localização, porém não de tempo cronológico, nem de lugar 
físico, mas de estrutura que situa o leitor em determinado contexto. Assim, o que é aparentemente tempo, na verdade, produz outros sentidos no texto.

\subsubsection{A Gramaticalização em processo}

A gramaticalização pode ser analisada, segundo Gonçalves, Lima-Hernandes e Galvão (2007), como paradigma (uma visão mais global da mudança tendo em vista o modo como afeta a construção-fonte e a construção-meta) ou pode ser tomada como um processo (uma perspectiva mais voltada para fases dos deslizamentos operados, de modo a descortinar a gradação implicada).

Neste trabalho, assumimos a perspectiva da gramaticalização como um processo e visamos à identificação do processo de deslizamento funcional das construções temporais mais recorrentes no parágrafo introdutório das redações da Fundação Universitária para o Vestibular - FUVEST. Os deslizamentos funcionais entre as categorias cognitivas serão alvo de discussão nesta tese, portanto.

Gramaticalização, enquanto processo, tem sido definida por muitos linguistas. Todos, em algum momento de sua conceituação, resgatam a definição primária de Meillet, (1912), conforme sinalizam Campbell \& Janda(2001:95):

The 'grammaticalization' of certain words creates new forms, introduces categories that did not use receive linguistic expression, [and] transforms the overall system formed. 
Recorrem a ele porque Meillet foi o pai do termo na linguística e porque sua ideia de mudança em processo, demonstrada pela evolução do verbo ir em francês revela a propriedade relativa à analogia (processo pelo qual um novo modelo tornase semelhante a um modelo já estabelecido) e à reanálise (atribuição de caráter gramatical a uma palavra independente). Foi um admirador de seu trabalho, Karl Vossler (1944[1923]), quem defendeu não haver mudança de natureza gramatical que vingasse sem que uma alta repetição do uso se procedesse no bojo da sociedade.

Aproximadamente 50 anos depois de Meillet, Kurylowicz (1965/1975), conforme relatam Heine, Claudi \& Hünnemeyer (1991) e os que derivam suas discussões desse livro fundamental sobre gramaticalização, dentre os quais citamos Campbell \& Janda (2001), Lima-Hernandes (2005) e Gonçalves, Lima-Hernandes \& Galvão (2007), retoma o rótulo gramaticalização para se referir ao surgimento de um morfema que avança de um status lexical para gramatical. Somente anos depois é que se tem a percepção de que itens já gramaticais poderiam ser tornar mais gramaticais ainda. Num grande salto no tempo, mais precisamente em 1982, Christian Lehmann forneceu uma definição mais explícita em um trabalho que foi amplamente divulgado em 1982, revisto ligeiramente em 1985, mas não publicado oficialmente até 1995 (CAMPBELL \& JANDA, 2001, p.95). Nesse trabalho, Lehmann oferece critérios mais seguros para se medir a gramaticalização, mas esses critérios davam conta mais precisamente dos itens que cumpriram todo o processo de mudança de lexical a gramatical, alcançando mesmo um estatuto zero.

Ainda que Lehmann considere a gradualidade como sendo característica da mudança, afirmando que processos semânticos, sintáticos e fonológicos interagem 
na gramaticalização de um morfema e de construções, seus critérios não permitem apreender essas mudanças em processos incipientes. Foi essa a crítica de Hopper ao postular outros princípios de gramaticalização, porém voltados para a fase inicial do processo. Muitos testaram esses princípios com sucesso, mas a ciência caminhou.

De lá para cá, muitos foram os trabalhos e as descobertas realizadas. Todas, mesmo as tentativas de defender uma reversão do continuum de mudança, ratificaram que o processo, uma vez instaurado, percorre uma evolução em seu caráter concreto em direção a um estatuto mais abstrato. É certo que, a depender do tipo de categoria elencada para essa observação, o resultado pode ser confuso. Explica-se esse fato pela arbitrariedade das categorias postuladas ou, como defenderam Heine, Claudi \& Hünnemeyer (1991), pelo enviezamento da análise (vide Gonçalves et alii, 2007, para mais detalhes).

A gramaticalização tem sido estudada maciçamente por diversos linguistas, principalmente após os anos 90. De acordo com Heine, Claudi \& Hünnemeyer (1991, pp. 19-30), o processo de gramaticalização pode ser observável em todas as línguas e pode envolver qualquer tipo de função gramatical. Mais adiante, será possível observar que esse mesmo processo pode detonar um processo que culmine com o surgimento de uma construção ou unidade maior. Mas mesmo o conceito de construção já embute em si a evolução de unidade surgida diacronicamente

Segundo esses autores, a gramaticalização ocorreria devido às necessidades de comunicação não-satisfeitas pelas formas existentes no sistema linguístico e à existência de conteúdos cognitivos para os quais não existem designações 
linguísticas adequadas. Sabemos, hoje, que nem sempre são essas as motivações, especialmente quando descobrimos, tal como Lima-Hernandes (2008, 2010), Zambrano (2012), Defendi (2008, 2012), Silva (2012), Rauber (2012), Rauber \& Ribeiro (2012), Sartin (2008, 2012), Ribeiro (2012), Vicente (2009), Bernardo (2009), Barroso (2008), dentre outros trabalhos desenvolvidos nessa perspectiva, e mais recentemente Defendi (2013), que a situação interativa, o fato de pressupormos que o outro já saiba algo sobre o que falamos podem fazer surgir nova codificação sintática, via elisão de sintagmas intermediários produtivos nesse tipo de cadeia sintática.

Antecedeu essa concepção de construção, mas continua contribuindo com seus princípios, Hopper (1991), que traz para discussão a ideia de que a gramática da língua é sempre emergente e nunca presente. Com esse autor, vê-se mais explicitamente aproveitada a ideia de dinamicidade da língua, posto que, a partir de então, foi possível apreender processos de mudança em estágios bem iniciais.

Em outro estudo influente, Hopper \& Traugott (1993) definem gramaticalização como processo pelo qual itens e construções lexicais, em certos contextos linguísticos, desempenham determinadas funções gramaticais e, uma vez gramaticalizados, continuam a desenvolver novas funções. Segundo esses autores, gramaticalização pode ser estudada sob aspecto histórico, ou seja, nessa perspectiva envolvem-se as fontes de formas gramaticais e os percursos típicos das mudanças que os afetam. A outra perspectiva é sincrônica, que lida com a gramaticalização fundamentalmente num recorte temporal, a qual escolhemos para o desenvolvimento desse trabalho. 
Mais recentemente, o Grupo de Pesquisa CNPq-USP "Mudança Gramatical do Português - Gramaticalização", rebatizado devido a um avanço maior e especialização mais estrita dos fenômenos estudados como Grupo de Pesquisa Linguagem e Cognição, ao qual se filia diretamente esta tese, tem promovido uma aproximação entre aspectos psicológicos e aspectos linguísticos. Se parece uma visão inovadora, de fato não o é. Trata-se, na verdade, de um recuo nas propostas apenas sugeridas por Vossler (1944[1923]), Jespersen (1947) e Wartburg (1946), os quais descreveram fatos linguísticos em línguas diferentes, mas sintonizados na ideia de que os aspectos individuais e culturais poderiam ser manifestados nos processos de mudança operados. As ideias desses autores foram colocadas em diálogo com estudiosos que assumem um viés mais psicológico atualmente, tais como Tomasello (2003 [2000]) e Givón (1979).

Dessas incursões, nasce uma preocupação com aspectos diversos dos linguísticos que são incorporados como marcas na língua em uso. Lidar com princípios, mecanismos e contínuos de evolução gramatical permitirá alcançar as razões por que selecionamos, a despeito de temas diversos, de escreventes diversos, de épocas diversas, as mesmas estratégias para iniciar os textos dissertativos escolares no contexto de exame vestibular.

\subsubsection{O princípio da unidirecionalidade}

Alguns autores utilizam o rótulo continuum para tratar dos deslizamentos funcionais entre classes de palavras como, por exemplo, o desenvolvimento de advérbios ou preposições em conectivos oracionais (TRAUGOTT, 1988). Segundo Lima-Hernandes (2005), para explicar um deslizamento representado em linha, é 
necessário incluir mais de uma categoria, como ocorre na trajetória parcial da palavra tipo. Para a pesquisadora, os exemplos postulados como mais antigos associam a palavra tipo a categoria nome e, ao mesmo tempo, aos traços semânticos [+ humanos, + animado, + concreto]; já os exemplos de usos mais recentes associam tipo ao padrão funcional discursivo - marcador.

Heine et alii (1991a) apresentam uma ordenação de categorias cognitivas, pelas quais se observa um processo de abstratização: pessoa > objeto > processo $>$ espaço $>$ tempo $>$ qualidade. Essa unidirecionalidade demonstra que as mudanças, via gramaticalização,são operadas sempre da esquerda para a direita e, nesse caso, de categorias cognitivas mais próximas do indivíduo, [ +concretas], para categorias mais distantes do indivíduo [-concretas]. A escala proposta por Heine, Claudi e Hünnemeyer (1991), deve ser vista como um grupo de domínios e como um reflexo de mesmas tendências. Nesse sentido, os autores se esforçaram para sistematizar um conjunto básico desses domínios, que são agrupados, respeitando alguns princípios básicos, como: a habilidade de estruturar o sentido em padrões de conhecimentos e crenças, a noção do pensamento corporificado e a exploração de velhos meios para novas funções. 


\section{CAPÍTULO II}

\section{Tempo e Espaço: Construindo o primeiro parágrafo}

O tempo e o espaço são modos pelos quais pensamos e não condições nas quais vivemos. (Albert Einstein)

Nesta seção exploraremos os conceitos de tempo e espaço por se tratarem de duas categorias cognitivas muito presentes nos parágrafos introdutórios dos candidatos ao vestibular.

\subsection{A metaforização do tempo}

O que é o tempo?

"Uma ilusão. A distinção entre passado, presente e futuro não passa de uma firme e persistente ilusão." (Albert Einstein)

O tempo, além de estar presente na natureza física e biológica do próprio ser humano, ele apresenta muitas conotações. Tais conotações podem variar de acordo com a ciência, a cultura, a religião e o contexto social. O tempo, apesar de vinculado a eventos externos ao indivíduo, sempre será definido de forma idiossincrática, talvez por isso Einstein o tenha definido de ilusão. Na verdade, trata- 
se de uma grandeza física presente não apenas no cotidiano como também em todas as áreas e cadeiras científicas.

A noção humana de tempo encontra-se ligada ao sentido da visão, o que faz com que a noção humana de tempo encontre-se influenciada pela luz e suas propriedades, exemplo disso são os $300.000 \mathrm{~km} / \mathrm{s}$ - designado velocidade da luz. Vale ressaltar que a criança de colo não têm a noção de tempo, e adultos com certas doenças neurológicas ou psiquiátricas podem perdê-la.

Pesquisadores matemáticos, físicos, filósofos e curiosos ao longo da história da humanidade buscam entender o que é o tempo, contudo, ainda não há um consenso da definição. Para o ser humano, de modo geral, é um evento psicológico, ou ainda intervalos ou períodos de duração em que um acontecimento ocorre depois de outro acontecimento.

Na mecânica clássica tem-se por definição que a coincidência de eventos em um dado referencial implica a coincidência destes dois eventos em quaisquer outros referenciais, sendo o tempo neste contexto definido como uma grandeza absoluta e explicitamente independente do referencial.

Para física e outras ciências, o tempo é considerado uma das poucas quantidades essenciais. O tempo é usado para definir outras quantidades - como a velocidade - e definir o tempo nos termos dessas quantidades iria resultar numa definição redundante. Por influência da teoria da relatividade idealizada pelo Físico Albert Einstein, o tempo vem sendo considerado como uma quarta dimensão do continuum espaço-tempo do Universo, que possui três dimensões espaciais e uma 
temporal. A teoria da relatividade restrita, conforme publicada por Albert Einstein em 1905, substitui os conceitos independentes de espaço e tempo da Teoria de Newton pela ideia de espaço-tempo como uma entidade geométrica unificada.

A mecânica quântica suscite o debate de causa e efeito, indissociável do conceito de tempo. Se em um referencial o evento 1 é causa do evento 2, precedendo-o no tempo, portanto, em qualquer outro referencial esta relação de causalidade será preservada, mesmo que a medida do intervalo de tempo entre os eventos possa ser diferente.

$\mathrm{Na}$ localização geográfica, quando uma televisão ou um cineasta pretende indicar, por exemplo a Grã-Bretanha, uma maneira popular de fazer isso é mostrando uma imagem da Torre do Relógio Big Ben. O relógio tornou-se um símbolo do Reino Unido e Londres.

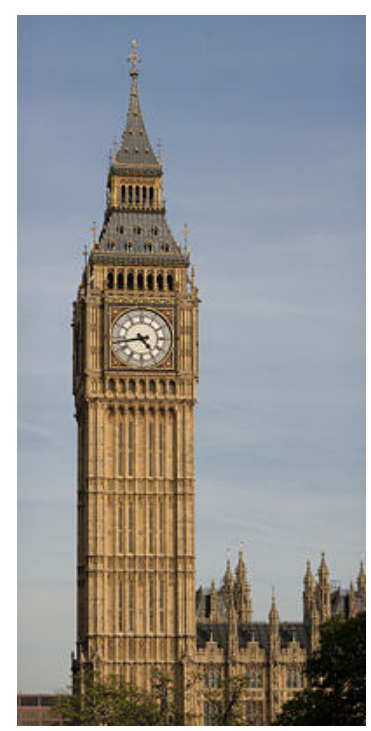

Figura 1: Torre do Relógio do Big Ben

As badaladas do sino, os fogos de artifícios lançados ao lado da torre, milhares de pessoas gritando "Happy New Year" e estourando champanhes ao redor 
do Big Ben fazem da Torre do Relógio um grande ponto de encontro para as celebrações de Ano Novo no Reino. Da mesma forma, no Dia da Lembrança (Remembrance Day) no Reino Unido, as badaladas do Big Ben são transmitidas às 11 horas do dia 11 do mês 11 e início de dois minutos de silêncio em homenagem a vítimas de guerras.

Medir o tempo significa registrar coincidências, logo é preciso um aparelho que produza eventos repetitivos e regulares - o relógio. Quando alguém marca um compromisso às 13 horas, está informando que estará no local combinado quando o ponteiro grande do relógio coincidir com a marca "12", e o ponteiro pequeno coincidir com a marca "1".

Na ausência de relógios artificiais, a humanidade valeu-se, ao longo de sua história, da regularidade observada em certos fenômenos naturais, para estabelecer seus padrões de medida do tempo: nestes termos à rotação da Terra devemos o intervalo de tempo conhecido por 1 dia, às fases da Lua devemos a definição de semana - período equivalente a 7 (sete) dias; a Lunação serviu de base para a definição de mês, à Translação da Terra devemos o conceito de ano. As unidades de tempo mais usuais são o dia, dividido em horas, e estas em minutos, e estes em segundos. Os múltiplos do dia são a semana, o mês, e o ano, e este último pode agrupar-se em décadas, séculos e milênios.

A natureza é caracterizada por fenômenos cíclicos em que a hora certa para muitos é tudo. A exemplo, um urso sabe o momento certo de hibernar, uma árvore o instante de abrir seus botões, um sapo, a hora certa de lançar sua língua para capturar seu jantar. Nesses seres vivos não há um "órgão do tempo", no entanto, no 
homem, cientistas já identificaram mecanismos biológicos como o relógio de intervalo e o relógio circadiano que os permitam cronometrar e registrar o tempo.

O cérebro humano desenvolveu mecânismos que atuam como um cronômetro; a exemplo disso, temos a situação em que um motorista para no sinal de trânsito e, depois de algum tempo, parte com carro em segundos próximos do farol tornar-se verde. Também é possível confirmar o desenvolvimento desse cronômetro, quando o ser humano habitualmente acorda sempre no mesmo horário, muitas vezes ele nem precisa do toque do relógio. Nestas situações, bem como em outras, o controle do tempo só é possível em virtude de processos ocorridos no cérebro humano que ativam e desativam o relógio de intervalo, que é relativamente preciso ao menos em situações normais. Esse processo de ativação e desativação ocorre no homem há milhares de anos, como em exemplos do seu próprio cotidiano, quando ele sabe em qual horário ou época é melhor para realizar a pesca e etc.

Os processos psicossomáticos que levam ao relógio de intervalo começam, segundo os estudos de Stephen Rao, Warem Meck e Gibbon (2002), em uma região do cérebro denominada gânglios basais, conhecida por corpo estriado, percorre um circuito, do córtex para o corpo estriado, deste para o tálamo e depois voltando ao córtex."

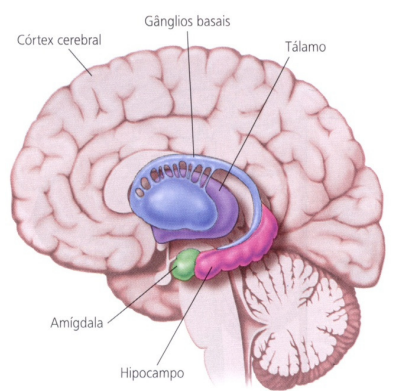

Figura 2: Cérebro humano ${ }^{24}$

\footnotetext{
${ }^{24}$ Esta figura está ampliada no anexo II desta tese.
} 
O relógio de intervalo tem entretanto uma característica muito peculiar se comparado a um cronômetro convencional seu funcionamento é influenciado pelo estado emocional, isso justifica a sensação de segundos durarem minutos ou horas quando estamos submetidos a situações desagradáveis ou de estresse.

O relógio circadiano encontrado disperso em cada órgão ou sistema conforme Joseph Takahashi (2002), é responsável por sincronizar os processos fisiológicos que ocorrem com os períodos diurnos e noturnos que se sucedem a cada 24 horas. Controla desde a nossa vontade de dormir ou acordar até o funcionamento completo de órgãos digestivos, urinários, cujos funcionamentos são normalmente suprimidos durante a noite.

O cinema traz à tona viagens que percorrem o passado, atravessa 0 presente e projeta o futuro, tais como nos títulos ${ }^{25}$ : $A$ Máquina do Tempo (The Time Machine, 1960), Planeta dos Macacos (Planet of Apes, 1968), 12 Macacos (Twelve Monkeys, 1985), Trilogia De Volta Para o Futuro (Back To The Future Trilogy, 1985, 1989 e 1990), Feitiço do Tempo (Groundhog Day, 1993), Efeito Borboleta (Butterfly Effect, 2004), Crimes do Tempo (Los Cronocrímenes, 2007), Perguntas Frequentes sobre Viagem no Tempo ( F.A.Q. About Time Travel, 2009), Série Exterminador do Futuro (Terminator, 1984, 1991, 2003 e 2009) e O Homem do Futuro (Brasil, 2010). Há também o filme Tempos Modernos, que se destaca por relacionar fatos históricos sob uma perspectiva futurista. É diante deste panorama, que a ideia de tempo que tanto permeia a vida da humanidade, é explorada.

\footnotetext{
${ }^{25}$ No anexo I desta tese, há um resumo para consulta dos filmes que estão relacionados.
} 


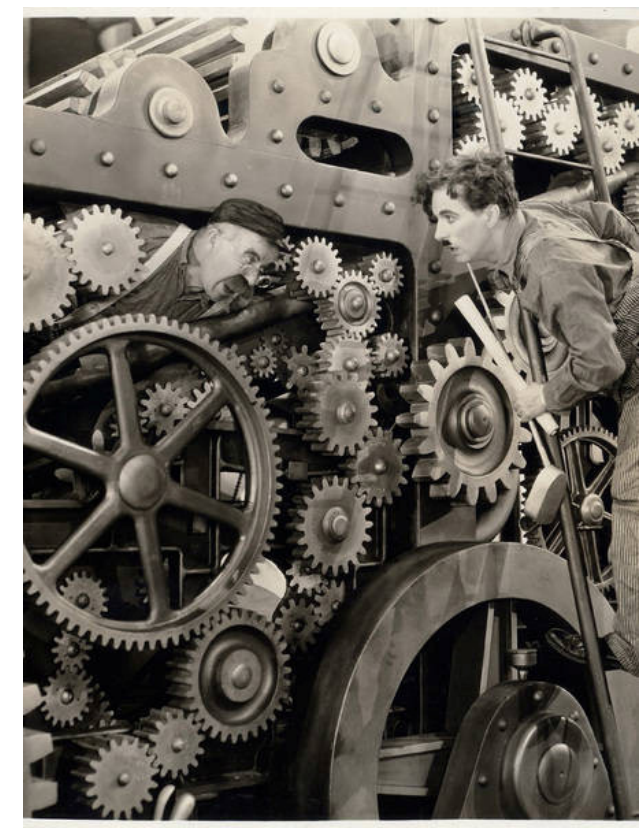

Figura 3: Cartaz do filme Tempos Modernos

Tempos modernos retrata o futuro, é uma obra cinematográfica que, na época de seu lançamento, causou muita polêmica por causa das críticas à Revolução Industrial, às citações sobre o comunismo e à social-democracia, enfrentando censura em muitos países, como a Alemanha Nazista. Em contrapartida, foi bem recebido pelos críticos e considerado uma das maiores produções do cinema mudo.

No Brasil, podemos citar como exemplo de obra cinematográfica relacionada ao tempo o filme Narradores de Javé. Nele é narrada a história de um povo que quer que sua cidade seja tombada como patrimônio histórico, para que não seja alvo do progresso. Então, os líderes da comunidade resolvem fazer um documento científico contando suas próprias histórias, nas quais o início é caracterizado por um sino, símbolo histórico daquela cidade e, que de modo geral, além de marcar o tempo é muito comum a presença deste objeto nas torres das igrejas católicas. 


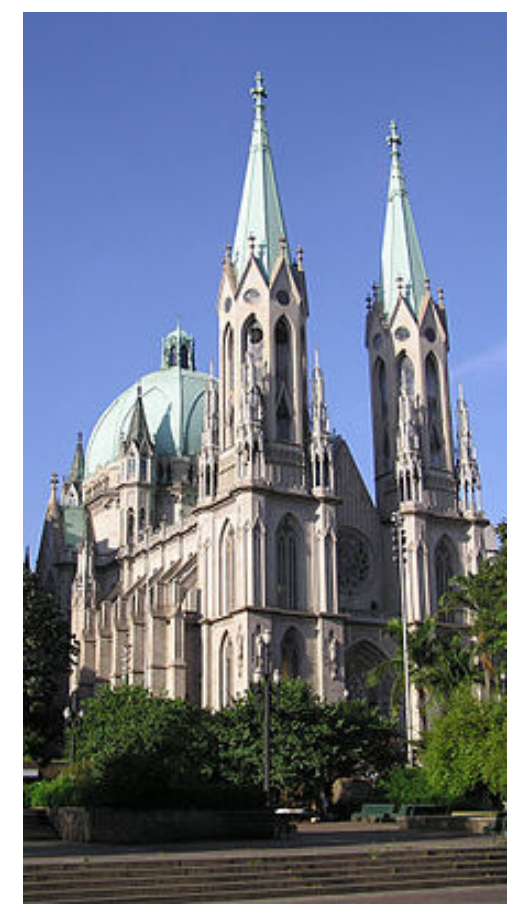

Figura 4: Vista lateral da Catedral da Sé em São Paulo

No catolicismo, o sino está localizado junto à torre da igreja. A cada hora exata ele toca marcando o registro temporal e no domingo de Páscoa, toca festivo anunciando com alegria aos devotos a ressurreição de Cristo. A influência religiosa no conceito de tempo é expressiva ao estudar-se os calendários modernos, definidos não apenas pela translação da Terra - que dá origem ao ano - mas também em função de eventos religiosos específicos a cada cultura.

No mundo ocidental, o calendário gregoriano, pois, assim, foi denominado por ter sido promulgado pelo Papa Gregório XIII, é influenciado pelo cristianismo, sendo dividido entre "antes de Cristo" (a.C.) e "depois de Cristo" (d.C.). A língua grega atual fornece dois vocábulos diferentes: Chronos "o tempo dos homens" (tempo numérico, cronológico) e Kairos "o tempo de Deus"(momento certo). A primeira refere-se ao tempo numérico, ao tempo cronológico. A segunda, 
literalmente o momento certo ou oportuno, refere-se a um conceito metafísico ou divino de tempo. Em teologia, kairos é um conceito qualitativo, em oposto ao conceito quantitativo anterior.

Em culturas como a Inca, a Maia e a Hopi, bem como culturas geograficamente distantes desta como a babilônica, grega, Zhindu, budista e jainista há o conceito de roda do tempo, em que o tempo é concebido como uma grandeza cíclica e mensurável, consistindo em eras que se sucedem para todo ser do universo entre o nascimento e a morte.

Para povos do oriente, o calendário judaico tem como ponto de partida a criação do mundo e é baseado no movimento lunar. Tanto o judaísmo quanto o cristianismo estabelecem o conceito de tempo com base na Bíblia. Assim, o tempo é considerado linear, com um começo, marcado por um ato de criação de Deus. A fé cristã também estabelece que o tempo terá fim, embora Deus seja eterno. No livro de Eclesiastes, pertencente ao velho testamento e atribuído à Salomão (970-928 a.C.), o tempo - como a palavra hebraica עדן, ¿iddan(tempo) zĕman(estação) é frequentemente traduzida - é tradicionalmente tratado como um meio para a passagem de eventos predestinados. Outra palavra, זמן "زمان zman, é associada ao ajuste de tempo, ao momento certo para cada evento ocorrer, e é usada no árabe moderno e na língua hebraica como o equivalente ao vocábulo ocidental tempo. Assim, há um tempo nomeado (zman) para cada coisa, e há um tempo distinto ('êth) para cada evento ocorrendo nos céus (Eclesiastes 3:18).

Vários povos de formas diferentes conseguiram contar o tempo e formar um calendário para poderem se orientar no seu dia a dia. Isto evidencia quão 
fundamental é o tempo para o ser humano. Observando essa importância, passamos a nos apropriar, em contextos informais, de expressões do cotidiano que apresentam uma relação metafórica com o tempo, o que concedeu organizar um quadro de metáforas com as suas relações de sentido.

\begin{tabular}{|l|l|}
\hline \multicolumn{1}{|c|}{ Estruturas Metafóricas } & \multicolumn{1}{c|}{ Sentido } \\
\hline Correr atrás do prejuízo & Perda de tempo \\
\hline Bola para frente & $\begin{array}{l}\text { Deixa-se o passado de lado e se foca no } \\
\text { futuro (tendência é a busca de sucesso) }\end{array}$ \\
\hline $\begin{array}{l}\text { Parece caranguejo caminhando para } \\
\text { trás }\end{array}$ & $\begin{array}{l}\text { Pessoa que vive de passado (tendência } \\
\text { é o fracasso) }\end{array}$ \\
\hline Chorar sobre o leite derramado & $\begin{array}{l}\text { Não adianta chorar pelo evento do } \\
\text { passado }\end{array}$ \\
\hline $\begin{array}{l}\text { Deus faz novas todas as coisas em } \\
\text { Jesus Cristo (Ap. 21:6) }\end{array}$ & $\begin{array}{l}\text { Não importa o seu passado, a sua vida } \\
\text { inicia a partir do momento que se } \\
\text { conhece a Cristo. }\end{array}$ \\
\hline A procrastinação é uma ladra & A procrastinação rouba o seu tempo \\
\hline $\begin{array}{l}\text { Não deixe para amanhã o que se pode } \\
\text { fazer hoje }\end{array}$ & Não perca seu tempo. \\
\hline
\end{tabular}

Quadro 5: Metáforas temporais

As estruturas metafóricas, relacionadas no quadro, são frases populares, que são várias vezes repetidas e se baseiam no senso comum de um determinado meio cultural. O sentido atrelado a elas não são as únicas, no entanto para esta pesquisa apenas selecionamos aquelas que foram usadas em contextos temporais. 
No início de nossa investigação, percebíamos na introdução textual maior índice de ocorrências de expressões circunstanciais, indicando principalmente tempo. Ao considerar as especificações propostas por Langacker (1987) é possível agruparmos as estruturas mais recorrentes nas redações dos candidatos em entidades semelhantes e estabelecermos uma categorização. Primeiramente, consultamos o dicionário Houaiss (2001), para conhecermos, de modo mais detido, as definição da palavra tempo.

\section{Acepção do termo Tempo}

1 duração relativa das coisas que cria no ser humano a ideia de presente, passado e futuro; período contínuo no qual os eventos se sucedem Ex.: só o t. o fará esquecer o grande amor

2 determinado período considerado em relação aos acontecimentos nele ocorridos; época

Ex.: o t. das grandes descobertas

3 certo período da vida que se distingue de outros Ex.: o t. da juventude

4 período específico, segundo quem fala, de quem se fala ou sobre quem se fala Ex.: no t. dos nossos avós a educação era mais severa

5 oportunidade para a realização de alguma coisa

Ex.: quando tiver t., pretende estudar francês

6 conjunto de condições meteorológicas

Ex.: a previsão do t. indica fortes chuvas

7 época propícia para certos fenômenos ou atividades; estação, sazão, quadra Exs.: t. do plantio

t. de festas

8 Rubrica: esportes. cada um dos períodos em que se dividem as partidas de determinados jogos

9 Rubrica: esportes. duração cronometrada de uma corrida Ex.: aquele atleta fez um bom $t$.

10 Rubrica: física. dimensão que permite identificar dois eventos que, caso contrário, seriam idênticos e que ocorrem no mesmo ponto do espaço [símb.: T]

11 Rubrica: gramática. categoria verbal que indica o momento em que se dá o fato expresso pelo verbo [O conteúdo dessa categoria varia segundo as línguas; em português, compreende presente, pretérito (ou passado) e futuro, e suas subdivisões.]

12 Rubrica: gramática. cada subdivisão da categoria tempo, existente numa língua, e seu paradigma próprio Exs.: t. presente tempos do subjuntivo

13 Rubrica: música. 
unidade abstrata de medida do tempo musical, a partir da qual se estabelecem as relações rítmicas; pulsação

14 Rubrica: música.

m.q. ANDAMENTO ('velocidade das pulsações')

\section{Etimologia}

lat. tempus,òris 'tempo, tempo prosódico, quantidade de uma sílaba

Quadro 6: Acepções de Tempo (HOUAISS, 2001)

Mesmo conhecendo as diferentes acepções de tempo, muitas vezes, há dificuldade e incerteza em categorizar termos como, "no mundo atual", em nossa sociedade atual", "em uma sociedade que fala" e etc. Poderiam essas expressões serem categorizadas em tempo ou em espaço? Espaço e lugar são as mesmas categorias linguísitcas? Diante desses questionamentos, fomos procurar entender mais sobre a categoria a cognitiva espacial. Então, decidimos iniciar com alguns conceitos sobre espaço.

\subsection{Espaço: Explorando conceitos}

A teoria da relatividade considera $\operatorname{espaço~}^{26}$ e tempo uma entidade geométrica unificada. No corpus analisado, semelhantemente ao que ocorre nessa teoria, temos observado que os alunos fazem referências locativas, unindo o tempo à categoria espaço; a exemplo disso, é a expressão "No Brasil atualmente", retirada de uma das redações. Dada a proximidade dessas duas categorias, entendemos

\footnotetext{
${ }^{26}$ Espaço na teoria da relatividade tem sinônimo de lugar, ou seja, localização geográfica.
} 
que a categoria espaço mereça a nossa atenção. Iniciemos pelo quadro de acepções que é apresentado por Houaiss (2001):

Acepção do termo Espaço

substantivo masculino

1 extensão ideal, sem limites, que contém todas as extensões finitas e todos os corpos ou objetos existentes ou possíveis

2 medida que separa duas linhas ou dois pontos

3 extensão limitada em uma, duas ou três dimensões; distância, área ou volume determinados

Ex.: <0 e. era pequeno para a construção do prédio $><0$ e. interior era aconchegante $>$

4 a extensão que compreende o sistema solar, as galáxias, as estrelas; o Universo

5 região situada além da atmosfera terrestre, ou além do sistema solar

Ex.: o foguete avançava no e.

6 Derivação: sentido figurado. extensão abstrata, indefinida, de significado subjetivo

Ex.: ficou ali, desnorteado, os olhos perdidos no e.

7 capacidade, acomodação

Ex.: há e. para todos no auditório

8 cabimento, oportunidade

Ex.: não havia e. para aquele tipo de comportamento

9 período ou intervalo de tempo

Ex.: num e. de dois meses escreveu o livro

10 demora, delonga

Ex.: precisava de mais e. para desenvolver sua tese

11 campo abrangido idealmente por determinada área dos conhecimentos e fazeres humanos

Ex.: e. cultural, e. psicológico, e. literário

12 Rubrica: editoração.

o claro que constitui a separação entre as palavras de uma linha em texto impresso ou manuscrito

13 Rubrica: filosofia.

no Kantismo, forma intuitiva e apriorística a partir da qual a sensibilidade humana organiza a experiência sensorial, estabelecendo relações e distâncias entre objetos percebidos simultaneamente

14 Rubrica: física.

característica geométrica de um universo no qual ocorrem fenômenos físicos e que permite a extensão destes fenômenos em direções mutuamente ortogonais

15 Rubrica: artes gráficas.

peça menos alta que os tipos, us. para produzir pequenos claros em uma linha de composição

16 Rubrica: artes gráficas.

peça em forma de anel que é encaixada entre os discos da máquina de pautar, para 
produzir o espaço claro entre duas linhas

Obs.: cf. ${ }^{1}$ disco

17 Rubrica: matemática.

termo genérico que designa um conjunto com determinadas operações

18 Rubrica: música.

o claro entre duas linhas consecutivas da pauta; entrelinha

$\square$ adjetivo

Regionalismo: Nordeste do Brasil, Minas Gerais.

19 que tem chifres muito abertos, espaçados (diz-se de bovino)

Obs.: f. não pref.: ${ }^{1}$ espácio

\section{Etimologia}

lat. spatìum, ií 'espaço livre, extensão, distância, intervalo'; emprega-se tb. na acp. temporal 'espaço de tempo, duração, época, tempo; esp. lugar de passeio, passeio, carreira, pista'; ver espac-

Quadro 7: Acepões da palavra espaço (HOUAISS, 2001)

Já pelo número de acepções apresentadas por Houaiss é possível inferir que compreender o conceito de espaço é tentar encontrar a ponta do novelo embaraçado a uma série de conceitos que muitas vezes se opõem. Podemos verificar tal oposição, por exemplo, nas entradas 1 e 3 do dicionário, enquanto na primeira a definição é de uma extensão sem limites, na segunda a extensão é limitada. Também nos chama a atenção a entrada de número 6 que defini espaço em uma "extensão abstrata, indefinida, de significado subjetivo", este conceito nos faz refletir se se trata de uma extensão abstrata, então espaço e lugar são diferentes, já que nesta tese, lugar é concebido como localização geográfica. Já a entrada de número 9 define espaço em "período ou intervalo de tempo", isso demonstra que há uma linha tênue entre as categorias tempo e espaço.Toda a problemática relativa ao espaço pode ser esquematicamente estudada sob o ponto de vista objetivo e subjetivo, representado respectivamente pelo aspecto: 
(i) Ontológico: (objetivo) no qual o ser é concebido como tendo uma natureza comum que é inerente a todos e a cada um dos seres;

(ii) Psicológico: (subjetivo) estudo do comportamento e dos processos mentais.

$\mathrm{Na}$ abordagem ontológica, é impossível conceber o Espaço e o Tempo independentemente do eu, como é também impossível conceber o eu senão como fruto da vivência do espaço e do tempo: "Je temps a son entre dans Le présent de l'instante de parole (...). Ce présent est réinventé chaque fois qu'un homme parle". (Benveniste, 1966)

$\mathrm{Na}$ abordagem psicológica, o espaço é compreendido sob duas direções possíveis: a genética e a nativista. Para a geneticista, a noção de espaço é o resultado de um processo psicológico com origem na consciência empírica das realidades singulares extensas, partindo daí a ideia genérica de extensão. Para os nativistas, a noção de espaço é constituinte essencial do espírito, devendo considerar-se como pertencente, desde início, ao indivíduo $\mathrm{Da}$ abordagem psicológica a dificuldade é saber se tal noção é visual, tátil uma síntese das duas, ou ainda determinar em que medida se efetua tal síntese.

A Filosofia é a área do saber que se apresenta mais transparente para discutir o conceito de espaço sob a abordagem ontológica e psicológica. Na tradição filosófica ocidental houve correntes que pensaram que a ideia de espaço é tão cheia de contradições que não tem valor objetivo. Por outro lado, houve também realistas, que the atribuíram uma realidade independente ou os que acreditaram que o espaço era uma qualidade real dos objetos de experiência e uma relação real dos objetos, mas que se recusaram a conceder-lhe estatuto. Para os defensores desta última doutrina, o espaço puro é uma abstração sem existência real. (Batoreo, 2000, 32-33) 
Ultrapassando a concepção aristotélica de espaço e de tempo e defendendo a ideia do espaço anterior às coisas e com a ideia do tempo como conjunto subjetivo de fenômenos ordenados, os filósofos do renascimento entenderam espaço como uma espécie de "continente universal"dos corpos físicos. Este espaço era homogêneo (indiscernível), isotrópico (todas as direções do espaço tinham as mesmas propriedades, contínuo ilimitado, tridimensional e homoloidal (uma dada figura era matriz de um número infinito de figuras em diferentes escalas, similares uma às outras)

Segundo Aristóteles tudo que tem tamanho é corpo, ou algo semelhante a um corpo, de tal forma que não pode existir em um mesmo lugar, mais que um corpo ao mesmo tempo. Logo, para Aristóteles,, não há possibilidade de interpenetração dos corpos.

Por outro lado, Descartes opõe-se às ideias de Aristóteles, pois não acredita na ideia de um espaço separado por corpos, com isso defendia que a extensão corpórea e a extensão espacial eram a mesma coisa. Extensão é tudo que o corpo é, e o pensamento é tudo que a alma é. Do mesmo modo que os corpos eram concebidos como extensão, o espaço supostamente vazio teria que sê-lo, uma vez que não haveria diferença entre a extensão de um corpo e a extensão do espaço; portanto só pode ter extensão aquilo que contém alguma substância. ${ }^{27}$

Espaço começaria com a explicação do que seria substância extensa, o corpo extenso. A extensão ou a quantidade, dotada de altura, largura e

\footnotetext{
27 Substância, na visão de Descartes, conforme descrito em Les principles de la philosophie , era a primeira categoria de "ser"existente no mundo. Existiram dois tipos de substâncias: a corpórea ou extensa e a espiritual ou pensante. A primeira se revela na largura, altura e profundidade que pertence ao corpo, isto é, a substância extensa era o próprio corpo e este era uma parte do espaço. A segunda são, por exemplo, as ideias, a vontade, a imaginação, o entendimento.
} 
profundidade pertenceria a todo e qualquer corpo tornando o plenum, eliminando qualquer possibilidade de existência de posições espaciotemporais sem matéria ${ }^{28}$. Logo, espaço e corpo ${ }^{29}$ são uma coisa só.

Entender espaço como lugar é assumir no continuum das categorias cognitivas o conceito mais básico apresentado por Aristóteles, no entanto como vimos a partir do estudo realizado pelo filósofo Descartes, tal conceito passou por um amadurecimento científico, nos levando entender que espaço é uma extensão das categorias mais concretas.

Por fim retomamos as ideias de Albert Einstein que, com sua teoria da relatividade, defende que tempo e espaço são relativos e estão profundamente entrelaçados. Ainda que estejamos em nosso quarto dormindo em uma cama, estamos nos movendo na dimensão temporal, afinal os segundos estão passando. Por fim, apresentamos um quadro com os conceitos resumidos:

\begin{tabular}{|c|c|c|}
\hline \multicolumn{3}{|r|}{ Conceitos de ESPAÇO } \\
\hline \multirow{3}{*}{$\frac{d}{\underset{\alpha}{\alpha}}$} & $\begin{array}{l}\text { Espaço } \\
\text { geográfico }\end{array}$ & qualquer região ou fração de espaço do planeta. \\
\hline & $\begin{array}{l}\text { Espaço } \\
\text { público }\end{array}$ & o meio físico que é de uso comum e posse coletiva \\
\hline & $\begin{array}{l}\text { Espaço } \\
\text { (sinal) }\end{array}$ & $\begin{array}{l}\text { um caractere invisível, representado por um intervalo } \\
\text { unitário vazio }\end{array}$ \\
\hline \multirow{2}{*}{$\frac{0}{\mathscr{D}}$} & $\begin{array}{l}\text { Espaço } \\
\text { físico }\end{array}$ & o meio físico que nos envolve \\
\hline & Espaço & o meio físico do universo \\
\hline
\end{tabular}

\footnotetext{
${ }^{28}$ A ideia de vácuo para Descartes era tão incoerente quanto a ideia de um átomo indivisível, uma vez que o corpo era extenso, tudo estaria tomado por corpos (isso explica a boca e o fundo de um vaso não se juntarem).

${ }^{29}$ Descartes defende o corpo sendo uma substância extensa, que se revelava através de sua largura, altura e profundidade.
} 


\begin{tabular}{|c|c|c|}
\hline & sideral & \\
\hline & $\begin{array}{l}\text { Espaço- } \\
\text { tempo }\end{array}$ & um sistema de coordenadas \\
\hline \multirow{6}{*}{$\frac{\mathbb{J}}{\underset{E}{\mathbf{E}}}$} & $\begin{array}{l}\text { Espaço } \\
\text { compacto - }\end{array}$ & um tipo de espaço topológico \\
\hline & $\begin{array}{l}\text { Espaço } \\
\text { euclidiano }\end{array}$ & um tipo de espaço vetorial \\
\hline & $\begin{array}{l}\text { Espaço de } \\
\text { Hilbert }\end{array}$ & uma generalização do espaço euclidiano \\
\hline & $\begin{array}{l}\text { Espaço } \\
\text { matemático }\end{array}$ & uma estrutura algébrica similar à de um conjunto \\
\hline & $\begin{array}{l}\text { Espaço } \\
\text { topológico }\end{array}$ & $\begin{array}{l}\text { uma estrutura matemática formada por um par conjunto- } \\
\text { topologia }\end{array}$ \\
\hline & $\begin{array}{l}\text { Espaço } \\
\text { vetorial }\end{array}$ & $\begin{array}{l}\text { uma entidade matemática formada por um conjunto de } \\
\text { vetores, um corpo e uma operação entre os dois }\end{array}$ \\
\hline
\end{tabular}

Quadro 8: Conceitos de espaço por áreas

No quadro, é possível reconhecer quão vasto são os conceitos de espaço de acordo com as diferentes áreas. No entanto, ainda é preciso conhecê-lo do ponto de vista da linguística. Então, passaremos a discutir acerca das categorias cognitivas tal como proposta por Heine, Claudi e Hünnemeyer (1991, 1991b) e já mencionados no capítulo de fundamentação teórica.

As categorias cognitivas estão relacionadas ao conceito de metáforas, pois são as transferências metafóricas que contribuem para o desenvolvimento das categorias gramaticais expressarem funções mais abstratas. Tais categorias, segundo Heine, Claudi e Hünnemeyer (1991), podem ser arrumadas na seguinte escala: pessoa $>$ objeto $>$ processo $>$ espaço $>$ tempo $>$ qualidade $^{30}$. No entanto precisamos considerar algumas questões básicas.

\footnotetext{
${ }^{30}$ Essa trajetória proposta pelos autores foi questionada em Lima-Hernandes (2009)
} 
Primeiro, cada uma dessas categorias constituem domínios cognitivos ou conceituais, denominados grupos de conhecimentos estruturados, que representam mentalmente a forma de organizarmos o mundo. Segundo, a relação desses domínios são metafóricas, o que significa que quaisquer dos domínios podem conceituar categorias à direita. Se observarmos as expressões: "na mesa", "na sala", "no Brasil", "no mundo" e "na sociedade", reconhecemos o traço semântico de limitação de extensão (mais concreto), até a ilimitação da extensão, fator que o terna mais abstrato. Logo, percebemos uma escala que varia do termo mais concreto (na mesa) ao mais abstrato (na sociedade). Já de posse das ideias gerais do termo espaço passaremos ao capítulo III, no qual serão apresentados os procedimentos técnicos e científicos. 


\section{CAPÍTULO III}

\section{Procedimentos Técnicos e Científicos}

"Os métodos são as verdadeiras riquezas."

(Friedrich Nietzsche)

Nesta seção, discorreremos sobre os encaminhamentos metodológicos levando em consideração fundamentos teóricos já apresentados, dos quais resgataremos critérios de análise (vide seção 3.2). Antecede essa tarefa a exposição do modo como reunimos amostras para compor o corpus de análise, que é prioritariamente composto pelas redações do vestibular da FUVEST, instituição que nos cedeu o material do período de 2004 a 2011 para estudo. Isso será exposto na seção 3.1, em que também apresentaremos as propostas temáticas de cada ano. Na seção 3.3, explanaremos a forma de depreensão dos padrões de uso introdutório entre os quais selecionaremos o mais recorrente para um estudo verticalizado. Ainda nessa seção, apresentaremos as estratégias adotadas para a referendação de usos.

\subsection{Caracterizando o corpus}

$\checkmark$ Conhecendo a Fundação Universitária para o Vestibular - FUVEST

A FUVEST é responsável pela preparação das provas dos candidatos às vagas da Universidade de São Paulo - USP, principalmente. Essa instituição (USP) 
é alvo de muitos jovens que sonham em ingressar no ensino superior. Por conta disso, apresenta alto índice de concorrência em seus vestibulares.

Compõe o perfil dos candidatos a seguinte característica: em geral, são estudantes que, para enfrentar a concorrência, se preparam durante ou após o ensino médio em cursos específicos de vestibular ${ }^{31}$. Tais cursos trabalham um vasto conteúdo, que é, em tese, fonte para a resolução das questões integrantes das provas vestibulares.

A prova da FUVEST é dividida em primeira e segunda fases. O candidato aprovado no primeiro momento da avaliação selecionadora, que envolve apenas questões objetivas, participará da segunda fase, que é dissertativa e que dela faz parte a redação. Nesse momento, os candidatos estão em uma situação de grande tensão, já que estão concorrendo com os melhores por uma vaga. Ademais, a ansiedade, o desejo e a emoção - fatores emocionais tratados por Damásio (2011), conforme vimos na seção da Fundamentação Teórica -, em geral, afetam a produção linguística. Esses aspectos nos levaram a escolher as redações da FUVEST como corpus de trabalho.

\section{$\checkmark$ As Propostas da FUVEST}

Neste ponto, explicitamos as propostas temáticas dos anos de 2004 a 2011 para identificarmos, durante as análises desenvolvidas no capítulo IV, evidências de que o candidato utiliza produtivamente sua bagagem discursivo-pragmática para a

\footnotetext{
${ }^{31}$ Esses cursos, popularmente conhecidos como "cursinhos", em sua maioria, são muito mais conteudistas do que o próprio ensino médio, o que descaracteriza o termo "cursinho".
} 
construção de sua tese, o que configuraria alto índice de autoria. Em um nível mais baixo de autoria, esse candidato utilizaria - hipotetizamos - excertos dos textos que integram as propostas. Num índice mais baixo de autoria, ainda que manifeste ponto de vista, recorre às expressões temporais, ou ainda estabelecem diálogo com outros textos próprios de seu conhecimento.

Saber em que medida esse índice de autoria interfere no conteúdo e na construção expressa no primeiro parágrafo constitui-se objeto desta pesquisa. Para evitar enviesamentos analíticos, procederemos à leitura das propostas e hipotetizaremos tendências de categorias cognitivas propícias à tese, condicionadas naturalmente pelo conteúdo dos textos das propostas.

\section{FUVEST 2004}

Nos três textos abaixo, manifestam-se diferentes concepções do tempo; o autor de cada um deles expõe uma determinada relação com a passagem do tempo.

Leia-os com atenção:

\section{Texto I}

Mais do que nunca a história é atualmente revista ou inventada por gente que não deseja o passado real, mas somente um passado que sirva a seus objetivos. (...) Os negócios da humanidade são hoje conduzidos especialmente por tecnocratas, resolvedores de problemas, para quem a história é quase irrelevante; por isso, ela passou a ser mais importante para nosso entendimento do mundo do que anteriormente.

Eric Hobsbawm, Tempos interessantes: uma vida no século XX

\section{Texto II}

O que existe é o dia-a-dia. Ninguém vai me dizer que o que aconteceu no passado tem alguma coisa a ver com o presente, muito menos com o futuro. Tudo é hoje, tudo é já. Quem não se liga na velocidade moderna, quem não acompanha as mudanças, as descobertas, as conquistas de cada dia, fica parado no tempo, não entende nada do que está acontecendo.

(Herberto Linhares, depoimento)

\section{Texto III}




\author{
Não se afobe, não, \\ Que nada é pra já, \\ O amor não tem pressa, \\ Ele pode esperar em silêncio \\ Num fundo de armário, \\ Na posta-restante, \\ Milênios, milênios \\ No ar ... \\ E quem sabe, então, \\ O Rio será \\ Alguma cidade submersa. \\ Os escafandristas virão \\ Explorar sua casa, \\ Seu quarto, suas coisas, \\ Sua alma, desvãos ... \\ Sábios em vão \\ Tentarão decifrar \\ O eco de antigas palavras, \\ Fragmentos de cartas, poemas, \\ Mentiras, retratos, \\ Vestígios de estranha civilização. \\ Não se afobe, não, \\ Que nada é pra já, \\ Amores serão sempre amáveis. \\ Futuros amantes quiçá \\ Se amarão, sem saber, \\ Com o amor que eu um dia \\ Deixei pra você. \\ (Chico Buarque, "Futuros amantes")
}

Nessa proposta, o primeiro texto trata do estatuto da história como dinâmica

temporal, o segundo reflete a angústia e a fugacidade do tempo e o terceiro "canta" a fluidez das relações. Todos esses textos projetam as categorias de tempo e de espaço como fundo de discussão. Verificaremos se essa constatação ganha eco na análise dos primeiros parágrafos.

\title{
FUVEST 2005
}

Considere a foto e os textos abaixo: 


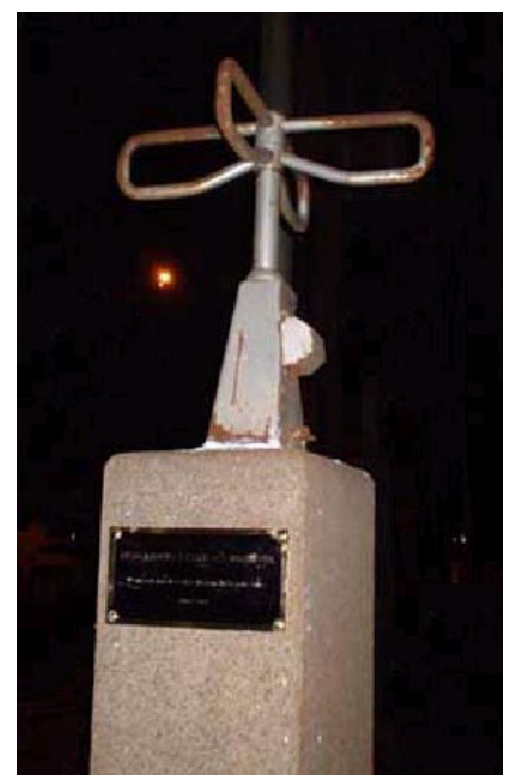

Crédito foto: Jefferson Coppola / Folha Imagem (03/09/04)

\section{"Catraca invisível" ocupa lugar de estátua}

Sem que ninguém saiba como - e muito menos o por quê - uma catraca enferrujada foi colocada em cima de um pedestal no largo do Arouche (centro de São Paulo). É o "monumento à catraca invisível", informa uma placa preta com moldura e letras douradas, colocada abaixo do objeto, onde ainda se lê: "Programa para a descatracalização da vida, Julho de 2004". (Foto acima) Adaptado de Folha de S. Paulo

[Catraca $=$ borboleta: dispositivo geralmente formado por três ou quatro barras ou alças giratórias, que impede a passagem de mais de uma pessoa de cada vez, instalado na entrada e/ou saída de ônibus, estações, estádios etc. para ordenar e controlar o movimento de pessoas, contá-las etc.]

\section{Grupo assume autoria da "catraca invisível"}

Um grupo artístico chamado "Contra Filé" assumiu a responsabilidade pela colocação de uma catraca enferrujada no largo do Arouche (região central). A intervenção elevou a catraca ao status de monumento "à descatracalização da vida" e fez parte de um programa apresentado no Sesc da Avenida Paulista, paralelamente ao Fórum das Cidades. No site do Sesc, o grupo afirma que a catraca representa um objeto de controle "biopolítico" do capital e do governo sobre os cidadãos.

\section{Adaptado de Folha de S. Paulo}

Em site sobre o assunto, assim foi explicado o projeto do grupo "Contra Filé": "O 'Contra Filé' desenvolveu o PROGRAMA PARA A DESCATRACALIZAÇÃO DA PRÓPRIA VIDA. A catraca representa um signo revelador do controle biopolítico, através de forças visíveis e/ou invisíveis. Por quantas catracas passamos diariamente? Por quantas não passamos, apesar de termos a sensação de passar?"

(http://lists.indymedia.org/pipemail/cmi-brasil-video/2004-july/0726-ct.html) 
$\mathrm{Na}$ proposta de 2005, apresenta-se uma catraca similar a de ônibus, como forma de criticar o bloqueio ao movimento espacial, que é metaforicamente assumido como um controle ideológico no segundo texto. Esperamos que os textos produzidos projetem como tese a categoria espacial, já que estes conduzem à discussão da dinamicidade de pessoas em lugares físicos diversos, em um contexto ideológico que caminha para o espaço.

\section{Texto 1}

\section{FUVEST 2006}

O trabalho não é uma essência atemporal do homem. Ele é uma invenção histórica e, como tal, pode ser transformado e mesmo desaparecer.

Adaptado de A.Simões

\section{Texto 2}

Há algumas décadas, pensava-se que o progresso técnico e o aumento da capacidade de produção permitiriam que o trabalho ficasse razoavelmente fora de moda e a humanidade tivesse mais tempo para si mesma. Na verdade, o que se passa hoje é que uma parte da humanidade está se matando de tanto trabalhar, enquanto a outra parte está morrendo por falta de emprego.

M.A. Marques

\section{Texto 3}

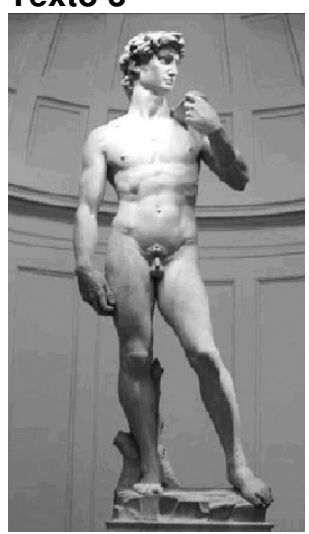

O trabalho de arte é um processo. Resulta de uma vida. Em 1501, Michelangelo retorna de viagem a Florença e concentra seu trabalho artístico em um grande bloco de mármore abandonado. Quatro anos mais tarde fica pronta a escultura "David". 
$\mathrm{Na}$ proposta de 2006, as ideias de transformação e de mudança perpassam os

três textos motivadores. Isso conduz a uma construção de tese baseada no tempo e espaço, pois só eles sugerem mudança e transformação.

\section{FUVEST 2007}

Em primeiro lugar (...), pode-se realmente "viver a vida" sem conhecer a felicidade de encontrar num amigo os mesmos sentimentos? Que haverá de mais doce que poder falar a alguém como falarias a ti mesmo? De que nos valeria a felicidade se não tivéssemos quem com ela se alegrasse tanto quanto nós próprios? Bem difícil te seria suportar adversidades sem um companheiro que as sofresse mais ainda.

(...)

Os que suprimem a amizade da vida parecem-me privar o mundo do sol: os deuses imortais nada nos deram de melhor, nem de mais agradável.

Cícero, Da amizade.

Aprecio no mais alto grau a resposta daquele jovem soldado, a quem Ciro perguntava quanto queria pelo cavalo com o qual acabara de ganhar uma corrida, e se o trocaria por um reino: "Seguramente não, senhor, e no entanto eu o daria de bom grado se com isso obtivesse a amizade de um homem que eu considerasse digno de ser meu amigo". E estava certo ao dizer se, pois se encontramos facilmente homens aptos a travar conosco relações superficiais, o mesmo não acontece quando procuramos uma intimidade sem reservas. Nesse caso, é preciso que tudo seja límpido e ofereça completa segurança.

Montaigne, "Da amizade" (adaptado).

Amigo é coisa pra se guardar,

Debaixo de sete chaves,

Dentro do coração...

Assim falava a canção

Que na América ouvi...

Mas quem cantava chorou,

Ao ver seu amigo partir...

Mas quem ficou,

No pensamento voou,

Com seu canto que o outro lembrou.

(...)

Fernando Brant / Milton Nascimento,

"Canção da América".

(...)

E sei que a poesia está para a prosa

Assim como o amor está para a amizade.

E quem há de negar que esta lhe é superior?

(...)

Caetano Veloso, "Língua". 


\title{
Na FUVEST de 2007, prioriza-se a dinâmica espaço-temporal das relações
}

\author{
humanas de afeto. Acreditamos que essas dinâmicas propiciam a topicalização dessas
}

categorias como fundo para a tese.

\section{FUVEST 2008}

\section{REDAÇĀO}

Vigiläncia epistémica* e a preocupaçäo que todos nós deveriamos ter com relação a tudo o que lemos, ouvimos e aprendemos de outros seres humanos, paranáo sermos enganados, para néo acreditarmos em tudo a que ế escrito e dito par ai. É preciso vigiar a futum para satermas separar a join do trign *

Hoje hoo parte dhs sifes de hisca insexam tudh a que encontram pela frente di intemet, mesmo que se trate de uma grande bobagem ou de evidente inverdade. Qualouer opiniāo emitida. vista como um dreto de todos, $\boldsymbol{e}$ divulgada aos quatro cantos do mundo. De tato, alquns desses sites de busca deveriam colocar, nos primeires tuqares, páginas de renomadas Universidades, preocupadas com a verdade.

Tcolos precisamos estar muifo atentos a dois aspectos com relacāo a tudo o que ouvinos e lemos:

- se quem nos fala ou escreve conhece a fundo o assunto, se é um especialisia comprovado, se sabe do que está fatando

- se quem nos fala ou escreve, na verdade, é um idiota que ouviu falar algo e simplesmente repassa, aos outros, oque leu e ouviu, sem acrescentar absolutamente nada de úti.

Aumentar nossa vigilancia e preocupaçăo com a verdade é necessidacle cada vez mais premente num tempo que todos os quns chamam de Era de infomaçäo.

Discordo, protundamente, desses guis. Estemos, na reafidade, na Era đá Desinformaçāo, do tanio txo e ruido sem significado que, na maior parte das vezes, nos sao transmitidos, todos os dias, eletronicamente, sem que exista o menor cuidado com a precisalo e seriedale do que se enite, por pate das fontes que colocan matétas na rede. $E$ mais uma consequencia dessa ideia que a maioria das pessoas tem sobre a liberdade de expressar o que ben quiser, de expressar qualquer opināa que seja, como se opinióes năo precisassem se basear no rigor cientifico, antes de serem emitidas

Stephen Kantz, Revista Veja 03/102007, Adjotado

- Viqilància episténica = capacidade de ficar atento e perce ber so uma afimaçăo tem ou năo valor cion tifíco.

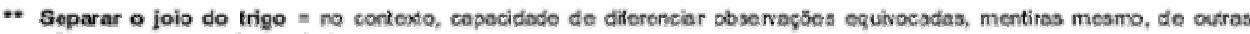
afrmagiese quie cantím verdades

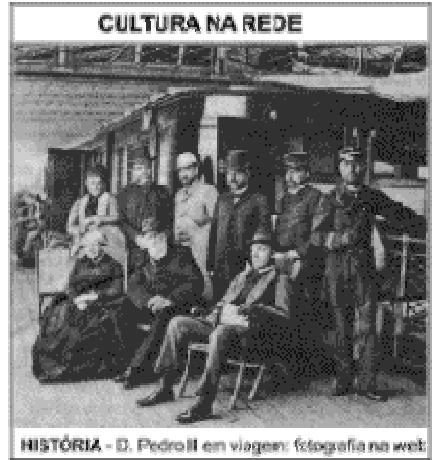

textos explicat segunda fase, será possivel consultar limros.

A Biblioteca Nacionai brasileira é uma das participantes

o Eatado de S. Faulo, Daltoroor. Adepledo.
0 acesso a Informaço lem stra maioria eletronica) se tomou o direlto humano mais zelosamente defendidc. E aquiho sobre o que a inbornaçäo mais informa é a fluidez do mundo habitado e a tlexibiildade dos habitantes. 0 noticiario - essa parte da infomaça eletronica que tem maior chance de ser confundrda con a vendadeira representacalo do mundo la tora ef dos mais perecivels bens da eletronica. Mas a perecibilidade dos noticlários como informaçăo sobre o mundo roal, $b \mathrm{em}$ si mosma uma mportante informaçéo: a transmissabo das noticias é a celebraçāo constante $\theta$ diariamente repetida da enorme velocidade da mudança, do aceierado envelhecimento e da perpetuidade dos nowos comecos.

$$
\begin{array}{r}
\text { Zygmunt Beumen. Modernidede Liquide. } \\
\text { Adaptado. }
\end{array}
$$

Instruçăo: Os textos apresentados traem reflexôes e noticias sobre o mundo digital. Com base nesses textos $\mathrm{s}$ em outras informaçōes e idélas que julgar pertinentes, redija uma DIS SEFTACÃO EM PROSA, argumertando de mode clare e coerente. 
$\mathrm{Na}$ proposta de 2008, o assunto da tecnologia é discutido sob a perspectiva temporal da atualidade para a perspectiva de futuro. Focaliza-se a temática do mundo digital, em especial, demonstrando a velocidade da mudança, principalmente explicitado pela matéria do Jornal O Estado de São Paulo, texto motivador da proposta. As categorias de tempo e de espaço novamente revelam-se prioritárias para a construção de uma tese que seja suficiente para a argumentação solicitada pela FUVEST.

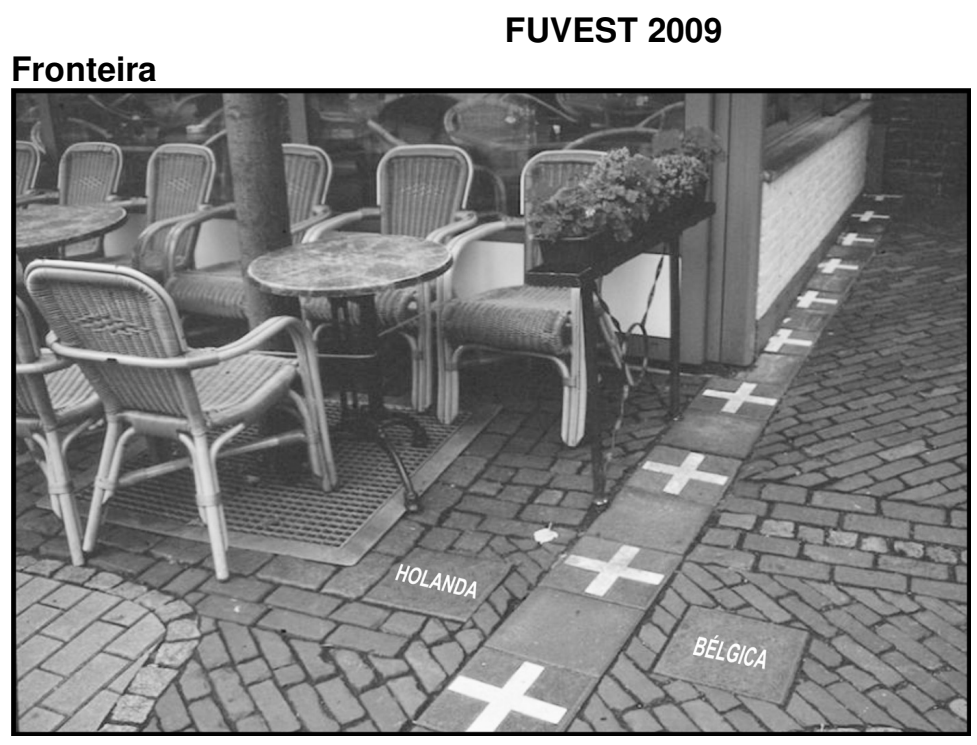

Fonte: http://pt.wikipedia.org/wiki/Imagem:BaarleNassau_fronti\%C3\%A8re_caf\%C3\%A9.jpg, 30/06/2008.

substantivo feminino 1 parte extrema de uma área, região etc., a parte limítrofe de um espaço em relação a outro. Ex.: Havia patrulhas em toda a f.

2 o marco, a raia, a linha divisória entre duas áreas, regiões, estados, países etc. Ex.: O rio servia de f. entre as duas fazendas.

3 Derivação: por extensão de sentido. o fim, o termo, o limite, especialmente do espaço. Ex.: Para a ciência, o céu não tem f. 
4 Derivação: sentido figurado. o limite, o fim de algo de cunho abstrato. Ex.: Havia chegado à f. da decência.

Fonte: Dicionário Houaiss da Língua Portuguesa. Adaptado.

As fronteiras geográficas são passíveis de contínua mobilidade, dependendo dos movimentos sociais e políticos de um ou mais grupos de pessoas. Além do significado geográfico, físico, o termo "fronteira" é utilizado também em sentido figurado, especialmente, quando se refere a diferentes campos do conhecimento. Assim, existem fronteiras psicológicas, fronteiras do pensamento, da ciência, da linguagem etc.

Com base nas idéias sugeridas acima, escolha uma ou até duas delas, como tema, e redija uma dissertação em prosa, utilizando informações e argumentos que dêem consistência a seu ponto de vista.

No ano de 2009, tematiza-se a transformação de concepção de limite geográfico, significando muito mais uma segregação e distanciamento do que o sentido mais recente e mais abstrato de ponto de articulação e de diálogo com outras áreas de reflexões. Intuímos que a tese seja fundada na categoria espacial, na maioria das teses das dissertações produzidas nesse ano.

\section{FUVEST 2010}

\section{Um mundo por imagens}

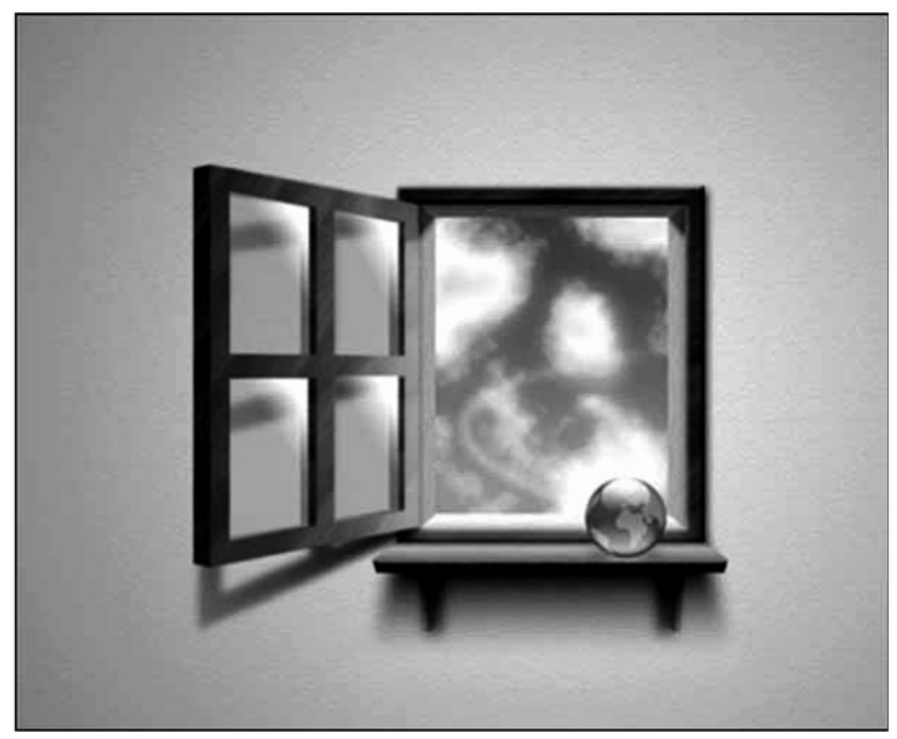


http://www.imotion.com.br/imagens/data/media/83/4582janela.jpg.

Acessado em 15/10/2009

A imaginação simbólica é sempre um fator de equilíbrio. O símbolo é concebido como uma síntese equilibradora, por meio da qual a alma dos indivíduos oferece soluções apaziguadoras aos problemas.

Gilbert Durand.

Ao invés de nos relacionarmos diretamente com a realidade, dependemos cada vez mais de uma vasta gama de informações, que nos alcançam com mais poder, facilidade e rapidez. É como se

ficássemos suspensos entre a realidade da vida diária e sua representação.

Tânia Pellegrini. Adaptado.

$\mathrm{Na}$ civilização em que se vive hoje, constroem-se imagens, as mais diversas, sobre os mais variados aspectos; constroem-se imagens, por exemplo, sobre pessoas, fatos, livros, instituições e situações. No cotidiano, é comum substituir-se o real imediato por essas imagens. Dentre as possibilidades de construção de imagens enumeradas acima, em negrito, escolha apenas uma, como tema de seu texto, e redija uma dissertação em prosa, lançando mão de argumentos e informações que deem consistência a seu ponto de vista.

Os textos motivadores da FUVEST de 2010 explanam a representação de espaços simbólicos capitaneados por uma imagem de uma janela aberta para o infinito. Hipotetizamos que essa mesma transposição de espaço ganhe representação simbólica na construção da tese.

\section{FUVEST 2011}

Observe esta imagem e leia com atenção os textos abaixo.

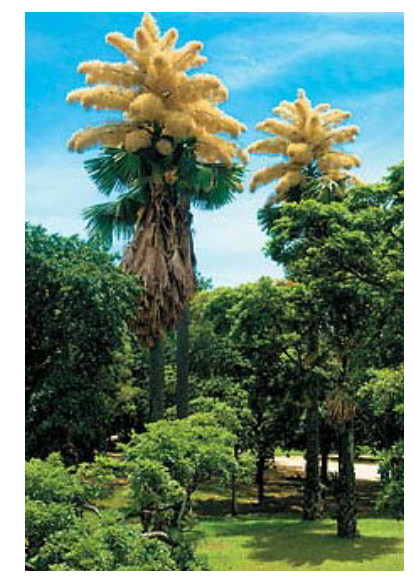




\section{Texto 1}

Um grandioso e raro espetáculo da natureza está em cena no Rio de Janeiro. Trata-se da floração de palmeiras Corypha umbraculifera, ou palma talipot, no Aterro do Flamengo. Trazidas do Sri Lanka pelo paisagista Roberto Burle Marx, elas florescem uma única vez na vida, cerca de cinquenta anos depois de plantadas. Em seguida, iniciam um longo processo de morte, período em que produzem cerca de uma tonelada de sementes.

http://veja.abril.com.br, 09/12/2009. Adaptado.

\section{Texto 2}

Quando Roberto Burle Marx plantou a palma talipot, um visitante teria comentado: "Como elas levam tanto tempo para florir, o senhor não estará mais aqui para ver". O paisagista, então com mais de 50 anos, teria dito: "Assim como alguém plantou para que eu pudesse ver, estou plantando para que outros também possam contemplar".

http://www.abap.org.br. Paisagem Escrita. no 131, 10/11/2009. Adaptado.

\section{Texto 3}

Onde não há pensamento a longo prazo, dificilmente pode haver um senso de destino compartilhado, um sentimento de irmandade, um impulso de cerrar fileiras, ficar ombro a ombro ou marchar no mesmo passo. A solidariedade tem pouca chance de brotar e fincar raízes. Os relacionamentos destacam-se sobretudo pela fragilidade e pela superficialidade.

Z. Bauman. Vidas desperdiçadas. Rio de Janeiro: Jorge Zahar, 2005.

Adaptado.

\section{Texto 4}

A cultura do sacrifício está morta. Deixamos de nos reconhecer na obrigação de viver em nome de qualquer coisa que não nós mesmos.

G. Lipovetsky, cit. por Z. Bauman, em A arte da vida. Rio de Janeiro: Jorge Zahar, 2009.

Como mostram os textos 1 e 2, a imagem de abnegação fornecida pela palma talipot, que, de certo modo, "sacrifica" a própria vida para criar novas vidas, é reforçada pelo altruísmo* de Roberto Burle Marx, que a plantou, não para seu próprio proveito, mas para o dos outros. Em contraposição, o mundo atual teria escolhido o caminho oposto.

Com base nas ideias e sugestões presentes na imagem e nos textos aqui reunidos, redija uma dissertação argumentativa, em prosa, sobre o seguinte tema:

O altruísmo e o pensamento a longo prazo ainda têm lugar no mundo contemporâneo?

${ }^{*}$ Altruísmo $=$ s.m. Tendência ou inclinação de natureza instintiva que incita o ser humano à preocupação com o outro.

Dicionário Houaiss da língua portuguesa, 2009.

$\mathrm{Na}$ proposta de 2011, os textos I e II apresentam lugares e paisagens.

Focalizando a estabilidade de plantações e o fortalecimento das relações pela ação 
abnegada do indivíduo como contraponto para se discutir o altruísmo na contemporaneidade. A categoria de espaço é propícia para trabalhar com esta aparente inequação.

Intuímos que o índice de autoria do candidato possa ser verificado pelo nível de transposição textual que se restringe à proximidade da imagem do objeto, à explanação de percepção evidenciada por reproduzir cópia dos textos e, por fim, ao grau de abstratização representado pelo repertório cultural, diversificado e ligado ao texto. Voltaremos a essa discussão no capítulo IV, no qual procedemos à análise de dados.

Olhar para as instruções dos candidatos permite reforçar a interpretação apresentada anteriormente no que tange à condução de teses orientadas para o espaço. Para facilitar a visualização de elementos que conduzem a essa elaboração espacial, deixamos destacados itens dessa natureza:

\begin{tabular}{|c|l|}
\hline Ano & \multicolumn{1}{|c|}{ INSTRUÇÃO DA FUVEST PARA REDAÇÃO } \\
\hline 2004 & $\begin{array}{l}\text { Redija uma DISSERTAÇÃO EM PROSA, na qual você apontará, sucintamente, as diferentes } \\
\text { concepções do tempo, presentes nos três textos, e argumentará em favor da concepção do } \\
\text { tempo com a qual você mais se identifica. }\end{array}$ \\
\hline 2005 & $\begin{array}{l}\text { Como você pode verificar, observando o noticiário da imprensa e o texto da internet aqui } \\
\text { reproduzidos, a catraca que "apareceu" em uma praça de São Paulo era, na verdade, um } \\
\text { "Monumento à catraca invisível", ali instalado pelo grupo artístico "Contra Filé", como parte de } \\
\text { seu "Programa para a descatracalização da vida". Tudo indica, portanto, que o grupo } \\
\text { responsável por este programa acredita que há um excesso de controles, dos mais variados } \\
\text { tipos, que se exercem sobre os corpos e as mentes das pessoas, submetendo-as a constantes } \\
\text { limitações e constrangimentos. Tendo em vista as motivações do grupo, você julga que o } \\
\text { programa por ele desenvolvido se justifica? Considerando essa questão, além de outras que } \\
\text { você ache pertinentes, redija uma DISSERTAÇÃO EM PROSA, argumentando de modo a } \\
\text { apresentar seu ponto de vista sobre o assunto. }\end{array}$ \\
$\begin{array}{l}\text { Os três textos acima apresentam diferentes visões de trabalho. O primeiro procura conceituar } \\
\text { essa atividade e prever seu futuro. O segundo trata de suas condições no mundo } \\
\text { contemporâneo e o último, ilustrado pela famosa escultura de Michelangelo, refere-se ao trabalho } \\
\text { de artista. Relacione esses três textos e com base nas idéias neles contidas, além de outras que } \\
\text { julgue relevantes, redija uma DISSERTAÇÃO EM PROSA, argumentando sobre o que leu acima }\end{array}$ \\
\hline 2006
\end{tabular}




\begin{tabular}{|c|c|}
\hline & e também sobre os outros pontos que você tenha considerado pertinentes. \\
\hline 2007 & $\begin{array}{l}\text { A amizade tem sido objeto de reflexões e elogios de pensadores e artistas de todas as épocas. } \\
\text { Os trechos sobre esse tema, aqui reproduzidos, pertencem a um pensador da Antigüidade } \\
\text { Clássica (Cícero), a um pensador do século XVI (Montaigne) e a compositores da música } \\
\text { popular brasileira contemporânea. Você considera adequadas as idéias neles expressas? Elas } \\
\text { são atuais, isto é, você julga que elas têm validade no mundo de hoje? O que sua própria } \\
\text { experiência lhe diz sobre esse assunto? Tendo em conta tais questões, além de outras que você } \\
\text { julgue pertinentes, redija uma DISSERTAÇÃO EM PROSA, argumentando de modo a expor seu } \\
\text { ponto de vista sobre o assunto. }\end{array}$ \\
\hline 2008 & $\begin{array}{l}\text { Os textos apresentados trazem reflexões e notícias sobre o mundo digital. Com base nesses } \\
\text { textos e em outras informações e idéias que julgar pertinentes, redija uma DISSERTAÇÃO EM } \\
\text { PROSA, argumentando de modo claro e coerente. }\end{array}$ \\
\hline 2009 & $\begin{array}{l}\text { As fronteiras geográficas são passíveis de contínua mobilidade, dependendo dos } \\
\text { movimentos sociais e políticos de um ou mais grupos de pessoas. } \\
\text { Além do significado geográfico, físico, o termo "fronteira" é utilizado também em sentido figurado, } \\
\text { especialmente, quando se refere a diferentes campos do conhecimento. Assim, existem } \\
\text { fronteiras psicológicas, fronteiras do pensamento, da ciência, da linguagem etc. } \\
\text { Com base nas ideias sugeridas acima, escolha uma ou até duas delas, como tema, e redija uma } \\
\text { dissertação em prosa, utilizando informações e argumentos que deem consistência a seu ponto } \\
\text { de vista. } \\
\text { Procure seguir estas instruções: } \\
\text { - Lembre-se de que a situação de produção de seu texto requer o uso da modalidade escrita } \\
\text { culta da língua portuguesa. } \\
\text { - Dê um título para sua redação, que deverá ter entre } 20 \text { e } 30 \text { linhas. }\end{array}$ \\
\hline 2010 & $\begin{array}{l}\text { Na civilização em que se vive hoje, constroem-se imagens, as mais diversas, sobre os mais } \\
\text { variados aspectos; constroem-se imagens, por exemplo, sobre pessoas, fatos, livros, instituições } \\
\text { e situações. } \\
\text { No cotidiano, é comum substituir-se o real imediato por essas imagens. } \\
\text { Dentre as possibilidades de construção de imagens enumeradas acima, em negrito, escolha } \\
\text { apenas uma, como tema de seu texto, e redija uma dissertação em prosa, lançando mão de } \\
\text { argumentos e informações que deem consistência a seu ponto de vista. } \\
\text { Instruções: } \\
\text { - Lembre-se de que a situação de produção de seu texto requer o uso da modalidade escrita } \\
\text { culta da língua portuguesa. } \\
\text { Dê um título para sua redação, a qual deverá ter entre } 20 \text { e } 30 \text { linhas. } \\
\text { NÃO será aceita redação em forma de verso. }\end{array}$ \\
\hline 2011 & $\begin{array}{l}\text { Como mostram os textos } 1 \text { e } 2 \text {, a imagem de abnegação fornecida pela palma talipot, que, de } \\
\text { certo modo, "sacrifica" a própria vida para criar novas vidas, é reforçada pelo altruísmo* de } \\
\text { Roberto Burle Marx, que a plantou, não para seu próprio proveito, mas para o dos outros. Em } \\
\text { contraposição, o mundo atual teria escolhido o caminho oposto. } \\
\text { Com base nas ideias e sugestões presentes na imagem e nos textos aqui reunidos, redija uma } \\
\text { dissertação argumentativa, em prosa, sobre o seguinte tema: } \\
\text { O altruísmo e o pensamento a longo prazo ainda têm lugar no mundo contemporâneo? } \\
\text { *Altruísmo = s.m. Tendência ou inclinação de natureza instintiva que incita o ser humano à } \\
\text { preocupação com o outro. } \\
\text { Dicionário Houaiss da língua portuguesa, } 2009 \text {. } \\
\text { Instruções: } \\
\text { - Lembre-se de que a situação de produção de seu texto requer o uso da norma padrão da língua } \\
\text { portuguesa. } \\
\text { - A redação deverá ter entre } 20 \text { e } 30 \text { linhas. } \\
\text { - Dê um título a sua redação }\end{array}$ \\
\hline
\end{tabular}

Quadro 9: Resumo das Propostas FUVEST 
Poderemos acreditar que um ou outro tema favoreça a mobilização da categoria espaçotemporal, como argumentamos anteriormente. Essa é a razão pela qual procederemos a uma incursão nas 1.600 redações selecionadas para análise e verificaremos se, independentemente do tema, o candidato, no parágrafo introdutório, lança mão da marcação Espacial/Temporal. Também será relevante notar a gradação do índice de autoria, como já observamos também. Passemos, então, a tratar das amostras que compõem o corpus.

\section{$\checkmark$ O Corpus}

O corpus sob análise é composto de 1.600 redações dissertativoargumentativas produzidas pelos candidatos dos exames vestibulares da FUVEST, no período de 2004 a 2011, sendo distribuídas, a cada ano, 200 (duzentas) amostras. Como sistemática adotada para pesquisa na FUVEST uma equipe técnica categoriza essas redações em dois grandes blocos polarizados entre as "melhores" e as "piores" notas $^{32}$.

Dizem os funcionalistas que, obedecendo ao princípio da iconicidade, quanto mais importante ou mais complexa a informação elaborada, mais material linguístico deverá ser mobilizado para a sua codificação sintática. Se esse princípio for aplicado à extensão das redações, parece haver uma referendação do citado princípio: 19\% das

\footnotetext{
${ }^{32}$ Essa categorização feita pela Fuvest é somente para fins de pesquisa. É oportuno esclarecer que a instituição preserva a identificação dos candidatos e apenas publica, a título de exemplificação, as melhores.
} 
redações de piores notas tiveram extensão de 30 ou mais linhas, ao passo as redações de melhores notas tiveram essa mesma extensão em $94 \%$ dos casos.

Esse resultado pode também conduzir-nos a uma outra questão: seriam as redações de maior extensão aquelas que apresentam maior indício de autoria? Mobilizaremos esforços para alcançarmos resposta para esta questão.

\subsection{Problemas sobre a delimitação do objeto}

Após recolher as redações e delas selecionar para análise somente o parágrafo introdutório, notamos que as expressões "atualmente", "nos dias de hoje”, "hoje em dia", "no mundo atual", "vivemos hoje em um mundo", "em nossa sociedadde atual", "no mundo contemporâneo", "um dia desses", "quando", "em uma sociedade”, "a sociedade contemporânea", "no Brasil atualmente", "atualmente no Brasil" eram recorrentes.

Inicialmente, supusemos que a classe adverbial fosse uma necessidade geral para a elaboração introdutória. Posteriormente, analisando de um modo mais detido esses dados, apoiados em postulados teóricos dos estudos sobre gramaticalização, direcionamos o olhar para as categorias cognitivas. Chegamos àa conclusão, então, que a categoria de tempo era muito recorrente, mas sozinha não dava conta dos padrões introdutórias com que nos deparamos. Havia uma gama de dados que topicalizava expressões que representavam a categoria de lugar.

Algumas idiossincrasias se manifestavam na classificação interpretativa de expressões que, com certa importância frequencial, acumulavam classificação de 
tempo e de lugar. Em consonância com nossas reflexões apresentadas no capítulo I, em que tratamos do continuum: pessoa $>$ objeto $>$ espaço $>$ tempo $>$ qualidade, passamos a questionar o estatuto da categoria espaço e chegamos à conclusão de que espaço é uma categoria mais abstrata do que lugar porque incorpora tempo. Portanto, espaço corresponde neste trabalho à complexidade existente numa cena que compreende pessoa, objeto, lugar e tempo. Ainda uma segunda conclusão foi que a maioria das expressões introdutórias correspondiam, na verdade, à categoria de espaço.

Mas as descoberta não pararam por aí. Dialogando com as teorias cognitivas, descobrimos que o espaço é fundamental para a construção da subjetividade. Foi então que nos perguntamos o porquê de a maioria dos candidatos recorrerem a uma localização de lugar-tempo-espaço para a primeira expressão no texto dissertativoargumentativo. A resposta veio dos neurocientistas, que argumentam sobre o desenvolvimento filogênico baseado na teoria do espaço, o que ganhou eco na linguística dos espaços mentais.

Durante as entrevistas, anacrônicas em relação ao momento de análise dos dados, percebemos que essa alta recorrência poderia ser uma resposta ao treino escolar para a escrita. Tivemos acesso, então, a um texto didático que explicitava dezoito formas de se iniciar um texto dissertativo:

O PARÁGRAFO-CHAVE: 18 FORMAS PARA VOCÊ COMEÇAR UM TEXTO

Ao escrever seu primeiro parágrafo, você pode fazê-lo de forma criativa. Ele deve atrair a atenção do leitor. Por isso, evite os lugarescomuns como: atualmente, hoje em dia, desde épocas remotas, o mundo 
de hoje, a cada dia que passa, no mundo em que vivemos, na atualidade.

Listamos aqui dezoito formas de começar um texto. Elas vão das mais simples às mais complexas.

1. Uma declaração (tema: liberação da maconha)

É um grave erro a liberação da maconha. Provocará de imediato violenta elevação do consumo. O Estado perderá o precário controle que ainda exerce sobre as drogas psicotrópicas e nossas instituições de recuperação de viciados não terão estrutura suficiente para atender à demanda.

Alberto Corazza, Isto\& 20 dez. 1995.

A declaração é a forma mais comum de começar um texto. Procure fazer uma declaração forte, capaz de surpreender o leitor.

2. Definição (tema: o mito)

O mito, entre os povos primitivos, é uma forma de se situar no mundo, isto é, de encontrar o seu lugar entre os demais seres da natureza. É um modo ingênuo, fantasioso, anterior a toda reflexão e não-crítico de estabelecer algumas verdades que não só explicam parte dos fenômenos naturais ou mesmo a construção cultural, mas que dão, também, as formas da ação humana.

ARANHA, Maria Lúcia de Arruda \& MARTINS, Maria Helena Pires. Temas de Filosofia. São Paulo, Moderna, 1992. p. 62.

A definição é uma forma simples e muito usada em parágrafos-chave, sobretudo em textos dissertativos. Pode ocupar só a primeira frase ou todo o primeiro parágrafo.

3. Divisão (tema: exclusão social)

Predominam ainda no Brasil duas conviç̧ões errôneas sobre o problema da exclusão social: a de que ela deve ser enfrentada apenas pelo poder público e a de que sua superação envolve muitos recursos e esforços extraordinários. Experiências relatadas nesta Folha mostram que o combate à marginalidade social em Nova York vem contando com intensivos esforços do poder público e ampla participação da iniciativa privada.

Folha de S.Paulo, 17 dez. 1996.

Ao dizer que há duas convicções errôneas, fica logo clara a direção que o parágrafo vai tomar. $\mathrm{O}$ autor terá de explicitá-las na frase seguinte.

4. Oposição (tema: a educação no Brasil)

De um lado, professores mal pagos, desestimulados, esquecidos pelo governo. De outro, gastos excessivos com computadores, antenas parabólicas, aparelhos de videocassete. É este o paradoxo que vive hoje a educação no Brasil.

As duas primeiras frases criam uma oposicão (de um lado/de outro) que estabelecerá o rumo da argumentação.

Também se pode criar uma oposição dentro da frase, como neste 
exemplo:

Vários motivos me levaram a este livro. Dois se destacam pelo grau de envolvimento: raiva e esperança. Explico-me: raiva por ver o quanto a cultura ainda é vista como artigo supérfluo em nossa terra; esperança por observar quantos movimentos culturais têm acontecido em nossa história, e quase sempre como forma de resistência e/ou transformação. (...)

FEIJõ, Martin César. O queépolítica culturaL São Paulo, Brasiliense, 1985. p. 7.

O autor estabelece a oposição e logo depois explica os termos que a compõem.

5. Alusão histórica (tema: globalização)

Após a queda do Muro de Berlim, acabaram-se os antagonismos lesteoeste e o mundo parece ter aberto de vez as portas para a globalização. As fronteiras foram derrubadas e a economia entrou em rota acelerada de competição.

O leitor é situado no tempo e pode ter uma melhor dimensão do problema.

6. Uma pergunta (tema: a saúde no Brasil)

Será que é com novos impostos que a saúde melhorará no Brasil? Os contribuintes já estão cansados de tirar dinheiro do bolso para tapar um buraco que parece não ter fim. A cada ano, somos lesados por novos impostos para alimentar um sistema que só parece piorar.

A pergunta não é respondida de imediato. Ela serve para despertar a atenção do leitor para 0 tema e será respondida ao longo da argumentação.

7. Uma frase nominal seguida de explicação (tema: a educação no Brasil)

Uma tragédia. Essa é a conclusão da própria Secretaria de Avaliação e Informação Educacional do Ministério da Educação e Cultura sobre o desempenho dos alunos do 30 ano do 2 grau submetidos ao Saeb (Sistema de Avaliação da Educação Básica), que ainda avaliou estudantes da 4 série e da 8 série do 1 grau em todas as regiões do território nacional.

Folha deS.Paulo, 27 nov. 1996.

A palavra tragédia é explicada logo depois, retomada por essa é a conclusão.

8. Adjetivação (tema: a educação no Brasil)

Equivocada e pouco racional. Esta é a verdadeira adjetivação para a política educacional do governo.

Anderson Sanches, Iníocus, n. 5, ano 1, out. 1966. p. 2.

A adjetivação inicial será a base para desenvolver o tema. O autor dirá, nos parágrafos seguintes, por que acha a política educacional do governo equivocada e pouco racional.

9. Citação (tema: política demográfica)

"As pessoas chegam ao ponto de uma criança morrer e os pais não chorarem mais, trazerem a criança, jogarem num bolo de mortos, virarem as costas e irem embora." O comentário, do fotógrafo Sebastião Salgado, 
falando sobre o que viu em Ruanda, é um acicate no estado de letargia ética que domina algumas nações do Primeiro Mundo.

DI FRANCO, Carlos Alberto. Jornalismo, ética e qualidade. Rio de Janeiro, Vozes, 1995. P. 173

A citação inicial facilita a continuidade do texto, pois ela é retomada pela palavra comentário da segunda frase.

10. Citação de forma indireta (tema: consumismo)

Para Marx a religião é o ópio do povo. Raymond Aron deu o troco: o marxismo é o ópio dos intelectuais. Mas nos Estados Unidos o ópio do povo é mesmo ir às compras. Como as modas americanas são contagiosas, é bom ver de que se trata.

Cláudio de Moura e Castro, Veja, 13 nov. 1996.

Esse recurso deve ser usado quando não sabemos textualmente a citação. É melhor citar de forma indireta que de forma errada.

11. Exposição de ponto de vista oposto (tema: o provão)

O ministro da Educação se esforça para convencer de que o provão é fundamental para a melhoria da qualidade do ensino superior. Para isso, vem ocupando generosos espaços na mídia e fazendo milionária campanha publicitária, ensinando como gastar mal o dinheiro que deveria ser investido na educação.

Orlando Silva Júnior e Eder Roberto Silva, Folha de $£$ Paulo, 5 nov. 1996.

Ao começar o texto com a opinião contrária, delineia-se, de imediato, qual a posicão dos autores. Seu objetivo será refutar os argumentos do opositor, numa espécie de contra-argumentação.

12. Comparação (tema: reforma agrária)

O tema da reforma agrária está presente há bastante tempo nas discussões sobre os problemas mais graves que afetam o Brasil. Numa comparação entre o movimento pela abolição da escravidão no Brasil, no final do século passado e, atualmente, o movimento pela reforma agrária, podemos perceber algumas semelhanças. Como na época da abolição da escravidão existiam elementos favoráveis e contrários a ela, também hoje há os que são a favor e os que são contra a implantação da reforma agrária no Brasil.

OLIVEIRA, Pérsio Santos de. Introdução à sociologia. São Paulo, Ática, 1991. p. 101.

Para introduzir o tema da reforma agrária, o autor comparou a sociedade de hoje com a do final do século XIX, mostrando a semelhança de comportamento entre elas.

13. Retomada de um provérbio (tema: mídia e tecnologia)

O corriqueiro adágio de que o pior cego é o que não quer ver se aplica com perfeição na análise sobre 0 atual estágio da mídia: desconhecer ou tentar ignorar os incríveis avanços tecnológicos de nossos dias, e supor que eles não terão reflexos profundos no futuro dos jornais é simplesmente impossível.

Jayme Sirotsky, Folha de 5. Paulo, 5 dez. 1995. 
Sempre que você usar esse recurso, não escreva o provérbio simplesmente. Faça um comentário sobre ele para quebrar a idéia de lugar-comum que todos eles trazem. No exemplo acima, o autor diz "o corriqueiro adágio" e assim demonstra que está consciente de que está partindo de algo por demais conhecido.

14. Ilustração (tema: aborto)

O Jornal do Comércio, de Manaus, publicou um anúncio em que uma jovem de dezoito anos, já mãe de duas filhas, dizia estar grávida mas não queria a criança. Ela a entregaria a quem se dispusesse a pagar sua ligação de trompas. Preferia dar o filho a ter que fazer um aborto.

O tema é tabu no Brasil. (...)

Antonio Carlos Viana, O Quê, edição de 16 a 22 jul. 1994.

Você pode começar narrando um fato para ilustrar o tema. Veja que a coesão do parágrafo seguinte se faz de forma fácil: a palavra tema retoma a questão que vai ser discutida.

15. Uma seqüência de frases nominais (frases sem verbo) (tema: a impunidade no Brasil)

Desabamento de shopping em Osasco. Morte de velhinhos numa clínica do Rio. Meia centena de mortes numa clínica de hemodiálise em Caruaru. Chacina de sem-terra em Eldorado dos Carajás.

Muitos meses já se passaram e esses fatos continuam impunes.

O que se deve observar nesse tipo de introdução são os paralelismos que dão equilíbrio às diversas frases nominais. A estrutura de cada frase deve ser semelhante.

16. Alusão a um romance, um conto, um poema, um filme (tema: a intolerância religiosa)

Quem assistiu ao filme $A$ rainha Margot, com a deslumbrante Isabelle Adjani, ainda deve ter os fatos vivos na memória. Na madrugada de 24 de agosto de 1572, as tropas do rei de França, sob ordens de Catarina de Médicis, a rainha-mãe e verdadeira governante, desencadearam uma das mais tenebrosas carnificinas da História. (...)

Desse horror a História do Brasil está praticamente livre. (...) Veja, 25 out. 1995.

O resumo do filme $A$ rainha Margot serve de introdução para desenvolver o tema da intolerância religiosa. A coesão com o segundo parágrafo dá-se através da palavra horror, que sintetiza o enredo do filme contado no parágrafo inicial.

17. Descrição de um fato de forma cinematográfica (tema: violência urbana)

Madrugada de 11 de agosto. Moema, bairro paulistano de classe média. Choperia Bodega - um bar da moda, freqüentado por jovens bemnascidos.

Um assalto. Cinco ladrões. Todos truculentos. Duas pessoas mortas: Adriana Ciola, 23, e José Renato Tahan, 25. Ela, estudante. Ele, dentista. Josias de Souza, Folha de S.Paulo, 30 set. 1996.

O parágrafo é desenvolvido por flashes, o que dá agilidade ao texto e 
prende a atenção do leitor. Depois desses dois parágrafos, o autor fala da origem do movimento "Reage São Paulo".

18. Omissão de dados identificadores (tema: ética)

Mas o que significa, afinal, esta palavra, que virou bandeira da juventude? Com certeza não é algo que se refira somente à política ou às grandes decisões do Brasil e do mundo. Segundo Tarcísio Padilha, ética é um estudo filosófico da ação e da conduta humanas cujos valores provém da própria natureza do homem e se adaptam às mudanças da história e da sociedade.

O Globo, 13 set. 1992.

As duas primeiras frases criam no leitor certa expectativa em relação ao tema que se mantém em suspenso até a terceira frase. Pode-se também construir todo o primeiro parágrafo omitindo o tema, esclarecendoo apenas no parágrafo seguinte.

Nessa publicação, da Editora Scipione, denominada Roteiro de redação - lendo e argumentando, coordenada por Antonio Carlos Viana (1998), é possível verificar que a primeira informação orienta o autor de um texto a elaborar uma introdução criativa, de modo que atraia a atenção do leitor. Em seguida, sem apresentar o porquê, a orientação é sobre aquilo que se deve evitar: os lugares-comuns, como "atualmente", "hoje em dia", "desde épocas remotas", "o mundo de hoje", "a cada dia que passa", "no mundo em que vivemos", "na atualidade". No passo posterior, enfim, apresentam-se as 18 formas de iniciar o texto, conforme resumiremos no quadro a seguir:

\begin{tabular}{|c|c|c|}
\hline Tipo & Exemplo & Explicação \\
\hline 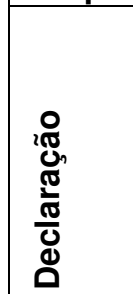 & $\begin{array}{l}\text { É um grave erro a liberação da maconha. Provocará de } \\
\text { imediato violenta elevação do consumo. O Estado } \\
\text { perderá o precário controle que ainda exerce sobre as } \\
\text { drogas psicotrópicas e nossas instituições de } \\
\text { recuperação de viciados não terão estrutura suficiente } \\
\text { para atender à demanda. }\end{array}$ & $\begin{array}{l}\text { A declaração é a forma mais } \\
\text { comum de começar um texto. } \\
\text { Procure fazer uma declaração } \\
\text { forte, capaz de surpreender o } \\
\text { leitor }\end{array}$ \\
\hline
\end{tabular}




\begin{tabular}{|c|c|c|}
\hline : & $\begin{array}{l}\text { O mito, entre os povos primitivos, é uma forma de se } \\
\text { situar no mundo, isto é, de encontrar o seu lugar entre os } \\
\text { demais seres da natureza. É um modo ingênuo, fantasioso, } \\
\text { anterior a toda reflexão e não-crítico de estabelecer } \\
\text { algumas verdades que não só explicam parte dos fenôme- } \\
\text { nos naturais ou mesmo a construção cultural, mas que dão, } \\
\text { também, as formas da ação humana. }\end{array}$ & $\begin{array}{l}\text { A definição é uma forma } \\
\text { simples e muito usada em } \\
\text { parágrafos-chave, sobretudo } \\
\text { em textos dissertativos. Pode } \\
\text { ocupar só a primeira frase ou } \\
\text { todo o primeiro parágrafo. }\end{array}$ \\
\hline 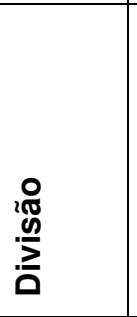 & $\begin{array}{l}\text { Predominam ainda no Brasil duas convicções errôneas } \\
\text { sobre o problema da exclusão social: a de que ela deve ser } \\
\text { enfrentada apenas pelo poder público e a de que sua } \\
\text { superação envolve muitos recursos e esforços } \\
\text { extraordinários. Experiências relatadas nesta Folha mos- } \\
\text { tram que o combate à marginalidade social em Nova York } \\
\text { vem contando com intensivos esforços do poder público e } \\
\text { ampla participação da iniciativa privada. }\end{array}$ & $\begin{array}{l}\text { Ao dizer que há duas } \\
\text { convicções errôneas, fica logo } \\
\text { clara a direção que o parágrafo } \\
\text { vai tomar. O autor terá de } \\
\text { explicitá-las na frase seguinte. }\end{array}$ \\
\hline 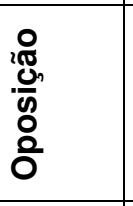 & $\begin{array}{l}\text { De um lado, professores mal pagos, desestimulados, } \\
\text { esquecidos pelo governo. De outro, gastos excessivos } \\
\text { com computadores, antenas parabólicas, aparelhos de } \\
\text { videocassete. É este o paradoxo que vive hoje a } \\
\text { educação no Brasil. }\end{array}$ & $\begin{array}{l}\text { As duas primeiras frases criam } \\
\text { uma oposicão (de um lado/de } \\
\text { outro) que estabelecerá o rumo } \\
\text { da argumentação. }\end{array}$ \\
\hline 禺 & $\begin{array}{l}\text { Após a queda do Muro de Berlim, acabaram-se os } \\
\text { antagonismos leste-oeste e o mundo parece ter aberto de } \\
\text { vez as portas para a globalização. As fronteiras foram } \\
\text { derrubadas e a economia entrou em rota acelerada de } \\
\text { competição. }\end{array}$ & $\begin{array}{l}\text { O leitor é situado no tempo e } \\
\text { pode ter uma melhor dimensão } \\
\text { do problema. }\end{array}$ \\
\hline 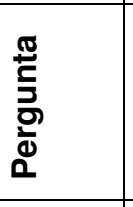 & $\begin{array}{l}\text { Será que é com novos impostos que a saúde melhorará } \\
\text { no Brasil? Os contribuintes já estão cansados de tirar } \\
\text { dinheiro do bolso para tapar um buraco que parece não ter } \\
\text { fim. A cada ano, somos lesados por novos impostos para } \\
\text { alimentar um sistema que só parece piorar. }\end{array}$ & $\begin{array}{l}\text { A pergunta não é respondida de } \\
\text { imediato. Ela serve para } \\
\text { despertar a atenção do leitor } \\
\text { para o tema e será respondida } \\
\text { ao longo da argumentação. }\end{array}$ \\
\hline 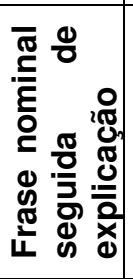 & $\begin{array}{l}\text { Uma tragédia. Essa é a conclusão da própria Secretaria } \\
\text { de Avaliação e Informação Educacional do Ministério da } \\
\text { Educação e Cultura sobre o desempenho dos alunos do } 30 \\
\text { ano do } 2 \sim \text { grau submetidos ao Saeb (Sistema de Avaliação } \\
\text { da Educação Básica), que ainda avaliou estudantes da } 4 \sim \\
\text { série e da } 8 \sim \text { série do } 1 \sim \text { grau em todas as regiões do } \\
\text { território nacional. }\end{array}$ & $\begin{array}{l}\text { A palavra tragédia é explicada } \\
\text { logo depois, retomada por essa } \\
\text { é a conclusão. }\end{array}$ \\
\hline 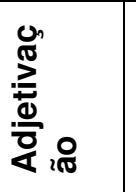 & $\begin{array}{l}\text { A adjetivação inicial será a base para desenvolver o } \\
\text { tema. O autor dirá, nos parágrafos seguintes, por que acha } \\
\text { a política educacional do governo equivocada e pouco } \\
\text { racional. }\end{array}$ & $\begin{array}{l}\text { Equivocada e pouco racional. } \\
\text { Esta é a verdadeira adjetivação } \\
\text { para a política educacional do } \\
\text { governo. }\end{array}$ \\
\hline 迅 & $\begin{array}{l}\text { "As pessoas chegam ao ponto de uma criança morrer e } \\
\text { os pais não chorarem mais, trazerem a criança, jogarem } \\
\text { num bolo de mortos, virarem as costas e irem embora." O } \\
\text { comentário, do fotógrafo Sebastião Salgado, falando sobre } \\
\text { o que viu em Ruanda, é um acicate no estado de letargia } \\
\text { ética que domina algumas nações do Primeiro Mundo. }\end{array}$ & $\begin{array}{l}\text { A citação inicial facilita a } \\
\text { continuidade do texto, pois ela é } \\
\text { retomada pela palavra } \\
\text { comentário da segunda frase. }\end{array}$ \\
\hline 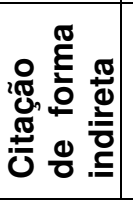 & $\begin{array}{l}\text { Para Marx a religião é o ópio do povo. Raymond Aron } \\
\text { deu o troco: o marxismo é o ópio dos intelectuais. Mas nos } \\
\text { Estados Unidos o ópio do povo é mesmo ir às compras. } \\
\text { Como as modas americanas são contagiosas, é bom ver de } \\
\text { que se trata. }\end{array}$ & $\begin{array}{l}\text { Esse recurso deve ser usado } \\
\text { quando não sabemos } \\
\text { textualmente a citação. É me- } \\
\text { Ihor citar de forma indireta que } \\
\text { de forma errada. }\end{array}$ \\
\hline
\end{tabular}




\begin{tabular}{|c|c|c|}
\hline 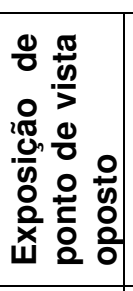 & $\begin{array}{l}\text { O ministro da Educação se esforça para convencer de } \\
\text { que o provão é fundamental para a melhoria da qualidade } \\
\text { do ensino superior. Para isso, vem ocupando generosos } \\
\text { espaços na mídia e fazendo milionária campanha } \\
\text { publicitária, ensinando como gastar mal o dinheiro que } \\
\text { deveria ser investido na educação. }\end{array}$ & $\begin{array}{l}\text { Ao começar o texto com a } \\
\text { opinião contrária, delineia-se, } \\
\text { de imediato, qual a posicão dos } \\
\text { autores. Seu objetivo será } \\
\text { refutar os argumentos do } \\
\text { opositor, numa espécie de } \\
\text { contra-argumentação. }\end{array}$ \\
\hline & $\begin{array}{l}\text { O tema da reforma agrária está presente há bastante } \\
\text { tempo nas discussões sobre os problemas mais graves que } \\
\text { afetam o Brasil. Numa comparação entre o movimento pela } \\
\text { abolição da escravidão no Brasil, no final do século } \\
\text { passado e, atualmente, o movimento pela reforma agrária, } \\
\text { podemos perceber algumas semelhanças. Como na época } \\
\text { da abolição da escravidão existiam elementos favoráveis } \\
\text { e contráios a ela, também hoje há os que são a favor e os } \\
\text { que são contra a implantação da reforma agrária no Brasil. }\end{array}$ & $\begin{array}{l}\text { Para introduzir o tema da } \\
\text { reforma agrária, o autor } \\
\text { comparou a sociedade de hoje } \\
\text { com a do final do século XIX, } \\
\text { mostrando a semelhança de } \\
\text { comportamento entre elas. }\end{array}$ \\
\hline 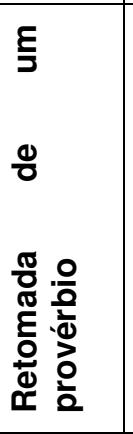 & $\begin{array}{l}\text { O corriqueiro adágio de que o pior cego é o que não } \\
\text { quer ver se aplica com perfeição na análise sobre o atual } \\
\text { estágio da mídia: desconhecer ou tentar ignorar os } \\
\text { incríveis avanços tecnológicos de nossos dias, e supor que } \\
\text { eles não terão reflexos profundos no futuro dos jornais é } \\
\text { simplesmente impossível. }\end{array}$ & $\begin{array}{l}\text { Sempre que você usar esse } \\
\text { recurso, não escreva } \\
\text { provérbio simplesmente. Faça } \\
\text { um comentário sobre ele para } \\
\text { quebrar a idéia de lugar-comum } \\
\text { que todos eles trazem. No } \\
\text { exemplo acima, o autor diz "o } \\
\text { corriqueiro adágio" e assim } \\
\text { demonstra que está consciente } \\
\text { de que está partindo de algo } \\
\text { por demais conhecido. }\end{array}$ \\
\hline & $\begin{array}{l}\text { OJornal do Comércio, de Manaus, publicou um anúncio } \\
\text { em que uma jovem de dezoito anos, já mãe de duas } \\
\text { filhas, dizia estar grávida mas não queria a criança. Ela } \\
\text { a entregaria a quem se dispusesse a pagar sua ligação } \\
\text { de trompas. Preferia dar o filho a ter que fazer um } \\
\text { aborto. } \\
\text { Otema é tabu no Brasil. (...) }\end{array}$ & $\begin{array}{l}\text { Você pode começar narrando } \\
\text { um fato para ilustrar o tema. } \\
\text { Veja que a coesão do parágrafo } \\
\text { seguinte se faz de forma fácil: a } \\
\text { palavra tema retoma a questão } \\
\text { que vai ser discutida. }\end{array}$ \\
\hline 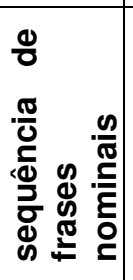 & $\begin{array}{l}\text { Desabamento de shopping em Osasco. Morte de } \\
\text { velhinhos numa clínica do Rio. Meia centena de } \\
\text { mortes numa clínica de hemodiálise em Caruaru. } \\
\text { Chacina de sem-terra em Eldorado dos Carajás. } \\
\text { Muitos meses já se passaram e esses fatos continuam } \\
\text { impunes. }\end{array}$ & $\begin{array}{l}\text { O que se deve observar nesse } \\
\text { tipo de introdução são os } \\
\text { paralelismos que dão equilíbrio } \\
\text { às diversas frases nominais. A } \\
\text { estrutura de cada frase deve } \\
\text { ser semelhante. }\end{array}$ \\
\hline 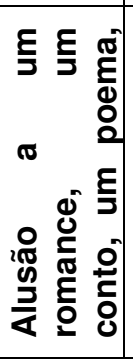 & $\begin{array}{l}\text { Quem assistiu ao filme } A \text { rainha Margot, com a } \\
\text { deslumbrante Isabelle Adjani, ainda deve ter os fatos } \\
\text { vivos na memória. Na madrugada de } 24 \text { de agosto de } \\
\text { 1572, as tropas do rei de França, sob ordens de } \\
\text { Catarina de Médicis, a rainha-mãe e verdadeira } \\
\text { governante, desencadearam uma das mais tenebrosas } \\
\text { carnificinas da História. (...) } \\
\text { Desse horror a História do Brasil está praticamente } \\
\text { livre. }\end{array}$ & $\begin{array}{l}\text { O resumo do filme A rainha } \\
\text { Margot serve de introdução } \\
\text { para desenvolver o tema da } \\
\text { intolerância religiosa. A coesão } \\
\text { com o segundo parágrafo dá-se } \\
\text { através da palavra horror, que } \\
\text { sintetiza o enredo do filme } \\
\text { contado no parágrafo inicial. }\end{array}$ \\
\hline
\end{tabular}




\begin{tabular}{|c|c|c|}
\hline 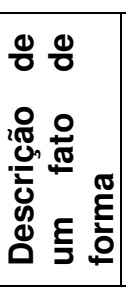 & $\begin{array}{l}\text { Madrugada de } \mathbf{1 1} \text { de agosto. Moema, bairro } \\
\text { paulistano de classe média. Choperia Bodega - um } \\
\text { bar da moda, freqüentado por jovens bem-nascidos. } \\
\text { Um assalto. Cinco ladrões. Todos truculentos. Duas } \\
\text { pessoas mortas: Adriana Ciola, 23, e José Renato } \\
\text { Tahan, 25. Ela, estudante. Ele, dentista. }\end{array}$ & $\begin{array}{l}\text { O parágrafo é desenvolvido por } \\
\text { flashes, o que dá agilidade ao } \\
\text { texto e prende a atenção do } \\
\text { leitor. Depois desses dois } \\
\text { parágrafos, o autor fala da } \\
\text { origem do movimento "Reage } \\
\text { São Paulo" }\end{array}$ \\
\hline 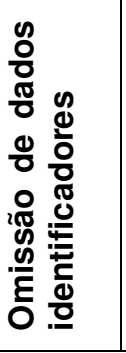 & $\begin{array}{l}\text { Mas o que significa, afinal, esta palavra, que virou } \\
\text { bandeira da juventude? Com certeza não é algo que se } \\
\text { refira somente à política ou às grandes decisões do } \\
\text { Brasil e do mundo. Segundo Tarcísio Padilha, ética é } \\
\text { um estudo filosófico da ação e da conduta humanas } \\
\text { cujos valores provém da própria natureza do homem e } \\
\text { se adaptam às mudanças da história e da sociedade. }\end{array}$ & $\begin{array}{l}\text { As duas primeiras frases criam } \\
\text { no leitor certa expectativa em } \\
\text { relação ao tema que se mantém } \\
\text { em suspenso até a terceira } \\
\text { frase. Pode-se também } \\
\text { construir todo o primeiro } \\
\text { parágrafo omitindo o tema, } \\
\text { esclarecendo-o apenas no } \\
\text { parágrafo seguinte. }\end{array}$ \\
\hline
\end{tabular}

Quadro 10: Resumo das 18 formas de iniciar o texto

Algumas considerações precisam ser feitas com relação a essas orientações. A primeira delas é que nos parecem pouco voltadas para o primeiro parágrafo, já que essas explicações também podem ser aplicadas aos demais parágrados da dissertação. Uma segunda diz respeito ao seu alto grau de subjetividade, o que propicia que em pouco ou nada ajuda ao aluno. Essas formas de iniciar um texto, mais se restringem a exemplos do que propriamente a explicações. Aliás, a abrangência da explicação não alcança outros casos, o que nos permite afirmar que algumas delas não seriam possíveis, se não fossem a presença dos exemplos.

Não devemos perder de vista que não se trata de buscar uma forma ideal de se iniciar um texto, mas, sim, de evidenciar as variadas "formas" que se dispõem a dar corpo ao que antecede a produção textual: o processamento cognitivo. E já sabemos que ele envolve vários fatores mentais como o protosself (condição básica ao indivíduo), self central (todo o conhecimento adquirido) e self autobiográfico (a forma de 
externalizar o conhecimento adquirido em texto escrito). Todos esses selves trabalham juntos para a (inter)subjetividade materializada via categorias cognitivas.

Uma outra observação cabe neste momento. Apesar de praticamente em todos os exemplos haver expressões de tempo e de lugar, nem todas são de fato estratégias para se iniciar um texto dissertativo. Consideramos as estratégias produtivas aquelas que aparecem em sua forma topicalizada e que podem, na verdade, carrear em termos de gradação a categoria de espaço. Essa gradação corresponde à forma como o candidato torna proveitosa a relação entre começar uma dissertação e criar um espaço conjunto de atenção.

Após analisarmos essas construções, priorizamos uma análise verticalizada das construções topicalizadas. A explicação é uma só: se o escrevente topicalizou, ele gramaticalizou sua intenção de priorizar o espaço em que esse diálogo se construiria. Esses e outros insights nos conduziram à análise de princípios funcionalistas, tais como o princípio de iconicidade, definido no capítulo I desta tese.

\subsection{Estratégias de referendação}

Uma vez que a categoria de tempo se mostrava muito recorrente, inclusive sobre os diferentes contextos e metáforas, como vimos no capítulo II, decidimos, em uma experiência docente, pesquisar qual sentido os alunos atribuiriam aos termos: passado, presente e futuro. A finalidade era verificar, naquele grupo de cerca de 40 
alunos de primeiro semestre de graduação de uma instituição particular, qual o campo semântico que poderíamos construir a partir das palavras apresentadas pelos discentes em relação ao tempo.

Hipotetizávamos que tais respostas dos alunos pudessem abordar as expressões que eram presentes na elaboração de uma tese. Como estratégia, propusemos a temática a respeito da administração do tempo, dessa forma induzindo o candidato a elaborar uma tese com a categoria de tempo. Observamos que, na referência ao tempo presente, menos itens se apresentaram, comparado-se ao passado e ao futuro. Com relação ao passado, verificamos, uma intersecção com o presente pela mobilização da palavra certeza, que se repetiu nos dois organogramas. Já o futuro destacou-se com maior número de expressões ligadas ao seu campo semântico, o que permite acreditar que o ser humano é muito mais motivado pelo futuro do que necessariamente pelas outras categorias temporais.

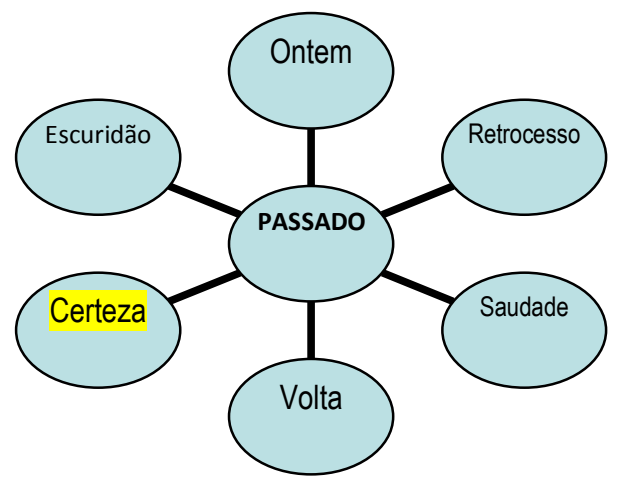

Organograma 1: Campo Semântico do termo Passado 


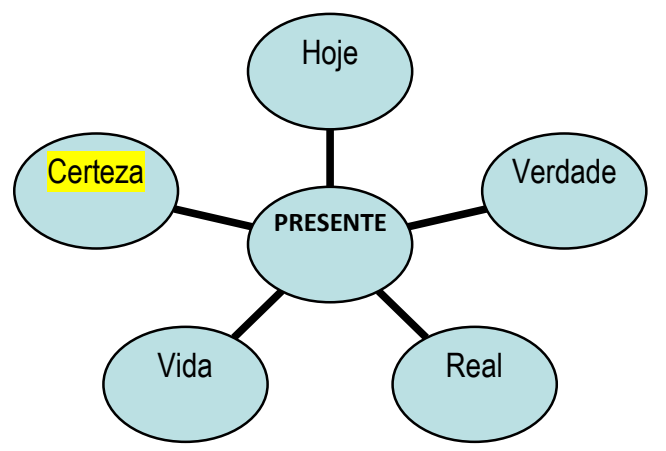

Organograma 2: Campo Semântico do termo Presente

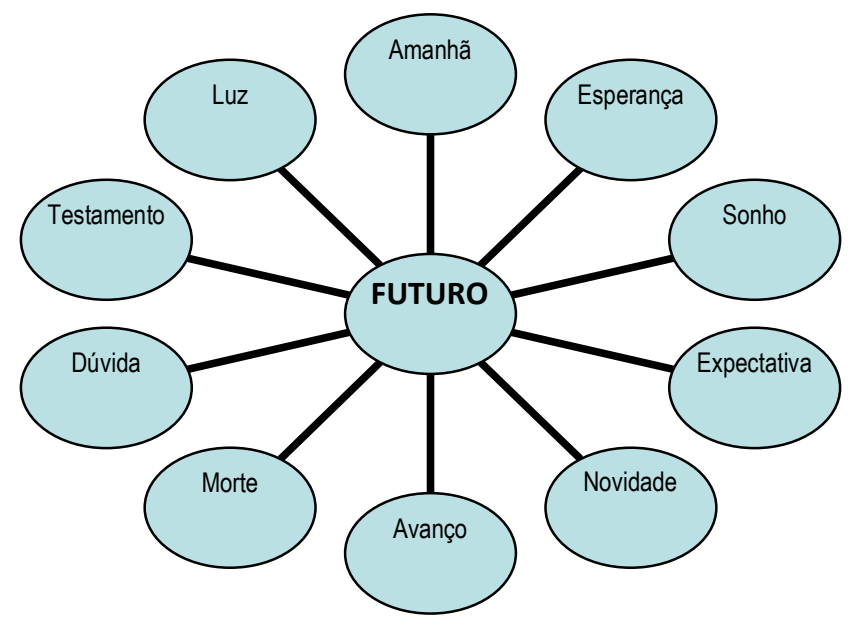

Organograma 3: Campo Semântico do termo Futuro

Dado que muito do que trazem esses alunos pré-vestibulandos pode ser lido em termos de construções derivadas de exemplos de professores em sala de aula, concebemos como relevante ouvir o depoimento de professores da rede pública e particular. Nessa consulta, pretendíamos discutir alguns quesitos relativos à elaboração 
da dissertação escolar. Para isso realizamos uma pesquisa de campo, por meio da qual elaboramos duas perguntas sobre as propriedades de uma "introdução". Responderam às questões 30 professores, sendo metade da rede pública e a outra metade da rede particular. No capítulo IV, desta tese, trataremos desses resultados e das possíveis implicações para as conclusões a que chegamos durante a análise das redações.

Outra estratégia de checagem de intuições de resultados com relação à interferência didática nas decisões introdutórias dos candidatos foi a consulta a 3 livros didáticos (Maia, 2009; Cereja \& Cochar, 2009; e Infante, 2009). O critério para a seleção desses livros foi a avaliação do Programa Nacional do Livro Didático do Ensino Médio (PNLEM), que atribui crédito de qualidade à publicação e, em consequência, alavanca sua distribuição pelas escolas do Ensino Médio. Saber em que medida as orientações didáticas conduzem a uma resposta introdutória eficiente e coincidente é o que nos orienta a tomar a decisão da consulta.

Supondo que os livros didáticos nada tragam de orientação para a construção do primeiro parágrafo, ainda assim nos restará a estratégia de visitar gramáticas normativas. Intuímos que esse seja o lugar preferencial de consulta de professores de português.

Cumprida a exposição do planejamento metodológico da pesquisa, passemos ao estudo avaliativo dos dados, cujos resultados nos conduzirão à compreensão das razões para que candidatos da FUVEST sintaticizem suas intenções discursivo- 
pragmáticas em termos de gramática e de construção do espaço seguro para a atenção conjunta. 


\section{CAPÍTULO IV}

\section{Estudo descritivo dos dados}

"Só um sentido de invenção e uma necessidade intensa de criar levam o homem a revoltar-se, a descobrir e a descobrir-se com lucidez." (Pablo Picasso)

Nesta seção, procederemos à análise dos dados numa perspectiva holística, que prevê a verificação do porquê de o candidato considerar o início do texto a parte mais difícil da dissertação. É interesse nesta tese saber até que ponto os candidatos estabelecem um diálogo com os excertos motivadores do tema e com os conhecimentos (extra)linguísticos derivados de suas vivências. A análise permitirá evidenciar, ainda, as estratégias adotadas para a construção do espaço de (inter)subjetividade, a fim de saber em que medida os princípios funcionalistas se aplicam.

\subsection{Uma abordagem holística dos dados}

Como expusemos anteriormente, no capítulo teórico, língua e linguagem ${ }^{33}$ são interesses centrais para muitos pesquisadores que não somente os linguistas. Do

\footnotetext{
${ }^{33} \mathrm{Em}$ tese não é possível segmentar os conceitos de língua e de linguagem numa abordagem holística. No entanto, quisemos enfatizar que consideramos tanto o sistema linguístico quanto as informações que contextualizam o uso, daí referirmos à linguagem.
} 
lugar em que nos manifestamos, o de linguistas, consideramos que a língua e a linguagem são fenômenos que exigem o estudo de uma equipe multidisciplinar.

O reconhecimento disso nos faz recorrer a especialistas diversos tanto para a leitura quanto para a interlocução. Consideramos essa estratégia necessária para o desenvolvimento de um trabalho que lide com a língua em uso.

Também o método deve prever um tratamento holístico na medida do possível, pois, dessa forma, as nuanças e especificidades que a complexidade do tema evidencia ou esconde serão abarcadas. Nesse sentido, cabe convidar Maturana e Varela (2001) para o diálogo, pois as ideias desses autores a respeito do método casam coerentemente com o que desenhamos como encaminhamento ideal para o fenômeno sob investigação.

Primeiro, cabe recuperar o tema desta tese e as questões nele embutidas. Iniciamos o projeto com a constatação de que indivíduos ao simbolizar, via redação dissertativa, buscam a materialização linguística por meio de construções temporais. Depois de analisar 1.600 redações produzidas em situação de alta ansiedade e notar, surpreendentemente, que as estratégias adotadas independiam da nota alcançada, postulamos que as diferenças derivariam da mobilização das categorias cognitivas de lugar e de tempo, preconizadas linearmente num encadeamento derivacional tal que nos permitiu defender que a mescla de lugar e tempo produziria espaço. Sendo assim, espaço não poderia manter a equivalência sinonímica com lugar, ou seja, espaço não poderia ser concebido como localização geográfica. 
Partindo desse pressuposto, imaginamos um modo de captar e descrever esse espaço mescla. E a resposta veio de Damásio, apresentado na seção 1.1, com sua proposta de estágios evolutivos dos selves: mente $>$ mente consciente $>$ mente consciente capaz de produzir cultura. Esses estágios, comparados à produção escrita dos participantes do processo de seleção do vestibular da FUVEST, nos remetem à mobilização de uma menor ou maior quantidade de informações culturais e consequentemente de leitura. Dessa forma, em conformação com a nossa hipótese, essa gradiência cultural mostra que o indivíduo apresenta-se em uma escala de níveis mais próximos do protosself, self central e self autobiográfico, respectivamente. Vejamos a figura:

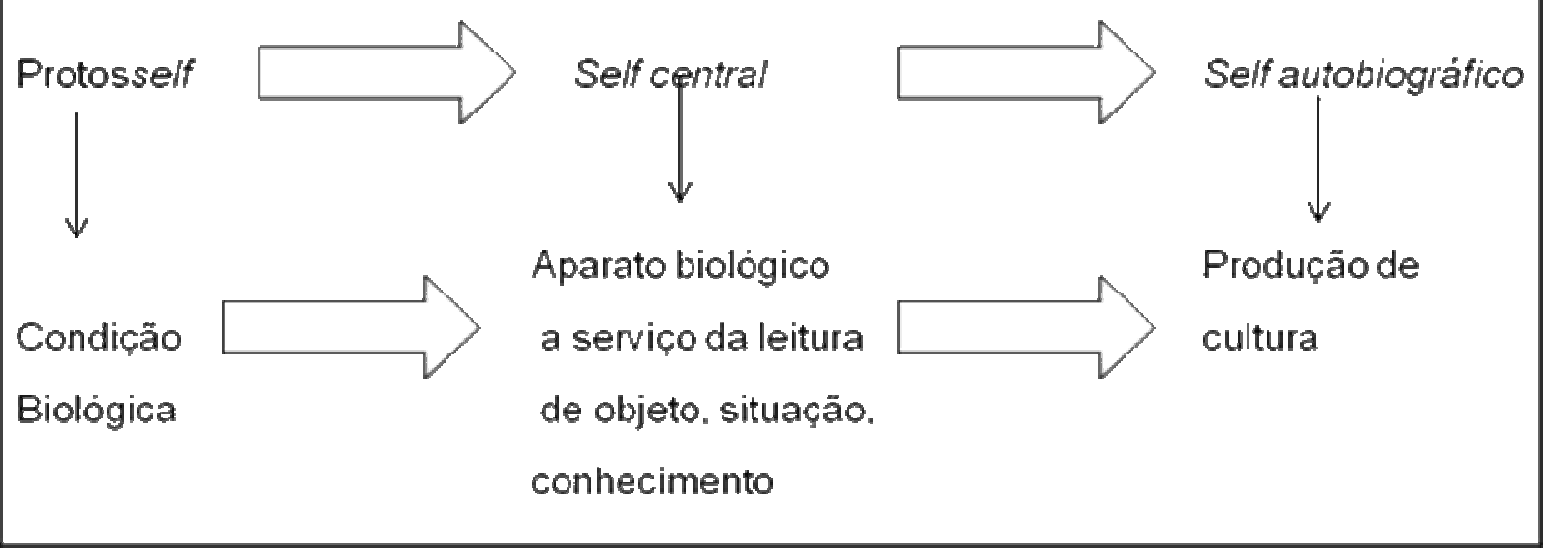

Quadro 11: Estágios dos selves e a Produção de Cultura

Essa representação inclui os estágios dos selves em um paralelo com a produção do indivíduo. Nele podemos visualizar que o primeiro estágio, o Protosself, é a condição biológica básica ao ser humano para que, em um estágio mais adiantado, o 
self central aja sobre o conhecimento, a compreensão da leitura e da situação, bem como sobre a manipulação (a exploração) do objeto, existindo a reprodução daquilo que se tem experienciado em novas situações. Por fim, no último estágio, no self autobiográfico, ocorre a produção de cultura, que envolve experienciamentos do próprio indivíduo e evidências de autoria, a partir de um posicionamento crítico-cultural. Esses estágios nos remetem a um continuum de gradação de mobilização de informações.

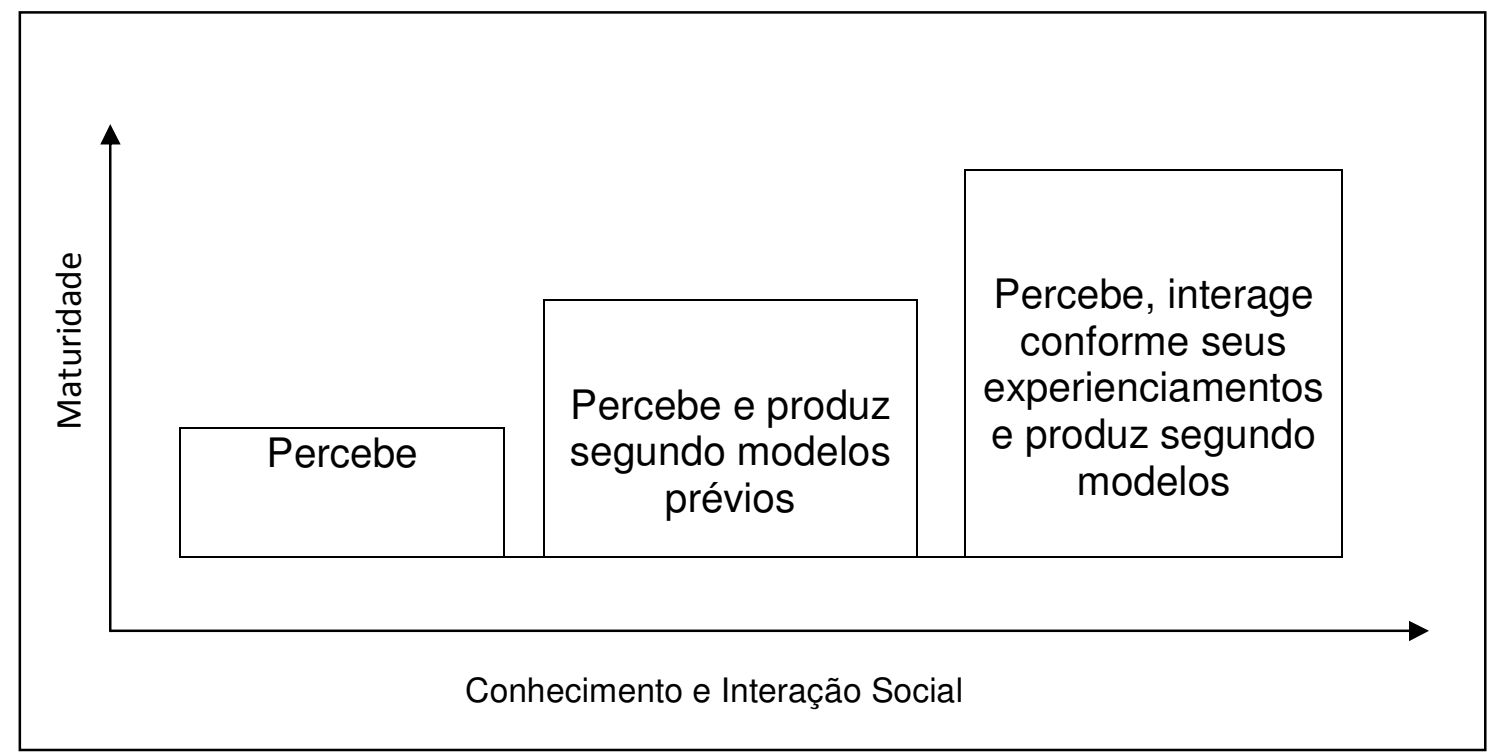

Continuum 2: Gradação de mobilização de informações

A partir dessa representação, reconhece-se que, no segundo estágio, haveria uma reprodução ou adaptação de elementos vivenciados e, no terceiro estágio, uma contribuição (inter)subjetiva a que chamamos elaboração. Como se pode depreender dessa exposição, o self e a habilidade de desenvolver textos cada vez mais complexos constituem-se exercícios processuais e dinâmicos. 
Então, uma mente mobilizada para produção de texto dissertativo, que é altamente abstrato, deve comunicar ao leitor (na situação do corpus analisado, invariavelmente, um professor de português) um mundo de certezas, de convicções, que atuam para convencer o outro de que a informação veiculada é a plausível e deve ser acreditada. Isso significa dizer que a escola ensina a convencer, a ter razão, a vencer argumentativamente, a construir estruturas textuais perfeitas. Será, contudo, que a escola ensina o indivíduo a assumir o turno linguístico, a dar início, a dar um primeiro passo discursivo numa direção? De onde virá a forma empregada pelo indivíduo para inaugurar uma proposta, para entabular uma "conversa", para quebrar o gelo numa proposta textual, que o separa no tempo e no espaço de seu interlocutor legítimo? Intuímos que isso venha de suas raízes dialógicas, o que na situação de produção de texto equivaleria às regras habituadas durante o comportamento escolar em língua portuguesa: regras gramaticais e formas textuais.

A produção textual pode ser afetada em seu processamento mental se sentimentos e emoções interseccionarem-se no campo das experiências vividas e pode se apresentar nos experienciamentos textuais. Eles equivalem não somente ao vivido, mas também aos planos futuros que não necessariamente foram realizados, mas que foram efetivamente imaginados em dado momento, passando a integrar por isso a história do indivíduo, inclusive propulsionando suas ações e vontades. Sigamos, doravante, com os ensinamentos desses caminhos trilhados por Damásio.

O self autobiográfico leva uma "vida dupla". Numa dessas vidas, produz mente consciente e também permanece latente, aguardando a vez para entrar em ação. Numa 
vida obscura e secreta, vai ganhando corpo à custa do fortalecimento de conhecimentos conquistados diariamente e reforçados por ações, eventos e objetos cotidianos. Simultaneamente, vai reelaborando a memória.

Nessa reelaboração, as substâncias vão mudando de estatuto em decorrência de reavaliações frequentes que clamam por rearranjos motivados invariavelmente por pressões emocionais. Informações guardadas e menosprezadas passam a ser desconsideradas, outras ganham em valorização a depender dos mesmos contextos de ações. A história do indivíduo vai sendo rascunhada, escrita, revisada e reescrita diariamente em função de priorizações e de experiências.

Evocações vão sendo realizadas toda vez que o self autobiográfico entra em campo. Alguns episódios são raramente evocados, outros, mais frequentemente. A complexidade desse recurso é tão grande em uns (os evocados), quanto em outros (os que ficam adormecidos).

Por isso, o caminho para a construção do self autobiográfico pressupõe o seguinte: memórias passadas, objetos, pulsos e a conformação de um padrão, conforme demonstra Damásio no quadro que reproduzimos a seguir: 


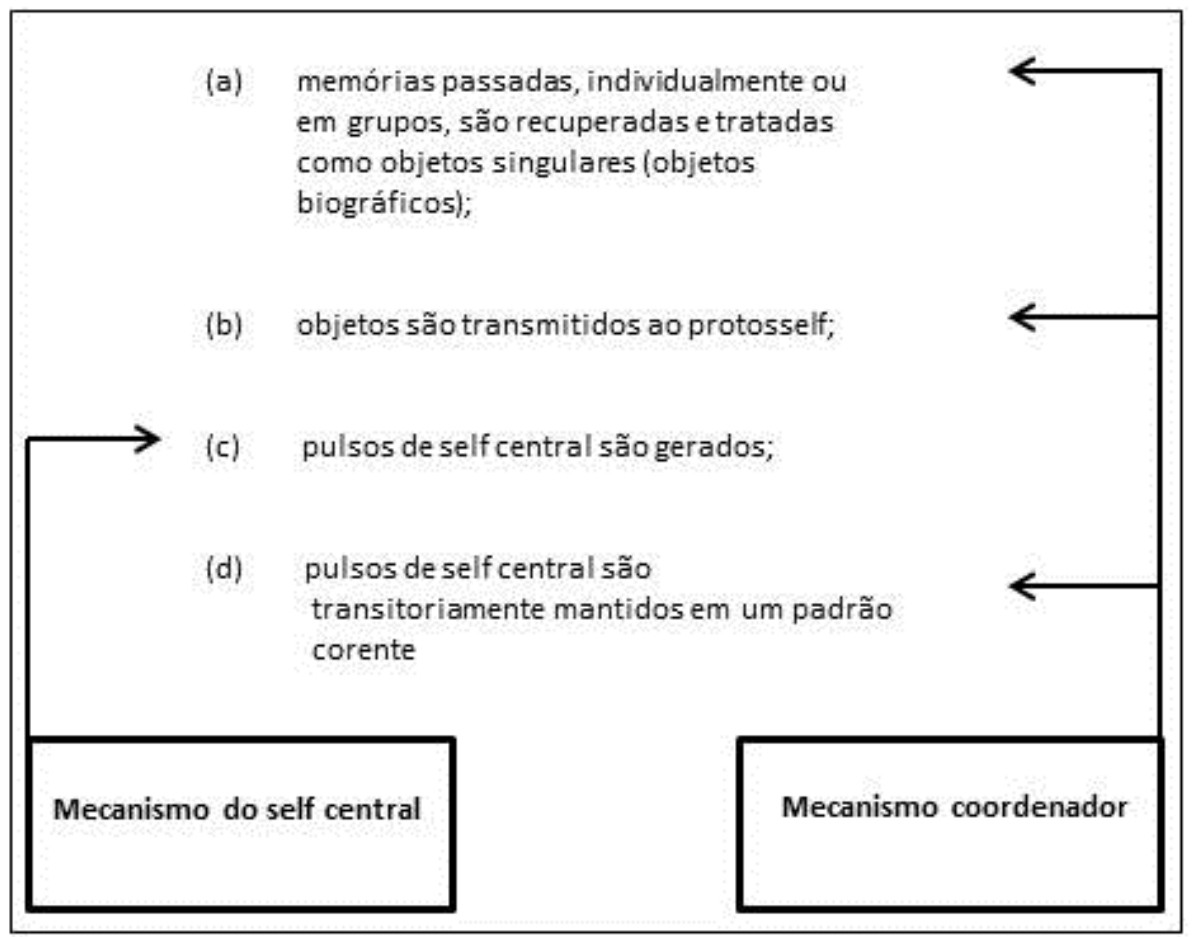

Quadro 12: O self autobiográfico e os mecanismos neurais (Damásio, 2011, p.263)

Ainda inspirados no mesmo autor, verificamos que o procedimento que envolve esses mecanismos neurais pressupõem o seguinte:

1. Conjuntos substanciais de memórias biográficas devem ser agrupados de modo que cada um possa ser prontamente tratado como um objeto individual;

2. Cada objeto apreendido modifica o protosself e produz seu pulso de self central, permeado dos sentimentos de conhecer; 
3. O cérebro conta com mecanismos capazes de coordenar a evocação de memórias, transmitindo-as ao protosself para a interação. Os resultados disso são mantidos em um padrão coerente ligado aos objetos causativos;

4. Pulsos de self central, via procedimentos neurais, são mobilizados para um número substancial de componentes, e os resultados tendem a ser coordenados;

5. As imagens precisam interagir com os processos do protosself, que está em boa parte localizado no nível do tronco cerebral, ou seja, mais enraizado no indivíduo.

Muitos são os caminhos percorridos para dar conta do indivíduo em sua ação de produzir o texto. Muitos são os caminhos percorridos para dar conta da forma como o indivíduo inicia uma proposta textual. Muitos foram os caminhos para reconhecer que parte do texto dissertativo propiciaria alcançar, de forma mais eficiente, o self em seus estágios de demonstração via linguagem.

E a pergunta ecoou por algum tempo: como integrar toda essa diversidade de conhecimento e propostas, superficialmente tão díspares? A chegada de Maturana e Varela (2001:32) permitiu a percepção de que todo o conhecimento humano deve ser integrado, porque "todo fazer é um conhecer e todo conhecer é um fazer" e "tudo o que é dito é dito por alguém". A concordância com essas premissas nos faz carregar, a reboque, as seguintes ideias desses mesmos autores:

a) não há descontinuidade entre o social, o humano e suas raízes biológicas (id., p. 33); 
b) a manutenção dos organismos como sistemas dinâmicos em seu meio aparece como centrada em uma compatibilidade organismo/meio. É o que chamamos de adaptação ${ }^{34}$ (id., p. 115);

c) a característica-chave da linguagem [é] modificar de maneira tão radical os domínios comportamentais humanos, possibilitando novos fenômenos, como a reflexão e a consciência (id., p. 232);

d) mantemos uma contínua recursão descritiva - a que chamamos de "eu" -, que nos permite conservar nossa coerência operacional linguística e nossa adaptação ao domínio da linguagem ( id., p. 254);

e) as palavras são ações, e não coisas que passam daqui para ali. É nossa história de interações recorrentes que nos permite um efetivo acoplamento estrutural interpessoal. Permite-nos, também, descobrir que compartilhamos um mundo que especificamos em conjunto, por meio de nossas ações (id., p. 255);

f) o aparecimento da linguagem no homem, e também no contexto social em que ela surge, gera o fenômeno inédito [...] do mental e da autoconsciência como a experiência mais íntima do ser humano. Sem o desenvolvimento das estruturas adequadas, não é possível entrar no domínio humano (id., p. 256); e

g) a bagagem de regularidades próprias do acoplamento de um grupo social é sua tradição biológica e sua cultura. (id., pp. 264-5).

Selecionamos esses 7 itens, que representam uma visão holística da linguagem, também para evidenciar a confluência entre essa abordagem e a neurocientífica, tal como concebida por Damásio. É claramente perceptível a presença da linha evolutiva que parte de um protosself, enriquece-se com um self central e atinge seu ápice com um self autobiográfico.

\footnotetext{
${ }^{34}$ Grifo nosso: notamos aqui a convergência entre esses autores e Damásio (2011), quando trata do self central.
} 
Essas ideias culminam com algumas decisões metodológicas baseadas em algumas pistas de encaminhamentos oferecidas por Maturana e Varela (2001). Vejamos alguns desses argumentos:

a) os fenômenos que vemos como aleatórios fazem de nós observadores incapazes de propor para eles um sistema explicativo científico (id., p. 138); [aleatoriedade]

b) há circunstâncias [...] em que podemos aplicar uma descrição semântica a um fenômeno social [...], [posto que] dois ou mais organismos, ao interagir de modo recorrente, geram um acoplamento no qual se envolvem reciprocamente na realização de suas respectivas autopoieses. (id., pp. 228-9);[aspectos semânticos]

c) toda tradição se baseia naquilo que uma história estrutural acumulou como óbvio, como regular, como estável, e a reflexão que permite ver o óbvio só funciona com aquilo que perturba essa regularidade. (id., p. 265); [regularidade/estabilidade]

d) o conhecimento do conhecimento obriga-nos a assumir uma atitude de permanente vigília contra a tentação da certeza, a reconhecer que nossas certezas não são provas da verdade, como se o mundo que cada um visse fosse o mundo e não um mundo que construímos juntamente com os outros. (id., p. 267). [vigília/atenção]

Esses argumentos justificam as razões de, no capítulo 3, apresentarmos "escolhas" que dessem conta da aleatoriedade do uso e do valor semântico carreado no contexto social de produção dissertativa. Essas decisões favorecerão, neste capítulo, a apreensão das regularidades e estabilidades que guiaram a atenção dos candidatos da FUVEST. 


\subsection{Iniciar é a parte mais difícil}

Perguntamo-nos sobre qual tipo de contexto é criado pelos candidatos para dar início a uma redação, porquanto muitos manifestam uma grande dificuldade de dar o primeiro passo na escrita. Esse questionamento tem amparo em questões discutidas no capítulo I, quando afirmamos que a linguagem verbal e também a corporal expressam, na medida do possível, o mundo mental. Ocorre que, na modalidade escrita, isso tudo é reconstruído ao sabor da (inter)subjetividade. Por que isso ocorre seria uma boa pergunta. E a resposta é clara: agimos assim, porque fazemos melhor aquilo que já conhecemos e, consequentemente, ganhamos mais habilidades.

Ao analisarmos as redações produzidas pelos candidatos da FUVEST, percebemos que o padrão criado por eles para a construção do primeiro parágrafo indifere no que se refere às categorias cognitivas subjacentes. Três categorias são contempladas pelos candidatos: lugar, tempo e espaço.

A distribuição dessas categorias no corpus sob análise podem ser representadas em gráficos, como fizemos e apresentaremos adiante, pois com esses instrumentos torna-se perceptível que há um espaço seguro para a construção de uma tese forte. Trataremos dessa questão ao final da descrição.

Com a proposta de 2004, que trata do estatuto da história como dinâmica temporal, associado à angústia e à fugacidade do tempo, esperávamos que os textos 
dos candidatos projetassem as categorias de tempo e de espaço como fundo de tese. Verificamos que essa constatação ganha eco na análise dos primeiros parágrafos.

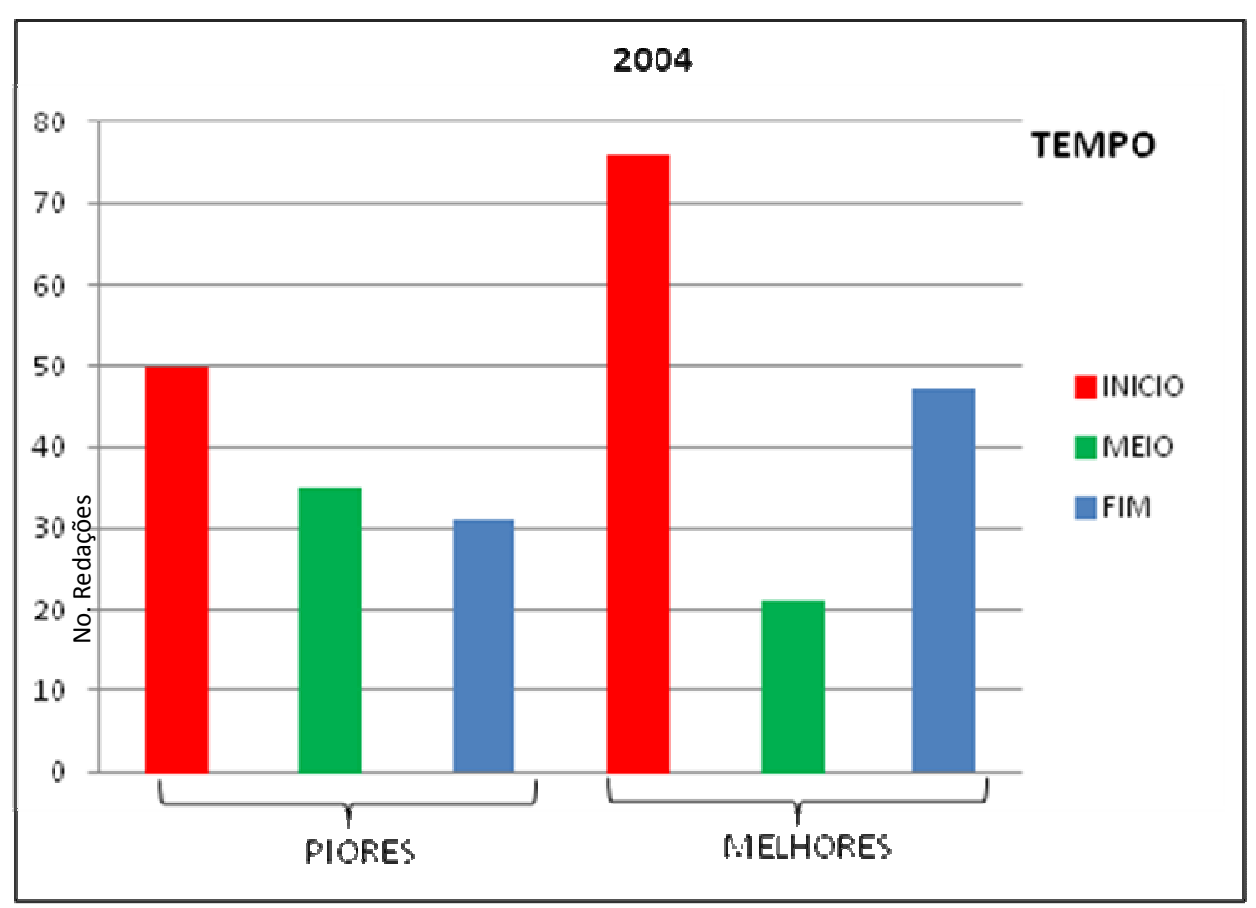

Gráfico 1: Ano 2004 - Localização das expressões temporais

Tanto nas melhores quanto nas piores redações, as categorias de tempo e lugar, conforme vemos nos gráficos 1 e 2, ambos do ano de 2004, são topicalizadas para servir de fundo para a construção da tese. Expressões temporais, tais como a cada minuto, há quinze anos e cada dia mais e locativas, como Avenida Paulista e o mundo representam unidades temporais e geográficas vagas que pouco contribuem efetivamente para o fortalecimento da tese, no entanto garantem um lugar seguro para iniciar uma interação. Nesse quesito, não se diferenciam talentos para a escrita, mas 
evidenciam-se habilidades angariadas durante a ontogênese: a capacidade de interagir criando um espaço conjunto de atenção.

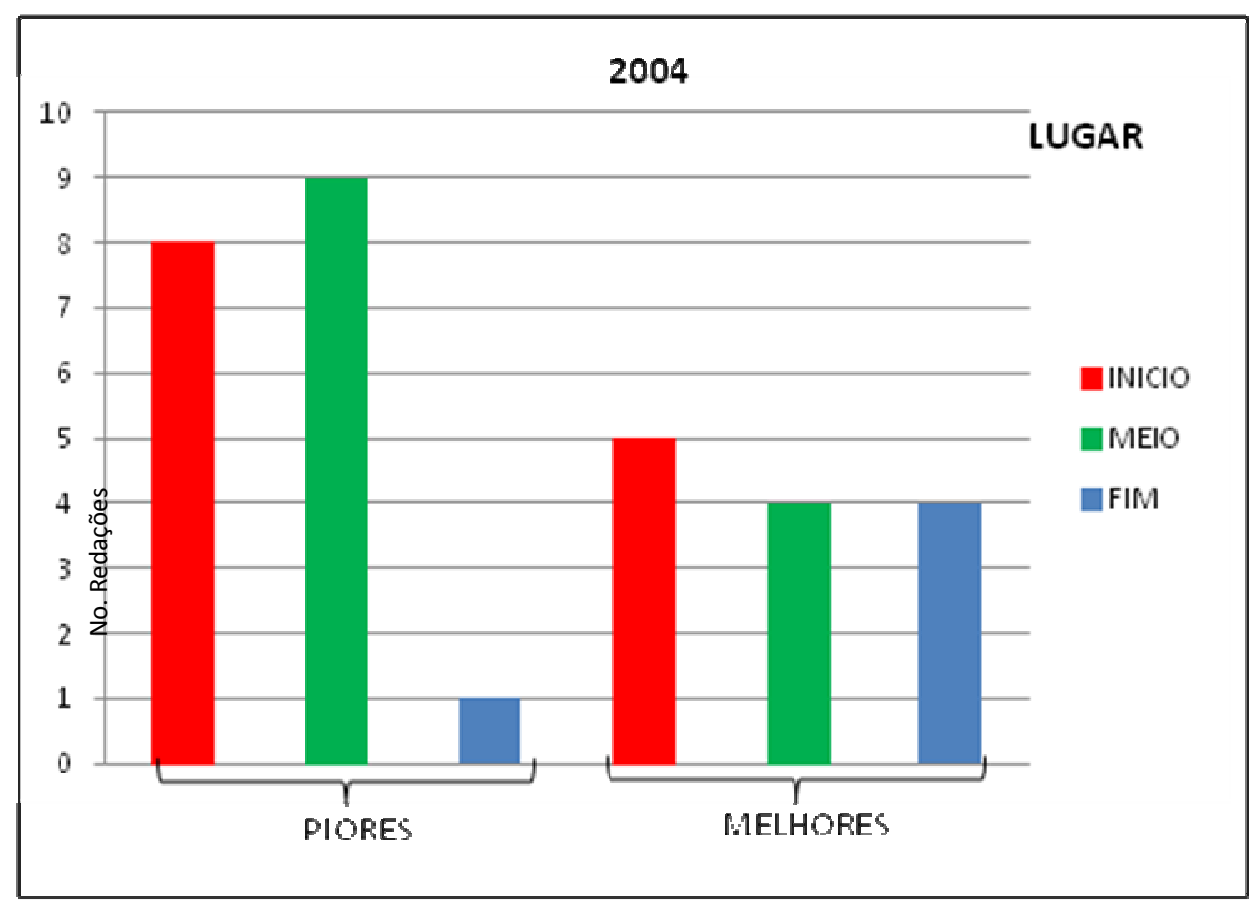

Gráfico 2:Ano 2004 - Expressões locativas topicalizadas e focalizadas

Ainda em 2004, analisamos juntas as expressões locativas e temporais, como, por exemplo, o mundo a cada momento e o mundo contemporâneo as quais não se encontraram em posição medial. No caso das melhores redações, há uma equalização entre as ocorrências tempo/lugar que surgiram no início e no fim; já nas piores foram mais frequentes as ocorrências topicalizadas. Também foi observado que houve maior recorrência das expressões de tempo/lugar nas melhores redações. 


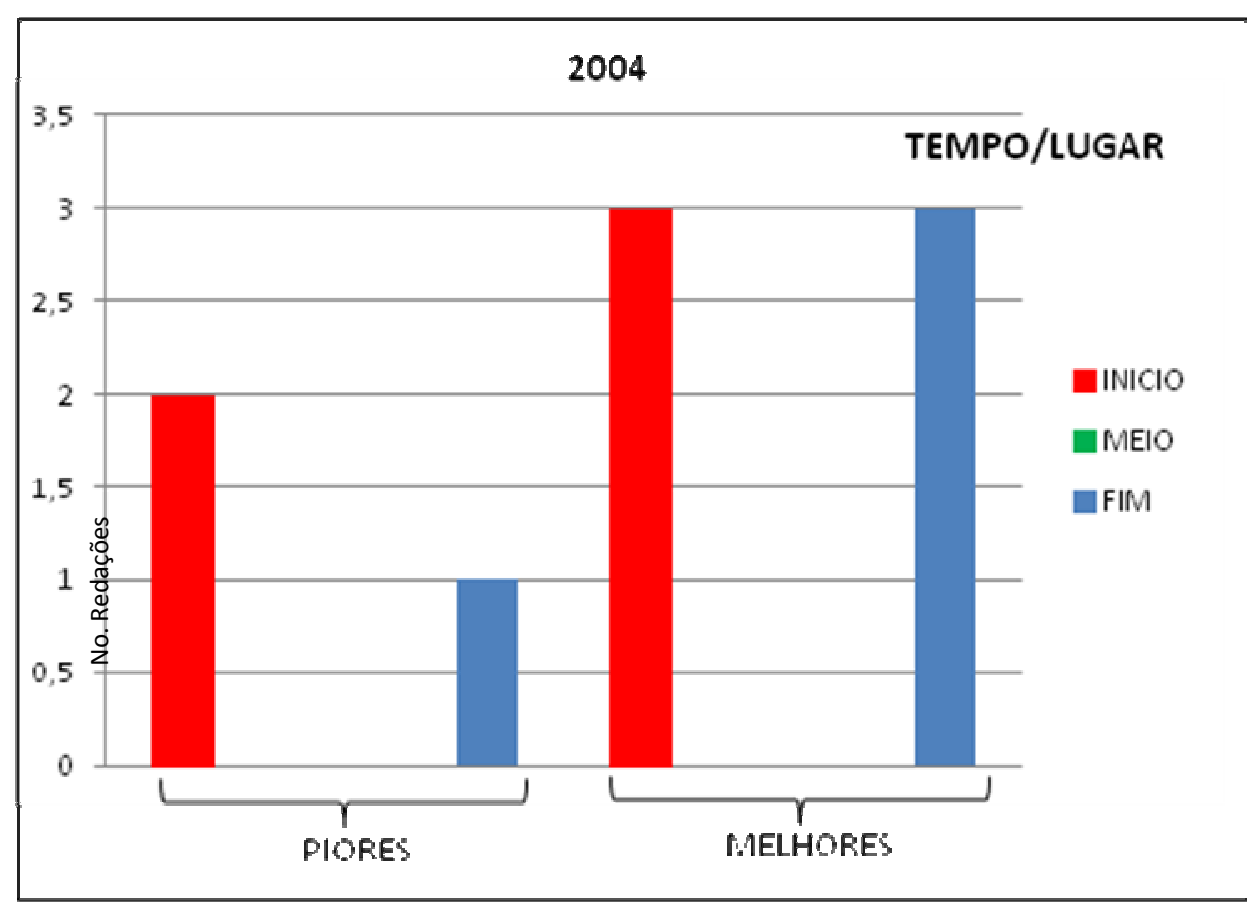

Gráfico 3: Ano 2004 - Expressões temporais e locativas topicalizadas e focalizadas

No ano de 2005, em que a abordagem temática solicita ao candidato um ponto de vista acerca de um controle ideológico, que se apresenta materializado em forma de uma catraca apresentada no texto I, de acordo com o gráfico 4, a categoria de tempo topicalizado foi mais frequente em ambas as redações. Foram recorrentes expressões, como hoje em dia, durante os primórdios dentre outras de mesma natureza. 


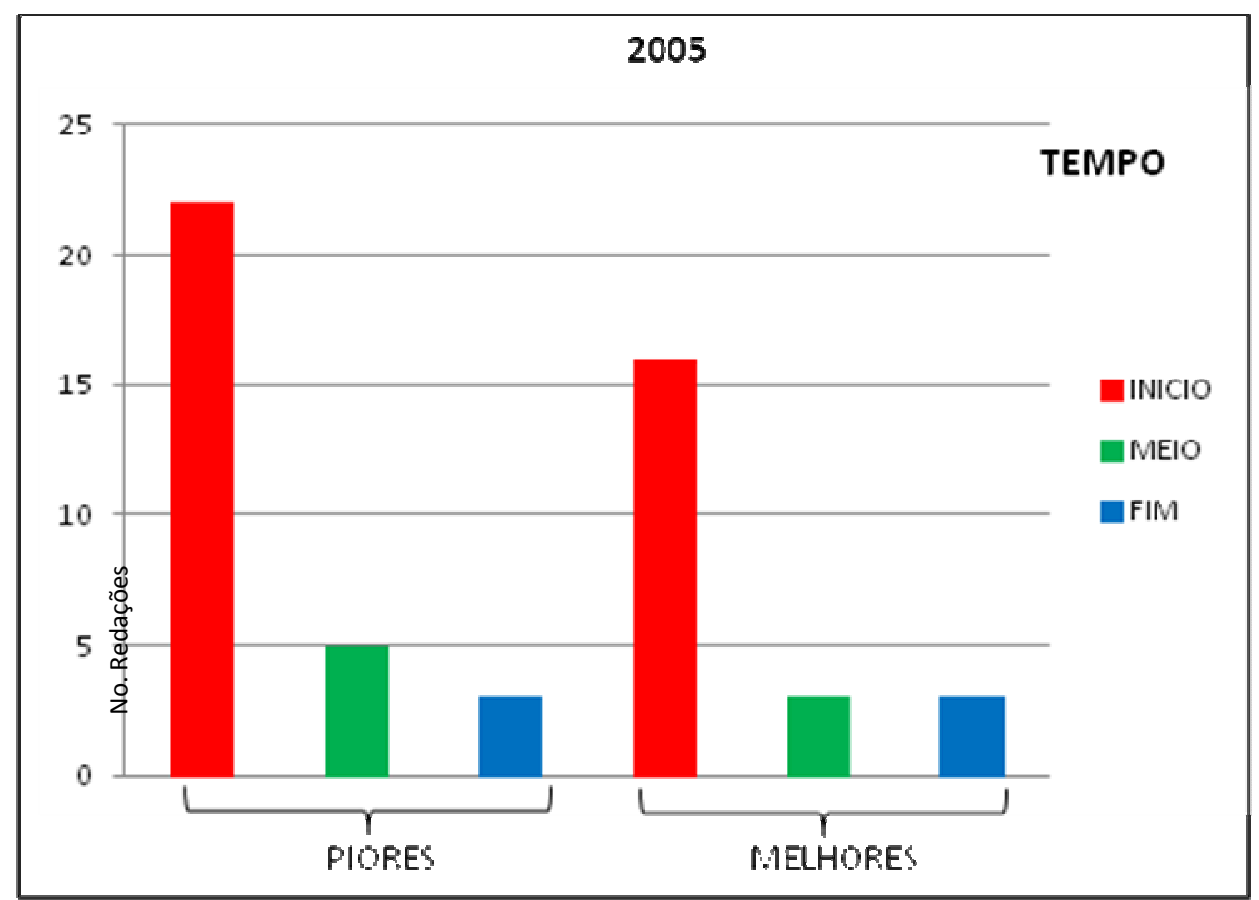

Gráfico 4: Ano 2005 Expressões temporais topicalizadas e focalizadas

No que tange a lugar, em 2005, houve uma discrepância entre as melhores e piores redações, pois, enquanto no primeiro parágrafo das piores tivemos um alto índice de recorrência topicalizadas, nas piores redações o destaque foi para os dados focalizados na posição final do parágrafo. Para ambos os casos, as expressões que se apresentaram foram Brasil, mundo, Centro de tradições nordestinas, São Paulo entre outras. 


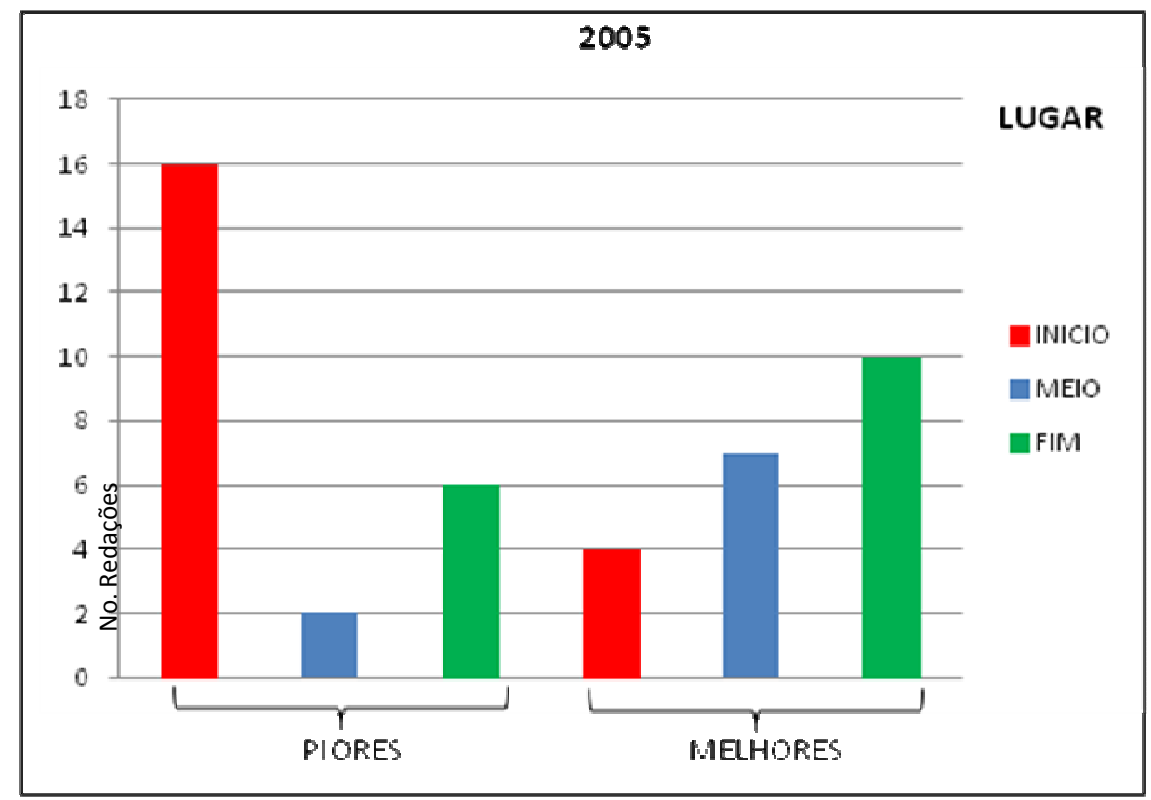

Gráfico 5: Ano 2005 - Expressões locativas topicalizadas e focalizadas

Observemos, no gráfico 6 , também do ano de 2005, a representação da distribuição quantitativa das expressões locativas e temporais conjuntamente.

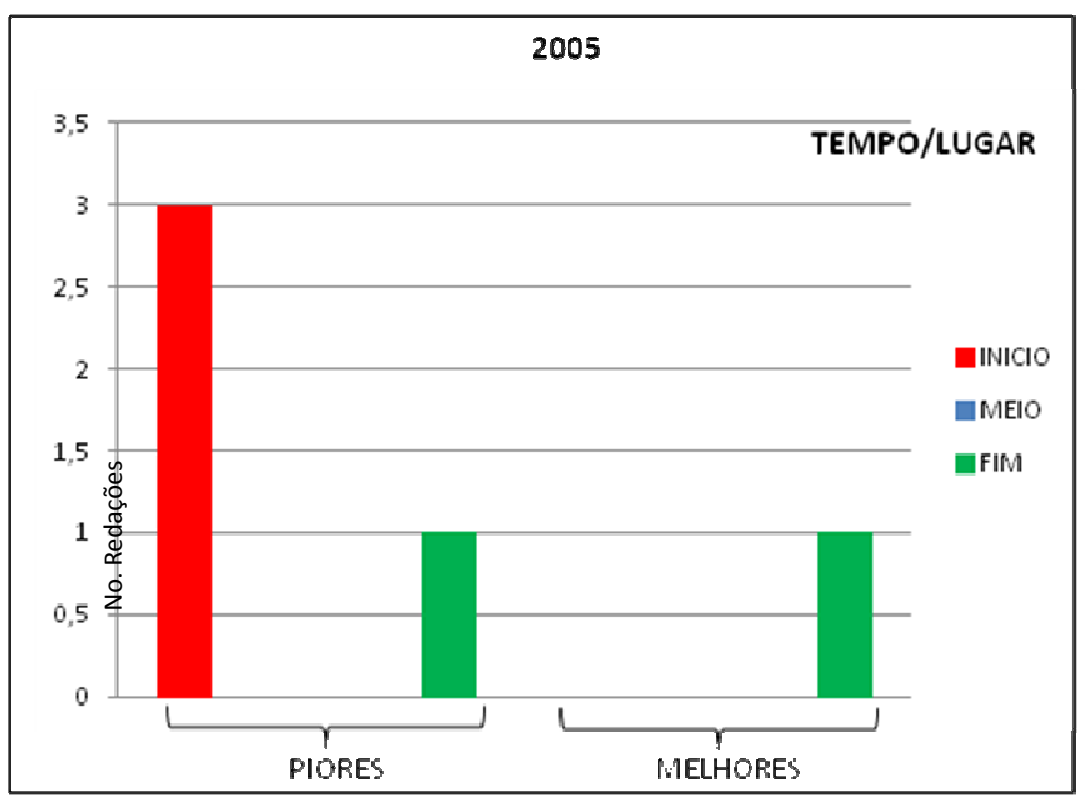

Gráfico 6: Ano 2005 - Expressões temporais e locativas topicalizadas e focalizadas 
Semelhantemente ao ocorrido em 2004, não foram registradas ocorrências de tempo/lugar em posição medial. Em contrapartida, tivemos um alto índice de dados topicalizados nas piores. Novamente expressões, como mundo de hoje e mundo contemporâneo surgiram.

Em 2006, transformação e mudanças estão presentes nos textos que contribuem para a elaboração da dissertação. Diante disso, já esperávamos que os candidatos buscassem as referências temporais e locativas para dividir com o interlocutor o espaço da atenção conjunta, uma vez que o próprio tema contribuía para esse fator.

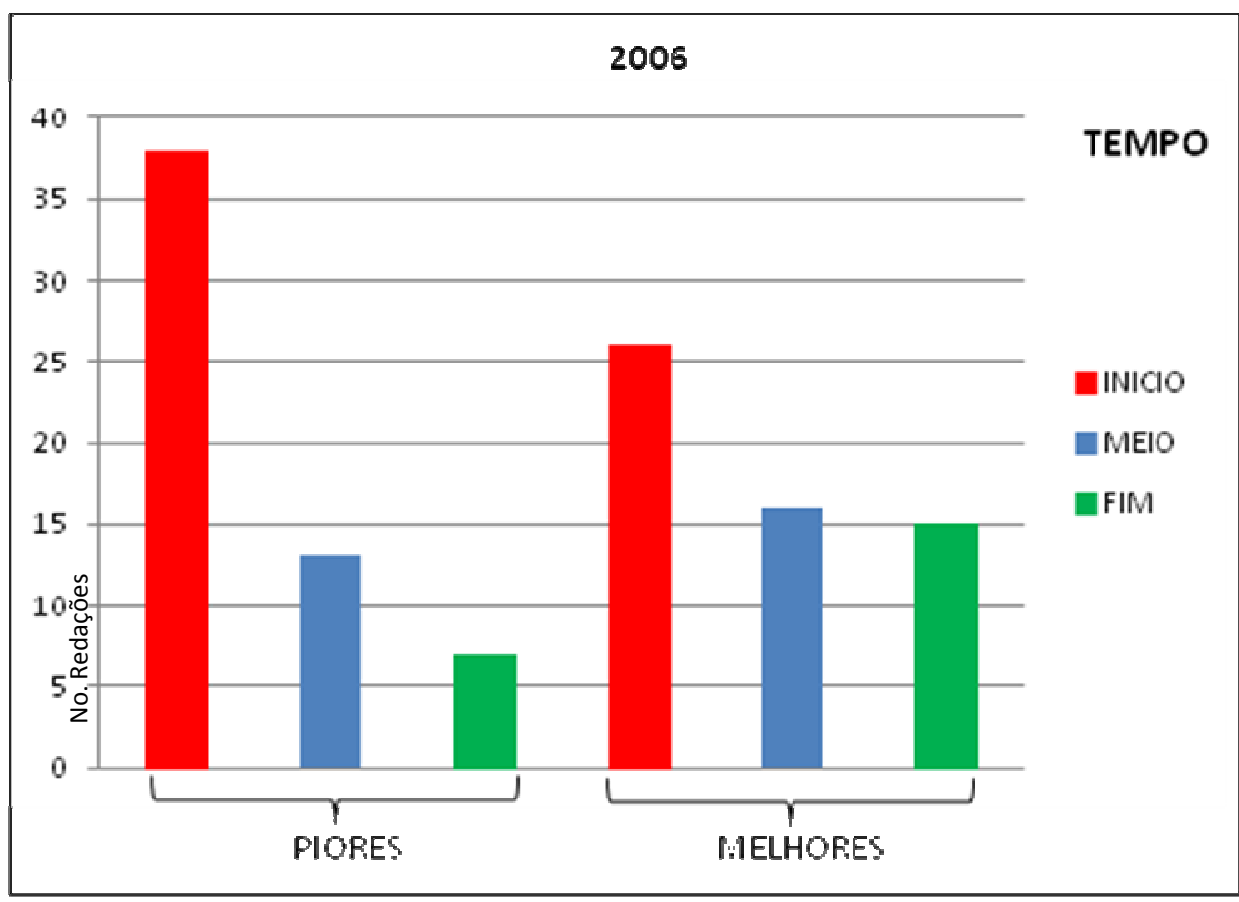

Gráfico 7: Ano 2006 - Expressões temporais topicalizadas e focalizadas 
O gráfico 7 confirma um alto índice de expressões temporais utilizadas, bem como um maior número delas topicalizadas. Também, observamos, ainda no gráfico 8 , que as expressões de lugar, embora haja um alto índice de ocorrências topicalizadas tanto nas piores quanto nas melhores redações, no caso desta última a posição medial se destaca.

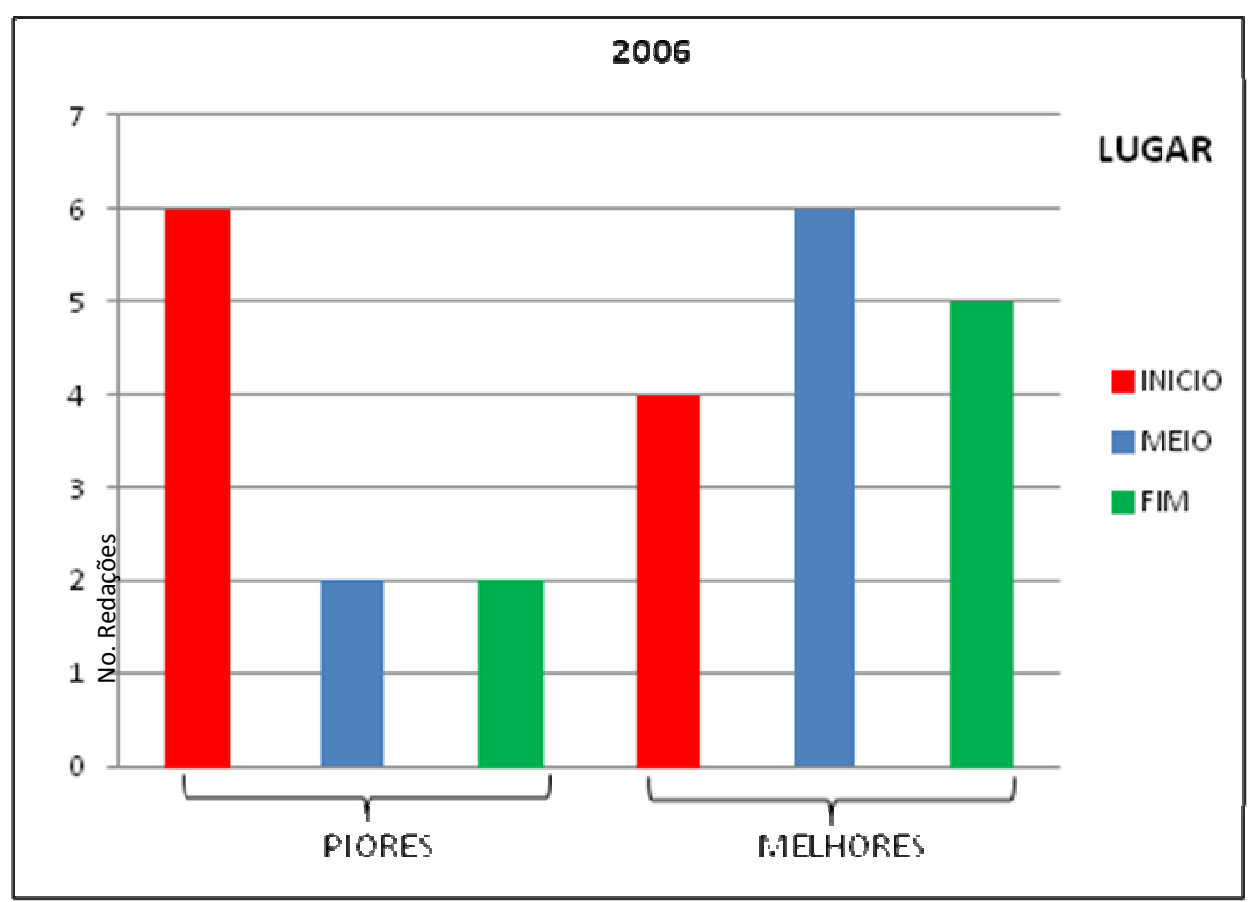

Gráfico 8: Ano 2006 - Expressões locativas topicalizadas e focalizadas

No que tange a tempo/lugar, em 2006 essas categorias organizam-se topicalizadas na estrutura do parágrafo. É o que apresentamos no gráfico 9. 


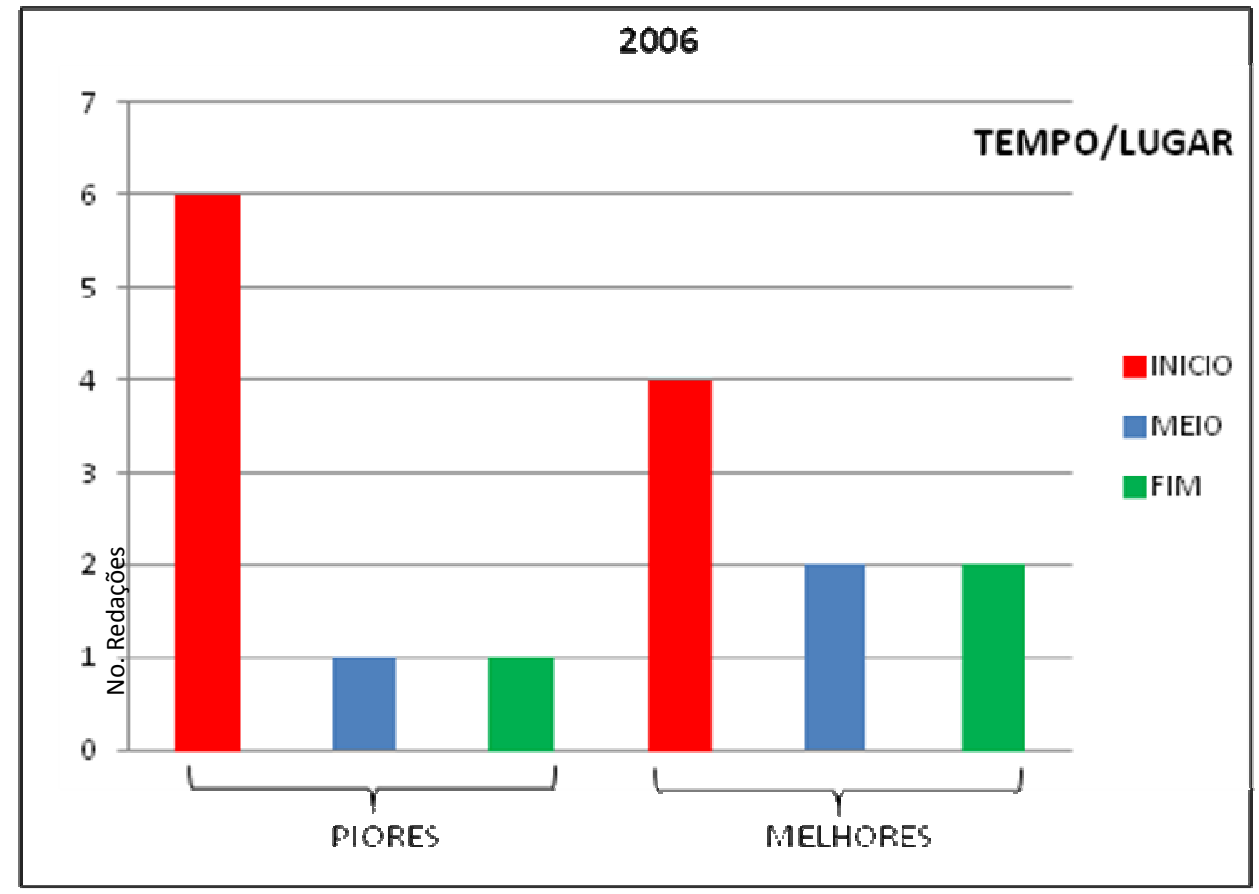

Gráfico 9: Ano 2006 - Expressões temporais e locativas topicalizadas e focalizadas

Em 2007, o apreço entre as pessoas é discutido a partir de textos de filósofos como Cícero e Montaigne e das letras de canções de Fernando Brant, Milton Nascimento e Caetano Veloso. Como mencionado no capítulo III, acreditávamos que o tema favorecesse a topicalização de expressões temporais e locativas, no entanto, apesar de termos um número significativo de ocorrências topicalizadas, o destaque nesse ano foi para a localização medial de termos temporais e locativos, de acordo com que representamos por meio dos gráficos 10 e 11 . 


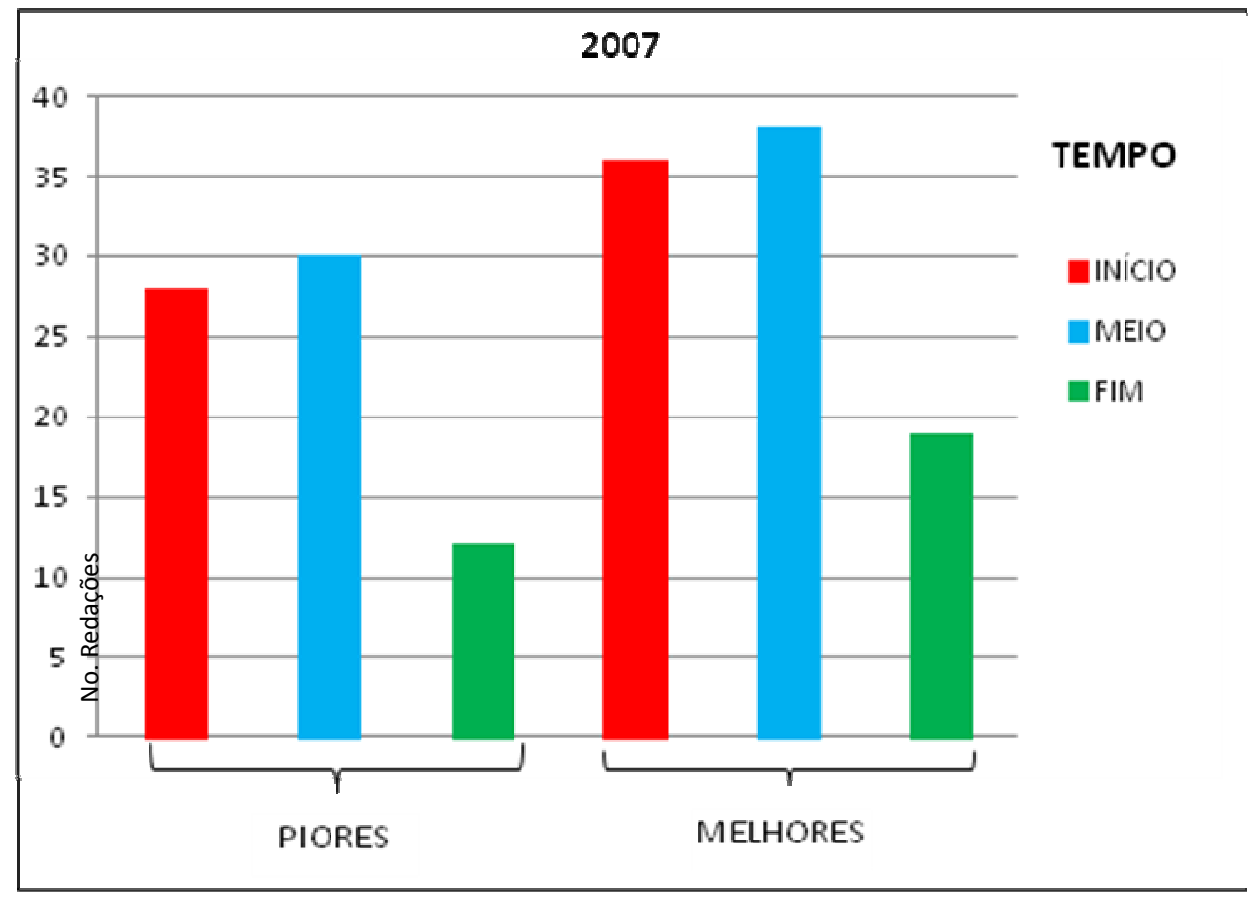

Gráfico 10: Ano 2007 - Expressões temporais topicalizadas e focalizadas

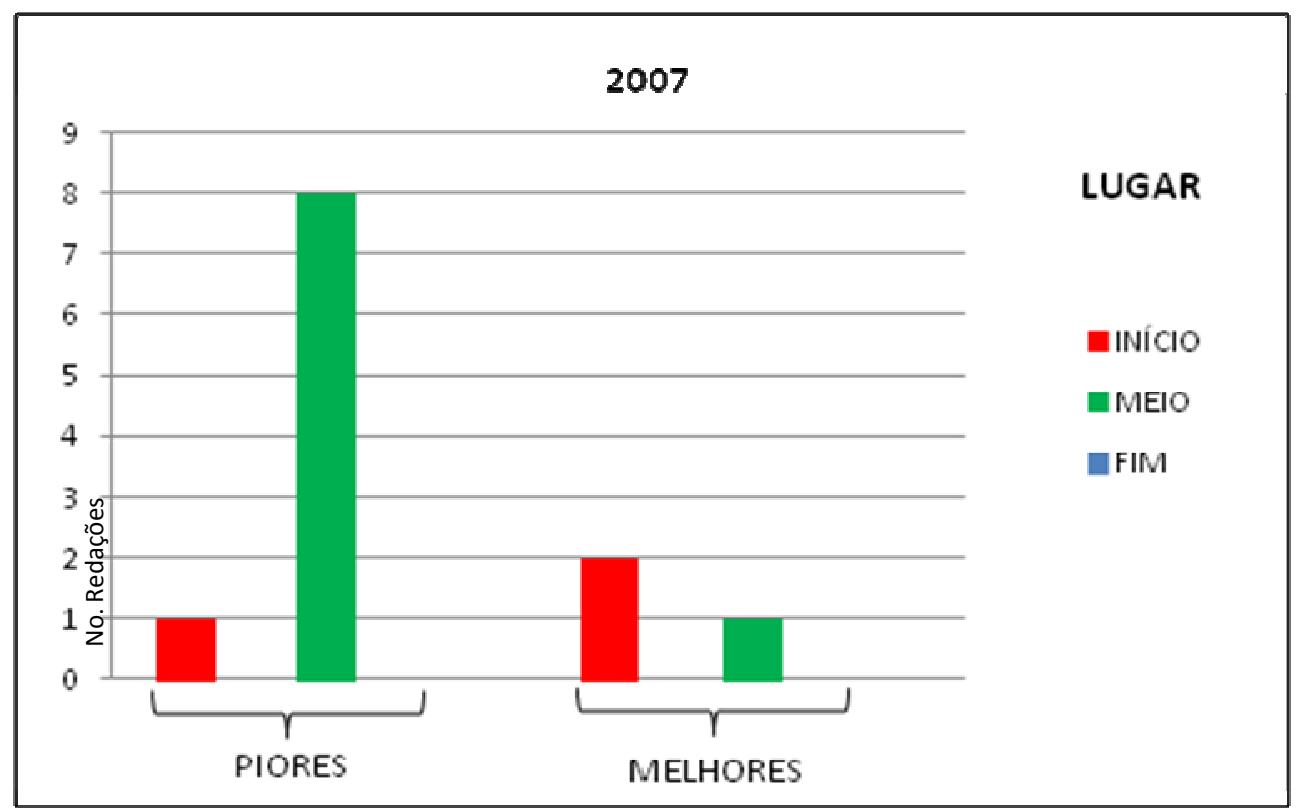

Gráfico 11: Ano 2007 - Expressões locativas topicalizadas e focalizadas 
Ainda em 2007, tempo e lugar juntos não apareceram em posição final e, no caso das melhores redações, tiveram maior índice de ocorrências na posição medial. Por outro lado, nenhum dado em posição medial foi empregado nas redações classificadas como piores. São exemplos de expressões que indicam as duas categorias, simultaneamente, mundo em que vivemos hoje e Grécia em que vivemos.

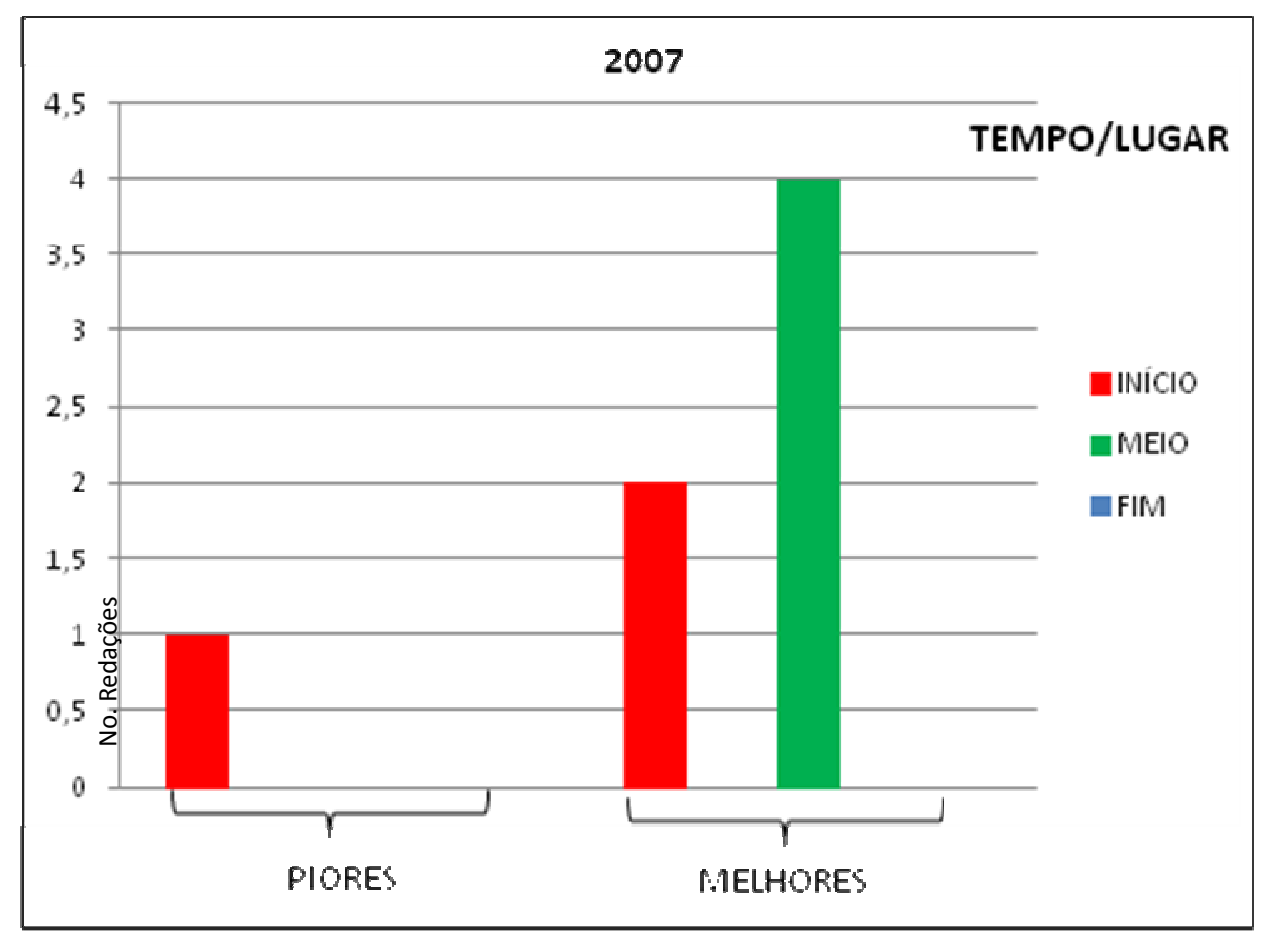

Gráfico 12: Ano 2007 - Expressões temporais e locativas topicalizadas e focalizadas

Em 2008, o panorama de tempo e espaço é apresentado por uma abordagem que envolve a temática do mundo digital. No que se refere ao tempo, conforme o gráfico 13, é mais recorrente na sua posição topicalizada tanto nas melhores quanto nas piores redações. Contudo, a categoria de lugar, nesse ano, foi mais recorrente em 
posição medial, tal como permitem reconhecer as informações representadas o gráfico 14.

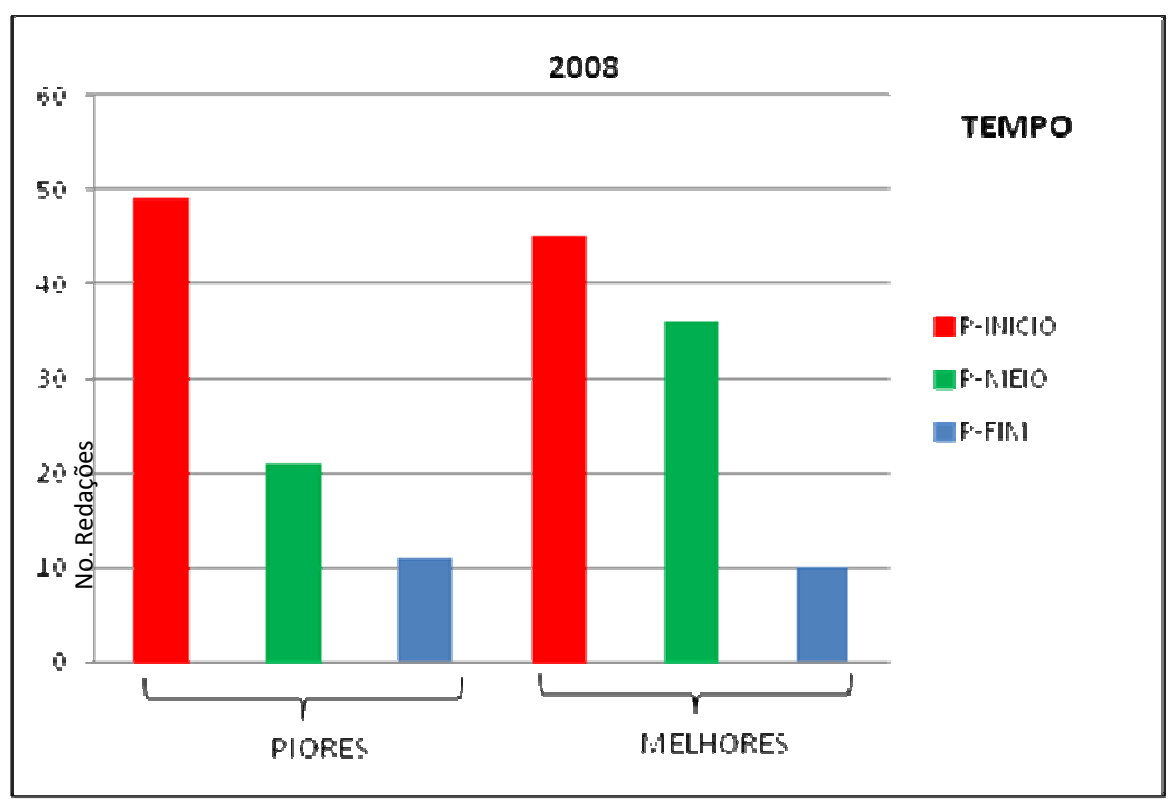

Gráfico 13: Ano 2008 - Expressões temporais topicalizadas e focalizadas

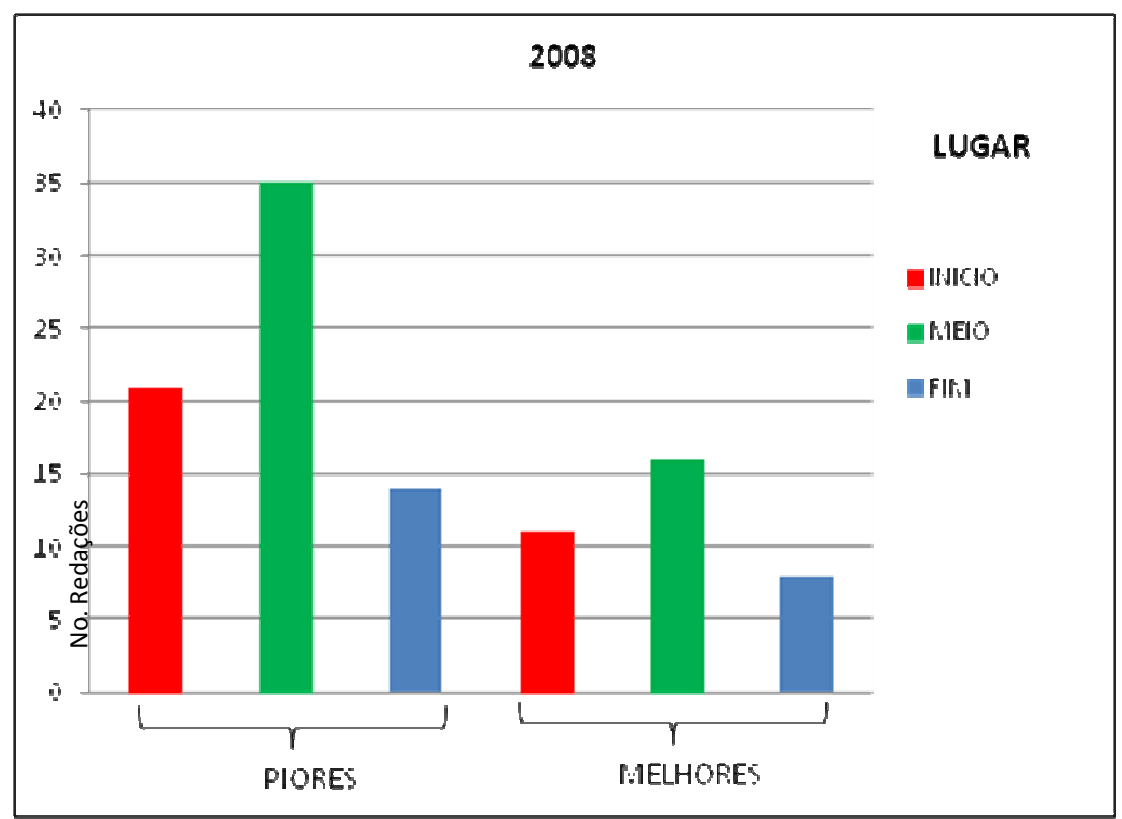

Gráfico 14: Ano 2008 - Expressões locativas topicalizadas e focalizadas 
Já em tempo e lugar simultaneamente, nas piores redações essas categorias foram topicalizadas e, nas melhores, foram identificadas focalizadas em posição final.

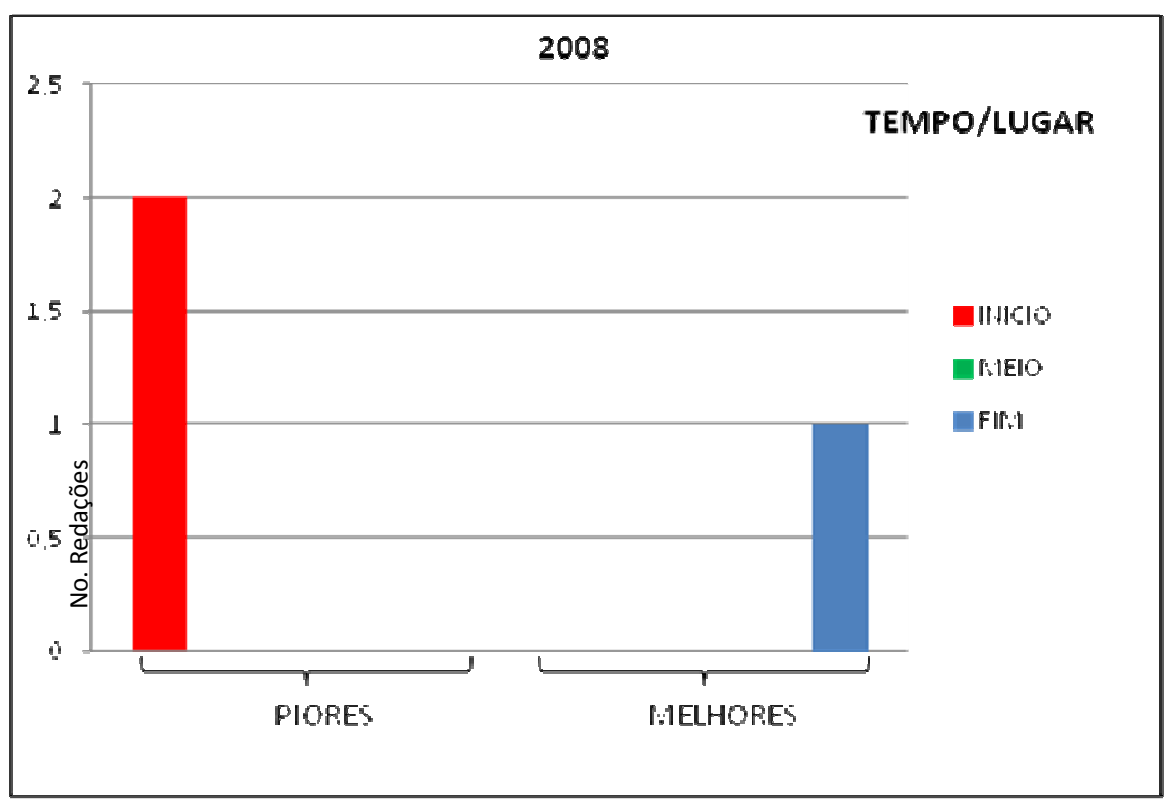

Gráfico 15: Ano 2008 - Expressões temporais e locativas topicalizadas e focalizadas

Na proposta de 2009, a partir do conceito da palavra fronteira, que é apresentado pelos textos motivadores, tanto em seu sentido denotativo quanto conotativo, contribuem para que o candidato construa um posicionamento crítico acerca de questões político-sociais. Com base no gráfico 16, a categoria de tempo topicalizada se sobressai em relação às demais posições. 


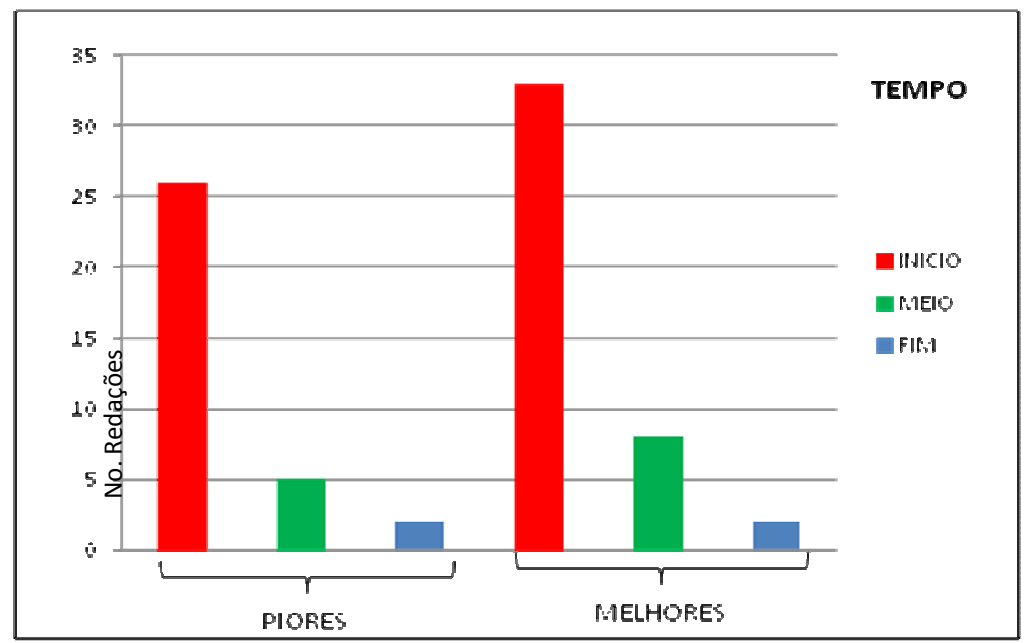

Gráfico 16: Ano 2009 - Expressões temporais topicalizadas e focalizadas

No que tange à categoria de lugar, baseado no gráfico 17, percebemos que a posição medial teve maior representatividade tanto nas melhores redações quanto nas piores, no caso desta última, a diferença foi bem significativa. Em relação as demais posições.

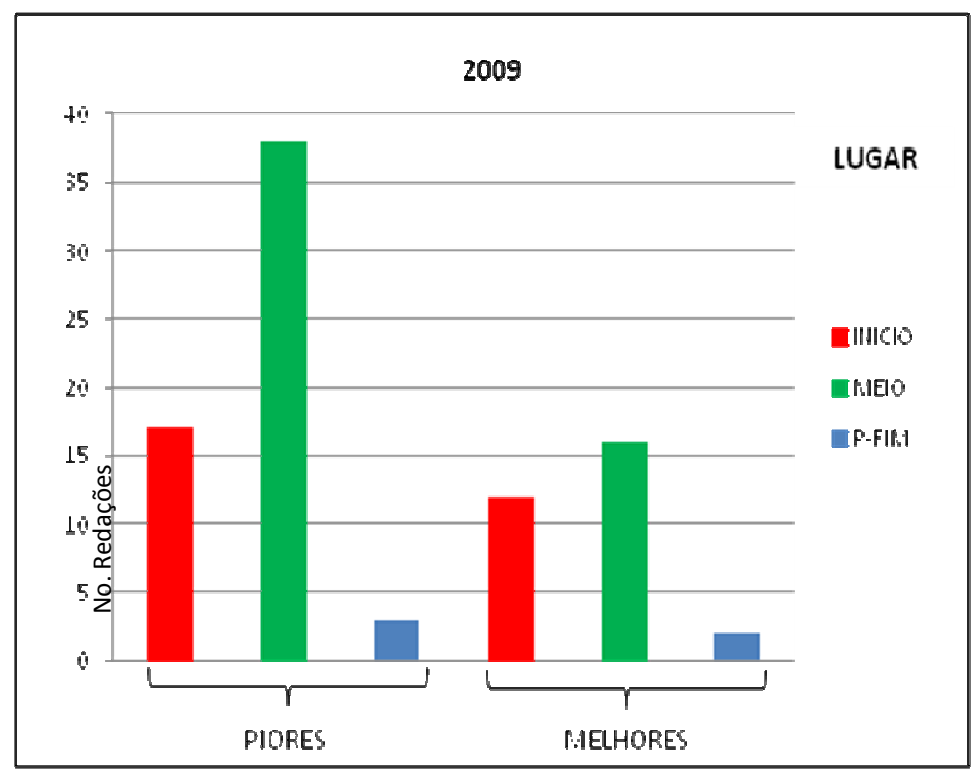


Gráfico 17: Ano 2009 - Expressões locativas topicalizadas e focalizadas

Já para tempo e lugar, de acordo com o gráfico 18, só tivemos ocorrências topicalizadas. No entanto,em relação às piores redações, tivemos um número maior de ocorrências significativo nas redações classificadas de melhores.

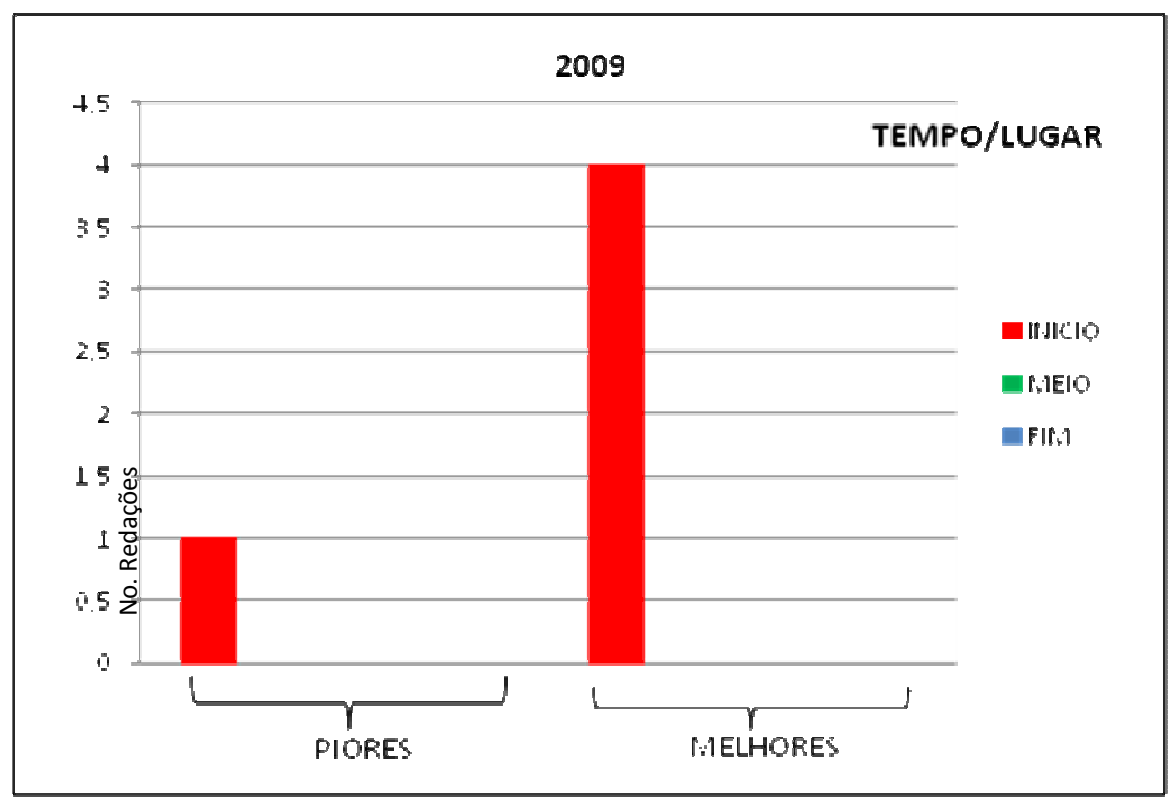

Gráfico 18: Ano 2009 - Expressões temporais e locativas topicalizadas e focalizadas

Em 2010, em que os textos motivadores apontam a oposição entre o equilíbrio que é dado pela imaginação e a realidade da vida diária. É nessa relação paradoxal que o candidato divide com o leitor o espaço de atenção conjunta. As redações analisadas mostraram que houve um destaque para o uso da posição topicalizada das categorias de tempo (gráfico 19) e de lugar (gráfico 20). No caso desta última, conforme observamos no gráfico 20 as melhores redações ficaram equalizadas em relação à topicalização e à posição medial. 


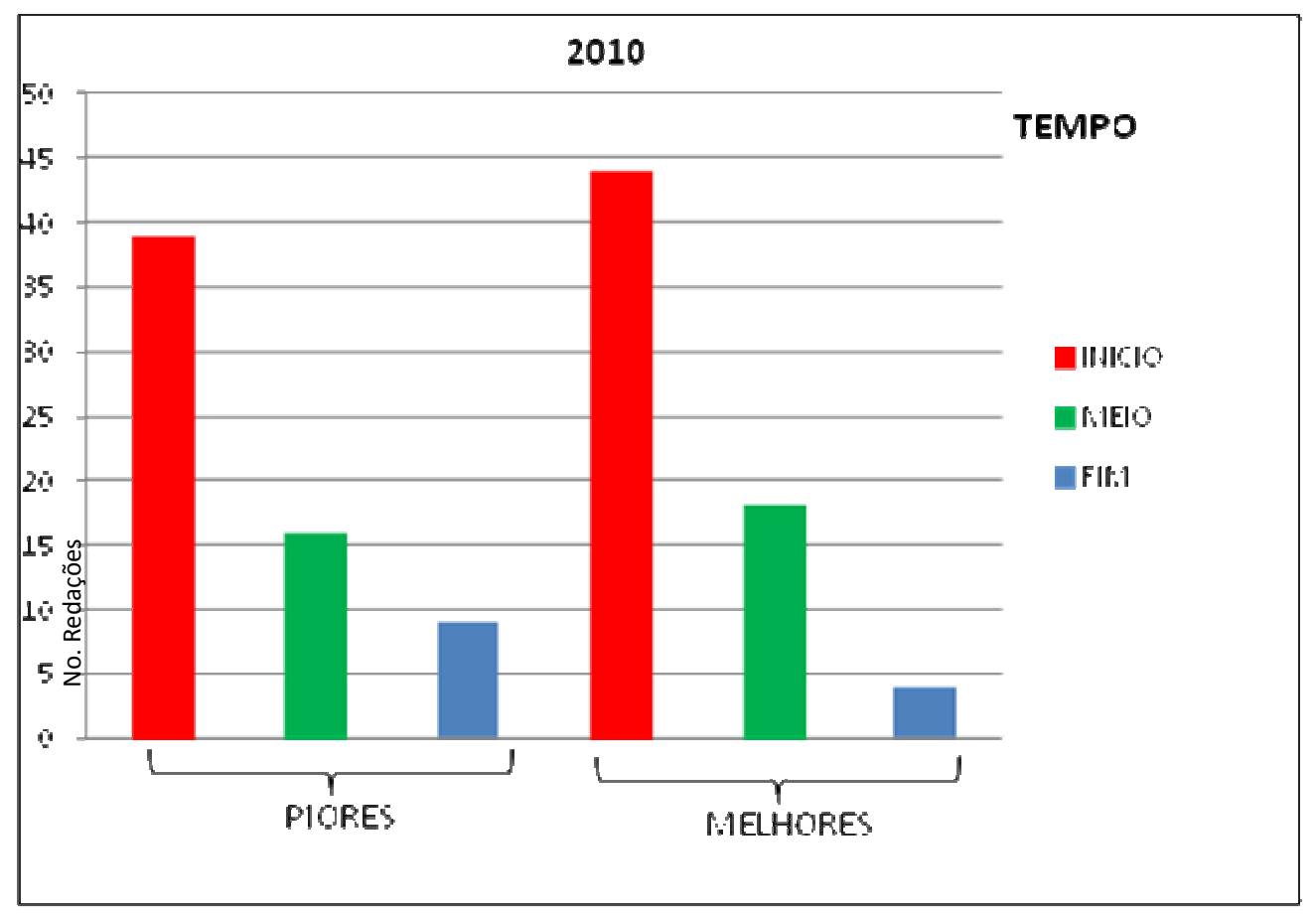

Gráfico 19: Ano 2010 - Expressões temporais topicalizadas e focalizadas

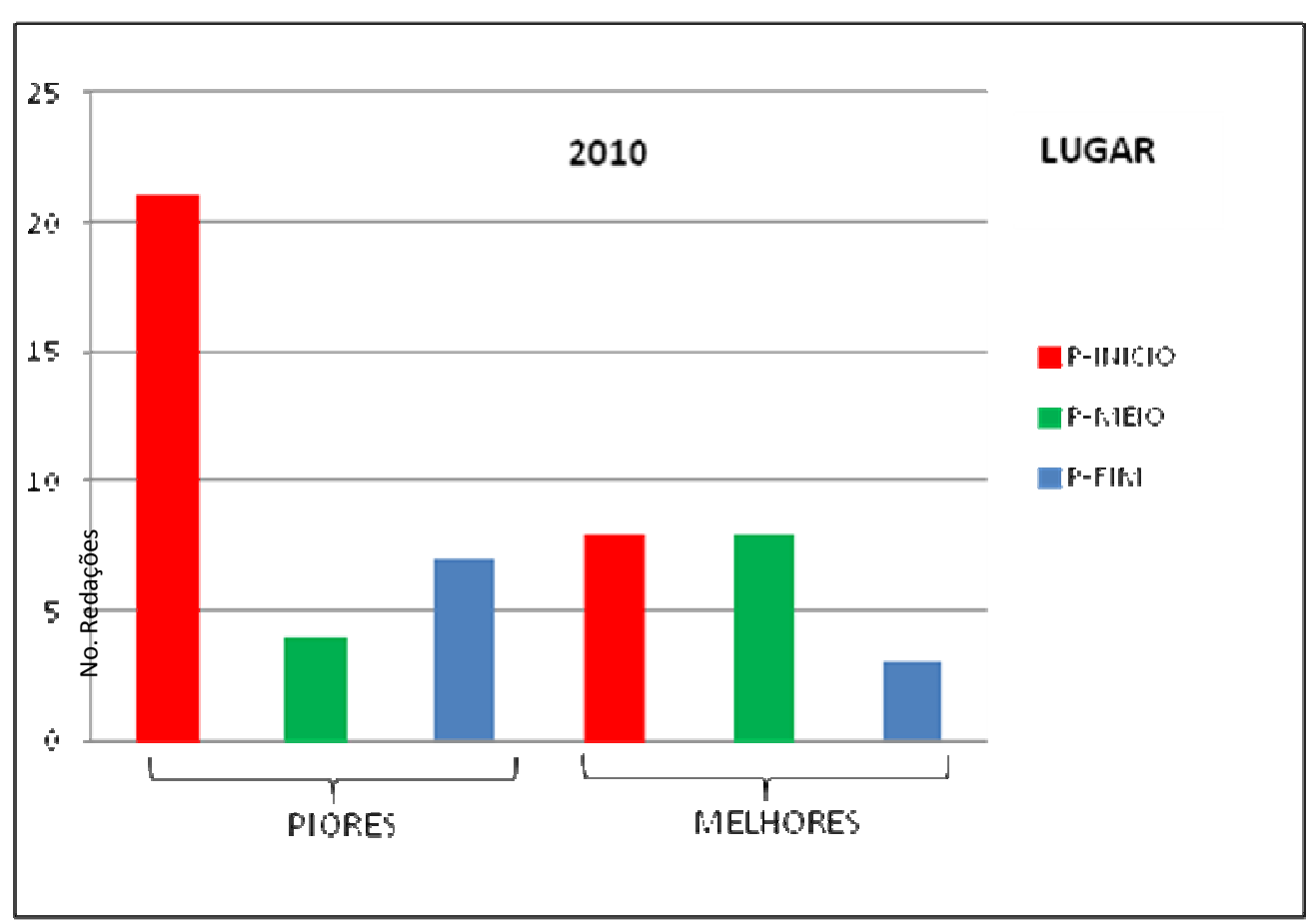

Gráfico 20: Ano 2010 - Expressões locativas topicalizadas e focalizadas 
Já para tempo e lugar juntos, foi possível ler no gráfico 21 que tivemos maior número de dados topicalizados nas piores redações. Quanto aos melhores textos apresentaram ocorrências apenas na posição medial e em número equativo às piores redações.

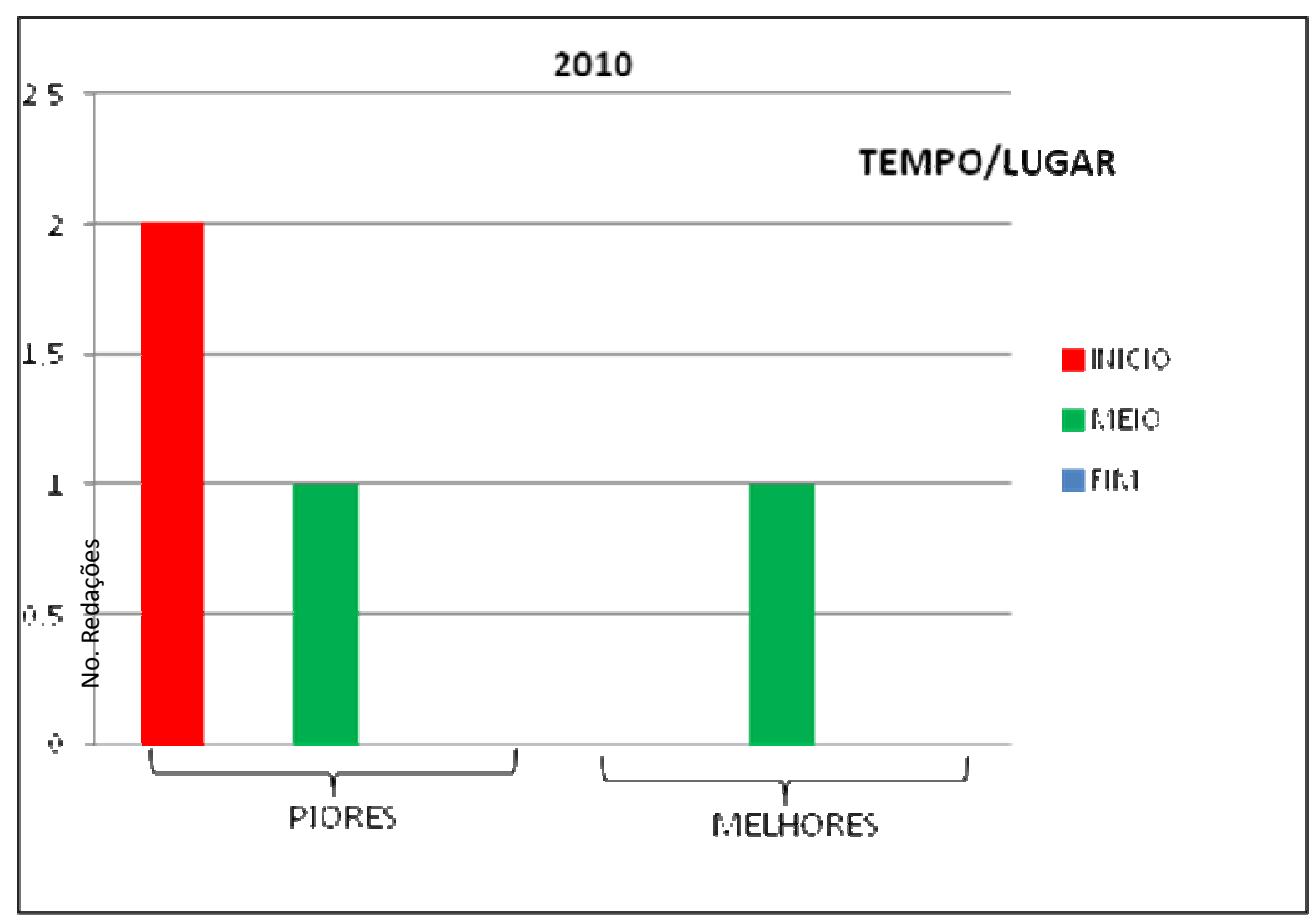

Gráfico 21: Ano 2010 - Expressões temporais e locativas topicalizadas e focalizadas

No ano de 2011, com quatro textos motivadores, discute-se a partir do sentimento de irmandade o amor ao próximo que ultrapassa o tempo e precisa marcar o seu lugar no mundo contemporâneo. Diante dessa temática, tempo (gráfico 22) e lugar (gráfico 23) apresentaram alto índice de ocorrências, inclusive na posição inicial do parágrafo, o que caracteriza a topicalização. 


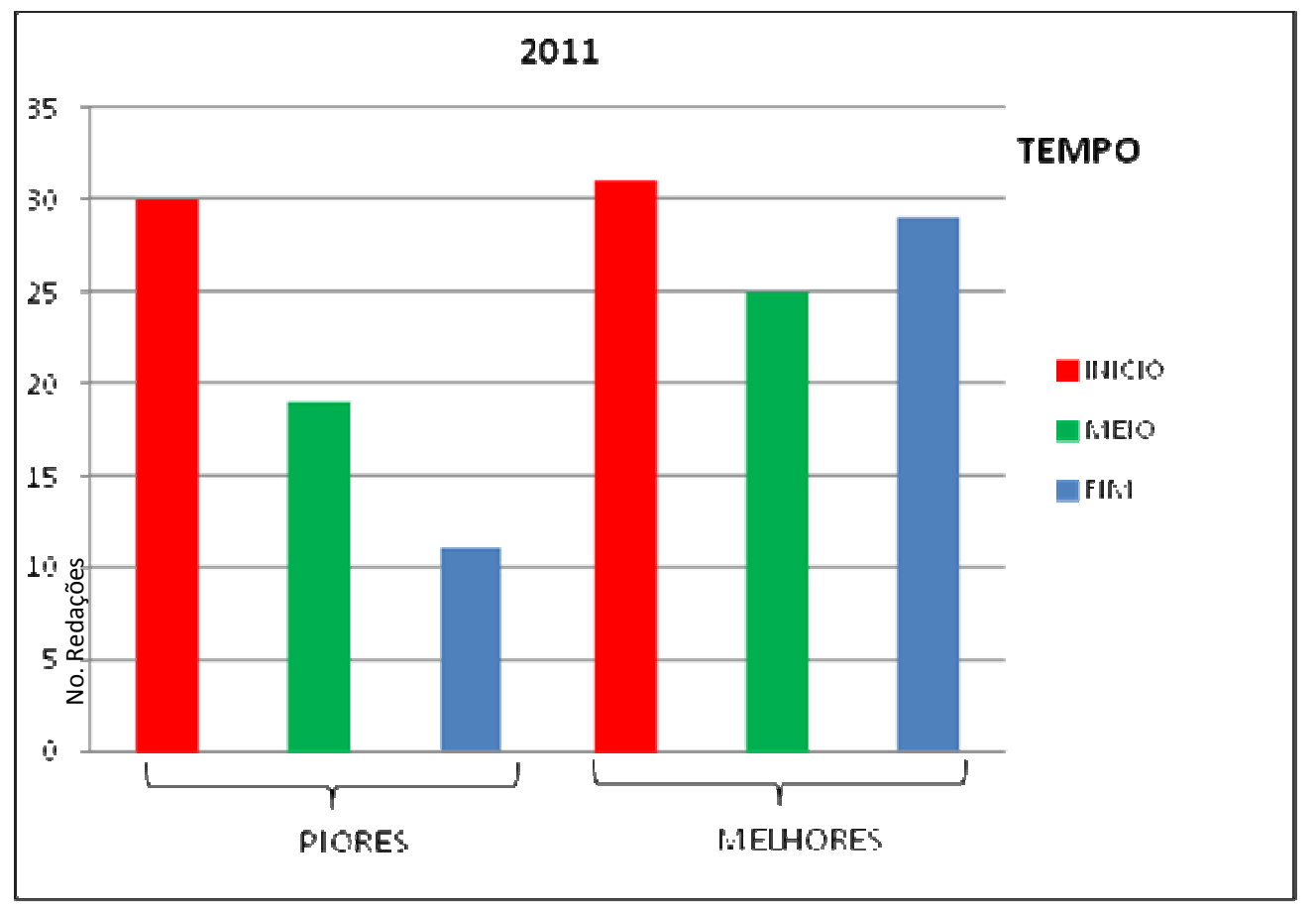

Gráfico 22: Ano 2011 - Expressões temporais topicalizadas e focalizadas

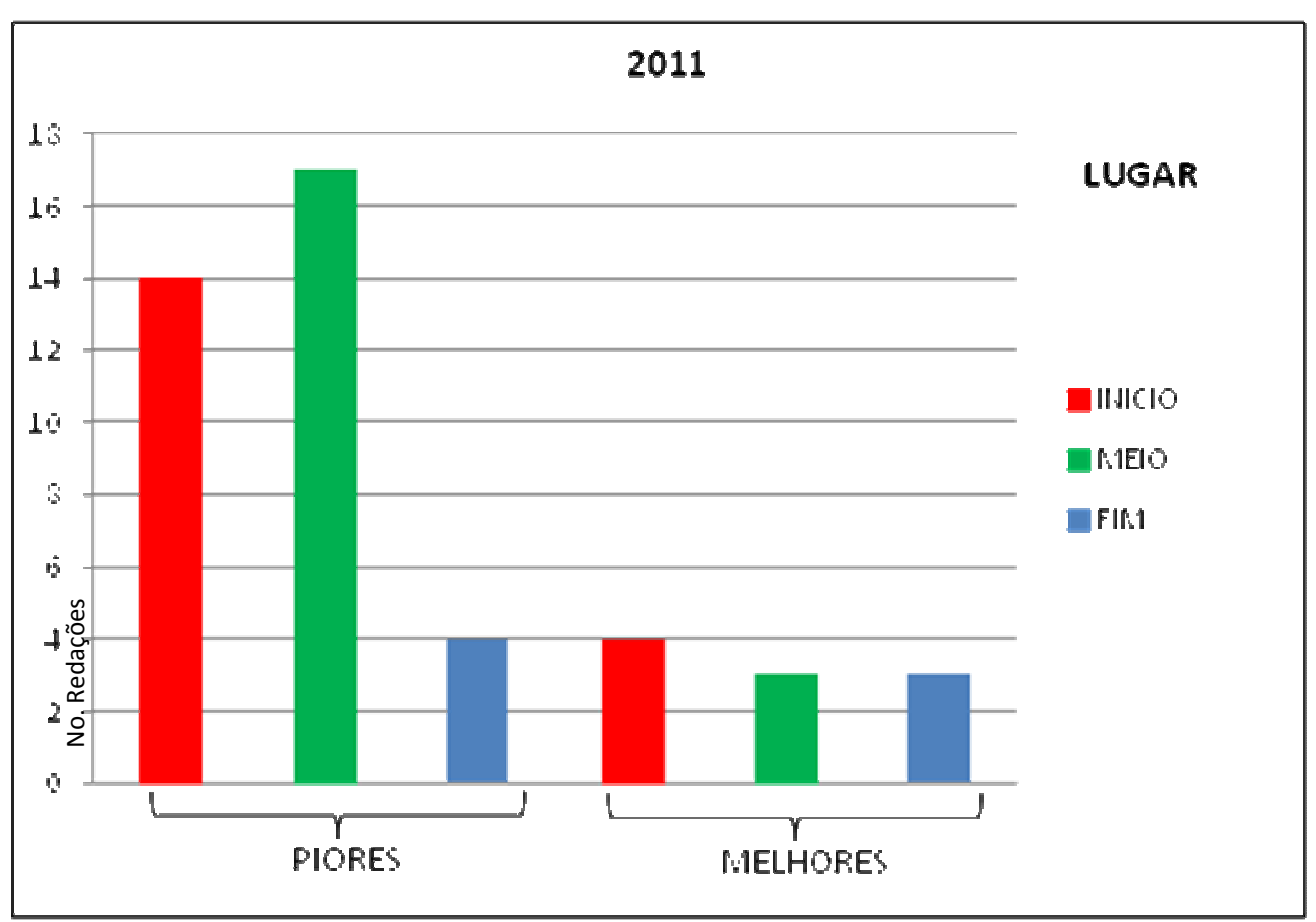

Gráfico 23: Ano 2011 - Expressões locativas topicalizadas e focalizadas 
Baseados na leitura do gráfico 24, ainda em 2011, tempo e lugar simultaneamente também apresentaram maior número de dados topicalizados. Algumas das expressões que ocorreram, nesse ano, foram "cenário social contemporâneo" e "sociedade atual".

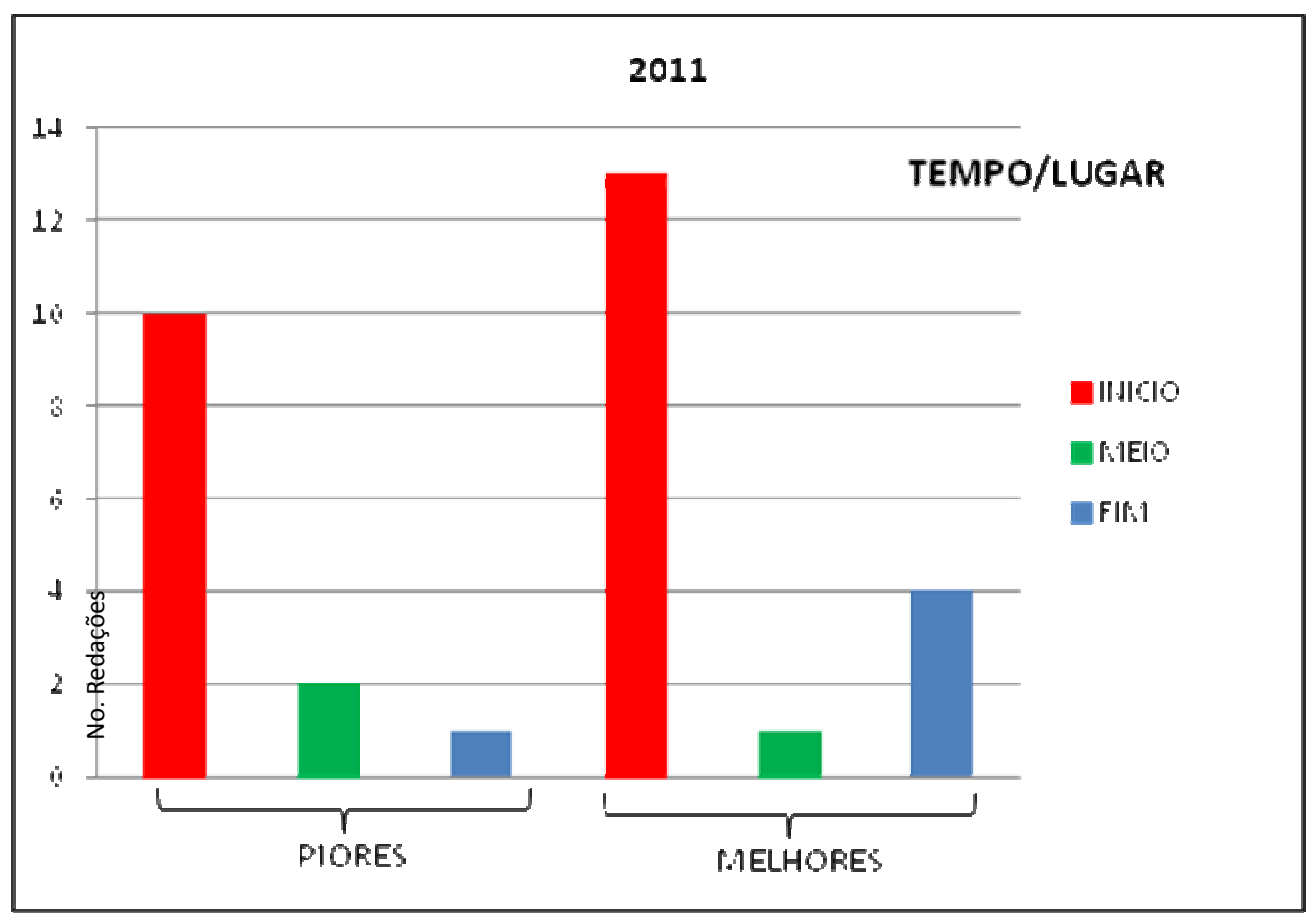

Gráfico 24: Ano 2011 - Expressões temporais e locativas topicalizadas e focalizadas

Ao observar os dados, vimos que tempo, lugar e tempo/lugar apareciam de forma recorrentes. Restava identificar uma razão para a oscilação observada durante a descrição dos resultados. Então, pensamos acerca do tema: teria ele alguma influência na escolha das categorias? Diante dessa pergunta, primeiramente revisitamos as amostras de redações e constatamos que tais categorias eram retomadas pelas expressões contextualizadas e não se tratava apenas de uma escolha lexical aleatória. 
Havia uma motivação para a escolha e esta poderia ser tratada em termos de sua complexidade, discernida pelas categorias cognitivas de lugar, de tempo e de espaço, três domínios dedicados à construção do espaço conjunto de atenção ou, na situação de texto, ao espaço de construção de tese, que foi organizado em padrões funcionais, conforme veremos na seção a seguir.

\subsection{Padrões de uso da categoria de espaço}

A separação entre melhores e piores, como já expusemos no capítulo sobre a metodologia de pesquisa desta tese, não atende a critérios próprios, mas a uma reprodução dos resultados de divulgação da própria FUVEST. Essa divisão, contudo, nos criou a curiosidade sobre a possibilidade de haver alguma relação entre self autobiográfico e complexidade linguística, já que até o momento chegamos a reconhecer essa estreita relação com índice de autoria.

Para tentar providenciar resposta suficiente para saciar essa curiosidade, recortamos da amostragem de dados somente aqueles que tinham como mote de tese a categoria de espaço. Descartamos, assim, desta análise, os primeiros parágrafos que tinham como categoria subjacente (ou como fundo) as categorias de tempo e lugar. A partir da amostra reestruturada - ou seja, a que toma somente a que contém a 
categoria de espaço -, organizamos os dados em termos de padrões funcionais ${ }^{35}$. 0 resultado foi o seguinte.

Padrão 1: Construção espacial de definição codificada por meio de construção equativa.

A conexão de duas orações com estrutura similar se dá por um predicador legítimo, um verbo de ligação. O sujeito oracional é um sintagma nominal genérico e abstrato, categorizado como sujeito atípico ${ }^{36}$. Isso ocorre no exemplo seguinte:

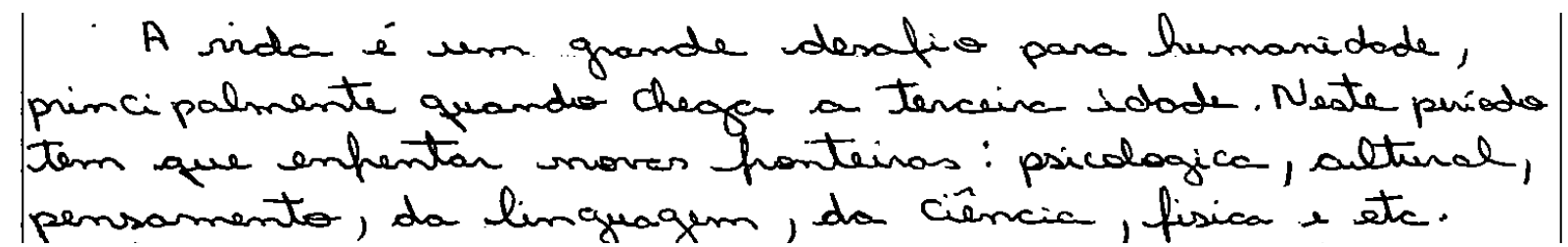

[(3) 500151 P2009 P6

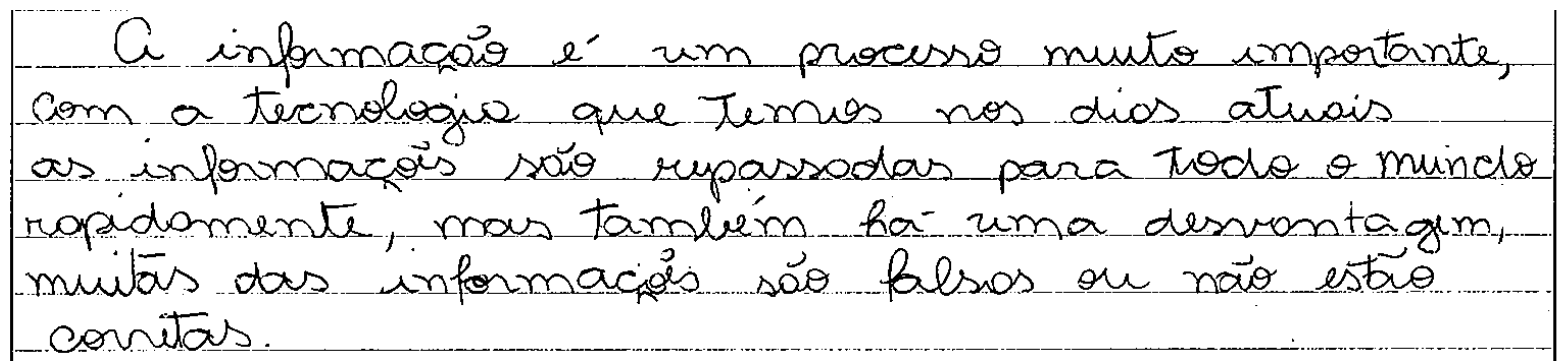

[(4) 500038 P2008 - 3]

\footnotetext{
${ }^{35}$ Lembramos que o critério que atende ao rótulo de 'padrão' diz respeito às similaridades construcionais (pareamento forma e função com significação espacial).

${ }^{36}$ O sujeito "vida", a despeito de ser topicalizado, não é exclusivamente humano não está associado à categoria "pessoa".
} 


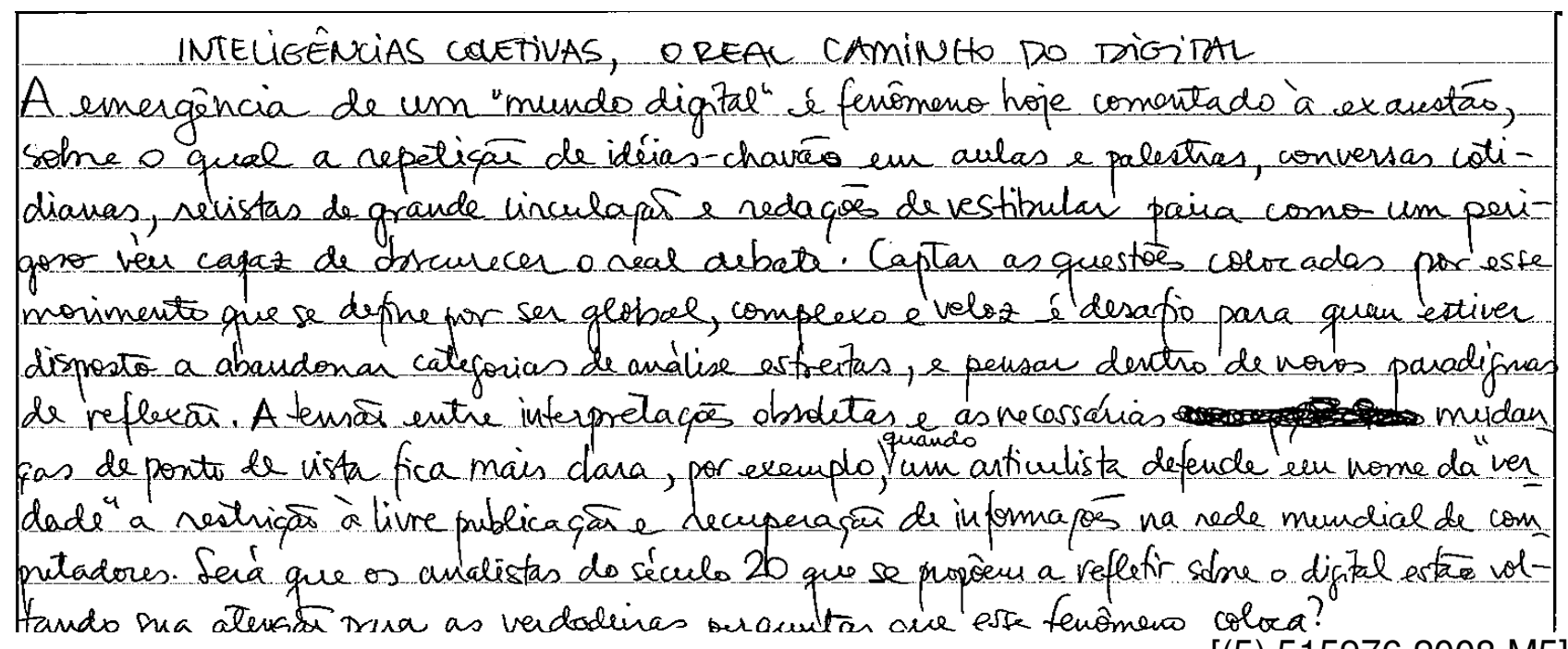
[(5) 5159762008 M5]

O exemplo (6) cria um espaço conceitual em que se objetivam estabelecer limites da abordagem temática, indicando o verdadeiro sentido da palavra-chave do tema. Por meio dessa estratégia discursiva na qual se fixa com precisão a tese do texto, invocam-se ações do self autobiográfico, que entrará em campo para situar o interlocutor (via clareza de exposição) e a banca examinadora (via marcas e índicios de autoria).

\footnotetext{
Dobre fues e retalloos de tempo

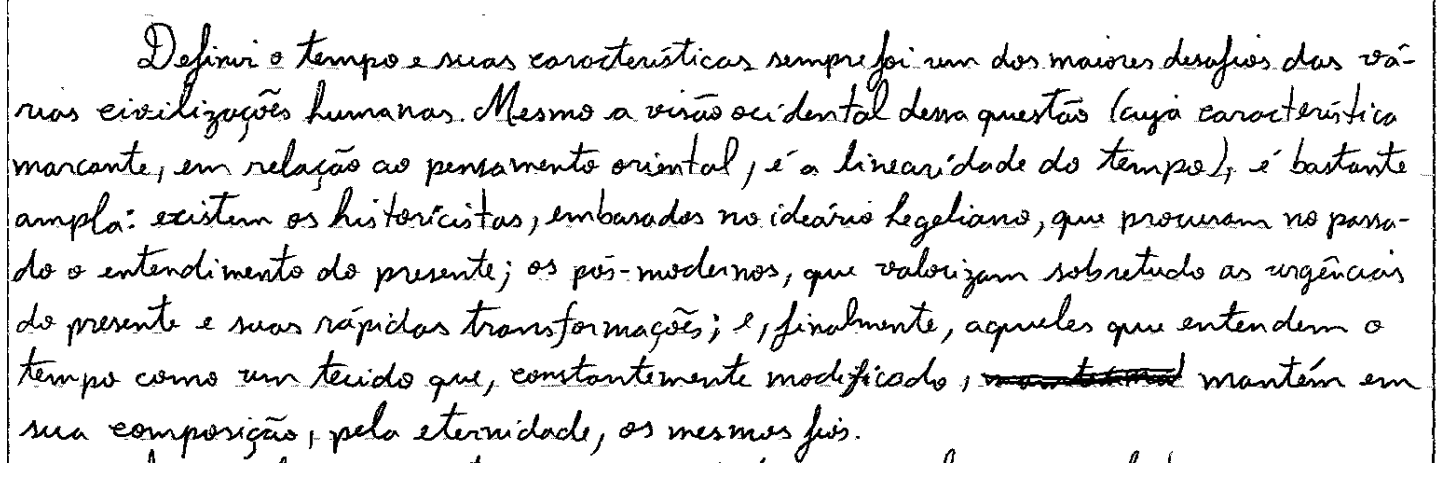

[(6) $5208502004 \mathrm{M} 11]$ 
Em cada um desses exemplos encontra-se um sintagma nominal à esquerda configurado como o ponto de partida para a construção equativa. Ocorre que a sentença mais à direita não mantém o exato paralelo sintático: o sintagma nominal à esquerda é definido pelo artigo e o que se encontra à direta é indefinido (exemplos 3, 4 e 6), seja pela presença de artigo indefinido seja pela ausência de artigo (exemplo 5).

O mesmo ocorre com o exemplo seguinte, que explicita um sujeito topicalizado, detendo, contudo, os traços típicos. Esse sujeito típico deriva de uma capacidade de articulação do self autobiográfico, constituindo-se por isso um espaço conjunto que requer maior abstração, porque é também maior a complexidade construcional exigida.

Padrão 2: Construção espacial consubstanciada pela presença de sujeito animado, humano, mais básico, porém mais específico,

Tal como ocorre no exemplo (7), um indivíduo supostamente ligado às ideias culturalmente circuláveis (no caso, Jacques Le Goff, um historiador francês especialista em Idade Média) demanda contribuições da bagagem discursivo-pragmática. Embora não seja exigida por professores ou mesmo pela banca da FUVEST, essa estratégia é positiva e pode impulsionar a avaliação da redação. Nesse sentido, a decisão do candidato é acertada e atende ao objetivo de demonstrar que está preparado para a vaga a que concorre. 


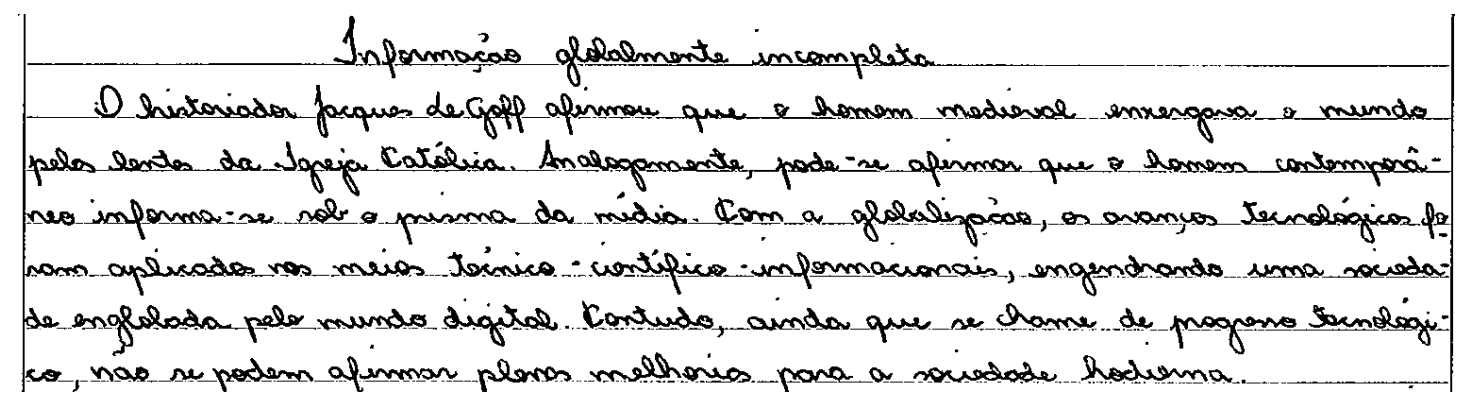

[(7) $5187112008 \mathrm{M} 1]$

Ainda no padrão 2 e já avaliando o exemplo (8), é possível explicitar um sujeito topicalizado de traços típicos (humano, animado) seja uma construção genérica. Esse sujeito típico deriva de uma capacidade de articulação do self central, tendo em vista a reprodução textual a partir de elementos mais próximos das experiências vivenciadas por supostamente todo indivíduo, construindo-se um espaço conjunto de senso comum. Lembremo-nos de que o senso comum demanda menor complexidade, o que requer material linguístico conformado em menor abstratização também.

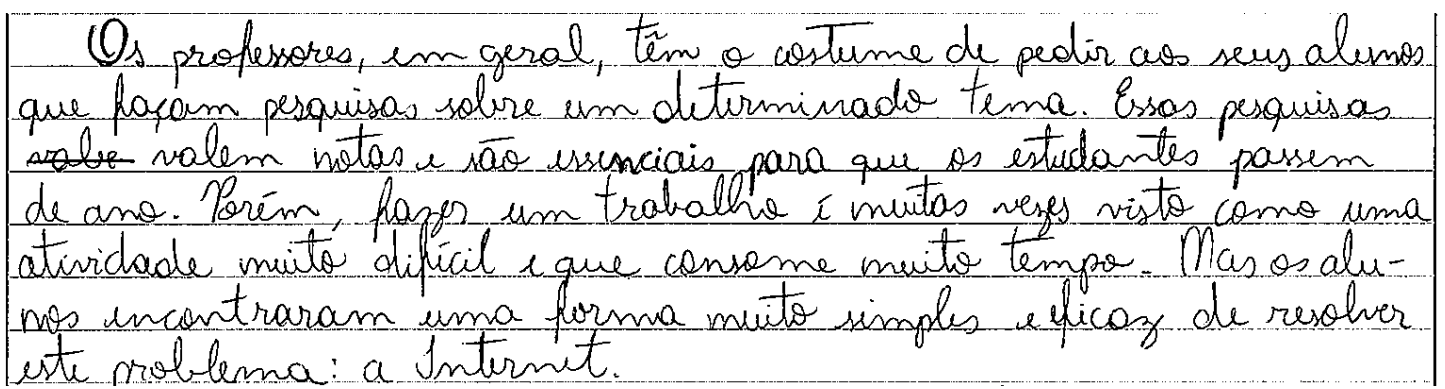

[(8) 5038612008 P77] 
Padrão 3: Espaço topicalizado concretizado por uma expressão circunstancial de caráter genérico, que, num modelo funcionalista, atua como satélite da sentença.

Torna-se relevante esclarecer que é um padrão recorrente uma preposição locativa encabeçando o conteúdo circunstancial, o que reforça a ideia de espaço como uma categoria derivada e mais complexa. Ressaltamos também que, apesar de a categoria ser mais abstrata para a interação, ainda assim, ela também denota uma gradação informativa e, consequentemente, linguística. Sendo assim, uma construção circunstancial como a do exemplo (9)"no mundo atual", não demanda conhecimento específico para a compreensão da mensagem. Essa construção demanda self central em ação, por isso ela é mais recorrente e topicalizada. Ela situa, sem prever qualquer barreira gerada por diferenças de bagagem discursivo-pragmática.

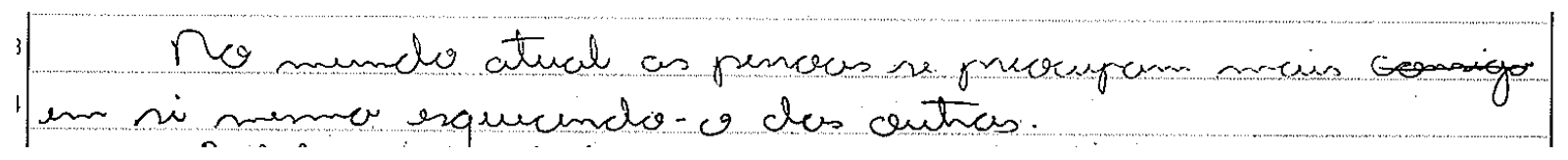

[(9) $1000692011 \mathrm{P} 2]$

O exemplo (10), em comparação com o exemplo anterior (9), permite-nos demonstrar que "mundo contemporâneo" exige maior conhecimento contextual. Dessa forma, maior complexidade linguística também será prevista nessa conjunção de espaços porque a demanda original requereu operações mais complexas por parte da mente humana (a de recuperar um tempo referido no texto, o qual não é pontual, mas depende de outras construções semânticas contidas nesse mesmo texto). 


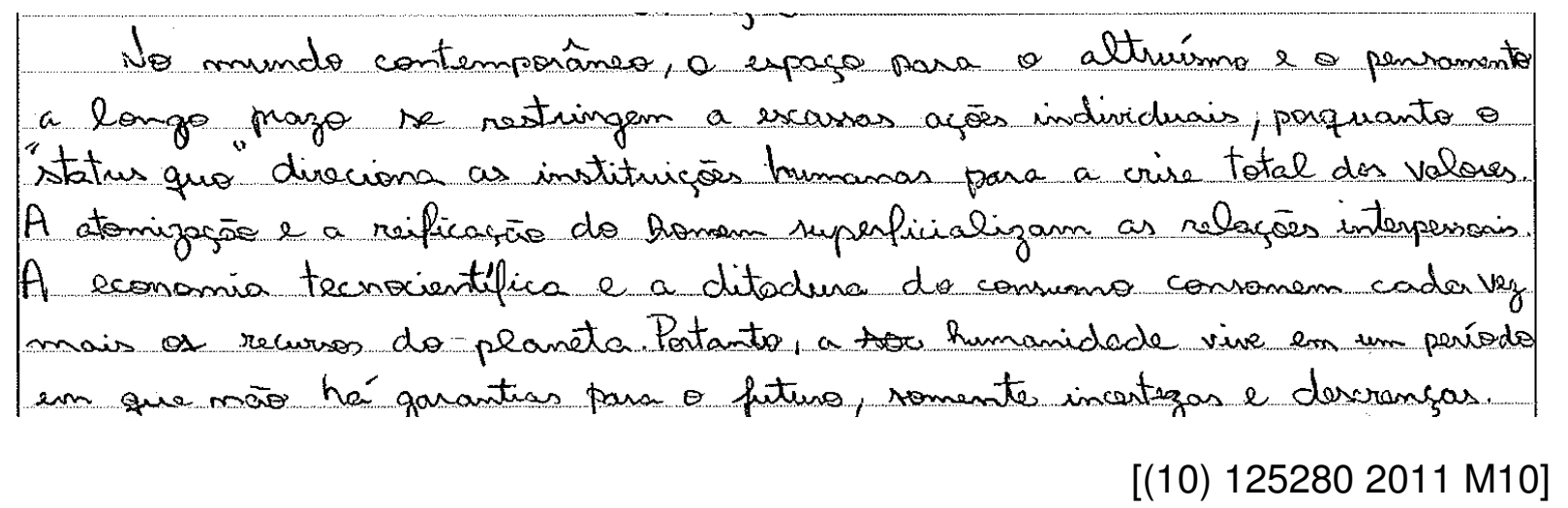

Ainda no padrão 3, o exemplo de número 11 caracteriza-se por conter topicalizado um espaço mais genérico, que, na sequência, é restringido semanticamente por outras informações inseridas numa oração relativa. Essa construção é, assim, mais complexa, pois existe uma oração relativa logo depois do termo circustancial "num mundo", especificando e recortando melhor o espaço desse mundo. Por isso, entendemos que o espaço cognitivamente mias complexo reproduzse na língua também em uma estrutura mais complexa [SN + oração relativa = onde vemos a diversiade de profissões e a desmistificação do conhecimento]. 
O exemplo a seguir (12) demanda similarmente maior complexidade linguística, pois envolve tempo + lugar. Por outro lado, não exige esforço cognitivo demasiado, pois há grande bagagem informativa pressupostamente compartilhada, já que quem está lendo deve ter nascido antes de 1990 e deve ter vivenciado o fato relatado ou saber dele. Ainda assim, o candidato que constrói o texto o faz situando o leitor em uma sequência de períodos que contextualizam o momento histórico.

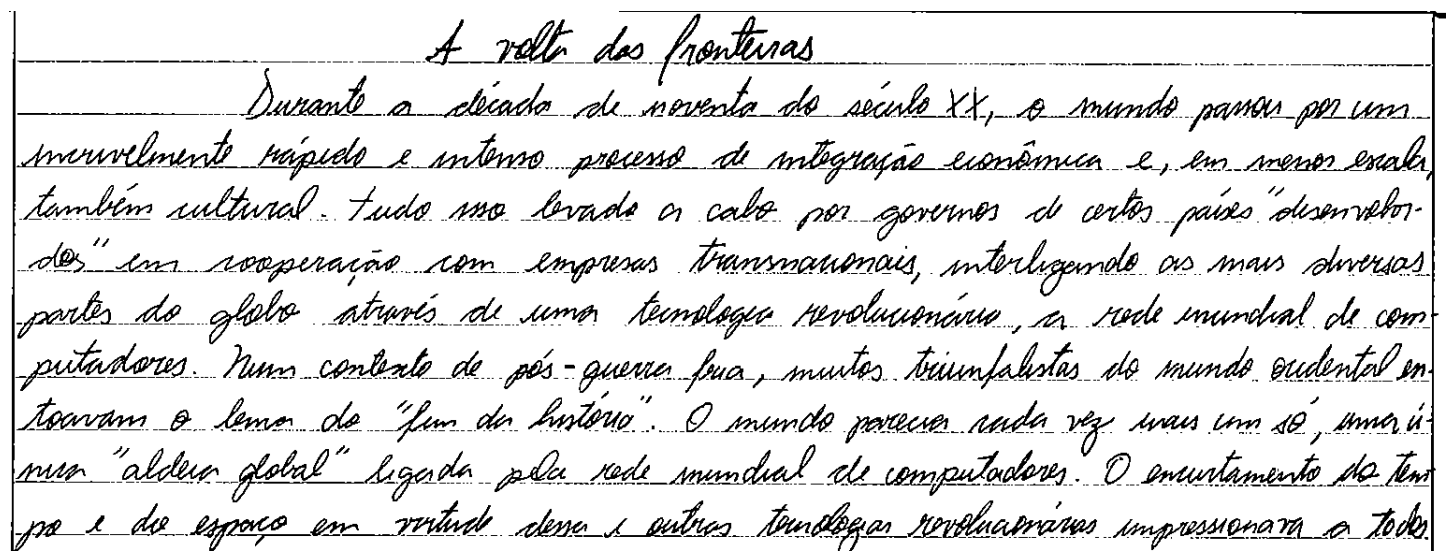

[(12) 5176482009 M3] 
Padrão 4: Espaço topicalizado avaliativo em que o candidato constrói um espaço de atenção conjunta específico e localizado.

Trata-se de reflexo de uma evocação do self central, que conjectura sobre uma determinada imagem-espacial, para a qual elabora um relato circunstanciado ou enumerativo. Este padrão é demonstrado no exemplo (13), para cuja compreensão é exigido maior conhecimento sobre o domínio geográfico relacionado. Utilizando construções linguísticas aparentemente soltas e desconexas, mas localizadoras, o candidato conduz o leitor a criar uma imagem geográfica que, na produção textual, se manifesta como um plano de fundo para o leitor.

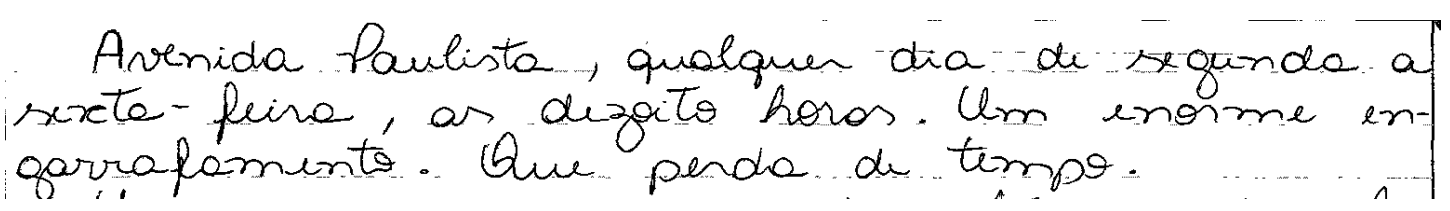

[(13) 5030042004 P21]

O exemplo a seguir (14) igualmente vincula-se ao padrão avaliativo. A partir de uma sequência de afirmações, o autor elabora uma construção de sentido mais complexo com o objetivo de contextualizar. Dessa forma, o parágrafo contém uma tese resultante da ação de um self autobiográfico. 


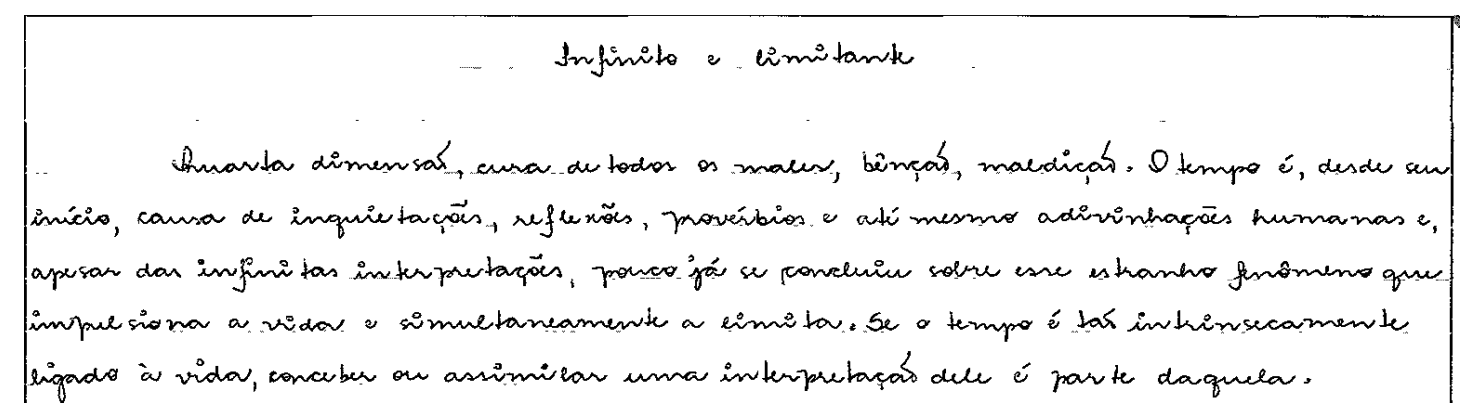

[(14) 5092702004 M100]

No exemplo (15), a seguir, há uma tentativa de se definir adequadamente a palavra "sociedade", separada por dois pontos e seguida de um "possível" aposto, com avaliação pouco complexa. Nesse caso, o espaço é construído por um self central em maturação.. Portanto, o autor se esforça em construir um espaço-conceitual, porém ainda sem uma contribuição cultural concreta, pois a sequência de afirmativas não estabelece uma relação de sentido perfeitamente guiada pelo escrevente, e isso impede a elaboração de um conceito adequado e preciso por parte do leitor.

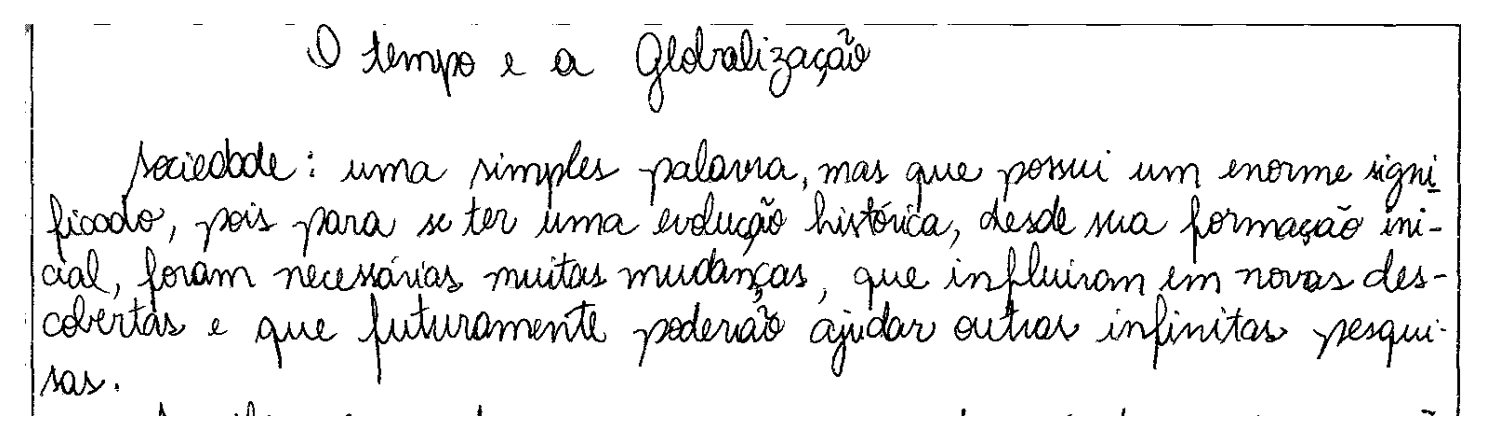

[(15) 5176252004 P45] 
Padrão 5: Espaço de reflexão, em que o candidato, sintaticamente, recorre a sujeitos compostos inseridos em uma estrutura afirmativa.

Seu objetivo é elaborar a tese a partir de uma constatação. No entanto, a constatação não se realiza adequadamente, caracterizando uma produção textual em que o self central age em seu nível mais básico, provocando, em muitos casos, uma inconsistência ou incoerência.

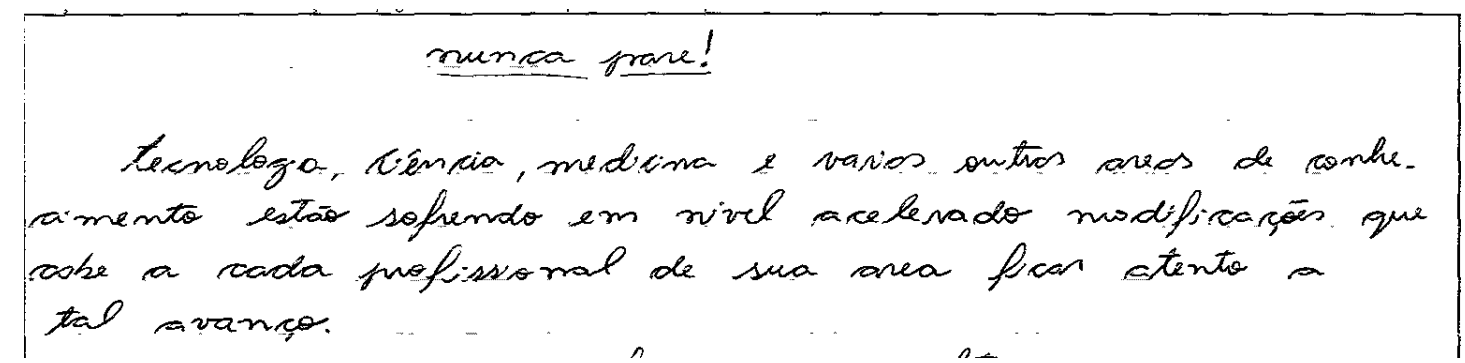

[(16) 5226242004 P64]

Enquadra-se nesse mesmo padrão o exemplo (17), cuja construção, num padrão sintático apresentacional, não apresenta sujeito, mas aponta para o sequenciamento de um fato consumado de existência, facilmente constatável por quem lê. Trata-se de uma estrutura que foge ao padrão SVC, refletindo o resultado de um self central que se pretende, conscientemente, mais autobiográfico. Falta-Ihe, contudo, bagagem cultural para arriscar-se mais na escrita.

\footnotetext{
a concepção de tempo e a humanidade

Há duas grandes concepcōes de tempo que englobam outras: a concepcōo cíclíca, defensona da repetiças de fatos históricos atraves do tempo, e a concepcão linear, defensora de uma linha reta do tempo, onde a passado não se repetirá no futurol.
} 
[(17) $5003132004 \mathrm{M} 80]$

Padrão 6: $\underline{\text { O espaço intertextual caracteriza-se pela influência de informações que }}$ foram associadas pelo escrevente.

Sendo assim, ele recorre a sua memória identificando relações subjetivas entre o tema e a contribuição da memória. Em termos de língua concretamente apresentada em forma de texto, o que se vê é ação de um texto sobre outro, que se torna modelo ou ponto de partida para a discussão que se desenvolverá. Com essa estratégia, retomam-se textos que abrangem a grande massa social, como é o caso do hino nacional ou, mesmo, partes dos textos motivadores.

No exemplo (18) a tese elaborada é abstrata, mas contém em sua base a informação culturalmente compartilhada topicalizada. Assim como há uma decisão de um escrevente (subjetividade), há também a intenção clara de interagir e se fazer entender a partir da construção de um espaço conjunto de atenção (intersubjetividade). Tal subjetividade lida com valores sociais compartilhados, via utilização de frase feita, lugar comum ou reprodução aparentemente descontextualizada daquilo que já de conhecimento do leitor. Esse padrão de elaboração remete a uma orientação do self central. 


$$
\begin{gathered}
\text { Concerto músical } \\
\text { Patria anada, idalatiada, de que modo? A travén do } \\
\text { tempo e da bistóvia que se preenche num passodo, pre- } \\
\text { sente a futuro. }
\end{gathered}
$$

[(18) 5221032004 P57]

Em um nível mais baixo de elaboração, fruto do protosself, está a tentativade de um escrevente que não domina a modalidade de escrita, em suas propriedades, tais como a autonomia contextual. O exemplo (19) ilustra esse caso, em que o escrevente transfere para o papel o que aparenta ser uma desorganização do tipo de texto, acrescida de uma pressuposição de leitura, indesejável para a autonomia da dissertação vestibular. O escrevente não domina nem conteúdo nem forma, e o espaço seguro para a construção da tese é a ação do outro, tal como numa interação face a face. O autor dessa tese constrói o espaço por meio do que a própria proposta disponibiliza, imaginando que o leitor a conheça. Nesse sentido, busca uma forma inadequada para uma construção desconhecida (a dissertação argumentativa). Há, assim, um alinhamento entre forma e conteúdo, tal como prevê o princípio da iconicidade.

- Texto II passa a idéia de que passado e futuro NÃO INTERFEREM NO PRESENTE, E QUE NÃO EXISTE PASSADO OU FUTURO, APENAS O AGORA. 
O espaço intertextual, no exemplo (20), é produzido em alto grau de informatividade, haja vista que o escrevente apresenta uma epígrafe para reforçar o espaço da tese elaborada e constrói um diálogo com outros textos no parágrafo introdutório. Tal espaço é construído no espaço do sujeito (um lugar à esquerda na sentença) por meio de uma citação.

Essa forma de produzir espaço é altamente dependente da bagagem discursivopragmática do escrevente, que é detentor de todo o conhecimento, mas não o faz sem que comunique com algumas pistas (aspas, deslocamento, nome de autor) ao seu interlocutor-leitor. A construção dessas pistas também é intencional, em estado de vigília. Aqui, há a clara intenção de evidenciar que detém o saber. É o self autobiográfico em ação, mobilizado para conseguir o objetivo: a nota alta no vestibular. 


\section{Do Mito do tempo e do tempo do Mito}

"ó fildogos, a vido é bieve...

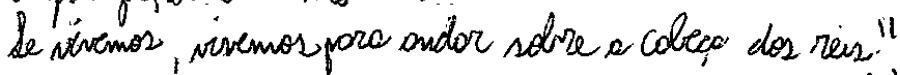

W. Shohespeare "Hewrique II

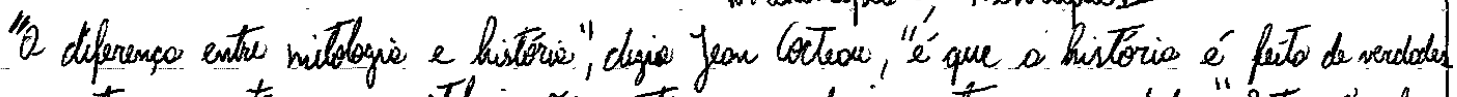

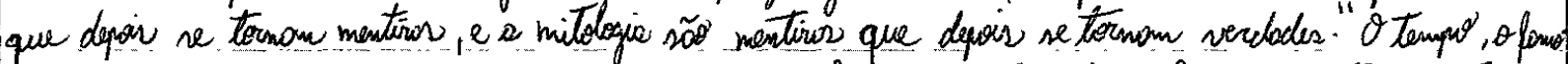

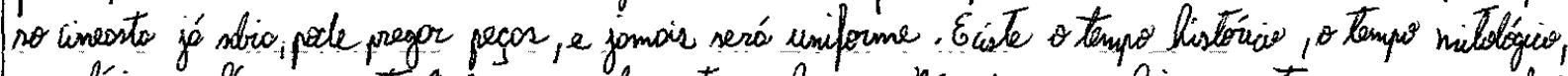

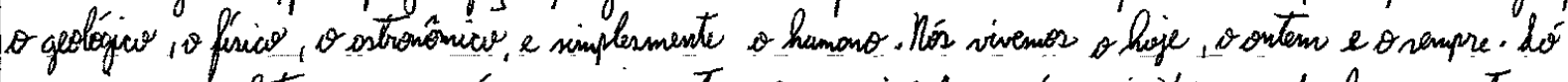

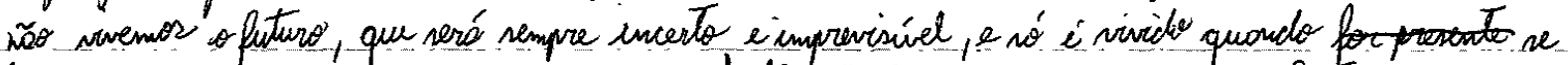

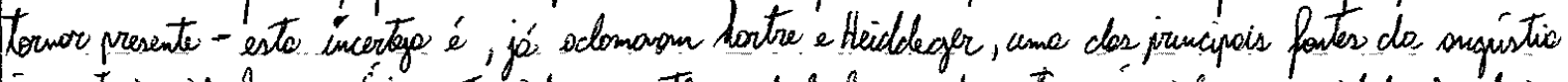

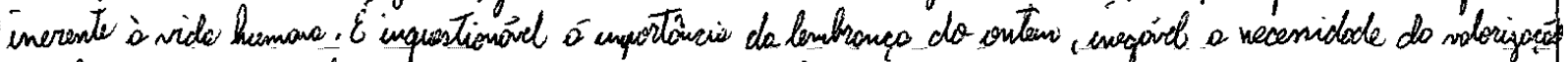

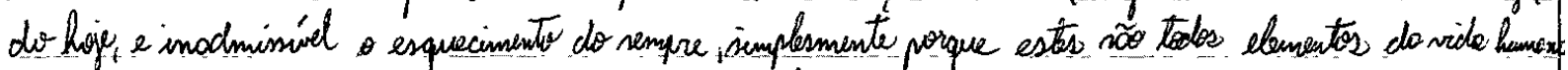

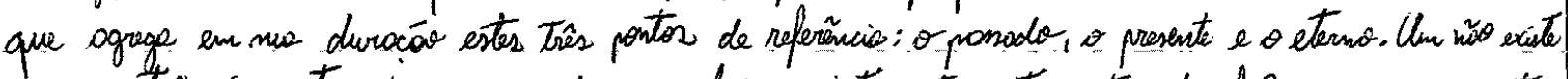

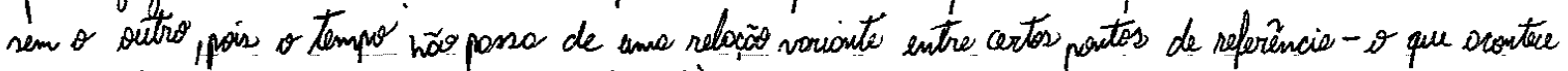

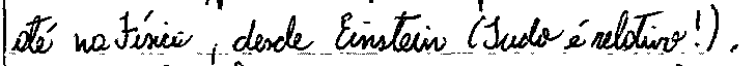

[(20) 5120572004 M15]

Padrão 7: O espaço da dúvida é elaborado a partir de um espaço conjunto que elimina a responsabilidade de uma afirmação incerta feita pelo autor do texto.

Quanto mais ela direcionar o leitor a acompanhar a reflexão do escrevente, tanto mais informações serão apresentadas. Desse modo, há a invocação do self autobiográfico para melhor explicar a tese. Percebemos isso no exemplo sequencial (21). 


$$
\text { O) tempo de code un, cada un a sen tempo. }
$$

Tabrez una dos maires conquistas da humanidade em sera evolugeos dos covernas à pociedade moderma seja o conceito de tempo. Con a idéia de passagen do tempo está a ideia de evolução, de mudança, de expecta tiveo que viño, de lembrancas do que já veio. A conceppés de tempo nos diferencia. dos demais elementos da natureza - animais, vegetais, seres inanimados em geral, trodos estes vivem em un cotidian a temporal, perene, interrompido a penas com a morte (para os seresvivss) e a destruiçä. O'homem conscien te do tempo é consciente de pua mortalidade, de pua condiẽ̃o efímera, talvez por isso busque a cada momento modifica $\theta$ mundo que o sodeia $e$ interagir com seus componentes. Talvez peja s própsis tempo que nos far ver
dodeiramente humaros.

[(21) $5179162004 \mathrm{M} 12]$

No e exemplo seguinte, o espaço da dúvida é elaborado a partir de estruturas como "eu acho", apresentando parco repertório para explanação da tese e limitando-se ao conhecimento que está presente no cotidiano. Trata-se de um modalizador, para não assumir uma posição categórica, do detentor da verdade, possivelmente pela falta de repertório para a construção da tese.

Por isso, o uso de um modalizador encabeçando a opinião produz uma impressão de tese fraca e altamente subjetiva. O espaço é colocado em segundo plano, porque o autor preferiu colocar a dúvida como informação mais proeminente em sua própria tese. É uma produção típica de um self central. Vejamos o exemplo a seguir: 


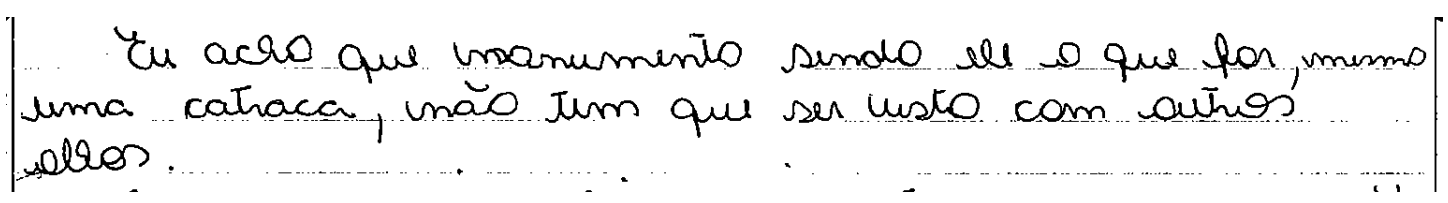

[(22) 509780 2005P53]

Se compararmos os dois últimos exemplos, observaremos que a palavra "talvez" é uma variante da expressão "eu acho". Entendemos que "talvez" foi usado para que ou autor não fosse tão categórico, embora estivesse certo da tese que construiria ao longo do parágrafo. Na verdade, o termo circunstancial de dúvida foi utilizado apenas para que não fosse tão impositivo, que merecesse o crédito da incerteza. Nessas circunstâncias, é comum que o candidato faça uso de um "eufemismo" para sutilmente persuadir o leitor de que sua tese, própria de um self autobiográfico, é plenamente satisfatória.

A despeito dos padrões cognitivos identificados, percebemos que, em cada um deles, é possível identificar a maturação cognitiva escalar do escrevente nessa tarefa de elaborar um texto dissertativo-argumentativo. Os dados que revelaram alto grau de maturação, equivalem, com correlação linguística em termos de complexidade, às soluções de um self autobiográfico (DAMÁSIO, 2011) ou, seja, a um acoplamento estrutural interpessoal (MATURANA e VARELA, 2001).

Nesse sentido, poderíamos distinguir entre estratégias mais básicas e estratégias mais complexas, e isso alteraria, em grande medida, a distribuição dos dois conjuntos da FUVEST (as melhores e as piores redações). 
As mais básicas e menos adequadas redações são as que denunciam o nãodomínio da forma. Já, as menos complexas constroem o primeiro parágrafo num nível de self central, isto é, retomam estratégias já conhecidas e treinadas fartamente na escola para lidar com a novidade do tema. Vejamos a seguir:

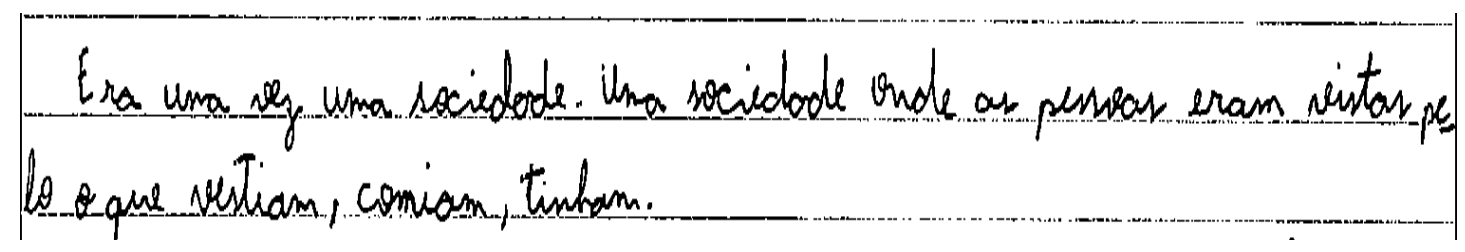

[(23) 1028852010 P54]

Nesse exemplo (23), o candidato constrói o espaço conjunto de atenção por meio de uma construção que funciona como alegoria que revebera um plano textual irrealis, o mundo do faz de conta, o mundo infantil. Portanto, o parágrafo introdutório se desloca para o plano da irrealidade, não atendendo a uma elaboração de tese e a um posicionamento baseado em fatos reais, conforme é solicitado pela FUVEST.

A solução do escrevente, nesse caso, é o preenchimento do 'espaço' da tese por elementos superficiais que estão baseados no senso comum. Essa características permite reconhecer a imaturidade cognitiva a serviço do texto, resultando em uma produção típica do estágio do protosself.

Diferentemente daquelas, as redações com estratégias mais complexas, como o exemplo (24), 


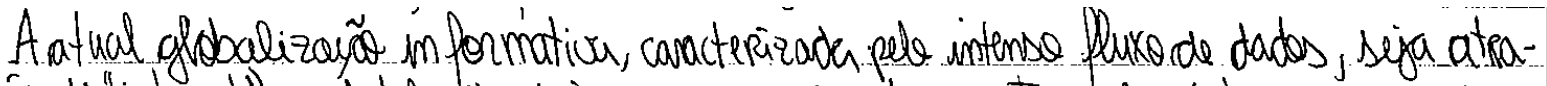

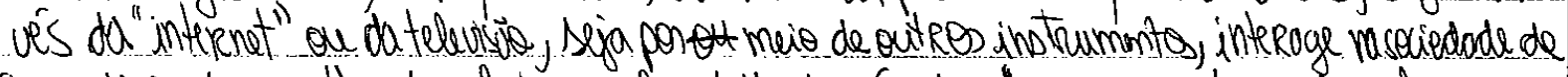

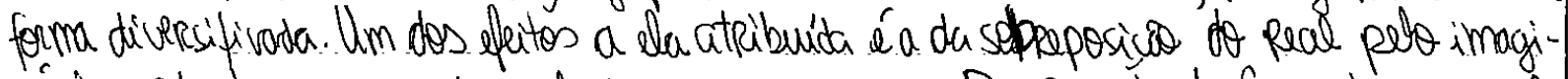

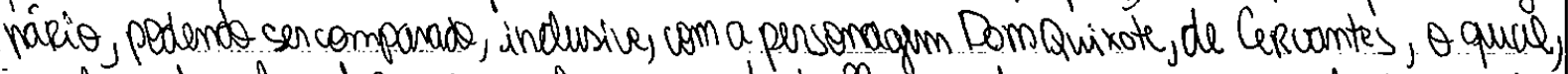

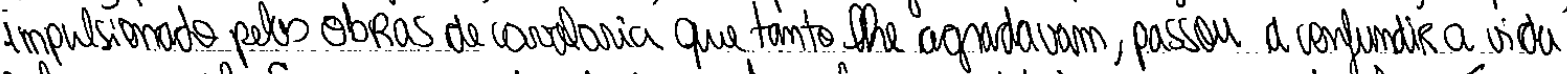

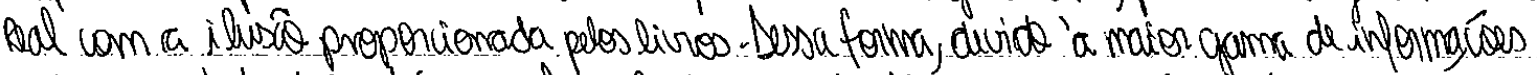

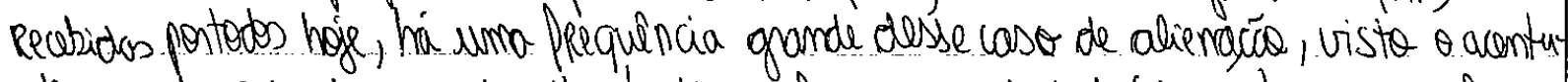

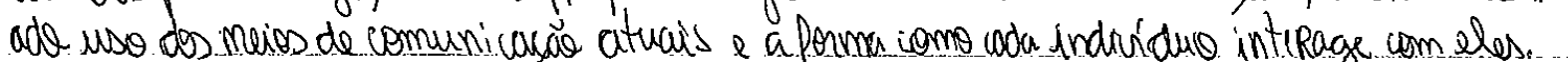

[(24) 1109972010 M26)

são típicas de um self em estágio mais adiantado. Nele, verificamos que o espaço da tese é ocupado por um sujeito típico (agente, tema, tópico, humano e animado). Este é pressuposto como informação compartilhada, daí a primeira posição na sentença. Para dar essa impressão de conhecimento compartilhado, o escrevente forja com outras informações, inclusive com uma oração adjetiva [que é caracterizada pelo intenso fluxo de dados, seja... seja...] requerendo do leitor uma contribuição compreensiva.

Exemplos como (20) e (21), já mostrados nos padrões anteriores, apresentam contextos científicos que extrapolam a visão empírica. Preocupam-se com os efeitos, mas principalmente com as causas e leis que podem dar sustentação à tese a ser defendida. Mais do que isso, manifestam uma preocupação com a seleção que mais adequamente beneficiará a tese na perspectiva do avaliador da banca examinadora.

Nesse âmbito, constrói-se uma ordem lógica que possibilita a formação de ideias voltadas à pesquisa, ratificadas muitas vezes por especialistas citados na própria introdução de seus textos. Ainda nesses textos, com características mais filosóficas, não raro observamos hipóteses postuladas como respostas às questões formuladas, 
com o fito de direcionar o interlocutor ao ponto de vista defendido no corpo do texto. Configura-se, nesse uso, a mobilização da categoria cognitiva de espaço em sua materialização mais abstrata.

Essa é uma caracterização da maturidade cognitiva a serviço do texto, produzida pelo self autobiográfico. Nos exemplos (15) e (16), embora seja categorizado o espaço, não se apresentam no mesmo nível de complexidade dos exemplos (20) e (21), pois constatamos ali frutos de um self central, objetivamente treinado para cumprir a missão de elaborar uma tese.

Já, os exemplos (19) e (22), encontra-se um espaço, que não encontra amparo no repertório cultural do escrevente, combinado ao não domínio da tipologia textual. Não se encerra aí no entanto essa lacuna observada: se o escrevente não detém a forma disponível, tampouco compreende como organizar o conteúdo, é certo que não terá à sua disposição as complexidades linguísticas disponíveis. Assim, outros aspectos observados na análise dos padrões, que são resultados de um protosself, podem aproximá-lo da modalidade falada, em que a pressuposição é forte. Observemos o continuum a seguir:

$$
\begin{aligned}
& \text { - Complexo ..... }>\ldots . . .>\ldots>\ldots \ldots . . \ldots \ldots . . \ldots \ldots+\text { Complexo } \\
& \text { (19) (22) } \\
& \text { (15) (15) } \\
& \text { (20) (21) }
\end{aligned}
$$

Continuum 3: Avaliação de exemplos dos padrões no continuum de complexidade 
Agora que já descrevemos os padrões num continuum baseado na complexidade gradiente, é importante reconhecê-los, baseados na proposta de Damásio (2011). Para isso, retomemos como base os estágios da mente, esquematizados no quadro a seguir:

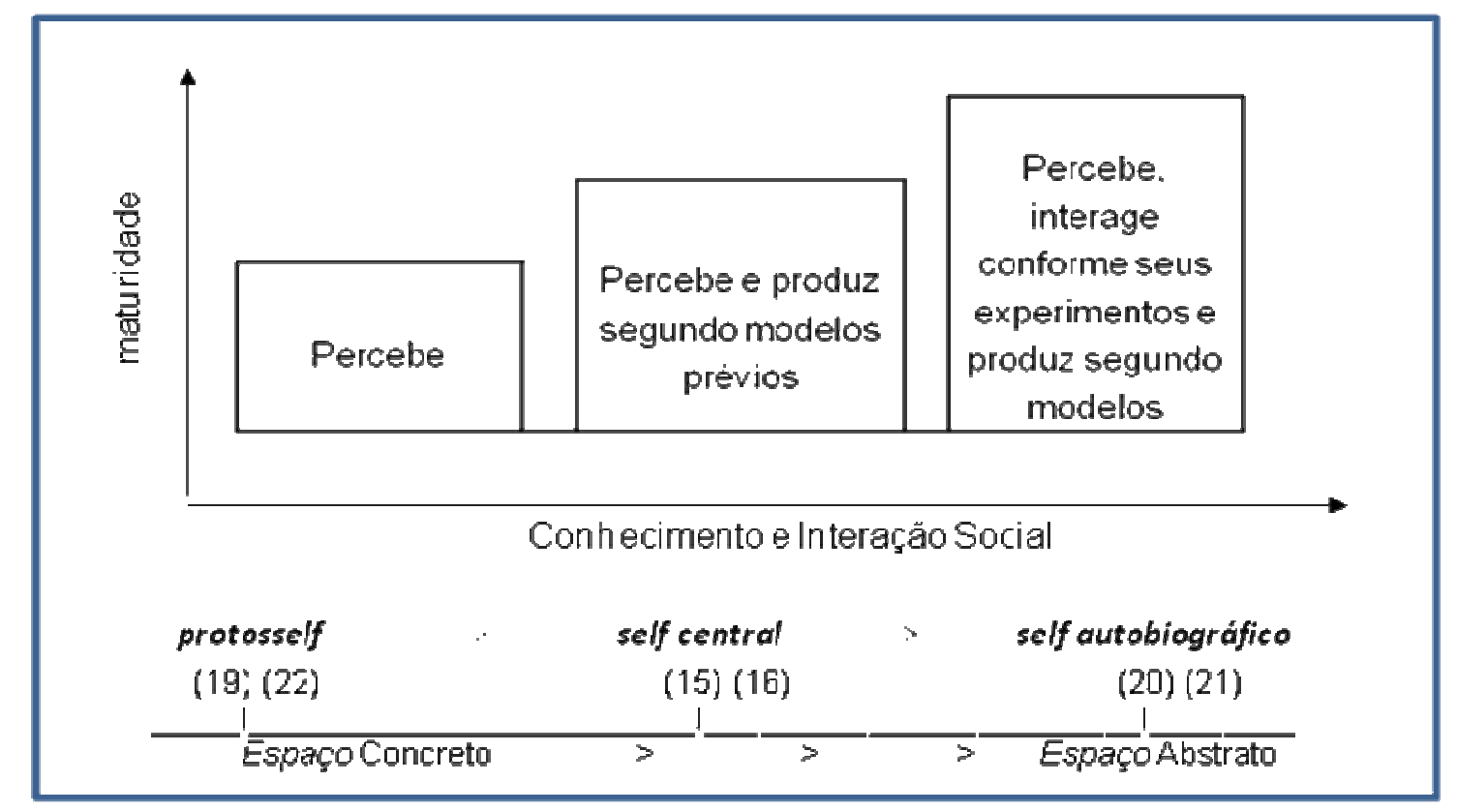

Quadro 13: Gradação da complexidade espacial

Os exemplos (19) e (22), considerando o continuum de uma mesma categoria, neste caso a de espaço, situa-se em um grau de menor abstratização, comparando-os aos blocos gradativos de exemplos (15), (16) e (20), (21).. Sendo assim, um indivíduo que percebe e interage, conforme seus experienciamentos, é capaz de produzir um texto dissertativo. Até onde podemos perceber, a diferença de resultado reside numa gradação da complexidade formal de conhecimentos mobilizados na escrita para a interação social, o que o torna candidato adequado para ter tido acesso a informações 
culturais diversas. Em consequência, também será um bom candidato a realizar a transposição de repertório pessoal para o texto.

Nos capítulos iniciais desta tese, perguntamo-nos se intenções textuais poderiam ser codificadas sintaticamente. Ao que tudo indica, pelo menos com relação à elaboração de tese, sim. Isso se explica pelo fato de o parágrafo introdutório propiciar a topicalização, recorrente de planos de fundo para o que se argumentará. Sendo assim, as categorias de lugar, de tempo e de espaço serão as candidatas ideais, ainda que a depender da complexidade adquirida, vivenciada e mobilizada pelo escrevente. ,

Essa foi a razão pela qual, posteriormente, perguntamo-nos sobre o motivo de o cérebro humano resolver assim a construção do primeiro parágrafo. E a resposta foi conhecida com a análise das teses elaboradas e das estratégias mobilizadas para isso.

Como a categorização cognitiva não se desenvolve nem se materializa com categorias atômicas, mas fluidas, é esperado que sentidos e formas se conjuguem em termos de gradação da complexidade disponível. Nesse sentido, no intervalo significativo de uma mesma categoria, há um leque de possibilidades de usos que dependem, naturalmente, do que cada escrevente dispõe como forma de contribuição pessoal.

No exemplo (25), ilustrativo da topicalização do segmento de tempo, o indivíduo faz parte do fato vivenciado, ou seja, não consegue se distanciar da construção do fundo informativo. Situa-se, assim, num tempo altamente concreto, demarcado pelo fato social e contexto temporal: 


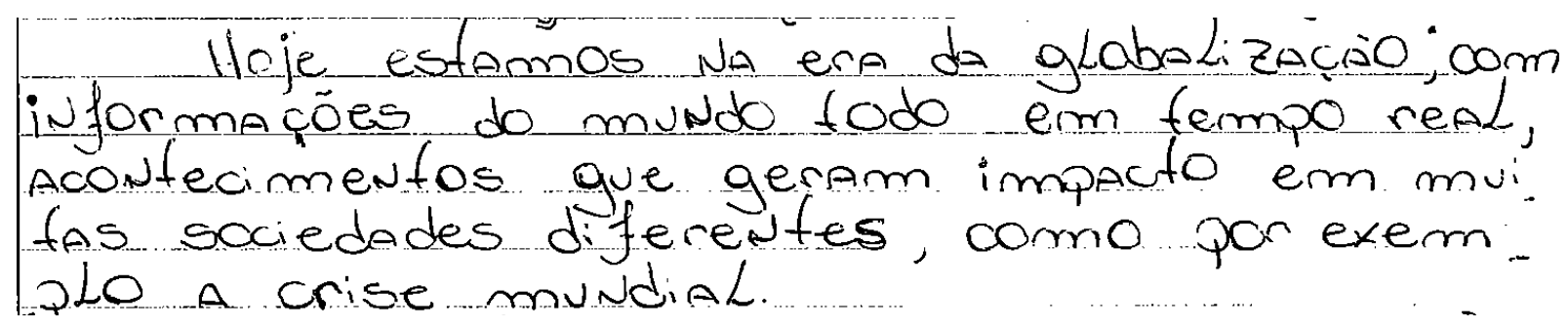

[(25) 1013592010 P28]

No exemplo (26), o estatuto informacional do segmento topicalizado é mais proeminente do que no exemplo (25). Diante disso, entendemos que o tempo avança para a direita no continuum, em virtude dos dados e especificações direcionadas ao conhecimento científico e filosófico que não são intrínsecos a todo indivíduo, pois dependem altamente das condições de vida. No entanto, o que lhe é agregado na vivência, pode ganhar em complexidade tornando-se uma realidade abstrata. Para isso, precisa-se permanecer em estado de vigília durante a escrita e focado no objetivo contextual. 


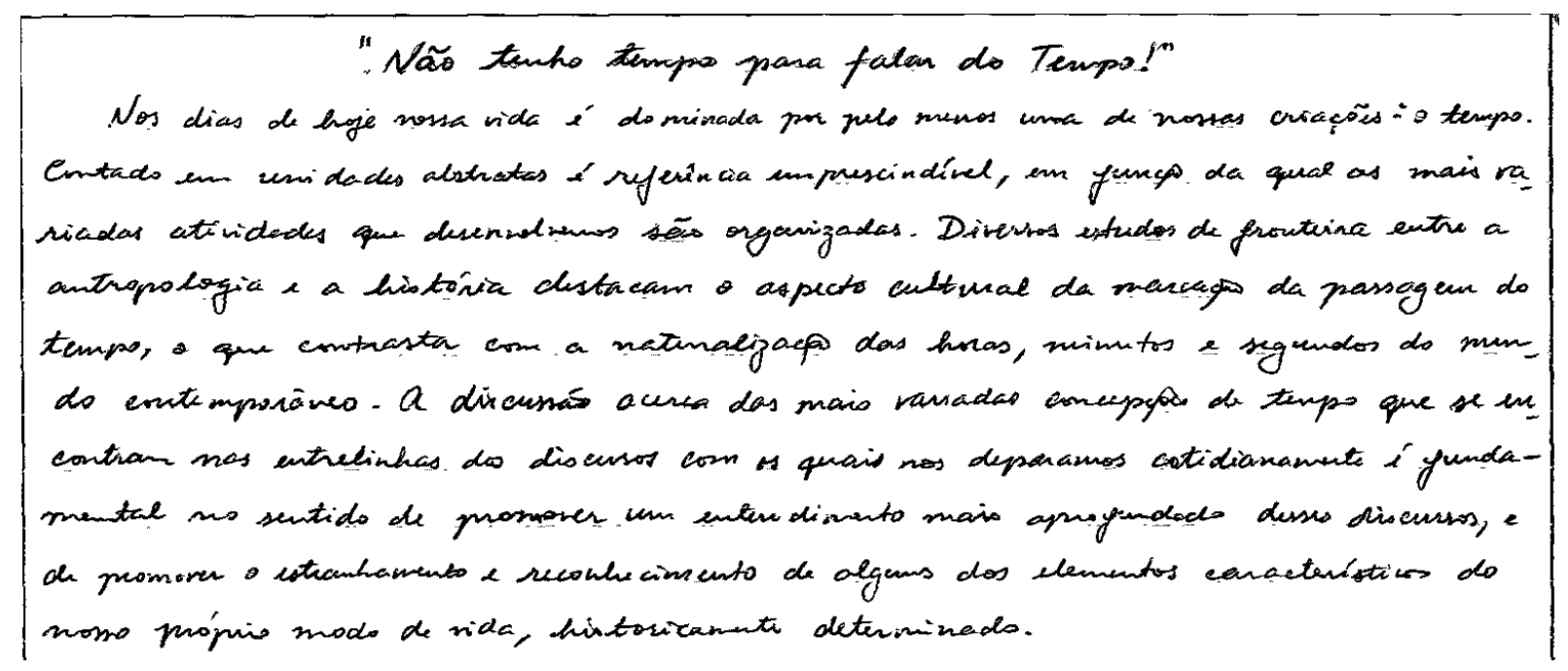

A comparação entre esses dois últimos exemplos permite a visualização do continuum abaixo:

- Complexo + Complexo (25) (26)

Continuum 4: Avaliação de tempo no continuum de complexidade

Esse continuum representa a fluidez a que nos referimos. Uma mesma categoria pode ganhar em complexidade a depender da forma como o candidato se coloca em diálogo, em que medida detém repertório para estabelecer o recorte temático e de que modo contribuirá com suas experiências de mundo. 
A ideia que subjazia à feitura deste capítulo, em suma, era saber se as notas atribuídas pela banca examinadora da FUVEST coincidiriam, em tendências, com o continuum de complexidade intuído durante as análises. A resposta veio em forma de alta frequência de usos (tokens), porém com diferenças quanto à adesão aos padrões (types).

Como a categoria de espaço revelou-se a mais frequente tanto nas melhores quanto nas piores redações (adotando o critério FUVEST), chegamos à conclusão, como já intuíamos inicialmente, de que a mente humana compartilha habilidades adquiridas ao longo de sua ontogenia e adapta essas habilidades a novos conhecimentos, tal como vemos nas redações dissertativas. Dessa forma, esperamos que esses resultados e reflexões possam se tornar subsídios para bancas de vestibulares, no que tange à consideração mais profícua do primeiro parágrafo, espelho mais lúcido das habilidades de adaptação do indivíduo que se constrói enquanto protosself na situação de face a face de conversa e se reanalisa como self central na adesão a modelos culturalmente disponíveis. No entanto, só pode se desenvolver em direção a um self autobiográfico se a sociedade, via diversos tipos de interação, puder propiciar a esse indivíduo repertório suficiente como matéria prima para sua inserção enquanto autor.

Essa é a razão por que concentramos atenção nas redações e na construção do espaço subjetivo. Se na fala, o chegar e o cumprimentar antecedem a conversa produtivamente, na escrita esse paralelo manifesta-se, na dissertação, no espaço da elaboração da tese. Não se pode aceder a ambientes aos quais não se possa 
frequentar do mesmo modo que não se podem construir espaços que não se tenha experienciado. É a iconicidade em sua complexidade.

\subsection{Mobilizando a bagagem discursivo-pragmática}

Assumir cegamente o rótulo adotado pela FUVEST - melhores e piores redações - significa assumir os critérios de correção das redações decididos por uma banca examinadora. Dado que os critérios não são acessíveis e que as decisões de banca durante o processo de correção também não são claras, decidimos por manter esses rótulos apartados dos critérios que adotamos para a análise nesta tese. Adicionalmente, sabemos que nem sempre os melhores alunos do ensino médio, ou os alunos que se prepararam muito nos melhores cursinhos, necessariamente obtiveram êxito na produção textual da FUVEST.

Também, é de conhecimento geral que a ansiedade, sendo um aspecto emocional relevante, pode exercer uma ação psicológica trazendo consequências físico-biológicas (dores na mão), intelectuais (esquecimentos) e psicológicas (nervosismo). Além desses aspectos, por certo, o cabedal de conhecimentos de uma pessoa, suas crenças, costumes, o grupo social de origem também influenciam na escrita de um texto.

Assumindo, dessa forma, que esses fatores interferem no processo de elaboração da dissertação, perguntamo-nos se o espaço destinado à tese, o primeiro 
parágrafo, poderia ser um bom material para se identificarem diferentes soluções de explicitação da tese baseada em priorizações feitas pelos candidatos. Como recurso teórico-metodológico, lançamos mão do princípio da iconicidade ${ }^{37}$, esperando que as priorizações do escrevente ficassem nesse espaço evidenciadas.

Um recurso auxiliar foi o controle da frequência de uso de cada estratégia para conformação da tese. Desse controle, sairia a relação entre marcação e informatividade.

Em muitos dos textos analisados, chamou-nos a atenção o fato de alguns candidatos iniciarem suas teses partindo da ideia de que aqueles que os vão ler sabem do que estão falando. Partem, assim, de informações pressupostas, que, na verdade, não o são. Considerando que estão redigindo para alcançar o objetivo de obter alta nota e de que pretendem ser compreendidos pelo membro da banca avaliadora, então, seu cálculo de compartilhamento de informações (espaço conjunto de atenção) apresentou-se, nesses casos, totalmente falho. Vejamos, a seguir, um exemplo dessa solução:

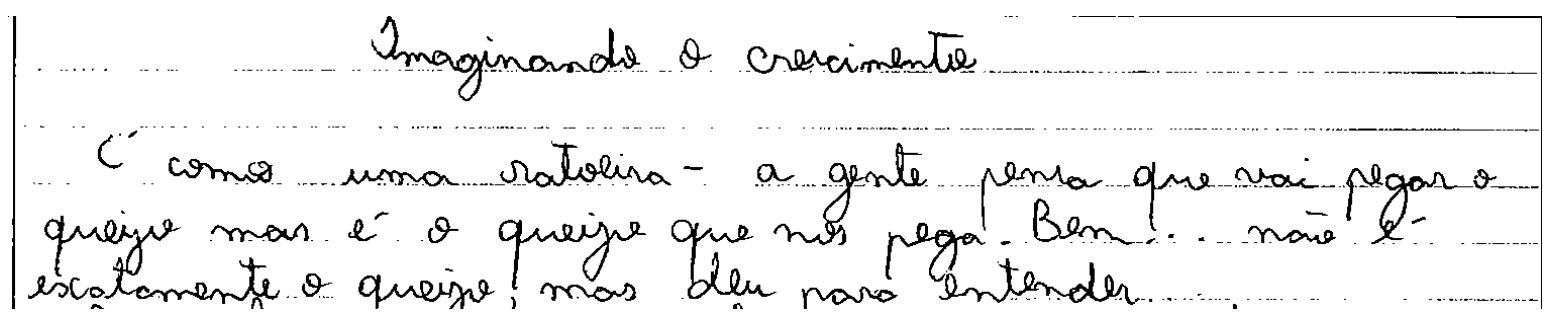

\footnotetext{
${ }^{37}$ Lembramos que sobre a transitividade, já explanamos na seção 1.1.4.
} 
No exemplo (27), o parágrafo introdutório pode ser analisado sob o ponto de vista do princípio da informatividade, pois nele é introduzido pela primeira vez um referente, considerado novo, e o autor do texto reforça o compartilhamento da ideia dizendo ao interlocutor "deu para entender".

Num grau maior de acessibilidade ou compartilhamento de informação, verificamos o caso em que um referente é inferível justamente porque os interlocutores são capazes de recuperá-lo no texto. Isso pode ser observado em:

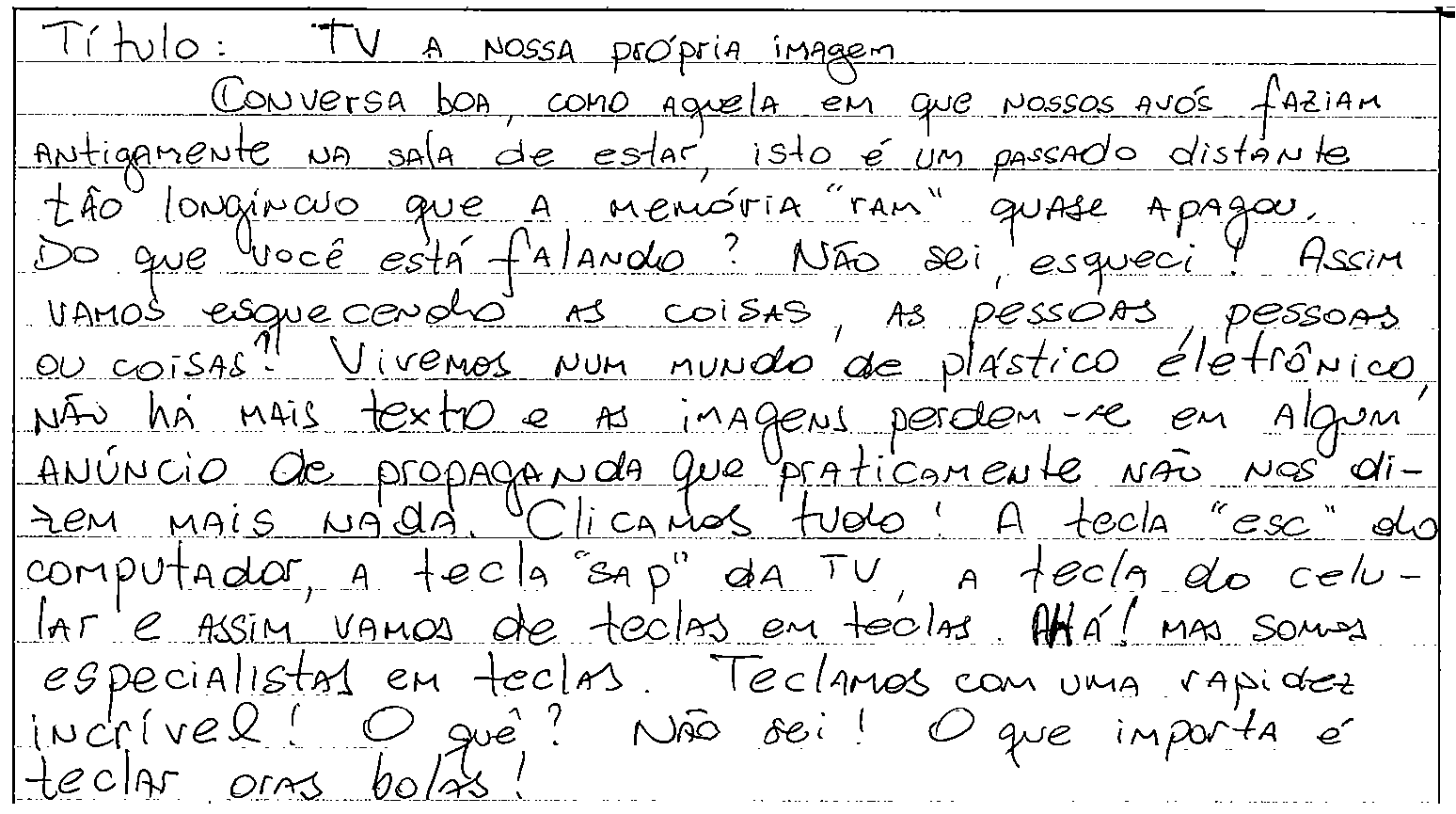

O exemplo (28), típica do estágio do protosself, considera que o outro está em sua frente, em sua presença e que sabe do que o outro está falando. Na primeira linha do parágrafo ${ }_{2}$ o termo aquela e as outras informações apresentadas ao longo do 
parágrafo permitem ao interlocutor inferir o que o candidato entende por uma 'conversa boa'. Pode-se, inclusive, construir uma imagem desse tipo de contexto.

Um referente pode ser dado, ou velho, se já tiver ocorrido no texto, no entanto observando nos dados das amostras sob análise, notamos que muitas das informações compartilhadas fazem referência aos excertos. Isso permite considerá-lo referente velho porque, de fato, tanto para o locutor (que leu para elaborar a redação), quanto para o interlocutor que certamente é o avaliador ${ }^{38}$ do texto, as informações já são conhecidas.

Vejamos o exemplo (29):

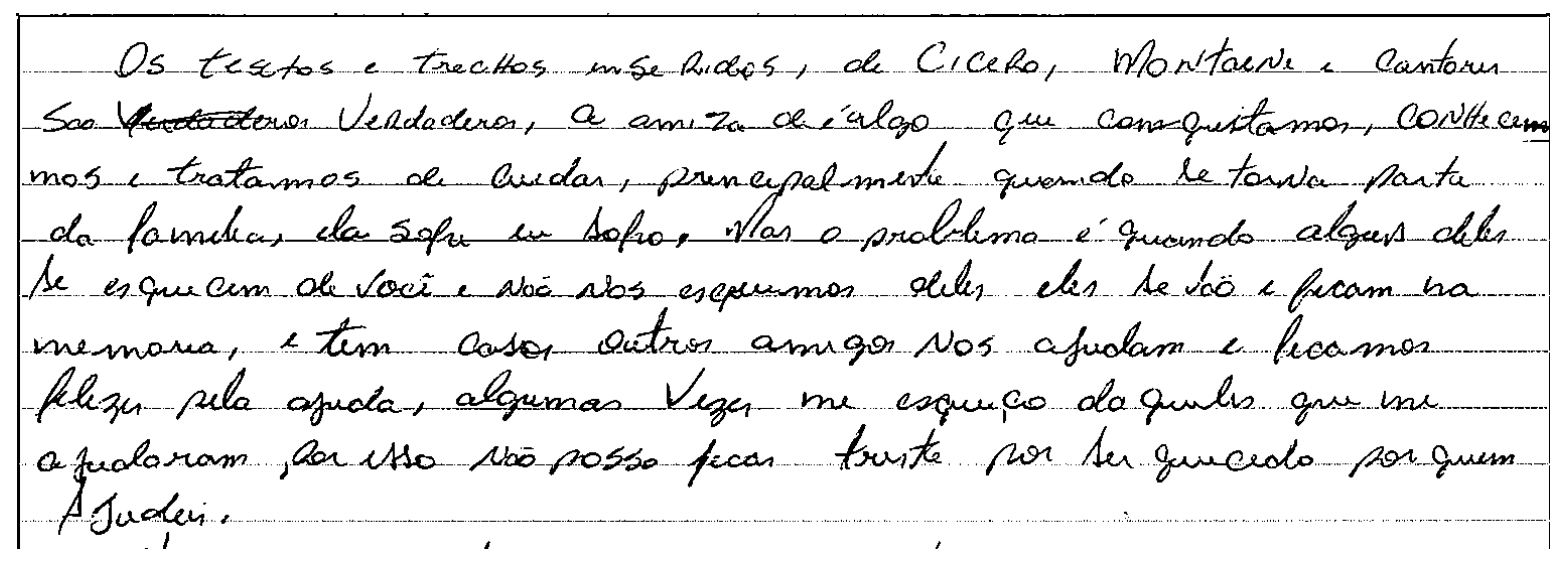

Quando é feito alusão a "os textos e trechos inseridos", o candidato remete aos fragmentos da prova que contribuem para que ele reflita acerca da linha que deverá desenvolver. No entanto, para alguns candidatos esses excertos fazem parte dos seus

\footnotetext{
${ }^{38} \mathrm{O}$ candidato sabe que quem vai ler é o avaliador e consequentemente já conhecem os excertos, isso faz com que eles considerem as informações já dadas, então não veem necessidade de primeiro contextualizar o leitor.
} 
textos e, por isso, são apenas retomados. O candidato não se preocupa com a possibilidade de seu texto ser lido por alguma outra pessoa que não tenha tido acesso aos excertos, pois para o autor da redação essa possibilidade é remota. Em sua consciência, ele tem clareza da situação e da finalidade do próprio texto. Diante disso, o candidato está apenas lançando mão da virtualidade do sistema, traduzida pelo princípio da informatividade. Observemos os exemplos

\section{Jragédia economicamente viável}

(1) mundo se encontra hoje repleto de conflitos étricos, religiosos, econômicos e políticos; porém dentre tantos enciste um que merece um destaque especial, a "guevira contra - Terrorismo" declaroda pelo ontigo presidente americono ge-.. orge $W$ Bush, orrde os Estados Unidos comprometeram-se a inturver militarimente em regioes onde se desenvolvecem atividades terristas ou liadras a elas.

[(30) 1007732010 P15]

\section{Imogo}

Desde a antiga entenda entre flotāo e Ouritótules puonto a naturga benéfica ou maléfica da imagem, $\theta$ homem ocidental está às voltas com essa puestäo arsm como fellogrini, o viodor do mito da caverna concebia a $i$ mogem como uma pirigosa mediadora entre os nasos shos 1 a vecdade. Seu dis cípulo, por sua ves, entendia a imogem como a mair atta forme de verdode entre os homens e, arrem como Durand, deredutava no poder harmonijodor da mimese. Ha seludade contemporonea, exa fuestä vem od quirindo novos contornos com a delereda proluerocăo de míllas veruais (mediadores) e

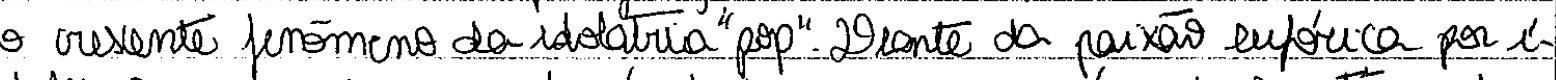
dolos peu so conhecenos draves de imogent, rema rérue de peuestors relate vas as relocuonomentos intrupessoaes verm à tona: att fue ponto l possivel contucer alquém ce a rimosmot)? Quondo se ona, o fue re ama?

[(31) $1273772009 \mathrm{M} 1]$ 
Enquanto no parágrafo (30), o segmento "o mundo " desempenha a função de sujeito (função sintática), mas assume concomitantemente o papel de fundo espacial para a construção da tese (função pragmática), a construção do parágrafo (31) apresenta topicalizado o segmento "Desde a antiga contenda entre Platão e Aristóteles (...)", que não acumula as funções sintática e pragmática, mas se especializa na segunda e cria a ilusão de um background mais complexo, deixando a função sintática para uma posição subsequente (o homem ocidental).

Quanto à iconicidade, conforme definimos no capítulo I, trata-se de um princípio que coloca emparelhados o código linguístico (expressão/forma) e seu significado (conteúdo/função), é concebido como uma solução cognitiva para a relação de um para um, permite reconhecer que, quanto mais complexo o pensamento, mais complexa será a expressão. Por outro lado, quanto mais simples o pensamento, mais simples serão os mecanismos morfológico e gramatical pelos quais se expressam. Logo, observemos os exemplos:

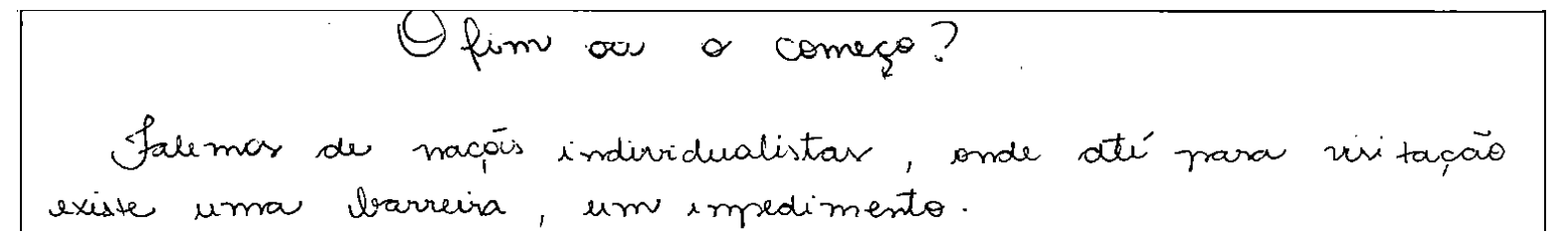

[(32) 5000242009 P2]

Olimite é nosso
As pessoas se limitam a fazer coisas por medo
á que está a sua frontira, vocé quem diz onde
quer chegar. 
Os parágrafos de introdução (32) e (33) são resultados do estágio do protosself, pois a escrita, embora seja um exercício de distanciamento de uma conversa, na cultura de papel, esses candidatos não percebem isso. Esses exemplos mostram que eles sentem-se na presença do interlocutor e fazem da produção escritauma conversa, ou seja, uma situação de face a face. Também é possível notar, ainda nesses exemplos, a atuação do subprincípio da quantidade, pois ao apresentar apenas um período, em vista do pequeno número de orações, da organização sintática direta que segue a estrutura Sujeito - Verbo - Complemento (SVC) e do pouco contexto semântico que trazem ao interlocutor percebemos a simplicidade do pensamento. Agora, tomemos por base os parágrafos abaixo:

\section{Liquefagaio Social}

En sua sbra "Msdernédode Líquirda", o scciólogs Bauman retrata o esfacelam ento do tecido social e suas con sequências no âmbito dos telacionamentos humanss atrouvés da metaffora da liquefogä das relacoves interpessocis, da subjetividode e da liberdade dounidiróluo. Tudo derrete-se iereuersivelmente, toman. do parodoxalmente, a am sifabilidode do estodo líquido. Analisandó esse contex. to atrelodo à confunturo atual, nota-se que, assim ans é descrito pelo pensudor polonês, as relacöes sociais tornam-se coda vez mais líquidas. Gradativamente prevalecem valores coms s eqgismo, em detrimento de outios coms a solidariedade.

[(34) $1366852011 \mathrm{M} 1]$ 


\section{$O$ homem ec superaçã à sua fronte: pronteiras}

Em 1750, quando Portugal Clevolveu Sacromento à Esponha e em troca re aporsou das terras a oeste de Yordesil has, a parte majoritónia da fronteira brasiliera se definies Outro trotado de relencincia, além do suprocitacto Tratodo de Modri, éo de Petrópolis, ó qual nos rendeus o here. Koje, em grito retumbante, brodamos a extemsa fronteira em que vion. Ga a soberamia macional. Ixomicamente, nesta época de fronteiras defincidas, uma operadora

[(35) 5087072009 M60]

Comecemos pelo número de períodos apresentados nos exemplos (34) e (35), temos de quatro e cinco períodos respectivamente, um grande número de orações no mesmo parágrafo, na organização sintática ambos foram iniciados com elementos acessórios da oração e finalmente o contexto semântico é bastante ampliado à medida que cada oração colocada no parágrafo aumenta a compreensão que vai se produzindo ao longo da leitura. Enquanto em (32) e (33) temos menor quantidade de informação e menor quantidade de forma, o que significa que aquilo que é mais simples se expressa com o mecânismo morfológico e gramatical menos complexo, em (34) e (35), ambas originadas de um self autobiográfico tivemos exatamente o contrário, maior quantidade de informação e forma, e consequentemente uma expressão mais complexa do mecanismo morfológico e gramatical.

Ainda no princípio da iconicidade também é possível perceber a integração dos conteúdos que se dá tanto no âmbito semântico quanto sintático, de forma que não conseguimos se quer separar sintaxe de semântica, ou seja, a integração é tão intensa, que se incorrermos na mudança da estrutura sintática, podemos também incorrer na 
mudança de sentido, e até mesmo num entendimento equivocado em relação ao sentido que o autor do texto gostaria de trazer. Ao observar o exemplo (35) vemos que Portugal ( $1^{\underline{a}}$ oração) é sujeito do verbo se apossar ( $2^{\underline{a}}$ oração). A expressão "outro tratado" integra-se com "supracitado tratado de Madri" que por sua vez retoma o apossamento das terras de Tordesilhas. A proximidade dos elementos que se articulam reforça mais o subprincípio da integração, que por sua vez nos leva a outro subprincípio da iconicidade, a ordenação linear. Ainda no mesmo exemplo, podemos perceber que ao descrever os eventos o autor atende a sequencia temporal em que os fatos aconteceram, historicamente primeiro aconteceu o tratado de Madri, depois o de Petrópolis até chegar nos eventos dos dias atuais, apresentado no texto pela expressão temporal "hoje".

O princípio da marcação que se caracteriza pela complexidade estrutural, pela distribuição da frequência e pela complexidade cognitiva e remetem ao contraste de dois elementos "marcados" e "não-marcados" de uma categoria linguística. Para o nosso campo de trabalho, escolhemos a categoria sintática para estabelecermos os elementos de oposição.

Considerando esse princípio, observamos que é muito mais frequente um parágrafo iniciar com uma afirmação/declaração do que com uma interrogação. Na situação de interrogação há, de fato, muito mais esforço por parte do interlocutor, que já é interpelado no início do texto, tendo de refletir sobre o contexto que se espera que seja discutido. Quando o locutor faz uso do recurso de questionamento no início do 
texto, o primeiro efeito que gera no interlocutor é a expectativa, no entanto tal expectativa pode ser concretizada ou frustrada durante o desenvolvimento do texto.

\section{Hronteira Precológica.}

pensando psicologicamente apé que ponto o homem pode chefiar a mente dO próximo?,COM o aUAWGO DOS ESTUDOS NÁO FALTARÁ MUITO PARA O ROMDIMENTO DAS NOSSAS FRONTEIRAS PSICOLOEIICAS.

[(36) $5000592009-\mathrm{P} 3]$

Algums coise esta fors dx owden!.

frontoira! quais as nossas frontsiras? Há as fromteri-

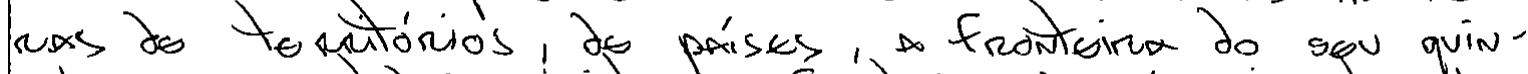
Ad con o guintan do virima, * Frosteirna do ciencia, teando-

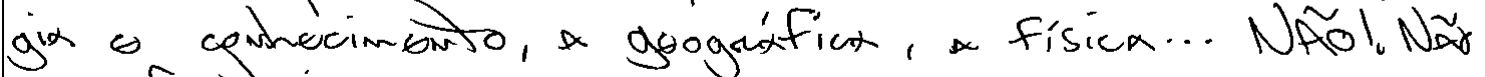
ossos fronteirs ...

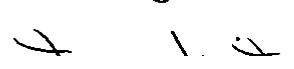

[(37) 5000822009 P5]

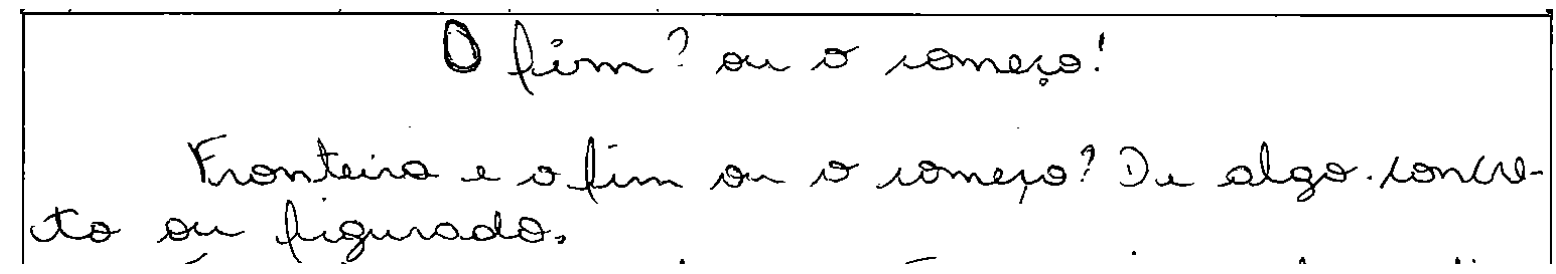

[(38) 5004072009 P19] 


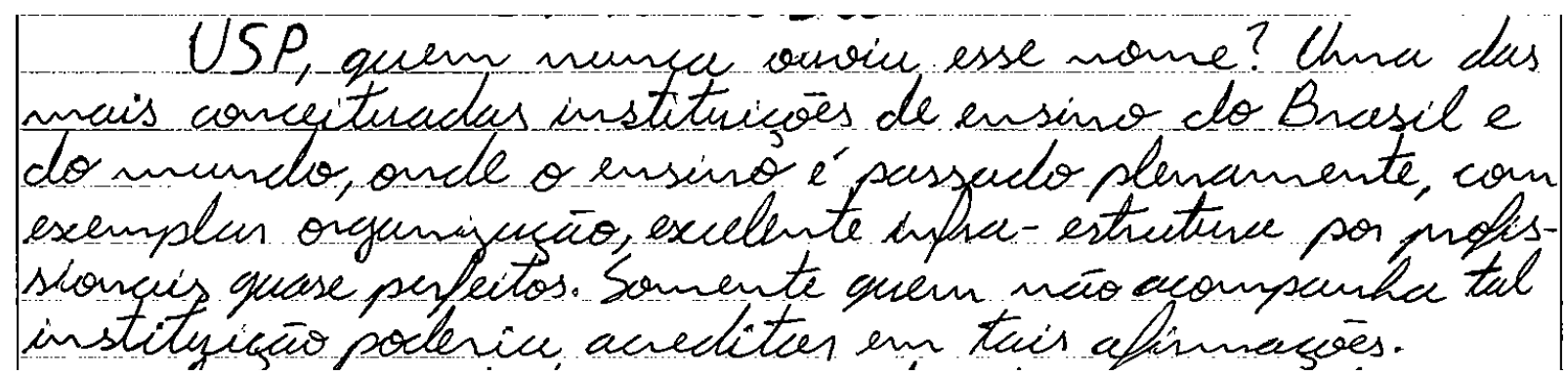

[(39) 1010652010 P20]

É notável que mesmo em introduções em que o locutor lança mão do recurso de perguntas, tais questionamentos constroem um fundo para induzir o interlocutor a uma leitura persuasiva. Em alguns casos, servem de base para serem refutadas durante a argumentação. Desta forma, o questionamento reflexivo serve instrumento para a defesa da tese.

Quanto à estrutura sintática, o parágrafo introdutório pode ou não seguir a organização SVC.

\section{Frontuivas: relativizar nãa é perder}

Há dois significados, pelo menos, para a palaura frontiva: um uspacial, que pode

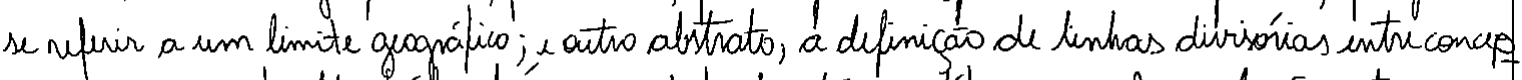

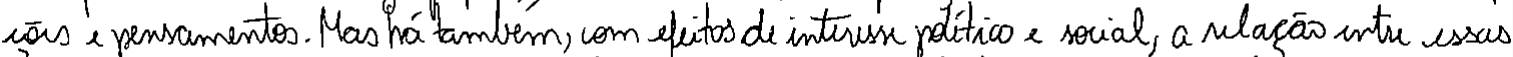
duco acepsés, a relacāo que se laz entre conviccoós idedógicas 20 desenho do expaço geo gráfico, intre dogmas e o comportamento de posse, que limita áreas físicas de existincia dos grupos humanos. Desse modo, í relevante a discussãa de como a construção de idias (e suas frontivas) organiza o quadoo publemático do homenn em soric dade.

[(40) 5003152009 M31] 
Qivisov de "águas"

Vilas, cidades, estados, pauses, toodos divididos pou frenteiras, separados territorialmente e até psico-pocialmente pou esta linhas imaiginariaj que as rezes nem täo imaginária assin, se comperta como uma bavrevia entre es pouss.

[(41) 5281802009 M45]

Quando o sintagma não obedece à estrutura SVC, bem como quando não há a presença de expressões temporais e locativas no início do parágrafo, percebemos que há uma tentativa mais significativa e complexa para contextualizar o leitor, que podem se apresentar na forma de estruturas mais abstratas, trazendo uma ideia de localização, porém não de tempo cronológico, nem de lugar físico, mas de estrutura que situa o leitor em determinado contexto.

Limites da sabedoria

Da antiguidade aos dias modernos, os seres humanos organizam-se em grupos e comunidades. Conforme tais sociedades crescem, oria-se e amplia - se o conceito de fronteira, is to é, os limites geográficos e socizis de determinada região. Este conceito, náa obstante, expande-se além do sentido físico a medida que evoluem as pessoas a ele submetidas. Fronteiras abstra tas são criadas, indicando a abrangência do estudo científico, da comunica G.̃o, da diversidade, entre outros Porém, este tipo de fronteira difere daquele da definiczoo geográfica quanto a interpretacão:enquanto divisas políticas existem para serem respeitadas, os limites do que a humanidade é capaz existem

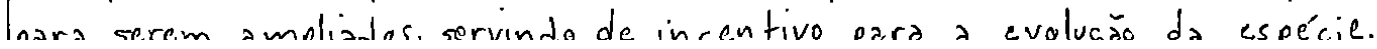

[(42) $5025142009 \mathrm{M} 16]$ 
Desde tempos remotos, o homem viou justomente com outhos homens. Tal realidade se deur e ainda é visúel hoje, até de certa form a fortalecida, em decorréncia de um fator principal: o homem é um ser rociável. Todovia a xciatilidade humana nás re presenta una opcāo, mas uma necessidade básica O homem năs tém a capacidade deviver rozinho risolado, pois ele apresenta a necersidade de ciar relacois com outhos

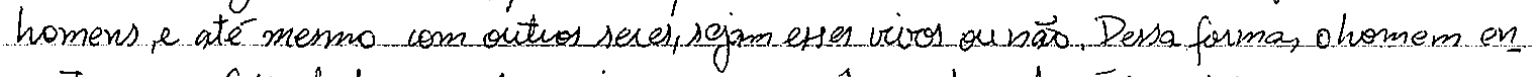
contra ma felicidade quasdo sacia a sua coréncia de relagues sociais, on seja, um ser Iurmano obtén sua realizacás na conviếncia com a autio Devido a essa realidade, a amizade é uma das formas do homem atingir sua felicidade.

[(43) $522942522942 \mathrm{M} 94]$

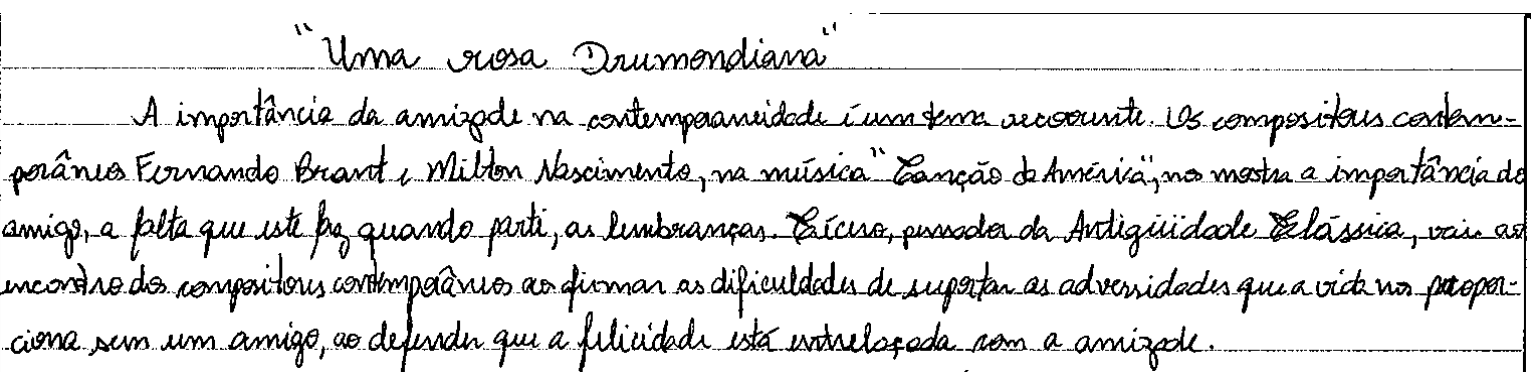

[(44) 535223 2007- M79]

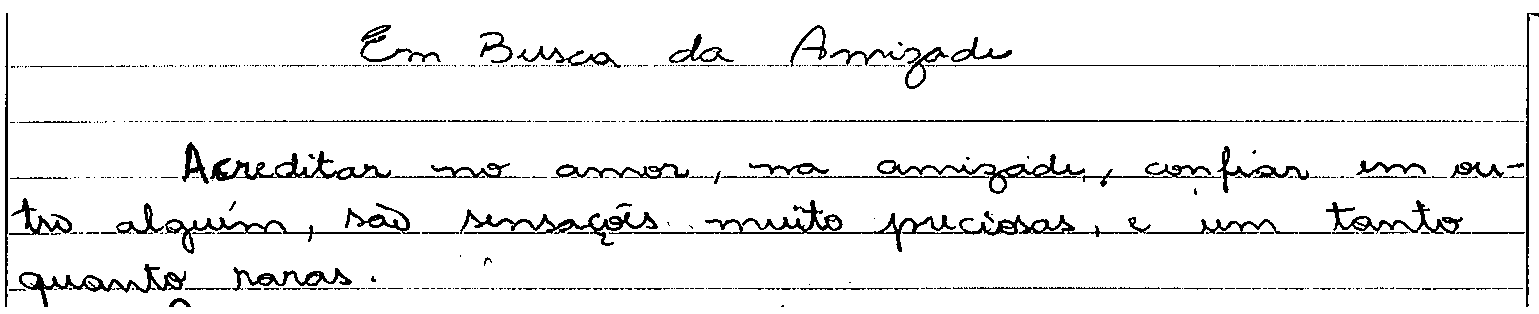

[(45) 5011272007 P28]

No texto abaixo o candidato relaciona o tema "imagem" à obra de Magritte, fazendo alusão ao conhecimento enciclopédico, ao conhecimento humano que não 
necessariamente foi vivenciado, mas, que por exemplo, foi adquirido por diferentes leituras.

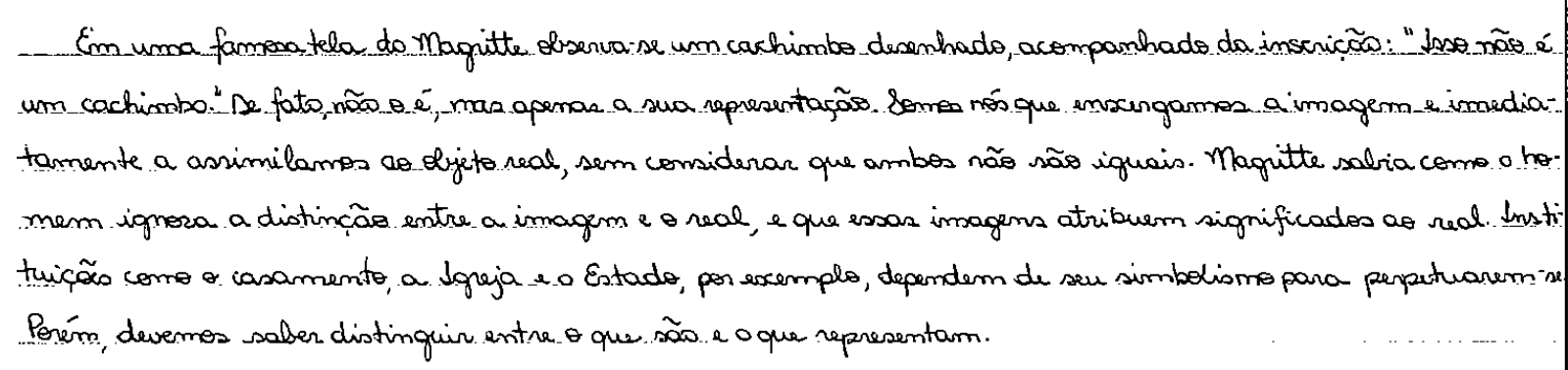

[(46) 1302542010 M23]

Outro exemplo é quando o candidato faz referência a Guy Deborad, em que usa o recurso de intertextualidade explícita trazendo à tona o conhecimento enciclopédico sobre as questões filosóficas discutidas por este escritor.

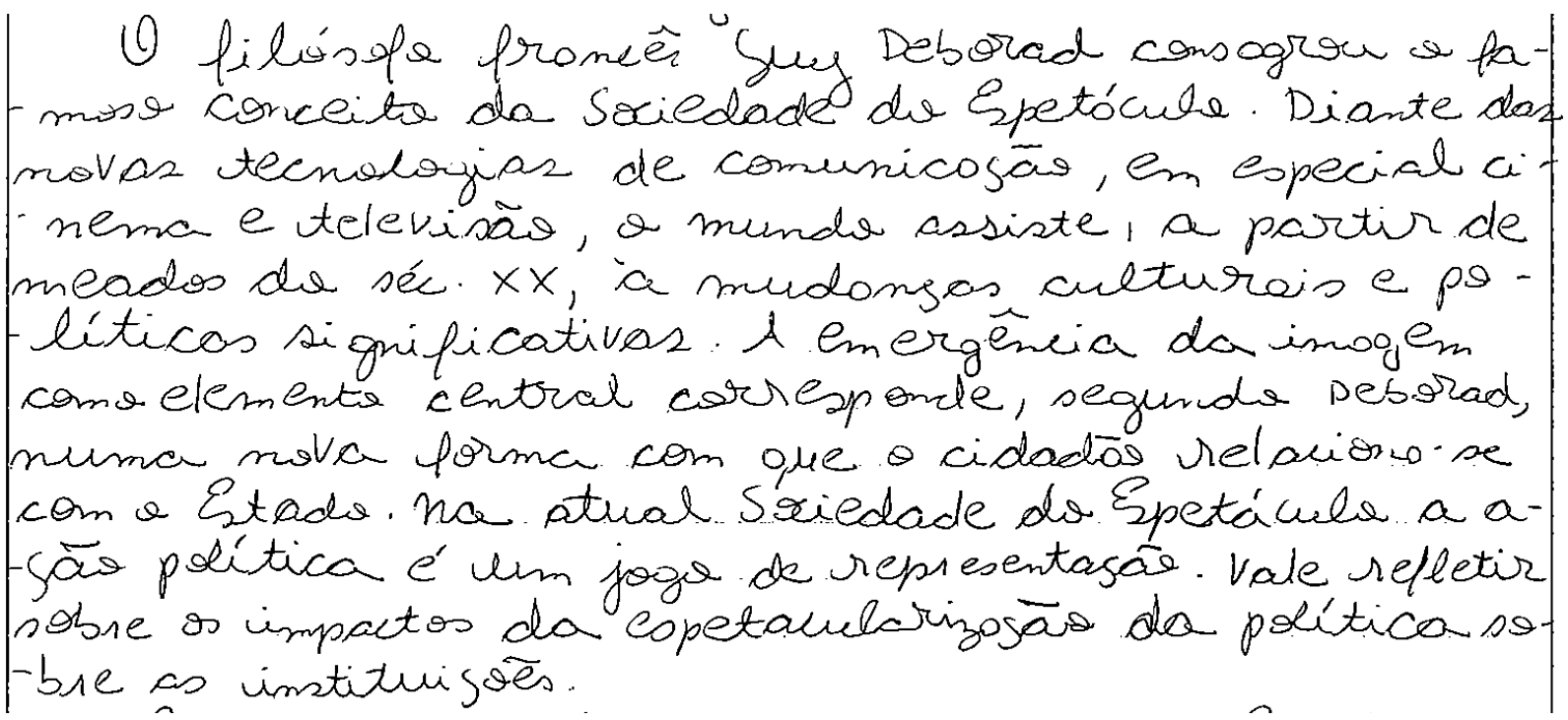

[(47) $1038182010 \mathrm{P}$ ]

É notório nas redações classificadas como as melhores a presença do rico repertório intertextual alusivo a fatos ou personagens históricos, que não fizeram parte 
das experiências pessoais do indivíduo, diferentemente das redações classificadas como as piores, em que ao invés dereferências enciclopédicas as alusões são feitas às experiências pessoais, marcadas por eventos espaciais e temporais, em geral, vivenciadas.

Observamos nas redações, a grande frequência de uso dos termos: "nos dias atuais", "atualmente", "nos dias de hoje", "no mundo de hoje". Isso pode ser explicado pela imitação, que junto com o conformismo e com a solidariedade, implica duas consequências: a primeira é o desejo de compartilhar emoções com os outros, e a segunda é a pressão de se conformar com regras e normas sociais, sem as quais o indivíduo seria excluído do grupo. Isso explica os candidatos procurarem uma "fórmula" para a escrita ideal de um texto. O problema é que mais do que conhecer uma estrutura textual, é necessário outros elementos, tais como informações políticas, sociais, econômicas, culturais e históricas para contribuir com a qualidade do texto. Embora não tenha sido o foco de Tomasello, como vimos parece-nos que ele já relacionava a segunda consequência às condições de produção textual, que, no caso da FUVEST, exige que o candidato cumpra com as regras da norma culta e atenda às normas de contratação.

Um estudo apresentado por Bybee (2010), acerca das combinações de formas verbais com can e can't que se tornaram convencionalizadas, algumas com função discursiva ou significados especiais e outras vão mostrar que, examinando usos especiais de can $+V$ e $\operatorname{can}^{\prime} t+V$ em contextos altamente frequentes, é possível obter pistas da relação entre funções específicas e funções mais gerais. Ela apresenta uma 
análise das construções com esses seis verbos (can't seem, can't believe, etc.), demonstrando que não é a expressão com um verbo que se torna convencionalizada, mas, sim, algum sentido apresentado numa situação particular é que se tornou convencionalizado. Isto é, existem diversos casos que permitem concluir que, na repetição de uso de algumas unidades linguísticas com algumas inferências contextuais, as inferências passam a fazer parte do significado. Para ela, morfemas gramaticais são sempre parte de uma construção e seu sentido só pode ser inferido dentro do sentido da construção como um todo, uma vez que um mesmo morfema gramatical, quando instanciando construções distintas, pode assumir contornos semânticos também distintos.

$A$ construção $\left[E M+E^{39}\right]$, é uma construção pré-fabricada que, em situações interativas da modalidade escrita, resulta em alta frequência de uso. Essa construção cria um background seguro para o candidato apresentar sua tese em um tipo textual dissertativo-argumentativo.

Na fundamentação teórica desta tese, hipotetizamos que a margem esquerda da sentença propicia a construção de chunks espaciais. Complementarmente hipotetizamos que quanto mais o espaço for construído à direita, mais elementos demandará para a sua contextualização. Vamos à checagem dessas hipóteses considerando o primeiro parágrafo das redações (48) e (49):

\footnotetext{
39 “E”'representa espaço.
} 
Na construçäs dos valores modermos, a sociedade seguius imperativos capitalistas do modelo do "american way of life". Dentro dessa estrutura, o padräo hegemônice permeou o imaginário humano a tal ponts, que hoje se obserna um painel vocial massificado no tocante aos gostos interesses e objettivos, fato que, a promover uma régida e pruel mormatizacãos entre "incluído"

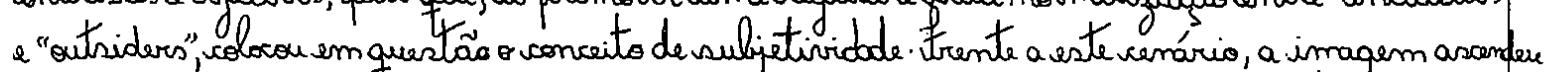
como instrumento fundamental ma construçä das persoas, surginds, dá, o questionamento

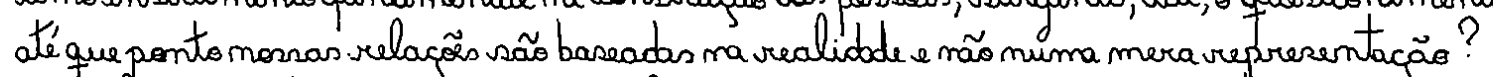

[(48) 1231802010 M 23]

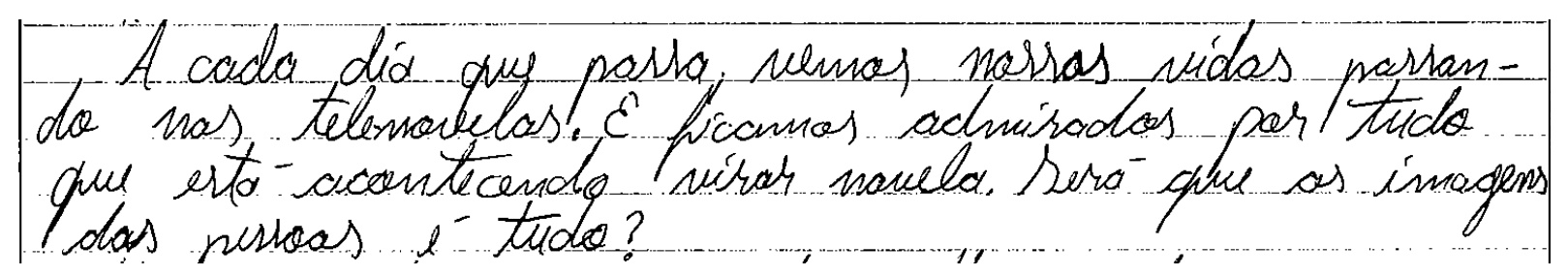

[(49) 1011122010 P41]

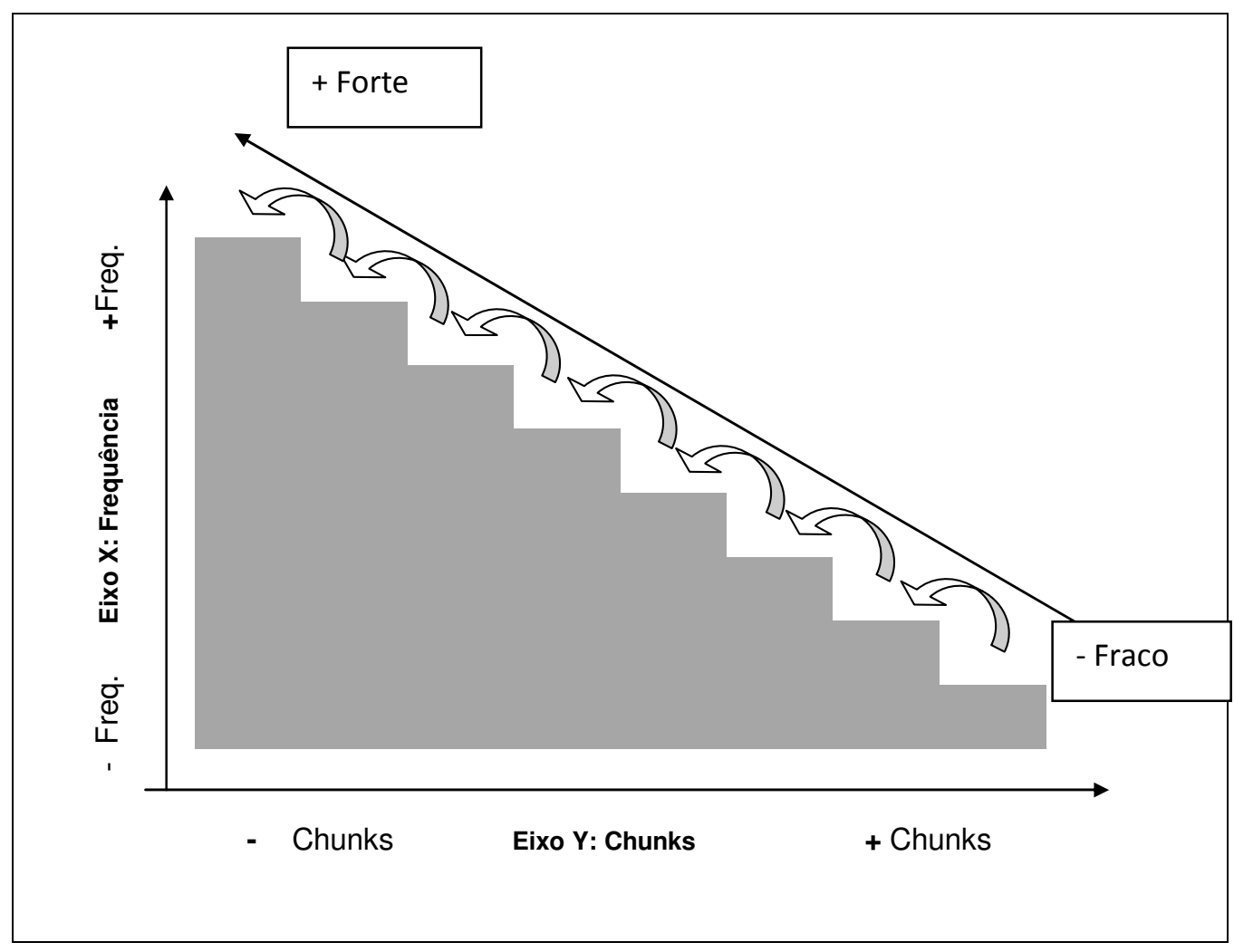

Quadro 14: Graus de complexidade dos chunks 
Tendo em vista que o espaço para a construção da (inter)subjetividade ganha força à margem esquerda da sentença, hipotetizamos que toda vez que o chunk espacial está mais à esquerda na sentença, menos chunks serão associados a ele e mais recorrente o chunk espacial será. Contrariamente, quanto mais o chunk espacial estiver localizado à direita mais associado a outros chunks ele estará e menos recorrente será. Em termos da construção de uma tese forte, o espaço à esquerda é assim mais fortalecido - e seguro - do que à direita, em que demandará mais informações devido a ser mais fraco.

\subsection{A polaridade negativa no parágrafo introdutório}

A asserção é menos complexa do que a negação. Isso sabemos. Escrever algo que se nega é muito mais complexo, portanto. Assim, considerar a polaridade negativa parece ser uma boa pista para identificar graus de complexidade de teses também.

Sua baixa recorrência em parágrafos introdutórios é plenamente explicável, pois apoiando-nos em Givón, (1979), um ato de fala negativo pressupõe a rejeição às convicções dos ouvintes no contexto da afirmativa correspondente. para transmitir informação nova no contexto de ignorância do ouvinte; além disso, conforme o Princípio de Pollyana, descrito por Matlin and Stang (1978) e citado por Givón (1979) os humanos descobriram que acreditar é mais reforçador do que duvidar, a certeza mais do que a incerteza, a plenitude mais do que a escassez, asseverar mais do que negar. 
O exemplo a seguir mostra uma tese em que o candidato tenta fazer uma construção negativa, no entanto exatamente por usar duas negativas acaba construindo uma afirmação mais complexa, que é ampliada ao longo do parágrafo.

Nä se pode negr o xcelerado ritmo com que o unudo prssa por mudancas profundas nas relasas humanas derde que vivemos a Ero da Informasão. De fato.

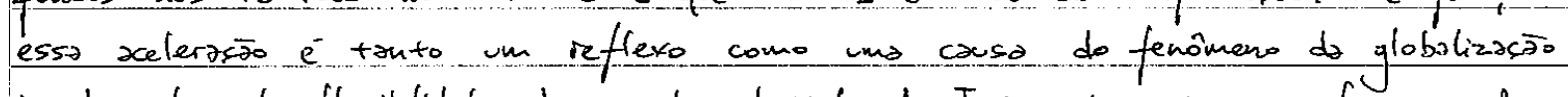
impulsionada pela flexibilidate do mundo digital. A Internet maior manifestazà deste ud atualidade, aparece para muitos como a meca do livre expressão e, ainda mas, do live acesso a informacōo. Se por un lado isso propicia enormes possibilidates de inclusão social e intelectual $e^{-}$tambēm un prato cheio para faudes e a divulgacjo de informasses erradas e opiniöes impropanias.

[(50) 5168902008 M20]

\section{Enve thecer}

Nào há como se livrar dele, algo que cai sabre todas as pessoas é o tempo Que pode 1er dividido em fisiológico e psicológico

[(51) 5168392004 P41]

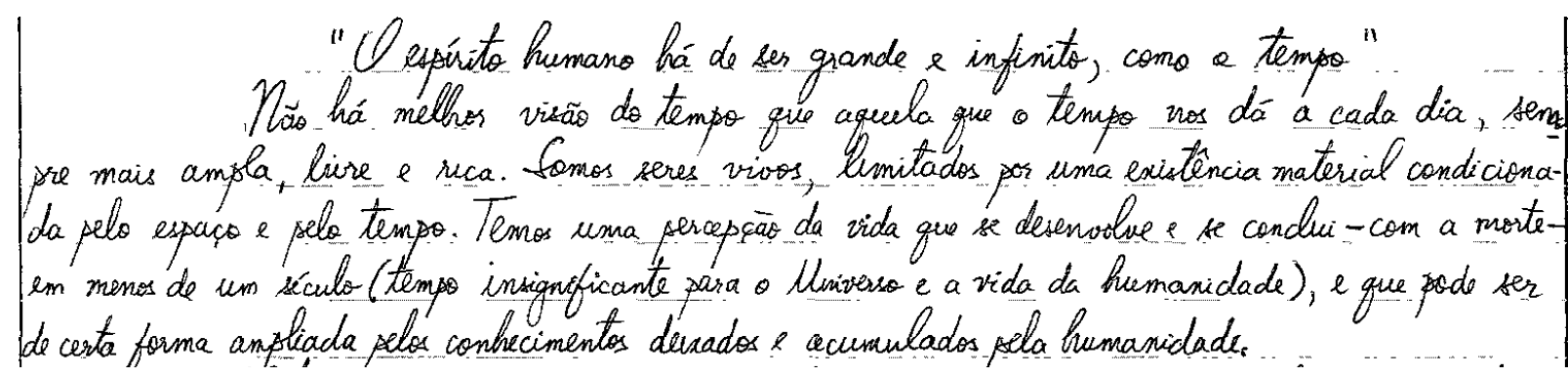

[(52) 5119702004 M16] 


\section{Tempo Histórice}

O. tempo nöa pade ses visto, degus tado, avido tateado au cheisado. E' uma.

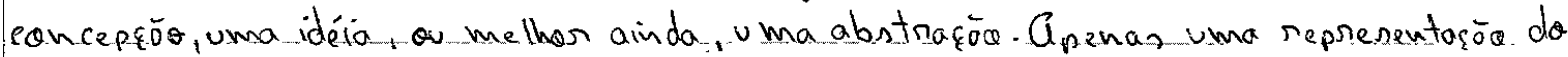
tempo pode ses percebida pelas sensagées humanas, como un selógio que é uma representaciöe espacial do tempo, ou camo os cabelas brancos creseendo que säo um rinal de que o tempa pansa, man nunca o tempa em si. Ense, pode nem excintis.ope har de res una idcia abritrata, cencepgées obre o tempo podem rar feitan.

[(52) 5247162004 M26]

Dada essa complexidade, exige-se uma codificação sintática também complexa, daí a presença de verbos apresentacionais, de construções indeterminadas e de sujeitos abstratos e atípicos. Nega-se a informação de modo altamente elaborado, pois seria muito simples e básico se se afirmasse a tese. A opção por esse tipo de construção indica a presença de uma pressuposição geral, que se nega para dar lugar ao sujeito que constrói um novo espaço de chegada.

\subsection{O discurso do livro didático}

Como identificamos padrões de comportamento do escrevente convergindo para a construção do espaço interlocutivo, consideramos procedente verificar se essa solução é fruto de um treinamento escolar. Essa é a razão por que, nesta seção, apresentaremos a análise dos três livros didáticos selecionados para a investigação do impacto escolar na decisão da construção do primeiro parágrafo. 
Lembremo-nos de que aventamos, nos capítulos iniciais,a hipótese de que a abordagem do texto dissertativo-argumentativo pode ter sido influenciada pelas orientações do livro didático. Se estivermos corretos nesse raciocínio, então o peso da sala de aula na formação do indivíduo que redige textos ontribuiria para a prática de escrita do parágrafo dissertativo inicial, o da tese.

As três obras selecionadas assumem a forma de volume único, são aprovados pelo Programa Nacional do Livro Didático para o Ensino Médio - PNLEM - 2009 e são amplamente adotados por escolas públicas e privadas do ensino médio. São elas:

- Português de João Domingos Maia - Volume Único;

- Português: Linguagens de William Cereja e Thereza Cochar - Volume Único ${ }^{40}$;e

- Textos: Leituras e Escritas de Ulisses Infante também Volume Único.

A obra de João Domingues Maia é organizada em volume único, dividido em 47 unidades, constituídas das seções: Margens do texto, Horizontes do texto, Intertextualidade, Exame de textos, Literatura, Produção de textos e Gramática. A seção de produção de texto é trabalhada em todas as unidades, no entanto são focos de desta pesquisa as unidades que apresentaram sobre o tema dissertaçãoargumentativa.

\footnotetext{
${ }^{40}$ O PNLEM 2009 analisou o livro de Português: Linguagens de William Cereja e Cochar em 3 volumes, no entanto comparamos a parte de produção textual que aborda sobre texto dissertativo-argumentativo e verificamos que é idêntica entre os exemplares. Então desenvolvemos a pesquisa a partir do volume único, tendo em vista pertencer ao nosso acervo pessoal, o que viabiliza maior facilidade de acesso e permite que pudéssemos manter o padrão de análise em relação às demais obras que foram aprovadas pelo PNLEM em volume único.
} 
De modo muito superficial, a unidade três da obra de Maia apresenta a definição de texto e de suas tipologias: narrativo, descritivo, informativo, argumentativo, injuntivo e poético. Vejamos a explanação sobre o texto argumentativo:

\section{Texto argumentativo}

O texto argumentativo procura convencer, propondo ou impondo ao receptor uma interpretação particular de quem o produz. Por isso mesmo, visa defender uma tese ou rejeitá-la.

Os textos argumentativos não se confundem com os textos informativos, pois, nestes, os fatos e ideias não são geralmente expostos com o objetivo de convencer o receptor.

Em geral, o desenvolvimento de uma argumentação comporta as seguintes etapas:

- uma tese ( ou ideia diretriz), que enuncia o ponto de vista que será objeto de demonstração;

- os argumentos, elementos abstratos geralmente apresentados em ordem crescente de importância e que justificam a tese; fatos, exemplos, citações de autores ou peritos reconhecidos ou dados que ajudam a provar a validade da tese. Em muitos casos, dependendo da finalidade e da audiência, podem incluir apelos emocionais.

\begin{tabular}{|ll|}
\hline \multicolumn{1}{|c|}{ FUNÇÃO } & \multicolumn{1}{c|}{ CARACTERÍSTICAS } \\
Procurar convencer; & $\begin{array}{l}\text { Predomínio do presente do } \\
\text { indicativo e/ou do pretérito; }\end{array}$ \\
$\begin{array}{l}\text { Apresentar ou defender } \\
\text { uma tese, um ponto de } \\
\text { vista; }\end{array}$ & $\begin{array}{l}\text { Desenvolve ideias ou } \\
\text { argumentos; }\end{array}$ \\
$\begin{array}{l}\text { Quando polêmico, tomar } \\
\text { partido contra ou a favor } \\
\text { de uma pessoa, grupo ou } \\
\text { uma instituição e suas } \\
\text { ideias. }\end{array}$ & $\begin{array}{l}\text { Uso de oposições, antíteses; } \\
\text { frases de tom categórico; }\end{array}$ \\
\hline
\end{tabular}

Sem exigir muita reflexão do aluno, depois de apresentar os conceitos das tipologias, há um único exercício, composto de cinco fragmentos que devem ser 
classificados de acordo com os tipos de textos sem proporcionar qualquer dificuldade ao aluno. Posteriormente, já na unidade 9, na seção de produção de textos, o autor explanará sobre tese e argumento, retomando informações da unidade 3.

\section{Tese e argumento}

Como vimos na Unidade 3, em um texto argumentativo, aquele que escreve apresenta uma tese (a ideia que quer defender) justificando-a com a ajuda de argumentos. Estes argumentos são interligados de maneira lógica à tese que querem justificar. Eles são igualmente ligados uns aos outros:

É preciso incentivar o cinema brasileiro (tese), porque temos produções de excelente qualidade (1‥ argumento) e porque sem 0 incentivo oficial seria esmagado pelas superproduções americanas $\left(2^{\circ}\right.$. argumento).

Neste exemplo, os dois argumentos estão ligados à tese pela conjunção subordinativa "porque" (que exprime a causa), e estão coordenados pela conjunção "e".

Um dos pontos negativos da obra de Maia é o espaço restrito que impõe ao tema da construção de um parágrafo. Assim, o autor não apresenta os diferentes tipos de parágrafos, e tampouco sugere nem condena quaisquer formas de iniciar uma tese. Também não há uma preocupação do autor em chamar a atenção do aluno para a produção textual de vestibular. Há dois exercícios nessa seção que lida com os tópicos da tese e do argumento, ilustrando apenas dois excertos para que os alunos identificassem os argumentos e a tese. Por conta disso, acreditamos que no que tange à produção textual, o professor precisará acrescentar mais informações e até exemplos referentes à elaboração de um texto.

No livro Português: Linguagens, escrito por William Roberto Cereja \& Thereza Cochar Magalhães, aprovado no PNLEM 2009, o texto é concebido como processo 
construído em um contexto interacional, o que remete a um posicionamento sociointeracionista. No entanto o uso do texto como pretexto para a abordagem em sua maioria prescritiva e classificatória de questões fonológicas, morfológicas e sintáticas se opõe à postura sociointeracionista. De modo geral, trata-se de um livro que articula atividades de leitura, produção textual e literatura, priorizando-se os gêneros textuais e suas funções comunicativas.

A obra organiza-se em 9 unidades que se subdividem em 57 capítulos, que abrangem os temas Língua: uso e reflexão, Literatura e Produção de texto. Em geral, os capítulos de produção de texto trazem um material diversificado, tais como ilustrações, gráficos, charges, textos que funcionam como treino inicial para a elaboração de um texto escrito ou oral sobre um tema sempre ligado à realidade do aluno. Será alvo desta pesquisa o capítulo que discute o texto dissertativoargumentativo, tal como veremos a seguir:

\section{Capítulo 53: 0 texto dissertativo-argumentativo}

\section{Trabalhando o gênero}

Nas aulas de produção de textos, tradicionalmente a escola tem trabalhado com um tipo de texto chamado dissertação. Alguns exames de seleção, como os vestibulares e os chamados vestibulinhos para escolas técnicas e para escolas do ensino médio, também exigem a produção de um texto dissertativo.

Dissertar é o mesmo que explanar sobre um tema, desenvolvê-lo. Em princípio, o texto dissertativo não está comprometido com a persuasão, e sim com

a transmissão de conhecimentos. Apesar disso, os temas propostos para o texto dissertativo são quase sempre polêmicos - maioridade penal, desarmamento, violência urbana, meio ambiente, ética. Por essa razão, o que se espera é um texto em que seu autor analise e discuta o 
tema proposto, defenda seu ponto de vista e, às vezes, proponha soluções.

Além disso, a dissertação escolar apresenta uma estrutura formada por três partes convencionais - a tese (ou ideia principal), 0 desenvolvimento e a conclusão -, que coincidem com a estrutura da maior parte dos gêneros argumentativos.

O texto a seguir foi escrito por um candidato no exame vestibular da FUVEST 2007. Leia-o.

\section{A cultura da amizade}

A amizade tem sido eleita por pensadores e artistas de diversos tempos como uma das coisas mais importantes da vida. Há quem lhe atribua importância maior que a do amor.

Em nosso mundo contemporâneo não faltam produções escritas ou audiovisuais que coloquem a amizade no mais alto patamar. Porém, tanto nas produções de tempos passados como nas de tempos atuais, a amizade é tratada como um ideal, no sentido de que é algo difícil de ser obtido.

Na Antiguidade Clássica, Cícero já apontava a existência daqueles que suprimem a amizade de suas vidas ao comentar que os que assim o faziam pareciam-no privar o mundo do sol. Se há um amplo reconhecimento de sua importância, por que a amizade é vista e apresentada como algo difícil e raro?

Montaigne, em suas reflexões, oferece alguns elementos que nos permitem abordar melhor a questão. Ao apresentar a amizade como um tipo de relacionamento no qual se busca uma intimidade sem reservas, Montaigne põe o foco em seu aspecto das relações pessoais que, se foi complexo em seu tempo, seguramente é problemático na sociedade ocidental contemporânea.

É uma característica de seus dias atuais o crescente individualismo, que alguns pensadores preferem qualificar como narcisista. Vive-se em um ambiente no qual, mais do que ser, é preciso parecer. A criação da atividade de consultor de imagem nos dá uma dimensão da separação cada vez maior entre o que efetivamente somos e a imagem que buscamos (ou precisamos) transmitir.

A nossa aparência não busca refletir o que somos mas, em uma inversão de significado da palavra "imagem", é ela quem nos define para os outros. Em tal contexto, como construir intimidade? E, em consequência, como cultivar amizades?

Se tem sido benéfico para o sistema econômico, o individualismo narcisista tem transformado, no plano das relações pessoais, campos aráveis em terras arenosas. 
Milhares de anos atrás, a humanidade foi desafiada e deu uma resposta e um salto qualitativo ao aprender a cultivar a terra. Hoje o novo desafio é colocado e, novamente, a alternativa pode estar no desenvolvimento do cultivo, da cultura da amizade.

(Guia do Estudante - Redação vestibular 2008. São Paulo: Abril, 2008)

Já no início do capítulo há uma apresentação conceitual sobre dissertar, uma breve explicação sobre a estrutura do texto que deve se organizar em tese, desenvolvimento e conclusão e, por fim, há um exemplo de texto escrito por um candidato da FUVEST 2007 o qual foi publicado no Guia do Estudante - Redação Vestibular 2008. Esse texto permite ao aluno inferir que se trata de um texto ideal e que deve seguir esse padrão de qualidade para que seja bem avaliado em um vestibular concorrido como o da FUVEST. Esse exemplo de texto vai ser explorado por meio de exercícios que exigem dos alunos o reconhecimento da estrutura do texto dissertativoargumentativo:

1. O texto dissertativo apresenta três partes essenciais: uma introdução, na qual é exposta a tese ou a ideia principal que resume 0 ponto de vista do autor acerca do tema; 0 desenvolvimento, constituído pelos parágrafos que explicam e fundamentam a tese; e a conclusão. Numere os parágrafos do texto em estudo e identifique:

a) o parágrafo em que é feita a introdução do texto;

b) os parágrafos que constituem o desenvolvimento do texto;

c) o (s) parágrafo (s) de conclusão.

A partir do segundo e do terceiro exercícios, são solicitados, respectivamente, a identificação da tese defendida pelo autor e o reconhecimento do procedimento (comparação, alusão histórica, citação e etc.) adotado para a construção dos 
parágrafos do desenvolvimento a partir da tese exposta no $1^{\circ}$. parágrafo. Na sequência, apresenta-se um exercício em que são definidos os tipos de conclusão, solicitando ao aluno que proceda à a classificação da conclusão do texto que serviu de exemplo. Por fim, os exercícios 5 e 6 tratam das questões de adequação linguística e retomada das características da tipologia dissertativo-argumentativa, respectivamente.

2. Releia o parágrafo em que é feita a introdução do texto. Qual é a tese defendida pelo autor?

3. O desenvolvimento é formado pelos parágrafos que fundamentam a tese. Normalmente em cada parágrafo é apresentado e desenvolvido um argumento. Cada argumento pode ser desenvolvido por meio de procedimentos como:

- Comparação

- Alusão histórica

- Citação

- Exemplificação

- Oposição ou Contraste
- Definição

- Apresentação de dados estatísticos

- Relação de causa e efeito

Reconheça no desenvolvimento do texto o parágrafo em que é feito o uso de:

a) comparação

b) alusão histórica

d) oposição ou contraste

c) citação

e) definição

f) relação de causa e efeito

4- O texto dissertativo-argumentativo faz uso de dois tipos básicos de conclusão: a conclusão-resumo, que retoma as ideias do texto, e a conclusão-sugestão, em que são feitas propostas para a solução de problemas. Que tipo de conclusão o texto em estudo apresenta?

5- Observe a linguagem do texto.

a) Que tempo e modos verbais são predominantes?

b) Qual é a variedade linguística empregada?

c) A linguagem é predominante pessoal ou impessoal? Justifique sua resposta com base na pessoa do discurso, nas formas verbais e nos pronomes empregados. 
d) O texto revela maior preocupação com a expressividade, com a emotividade ou com a precisão das informações?

6- Reúna-se com seus colegas de grupo e,juntos, concluam: Quais são as principais características de um texto dissertativo-argumentativo? Respondam, levando em conta os seguintes critérios: finalidade do gênero, perfil dos interlocutores, suporte/veículo, tema, estrutura e linguagem.

Depois de ser trabalhado o reconhecimento de todas as partes do texto dissertativo, o livro orienta a produção de texto que será elaborado pelo aluno. Para isso, a obra segue o padrão do vestibular, apresentando três excertos (dois textos discursivos e uma charge), a fim de que o aluno colha informações sobre o tema e possa formular uma crítica que será exposta em forma de texto dissertativoargumentativo. Nele, opinará e debaterá o tema, levantando argumentos seguindo as instruções de esquema estrutural: tese, desenvolvimento ( $1^{\circ}$., $2^{\circ}$. e $3^{\circ}$. argumento) e conclusão para a produção de texto.

\section{Produzindo o texto escrito}

Após o debate, planeje o procedimento para a produção de seu texto dissertativo-argumentativo. Para isso, siga estas instruções:

a) Pense em seus leitores. Seu texto poderá ser divulgado no mural ou no jornal de sua escola, num blog ou num fórum de debates da internet, cujos leitores são, na maioria, jovens como você.

b) Organize o texto em parágrafos. Você pode apresentar a ideia principal (a tese) no $1^{\circ}$ ou $2^{\circ}$ parágrafos $e$, nos parágrafos seguintes, os argumentos que a fundamentam. No último parágrafo deve constar a conclusão. Outra possibilidade é estruturar o texto em um esquema, como, por exemplo:
Tese:
Desenvolvimento:
1ำ argumento:
$2^{\circ}$ argumento:
$3^{\circ}$ argumento:
Conclusão: 
c) Empregue a variedade padrão, que é a adequada a esse tipo de texto e a essa situação, e uma linguagem impessoal.

d) Concluído o texto, dê a ele um título interessante e, antes de passá-lo a limpo, faça uma revisão cuidadosa, seguindo as orientações do boxe Avalie seu texto dissertativo-argumentativo.

AVALIE SEU TEXTO DISSERTATIVO-ARGUMENTATIVO
Observe se seu texto apresenta três partes essenciais:
Introdução (com a tese ou ideia central), desenvolvimento e conclusão;
se no desenvolvimento os argumentos fundamentam devidamente o
ponto de vista, estabelecendo relações de causa e efeito ou apoiando-
se em comparações, depoimentos ou citações de pessoas
especializadas no assunto, dados estatísticos, pesquisas, alusões
históricas, etc.; se a linguagem empregada está adequada ao gênero,
ao público e à situação.

Ainda nessa obra, há a unidade 55 tratando do parágrafo do texto dissertativo argumentativo. Essa unidade faz uma abordagem sobre a estrutura e os tipos mais comuns de parágrafos, tais como: declaração inicial, definição, alusão histórica, interrogação, oposição, citação, divisão, exemplificação, detalhamento e ilustração. Vejamos alguns exercícios que desenvolvem o trabalho de estrutura do parágrafo:

\section{Capítulo 55: 0 Texto dissertativo-argumentativo - o parágrafo Trabalhando o gênero}

Leia este parágrafo:

A linguagem é um instrumento eficaz para atingir objetivos em um mundo marcado pela complexidade de relações humanas. Ela nos permite entrar em relação com outras pessoas, trocar informações, expressar afetos e emoções, solicitar o auxílio do outro, levar o outro a agir, influenciá-lo em suas decisões e ações. É através da linguagem que materializamos nossas intenções em relação ao outro. Segundo Peter Drucker, um dos pensadores modernos da administração, $60 \%$ de todos os problemas administrativos resultam de ineficiência e falhas na comunicação. Não só na área empresarial, mas também em todos os outros domínios que demandam relações entre pessoas, a comunicação é importante e sua ineficiência pode causar prejuízos materiais, afetivos e pessoais. 
1. Um texto é normalmente organizado em unidades menores, chamadas parágrafos. Um parágrafo pode ser formado por uma ou mais frases, sendo seu tamanho variável. Quantas frases há no parágrafo em estudo?

2. O parágrafo costuma estruturar-se em torno de uma ideia núcleo, que é desenvolvida por ideias secundárias. No parágrafo em estudos:

a) A ideia-núcleo é apresentada por meio de uma afirmação. Qual é ela?

b) Em que parte do parágrafo se localiza essa afirmação?

c) Em quais frases do parágrafo estão as ideias secundárias?

d) Qual das ideias secundárias apresenta um detalhamento a respeito da linguagem?

e) $\mathrm{Na} 4^{a}$ frase, há uma citação e um dado estatístico. Qual é a função dessa frase no parágrafo?

O livro explica que essas são formas de se produzir um parágrafo, não necessariamente é a forma de se defender uma tese, diferentemente da obra Roteiro de redação - lendo e argumentando, coordenada por Antonio Carlos Viana (1998), que apresenta os tipos de parágrafos como formas de iniciar um texto, conforme já expusemos na seção 3.2. Observemos o seguinte quadro, extraído da obra de Cereja \& Cochar Magalhães:

\section{Nem camisa de força nem lugar-comum}

Embora existam modelos rígidos de estruturação de parágrafos e de textos dissertativo-argumentativo, eles devem ser tomados apenas como referência, e não como uma camisa-de-força.

Ao escrever, deve-se relativizar o uso desses modelos, adequando-os às especificidades de cada texto, e acrescentar a eles novos elementos, inspirados na criatividade e nos estilo pessoal.

Ao mesmo tempo, deve-se evitar iniciar o parágrafo com lugarescomuns como "Desde os primórdios da humanidade", "No mundo em que vivemos", "Nos dias de hoje", "Na atualidade", etc.

Nele, o título remete a elaborações que não devem ser tão rígidas, no entanto deve-se evitar o início de parágrafos com lugares-comuns, tais como "Desde os 
primórdios da humanidade", "no mundo em que vivemos", "nos dias de hoje", "na atualidade" e etc. Se, mesmo diante destas orientações, essas são as estruturas mais utilizadas pelos alunos, ratifica-se a hipótese de que em um momento de tensão é em estrutura como essas que os alunos se sentem seguros para iniciar uma produção textual.

A obra de Ulisses Infante, Textos: Leituras e Escritas - volume único, assume uma perspectiva interacionista e organiza-se em 32 unidades, que versam sobre Literatura, Língua e Produção de Textos. Só para o tema Dissertação e textos dissertativos o livro apresenta 5 unidades. Na primeira delas, Infante expõe o que é o ato de dissertar, partindo de situações do cotidiano numa abordagem mais linguística:

“(...) Com frequência, precisamos deixar claro às pessoas com quem convivemos o que pensamos sobre determinado assunto. Em alguns casos, é necessário persuadi-las a adotar ou aceitar a nossa forma de pensar. Reflita: isso ocorre em seu relacionamento amoroso, em sua convivência diária com os amigos e familiares, na sua relação com professores, vizinhos, etc. Em todas essas situações e em muitas outras, somos levados a utilizar a linguagem para dissertar, ou seja, organizamos palavras, frases, textos, a fim de, por meio da apresentação de ideias, dados e conceitos, chegarmos a conclusões."

$(\ldots)$

"É a atitude linguística da dissertação que nos permite fazer uso da linguagem a fim de expor ideias, desenvolver raciocínios, encadear argumentos, atingir conclusões. Os textos dissertativos são produto dessa atitude e participam ativamente do nosso cotidiano falado e escrito (...)."

Em seguida, em uma subseção da unidade, intitulada de "Para escrever o texto dissertativo", a obra apresenta cada uma das partes estruturantes da dissertação 
(introdução, desenvolvimento e conclusão). Vejamos o que o autor apresenta acerca do parágrafo tese:

\begin{abstract}
Introdução - é o ponto de partida do texto. Por isso, deve apresentar de maneira clara o assunto tratado e também delimitar as questões referentes a esse assunto que serão abordadas. Dessa forma, a introdução encaminha o leitor, estabelecendo para ele a orientação adotada para o desenvolvimento do texto. Atua, assim, como uma espécie de "roteiro".

Ao preparar a introdução do seu texto, você pode utilizar recursos que despertem o interesse do leitor: formular uma tese, que deverá ser discutida e provada pelo texto; lançar uma afirmação surpreendente, que o corpo do texto tratará de justificar ou refutar; propor uma pergunta, cuja resposta será dada no desenvolvimento e explicitada na conclusão.
\end{abstract}

Após apresentar a estrutura organizacional do texto dissertativo, na subseção Prática de língua falada, são propostas atividades em grupo para que os alunos possam construir a capacidade argumentativa por meio de debates e confronto de opiniões e ideias. Posteriormente, é apresentado um artigo de revista que será explorado por meio de exercícios, cujo objetivo é fazer com que o aluno reconheça as partes de uma dissertação e, especialmente, os argumentos apresentados. Orienta também a prática de interpretação textual.

As outras quatro unidades sobre o tema dissertação evidenciam mais exemplos, integrando-os a aspectos, tais como coesão e coerência. Essas atividades permitiriam o desenvolvimento da proficiência em leitura e colaborariam para a construção de sentidos do texto. Outro ponto positivo da obra de Infante é que os temas dos textos 
motivadores, além de darem conta do universo cultural do estudante de ensino médio, favorecem a articulação das atividades de leitura e de produção textual.

Admitimos que obras como a de Infante e a de Cereja e Cochar exploram mais o texto argumentativo, seja com exemplos seja com exercícios. No caso de Cereja e Cochar, percebemos que os autores estigmatizam termos como "Desde os primórdios", "Nos dias de hoje", dentre outros.

Diante disso, se ainda assim os alunos recorrem, com grande frequência, a esses termos; é fato que orientar para o não uso dessas expressões não impedirá o uso delas. Aliás, se mesmo diante da informação, os candidatos continuam usando, é sinal de que no momento de tensão é muito mais significativo apresentar na tese um espaço que para o candidato é seguro, do que tentar construir um novo alicerce, que provoca insegurança, para produzir seu texto.

A obra do autor Maia, pelo excesso de objetividade e por expor exercícios de pouca complexidade, não favorece grandes resultados para a aprendizagem do aluno, no que tange à elaboração de uma tese. Esse livro também não tece comentários eficientes que auxiliem o aluno na elaboração de textos.

Por fim, apesar dos livros analisados apresentarem contribuições diferentes para a aprendizagem da produção textual; em suma, todos eles pouco contribuíram para a aprendizagem do aluno quanto à construção da tese, ficando a cargo da escola (especialmente, o professor de português). 


\title{
CONCLUSÃO
}

\author{
"Iniciar uma tese é difícil. Concluir uma tese \\ é ingrato, porque o tempo não para. No \\ entanto, o tempo não impede que toda \\ pesquisa um dia possa continuar"
}

Renata Barbosa Vicente

Como pudemos evidenciar no capítulo de análise de dados, algumas estratégias guiam nossa mente na construção do primeiro parágrafo de um texto. Há graus de complexidade envolvidos na decisão do que pode compor esse momento de chegada para a interação. Portanto, é compreensível a impressão compartilhada pelos alunos: começar a redação é uma das tarefas mais complicadas ao se elaborar uma dissertação. Nesses quatro anos de estudo, pudemos investigar cada questão que envolvia essa tarefa orientados pelas hipóteses expostas durante os capítulos 1 e 2 .

Para elaborar esta conclusão, notamos a mesma estratégia e preocupação de todo escrevente presente na topicalização apresentada. Para dar início ao texto da conclusão, embora tenhamos todo o conteúdo a expor e sabermos o que exatamente deve compor este texto porque já viemos dialogando sobre o tema no decorrer de alguns capítulos, ainda assim foi necessário criar o espaço conjunto de atenção, ou seja, precisamos manter viva a "impressão" de que estamos conectados, sintonizados, a despeito de mudar o capítulo. Foi a meta cumprida pela informação "Como pudemos 
evidenciar no capítulo de análise de dados [...]", que simulou a retomada dialógica típica: "como estava dizendo".

O lugar seguro onde iniciamos uma interação altamente complexa, como é o caso da escrita formal, continua sendo a estratégia comum e regular de interações menos complexas, porém revestida de elementos que simulam um espaço de maior complexidade. Outras complexas tarefas envolvem a redação dissertativa, dentre as quais figura a leitura dos excertos do tema, pois entendemos que a reflexão sobre o processamento textual tem início já no momento da leitura da proposta do texto. Durante esse momento, o escrevente procede a pequenos cortes que funcionam como entradas a partir das quais elaboram hipóteses de interpretação. Esse processamento textual é empreendido com base no conhecimento gramatical e lexical, no conhecimento sobre o mundo, bem como conhecimentos alusivos a vivências pessoais e eventos espácio - temporalmente situados e, por fim, no conhecimento das formas de interação por meio da linguagem. Entendemos que esses conhecimentos contribuem para a formulação das primeiras palavras do texto.

$\mathrm{Na}$ construção do parágrafo introdutório, muitos fatores interferem. Alguns deles estão os que afetam diretamente a produção textual na segunda fase da FUVEST. Citemos a própria tensão do momento, , a maturação e preparo na tarefa de escrever dissertações e o domínio linguístico e das normas gramaticais.

Esse contexto de produção conduz o candidato à intenção de produzir o melhor texto que pode, porém com as ferramentas linguísticas e repertório de leitura 
disponíveis e construídos durante sua formação escolar. Nesse sentido, nem sempre o que o candidato possui está a altura da concorrência.

Ademais, a redação soma pontos significativos para quem deseja uma aprovação em uma das maiores e mais concorridas universidades do país. Diante desse quadro de exigência, os candidatos saem em busca da gramática perfeita e da busca pelo texto estruturalmente perfeito. É com essa intenção, em alto de grau de consciência sobre o próprio fazer, que abrem seus textos.

Para tratar de consciência, tema polêmico na escrita, recorremos a Damásio, neurocientista que apresenta resultados consideravelmente substanciais no meio científico, mas que ainda pede um exame na área de produção linguística. Nesta pesquisa, estabelecemos uma conexão entre os estágios de self, postulados pelo autor, e a mobilização de conhecimentos do repertório discursivo-pragmático para o resultado produtivo na redação de vestibular, pois é na produção textual que encontramos mecanismos linguísticos capazes de denunciar o estágio evolutivo da mente.

Com base na análise dos dados, pudemos concluir que os textos apresentam gradiência de cultura e isso se relaciona com os três estágios dos selves. Quanto mais o indivíduo demonstra cultura e habilidade em produzir um texto, mais avançado é o estágio evolutivo da mente nas tarefas que envolvem língua escrita formal. Num estágio de self autobiográfico, o indivíduo desliga-se de heranças socioculturais (típicas de protosself), afasta-se de metáforas que são produtivas e as adapta a novos contextos, para codificar a subjetividade. 
Em sintonia com Damásio e após a análise dos textos, podemos afirmar que somos um self em adaptação continuamente. Quanto mais nos adaptarmos aos padrões, mais condições e oportunidades melhores teremos de sobrevivermos no mundo da escrita e alcançar objetivos. É o que faz o self autobiográfico: luta pelo sucesso de seu empreendimento linguístico na língua escrita. A concentração é o que a sociedade cobra do aluno ou candidato a vestibulares que pretende passar, mas o que ele tem a oferecer é a vigília, que também é treinada cotidianamente na escola.

Sentimentos provocam consequências devastadoras nos candidatos. Em ambos, impactam qualitativamente a linguagem e a língua, daí a iconicidade que percebemos. Evocações são típicas de self autobiográfico, porque, inclusive, trazem o enriquecimento textual com citações altamente contextualizadas.

Retomando Damásio (2011, p. 263) e dialogando com os resultados alcançados, podemos afirmar ainda que:

(i) os conjuntos de memórias biográficas são agrupados sem filtros culturais pelo protosself;

(ii) objetos (propostas) podem afetar o protosself e produzir pulsos, manifestados em termos de encaixamento padronizado pelo self central; e

(iii) mecanismos coordenadores de evocações de memórias interagem com o self central, resultando em linguagem autobiográfica, linguagem que representa intenções do ser. 
Essas constatações licenciam afirmar que é possível que a linguagem assim como a língua denunciam graus de consciência. O que aperfeiçoaria um self central é uma questão didático-pedagógica interessante: o exercício contínuo de modelos e padrões conjugado a experienciamentos de cultura. Essa explicação tem amparo nos movimentos ontogênicos e filogênicos de adaptação: só fazemos melhor o que fazemos cotidianamente.

Reconhecemos que o vestibular é uma situação de tensão e de emoções básicas vivenciadas pela espécie que são codificadas no cérebro. Em virtude desse contexto, originam-se de comandos dessa região as respostas biofísicas, por exemplo, sudorese, dor na mão e esquecimentos. Especialmente, no caso de esquecimentos, "os famosos brancos", temos um exemplo de resposta biofísica que nos permite concluir que as emoções interferem na linguagem, o que garante a ideia de que as emoções podem ser codificadas via sintaxe.

Esta pesquisa também permitiu perceber que é próprio do ser humano, numa interação face a face, procurar estabelecer um contato utilizando basicamente os mesmos enunciados, de geração a geração, o que revela uma aprendizagem por imitação. Na produção escrita, não foi diferente, a identificação de 7 padrões, já resumidamente reapresentados nesta seção, demonstrou que o candidato se sente seguro usando de uma situação já conhecida ou similar para atuar na nova situação.

Todos nós aprendemos por imitação, aos termos contatos com textos do dia a dia, ou mesmo com os exemplos do livro didático. Com o exercício inspirado em 
modelos, passamos a reproduzi-los com base naquilo que já conhecemos, que nos serve de parâmetro para novas produções de um texto.

Ao estabelecermos um diálogo entre cognição e linguagem, pudemos relacionar os padrões identificados aos estágios evolutivos da mente. Foi a partir daí que a divisão das redações entre melhores e piores revelou-se neutralizada nesta tese. $\mathrm{Na}$ verdade, o que diferencia a produção desses dois blocos são as experiências vivenciadas de caráter cultural, representadas por vários aspectos entre os quais a formação escolar.

Analisamos os dados introdutórios das dissertações e evidenciamos existir alta correlação entre mobilização de informações da bagagem ou repertório discursivopragmático e complexidade demandada pelo background. Esses resultados nos levaram a formalizar um continuum de categorizações cognitivas subjacentes aos usos. Compulsoriamente, verificamos que o princípio da unidirecionalidade contribui para compreender as diferentes estruturas introdutórias, e que, no entanto, esse fenômeno não passa, necessariamente, por todas as categorias cognitivas. Essa linha unidirecional permitiu compreender que as mudanças são operadas da esquerda para a direita e, nesse caso, de categorias menos complexas, [-abstratas], para categorias cognitivas mais complexas [+ abstratas].

Como já vínhamos estudando há pelo menos oito anos, é certo que a gramaticalização constitui-se um processo dinâmico que reflete não somente o movimento contínuo da estrutura, mas ainda uma atividade cognitiva com reflexos na própria estrutura. Evidenciamos, nesta tese, que há um forte diálogo entre os 
pressupostos de gramaticalização (Heine, Claudi e Hünnemeyer, 1991), e manifestação de selves.

Também concluímos que as intenções textuais, seja a de conversar, de dissertar ou mesmo a de dissertar mostrando que sabe dissertar em níveis de atenção e de consciência distintos sobre o fazer linguístico. Essas codificações, que representam um sistema linguístico, são impactadas pela ansiedade.

Mesmo os indivíduos que demonstram resiliência a situações de ansiedade são seres comuns que aprenderam a produzir em si um significado adaptativo e 'evolutivo'. Dessa forma, o sistema linguístico evolui à custa de adaptação, assim como o fazer dissertativo também é uma questão de evolução do grau de atenção e de consciência do self.

Ainda nesse sentido, o indivíduo resiliente, em uma situação de maior tensão, como é o caso de produzir uma dissertação de vestibular, demonstra maior controle sobre a situação e apresenta um resultado motor, físico e psicológico ou mental menos agressivo a si. Tudo isso é canalizado pelo sistema linguístico, que, por sua vez, é apreendido nos usos ou em situações formais proporcionadas pela escola e pelos cursinhos pré-vestibulares.

A experiência de produzir um texto dissertativo pode até ser conhecida pelo candidato, no entanto o tema é sempre um elemento não conhecido, o que torna essa experiência nova. Por isso, sensações, emoções e até mesmo intenções de defesa, de abordagem, de agressividade, por exemplo, são carreadas nessa nova situação. Se 
não tiver domínio do novo ambiente de experienciamento, ainda que a experiência já seja conhecida, o candidato usa um frame, um enquadre conhecido para resolver a nova situação, daí o fato de tanto as redações "melhores" quanto "piores" refletirem coincidência na distribuição de categorias cognitivas mobilizadas para a construção do primeiro parágrafo, a categoria de espaço. É nessa categoria que o candidato encontra o enquadre seguro para iniciar uma tese.

Para compreendermos o porquê de o indivíduo basear-se em uma cena já conhecida para atuar em nova situação, buscamos a resposta na neurociência. Esta ciência contribuiu para entendermos que o ser humano é uma espécie analógica por natureza (DEL NERO, 1997) e que, na busca por longevidade, adapta-se continuamente. Assim, o habitual é remanejado em funções. Conversar transforma-se em interagir na escrita, mas as adaptações são feitas à custa de alto grau de atenção e de consciência. Essa é uma adaptação que exige um processo paulatino, lento e gradual.

Analisando as redações que compõem o corpus de 2004 a 2011 e descrevendo os usos introdutórios dessas, notamos o alto índice de ocorrências de expressões circunstanciais, como as de lugar e de tempo. Expressões como "na sociedade moderna" e "o Brasil" nos levou a revisitar os dados e perceber as categorias cognitivas organizadas por Heine, Claudi e Hünnemeyer (1991) não davam conta de classificar esses termos. Essas categorias organizavam-se pelos autores da seguinte forma: pessoa $>$ objeto $>$ espaço $>$ tempo $>$ qualidade.

O problema se consubstanciava no fato de que a categoria espaço equivalia, no 
modelo da gramaticalização, a espaço físico (lugar). Contudo, numa análise mais detida das redações, verificamos que os escreventes não concebiam espaço como equivalente a lugar somente. O lugar seguro para iniciar a tese trazia lugar, mas também trazia espaços mesclados de lugar e tempo, numa combinação ultra-abstrata. Portanto estávamos tratando de categorias diferentes e com graus diferentes de abstratização. Derivam dessas reflexões e análises os seguintes conceitos:

(i) Lugar: localização geográfica;

(ii) Tempo: duração relativa das coisas que cria no ser humano a ideia de presente, passado e futuro; período contínuo no qual os eventos se sucedem;

(iii) Espaço: extensão abstrata, indefinida, de significado subjetivo, ou ainda o resultado da mescla de lugar e tempo.

Por conta disso, o continuum foi reconfigurado e ganhou nova ordenação: pessoa > objeto $>$ processo $>$ lugar $>$ tempo $>$ espaço $>$ qualidade, sempre sendo operadas e em graus de abstratização crescentes da esquerda para a direita.

Percebemos que há um longo hiato entre as categorias cognitivas lugar, tempo e espaço. Embora as estruturas introdutórias sejam nelas agrupadas pelos seus padrões característicos, reconhecemos que elas podem se apresentar, devido ao seu grau de complexidade que reflete o grau de desenvolvimento da mente humana, em padrões mais próximos de uma ou de outra categoria cognitiva.

Influenciados por tais indagações, intuímos que isso venha de suas raízes 
dialógicas, o que na situação de produção de texto equivaleria às regras habituadas durante o comportamento escolar em língua portuguesa: regras gramaticais e formas textuais. Alguns desses padrões espaciais podem assumir um estatuto de chunking, mas esse estatuto é construído de modo subjacente por meio de categorias cognitivas: tempo + lugar = espaço. $\mathrm{E}$ o espaço de consciência na mobilização de repertório cultural encontra em Damásio seu paralelo: protosself + espaço selfcentral = espaço autobiográfico.

Essa mescla depende de uma memória rica, fundamental para que padrões se manifestem, pois uma alta frequência pode conduzir à mudança do padrão, via analogia. Então, os padrões que extraímos, embora provenham de contextos diversos, revelam regularidades que garantem a função prevista.

Categorizar esses padrões, portanto, como fazemos nesta tese, pode ser uma contribuição, cuja utilidade pode se estender também aos ambientes didáticopedagógicos, pois o experienciamento de usos compartilhados socialmente ampliam leques de possibilidades para o uso textual. Ao mesmo tempo, construções linguísticas carreiam fortes aspectos pragmáticos que só ganham corpo verdadeiramente quando a consciência linguística alcança o nível autobiográfico.

A partir da identificação dos processamentos textuais representados no parágrafo inicial, procedemos à organização dos padrões de usos dos candidatos:

Padrão 1: Construção espacial de definição codificada por meio de construção equativa, em cuja conexão de duas orações com estrutura similar está o 
predicador legítimo, um verbo de ligação. O sujeito oracional é um sintagma nominal genérico e abstrato, categorizado como sujeito atípico.

Padrão 2: Construção espacial consubstanciada pela presença de sujeito animado, humano, mais básico, porém mais específico,

Padrão 3: Espaço topicalizado concretizado por uma expressão circunstancial de caráter genérico, que, num modelo funcionalista, atua como satélite da sentença.

Padrão 4: Espaço topicalizado avaliativo em que o candidato constrói um espaço de atenção conjunta específico e localizado, nele elabora um relato circunstanciado ou enumerativo.

Padrão 5: Espaço de reflexão, em que o candidato, sintaticamente, recorre a sujeitos compostos inseridos em uma estrutura afirmativa. Elaborar a tese a partir de uma constatação.

Padrão 6: O espaço intertextual caracteriza-se pela influência de informações que foram associadas pelo escrevente.

Padrão 7: O espaço da dúvida é elaborado a partir de um espaço conjunto que elimina a responsabilidade de uma afirmação incerta feita pelo autor do texto.

Tais padrões remetem a estratégias de aproximação interativas utilizadas para iniciar o tema. Elas são o lugar seguro de ponto de partida do texto e preveem o compartilhamento do interesse de atingir uma boa nota e, consequentemente, alcançar a aprovação em um dos principais vestibulares do país. 
Torna-se importante esclarecer que elaborar uma introdução vai além da materialização desses padrões de escrita. Elaborar uma introdução envolve mente > mente consciente $>$ mente consciente capaz de produzir cultura. Esse estado de vigília diferenciado remete, por sua vez, a estágios evolutivos da mente: protosself $>$ self central > self autobiográfico. Portanto, em consonância com as descobertas de Damásio (2011), identificamos um correlato na construção da tese em dissertações vestibulares:

(i) o protosself corresponde às bases biofísicas do indivíduo, mas também à mobilização básica das ações, tal como é o momento de agir num contexto comum a todos os seres humanos: o de interagir face a face, o de falar em ausência e o de cooperar em situações diversas. Na redação, o candidato coopera, ainda que não tenha a bagagem necessária para cooperar adequadamente. Num nível mais básico de consciência, ele traz exemplos de sua vida, experiência de conversas e não consegue se afastar de si.

(ii) o self central corresponde ao contato do protosself com o objeto, que é a proposta nos casos analisados (ou com o tema da proposta). A partir desse contato, ele emprega o modelo treinado e aprendido num plano de interação que não deixa ver, ainda, sua contribuição autoral.

(iii) o self autobiográfico corresponde à adaptação do modelo para um fim específico, que é o objetivo do instrumento. Mas não somente isso, com um nível de vigília tão alto que adicionalmente mobiliza sua bagagem discursivo- 
pragmática, evidenciando que domina e que merece a nota. Os selves, sob o ponto de vista de nossa proposta, podem ser sintetizados no seguinte esquema:

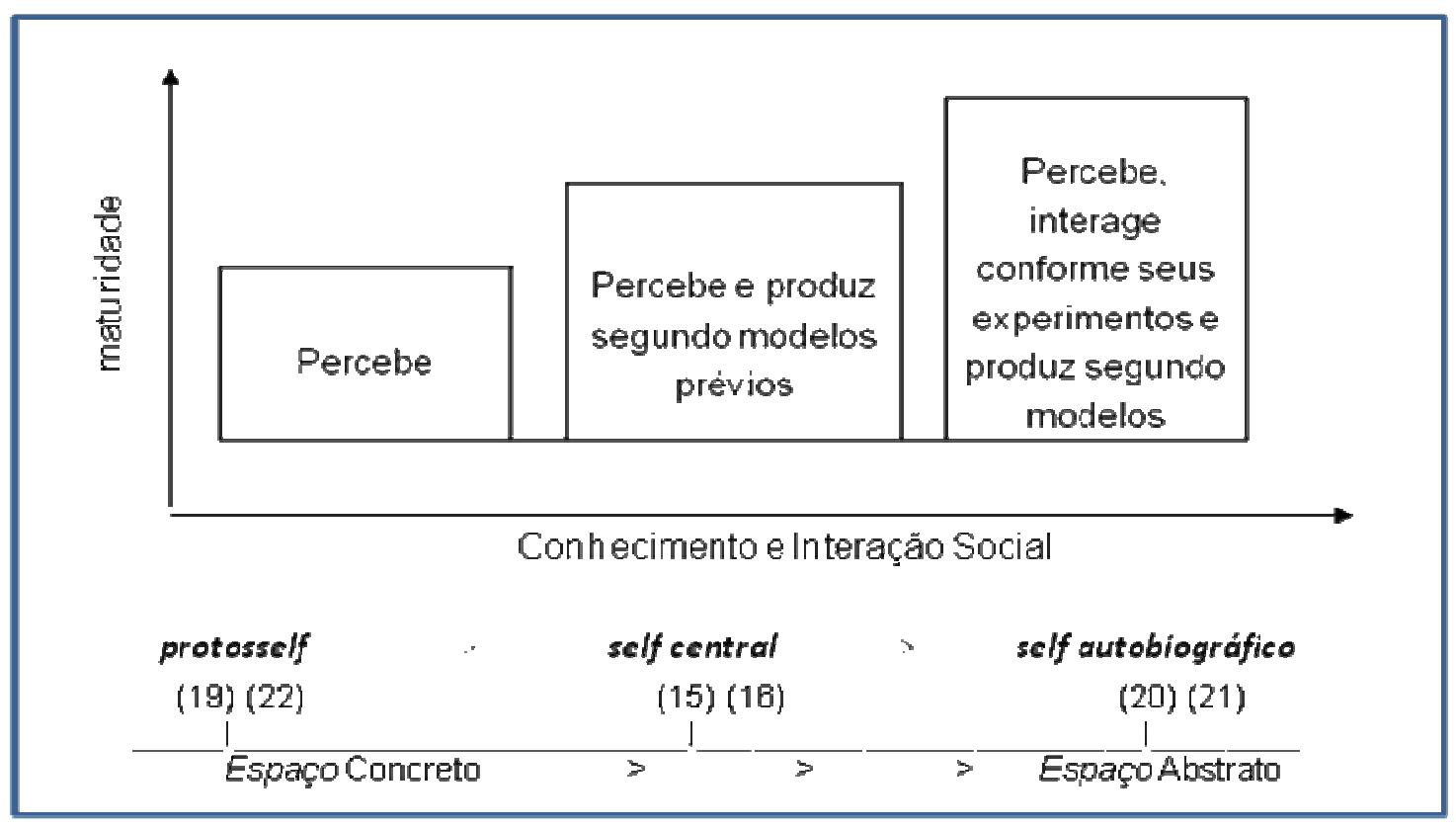

Quadro 11: Gradação da complexidade espacial

Por fim, estas correspondências entre evolução do self, dependente de vivência sociocultural, e evolução da escrita dissertativa mais madura, dependente de exercício contínuo inspirado em modelos. 


\section{Referências Bibliográficas:}

BARROSO, Paulo Henrique. A interface entre Gramaticalização e os Gêneros do Discurso: o verbo BUSCAR no português brasileiro culto.São Paulo, 2008. Dissertação ( Mestrado Filologia e Língua Portuguesa) - USP.

BECHARA, Evanildo. Moderna Gramática Portuguesa, $37^{a}$ edição revista e ampliada, RJ, Editora Lucerda, 1999.

BERNARDO, Kelly Viviane. Estruturas serializadas no português do Brasil: a gramaticalização de vir e virar e sua identificação como verbo serial.Dissertação (Mestrado em Filologia e Língua Portuguesa) - Faculdade de Filosofia, Letras e Ciências Humanas, Universidade de São Paulo, São Paulo, 2008. Disponível em: <http://www.teses.usp.br/teses/disponiveis/8/8142/tde-03122008-154909/>. Acesso em: 2012-05-29.

BRANDÃO, Marcus Lira. As bases biológicas do comportamento: Introdução à neurociência. São Paulo: EPU - Editora Pedagogica e Universitária, 2004.

BYBEE, Joan. Language, usage and cognition. Cambridge: University Press, 2010.

BYBEE, Joan. Mechanisms of Change in Grammaticalization: the role of frequency. In: (pp. 602-623). www.unm.edu/ jbybee, 2003.

CABRAL, Leonor Scliar. Linguagem e Cognição no Processamento Verbal. In MIRANDA, Neusa Salim e NAME, Maria Cristina (Orgs.) Linguística e Cognição. Juiz de Fora: Ed. UFJF, 2005.

CAMPBELL, L. \& JANDA, R. Conception of grammaticalization and their problems. In: Language Science. Columbus: The Ohio State University, 2001.

CASSEB-GALVÃO, Vânia Cristina. Evidencialidade e gramaticalização no português do Brasil: os usos da expressão "diz que". Tese de Doutorado. UNESP, 2001.

CASSEB-GALVÃO, Vânia Cristina. O "achar" no Português do Brasil:um caso de gramaticalização. Dissertação de Mestrado. UNICAMP, 1999. 
CASTILHO, Ataliba Teixeira de. Proposta funcionalista de mudança linguística: os processos de lexicalização, semanticização, discursivização e gramaticalização na constituição das línguas. In: Tânia Lobo; Ilza Ribeiro; Zenaide Carneiro. (Org.). Para a História do Português Brasileiro. Novos dados, novas análises. 1a. ed. Salvador: Editora da Universidade Federal da Bahia, v. 6 (1), 2006.

CROFT, Willian, Toward a Social Cognitive linguistics. In: EVANS, Vyvyan; POURCEL, Stéphanie (Eds). New Directions in Cognitive Linguistics, 2009

CUNHA, Celso, CINTRA, Luís F. Lindley, Nova Gramática do Português Contemporâneo. $3^{\text {a }}$ edição, RJ, Nova Fronteira, 2001

CUNHA, Maria Angélica Furtado da; OLIVEIRA, Mariângela Rios de; MARTELOTTA, Mário Eduardo. Linguística Funcional - teoria e prática. FAPERJ. Rio de Janeiro: DP \&A Editora, 2003.

DAMÁSIO, António R. E o cérebro criou o homem; tradução Laura Teixeira Motta São Paulo: Companhia das Letras, 2011 [2009].

DEFENDI, Cristina Lopomo. "Portanto, conclui-se que": processos de conclusão em textos argumentativos. 2013. Tese (Doutorado em Filologia e Língua Portuguesa) - Faculdade de Filosofia, Letras e Ciências Humanas, Universidade de São Paulo, São Paulo, 2013. Disponível em: <http://www.teses.usp.br/teses/disponiveis/8/8142/tde06052013-104720/>. Acesso em: 2013-11-03.

DEFENDI, Cristina Lopomo. A reduplicação no português culto falado em São Paulo: possível gramaticalização? Dissertação de Mestrado, São Paulo: USP, 2008.

DEL NERO, H. S. O Sítio da Mente: Pensamento, Emoção e Vontade no Cérebro Humano. São Paulo. Editora Collegium Cognitio, 1997.

DIAS, N. B. . As Cláusulas de Finalidade. Campinas, 2001. Tese de Doutorado UNICAMP

DIK, Simon C. The theory of functional grammar. Edited by Kees Hengeveld. Berlin, New York: Mounton de Gruyter, 1997.

FERRARI, Lilian. Introdução à Linguística Cognitiva. S.P.: Contexto, 2011.

FRIED, Mirjam. Principles of constructional change. In TROUSDALE \& Thomas HOFFMANN (eds.) The Oxford handbook of Grammar. Oxfor UniversityPress. Final Draft.

FUVEST, Fundação Universitária para o Vestibular. Fuvest 2010, redações. Algumas das 100 piores e $\mathbf{1 0 0}$ melhores notas. São Paulo, 2010. 
GARCIA, Othon M. Comunicação em prosa moderna - aprenda a escrever, aprendendo a pensar. (10ªed.) Rio de Janeiro: Fundação Getúlio Vargas, 1982.

GIVÓN, T. (1979) On Understanding Grammar. New York: Academic Press

GONÇALVES, Sebastião Carlos Leite. Gramaticalização, modalidade epistêmica e evidencialidade: um estudo de caso no português do Brasil. Campinas, 2003. Tese de Doutorado - UNICAMP

GONÇALVES, Sebastião Carlos Leite; LIMA-HERNANDES, Maria Célia \& CASSEBGALVÃO, Vânia Cristina. Introdução à Gramaticalização: princípios teóricos e aplicação. São Paulo: Parábola Editorial, 2007.

HEINE, Bernd et alii. Grammaticalization: a Conceptual Framework. Chicago: The University of Chicago Press, 1991.

HOUAISS, Antonio, \& VILLAR, Mauro de Salles. Dicionário Houaiss da Língua Portuguesa, Rio de Janeiro: Objetiva, 2001.

JANDA, R.; JOSEPH, B. (eds.) The handbook of historical linguistics. Oxford: Blackwell

KLEINMAN, A ; LAFER, B. ; CAETANO, S. C. . Transtorno bipolar na infância e na adolescência. In: Flavio Kapczinski; João Quevedo e colaboradores. (Org.). Transtorno Bipolar, Teoria e Clínica. 1a.ed.: , 2008, v. , p. 306-330.

$\mathrm{KOCH}$, Ingedore Villaça e ELIAS, Vanda Maria. Ler e compreender - os sentidos do texto. (2ª ed.) São Paulo: Contexto, 2010.

$\mathrm{KOCH}$, Ingedore Villaça. Desvendando os segredos do texto. São Paulo: Cortez, 2002.

LANGACKER, R. Foundations of cognitive Grammar: Theoretical prerequisites. Standford: Stanford University Press, 1987.

LIMA-HERNANDES, M.C. Processos Sociocognitivos da Mudança Gramatical: Estrutura x-que do português. Tese de livre docência. São Paulo: FFLCH, 2010.

LIMA-HERNANDES, Maria Célia (Org.). Gramaticalização em perspectiva: Cognição, textualidade e ensino. São Paulo: Paulistana, 2010b.

LIMA-HERNANDES, Maria Célia. A interface Sociolinguística/Gramaticalização Estratificação de usos de tipo, feito, igual e como - sincronia e diacronia. Tese de doutoramento. Campinas: IEL/UNICAMP, 2005. 
LIMA-HERNANDES, Maria Célia. Neogramáticos, sim, mas com toda a gradiência... Revista do Gel. São Paulo, v.7, n.1, p.57-70, 2010c. Disponível em http://pt.scribd.com/doc/59671959/4/Maria-Celia-LIMA-HERNANDES1. Acesso em 22 nov. 2011.

MAIA, João Domingues. Português (ensino médio). São Paulo: Ática, 2002.

MARTELOTTA, Mário Eduardo et alii. (1996). Gramaticalização no português do Brasil: uma abordagem funcional. Rio de Janeiro: Tempo Brasileiro.

MATURANA, Humberto R. e VARELA, Francisco J. A árvore do conhecimento: as bases biológicas da compreensão humana. Tradução Humberto Mariotti e Lia Diskin; ilustração: Carolina Vial, Eduardo Osório, Francisco Olivares e Marcelo Maturana Montañez - São Paulo: Palas Athena, 2001 [1984].

MEYER, Philippe. O olho e o cérebro: biofilosofia da percepção visual; tradução Roberto Leal Ferreira. São Paulo: Editora UNESP, 2002 [1997].

MITHEN, Steven. A pré-história da mente: uma busca das origens da arte, da religião e da ciência. Tradução Laura Cardellini Barbosa de Oliveira. São Paulo: Editora da Unesp, 2002 [1996].

MOLLICA, Maria Cecília (org.) - CLA Cadernos Didáticos UFRJ - Introdução À Sociolinguística Variacionista. 3ª edição, 1996

NEVES, M.. H. M. ; BRAGA, M. L. ; Dal'Aglio-Hattnher, Marize . As Construçòes Hipotáticas. In: Moura Neves, Maria Helena; DalÁglio-Hhattnher, Marize. (Org.). Gramática do Português Culto Falado no Brasil. Classes de Palavras e Processos de Construção. 1 ed. Campinas: Editora da Unicamp, 2009, v. 2, p. 937-1015.

NEVES, Maria Helena de Moura, Gramática de usos do português - $3^{\underline{a}}$ reimpressão, São Paulo: Editora UNESP, 2000.

NEVES, Maria Helena de Moura. A gramática funcional. São Paulo: Martins Fontes, 1997.

PINKER, Pinker. Do que é feito o pensamento: A língua como janela para natureza humana.; tradução Fernanda Ravagnani. 1a Ed. - São Paulo: Companhia das Letras, 2008 [2007].

SARTIN, Elisângela Baptista de Godoy, Gramaticalização orações para mais infinitivo no Português do Brasil. Dissertação de Mestrado. SP. 2008. 
SCHUTZ, A. Foundations of a Theory of Intersubjective Understanding. In: The phenomenology of the social world. Evanston, IL. Nortwestern University Press, 1967.

SPAZIANI, Lídia, A gramaticalização do item fora no Português do Brasil: a unidirecionalidade do processo. Dissertação de Mestrado. SP. 2008.

TAYLOR, John R. Cognitive Grammar. United States: Oxford University Press, 2002.

TOMASELLO, Michael. The cultural origins of human cognition. Cambridge/Massachusetts: Harvard University Press, 2003[2000].

TRAUGOTT, Elizabeth Closs. Pragmatic strengthening and grammaticalization. In: AXMAKER, Shelley; JESSIER, Annie; SINGMASTER, Helen (orgs.) General Session and Parasession on Grammaticalization. Berkeley Linguistics Society, 1988.

VICENTE, Renata Barbosa. Mudança Gramatical da Palavra AFINAL e sua gramaticalização num contraste entre variedades lingüísticas: Português do Brasil e de Portugal. Dissertação de Mestrado. 2009

VOSSLER,Karl. Filosofía del lenguaje. Buenos Aires: Editorial Losada, 1944[1923]. [Tradução de Amado Alonso e Raimundo Lida.]

\section{Referências Internet}

http://g1.globo.com/vestibular-e-educacao/noticia/2011/12/veja-dez-aulas-com-dicas-

para-fazer-redacao-do-vestibular-da-fuvest.html

http://www.fuvest.br/vest2004/provas/2fase/por/por2f.pdf

http://www.fuvest.br/vest2005/provas/2fase/por/por2f.pdf

http://www.fuvest.br/vest2006/provas/2fase/por/por2f.pdf

http://www.fuvest.br/vest2007/provas/2fase/por/por2f.pdf

http://www.fuvest.br/vest2008/provas/2fase/por/por2f2008.pdf

http://www.fuvest.br/vest2009/provas/2fase/por/por2f2009.pdf

http://www.fuvest.br/vest2010/provas/fuv2010_2fase_prova1.pdf

http://www.elitecampinas.com.br/gabaritos/fuvest/2011/Elite Resolve Fuvest 2fase 20

11-Portugues.pdf 
http://www.charliechaplin.com/en/films/6-modern-times 
ANEXO I

1. Efeito Borboleta (Butterfly Effect, 2004): Ashton Kutcher é um estudante de psicologia que sofreu diversos traumas de infância e descobre ter o poder de viajar no tempo ao ler o seu antigo diário. Ao tentar "consertar" o passado, cria situações catastróficas no futuro. Uma espécie de De Volta Para o Futuro do lado negro da força.

2. Feitiço do Tempo (Groundhog Day, 1993): O comediante Bill Murray é um repórter metereológico mal-humorado que viaja até uma pequena cidadezinha do interior para cobrir "O Dia da Marmota", um evento local. Mas algo mágico acontece e ele fica preso no tempo, repetindo sempre o mesmo dia. Sem pretenções (será?), o diretor Harold Ramis criou uma obra sensível, engraçada e cheia de mensagens subliminares.

3. O Homem do Futuro (Brasil, 2010): Wagner Moura, em mais um trabalho extremamente competente, faz um cientista que acidentalmente cria uma máquina do tempo e, no melhor estilo Marty McFly, volta 20 anos no passado exatamente para o fatídico dia onde deixou escapar o amor de sua vida (Alinne Moraes). Misturando elementos de vários filmes gringos sobre o tema, esta despretenciosa comédia nacional diverte com inteligência, mesmo abordando um tema já bastante explorado.

4. Perguntas Frequentes sobre Viagem no Tempo (F.A.Q. About Time Travel, 2009): Três nerds viajam para frente e para trás no tempo, durante as quais tentam evitar o encontro de suas múltiplas versões e descobrir quem quer assassiná-los. Pérola britânica de baixoorçamento que brinca com todas as referências dos filme do gênero.

5. 12 Macacos (Twelve Monkeys, 1985): O diretor Terry Gilliam é conhecido por suas obras cheias de fantasia e imaginação. Aqui ele coloca Bruce Willis e Brad Pitt lado a lado, num thriller de ficção futurista onde o destino da humanidade depende da erradicação de um perigoso virus que quase a extinguiu em 2035.

6. Crimes do Tempo (Los Cronocrímenes, 2007): Surpreendente filme espanhol onde sujeito entra acidentalmente em uma estranha máquina, descobre que regressou uma hora e meia no tempo e que deve ajudar seu "eu" passado a refazer seus passos, caso contrário, será apagado da existência. Ao tentar reparar as coisas, ele acaba danificando ainda mais a linha temporal com resutados desastrosos.

7. Planeta dos Macacos (Planet of Apes, 1968): Esqueça a refilmagem de Tim Burton realizada em 2001, o clássico sessentista é muito melhor! Não tem quem não se arrepie diante da cena onde Charlton Heston descobre a cabeça da Estátua da Liberdade escondida sob a areia (não assistiu? Que pena... acabei de contar o final!).

8. Série Exterminador do Futuro (Terminator, 1984, 1991, 2003 e 2009): Jim Cameron revolucionou o gênero por duas vezes com esta série, primeiro com o filme original, depois com a sequencia T2, apresentando efeitos visuais inovadores (para a época). Schwarzenegger faz um andróide que volta no tempo para eliminar aquela que seria a mãe do futuro líder da resistência dos homens contra as máquinas. 
9. A Máquina do Tempo (The Time Machine, 1960): Baseado no clássico de H. G. Wells, conta a história de um cientista (Rod Taylor) do século XIX que constrói uma máquina do tempo e viaja a um futuro distante para aprender o caminho da paz com a evolução dos homens. $O$ que ele encontra é tudo menos evolução.

10. Trilogia De Volta Para o Futuro (Back To The Future Trilogy, 1985, 1989 e 1990): Não satisfeito em criar uma pequena obra-prima juvenil com o original de 1985, Robert Zemeckis e Bob Gale criaram duas sequências igualmente empolgantes mostrando a existência de uma realidade paralela diferente da qual o Marty McFly (Michael J. Fox), o personagem principal, vivia. 
ANEXO II

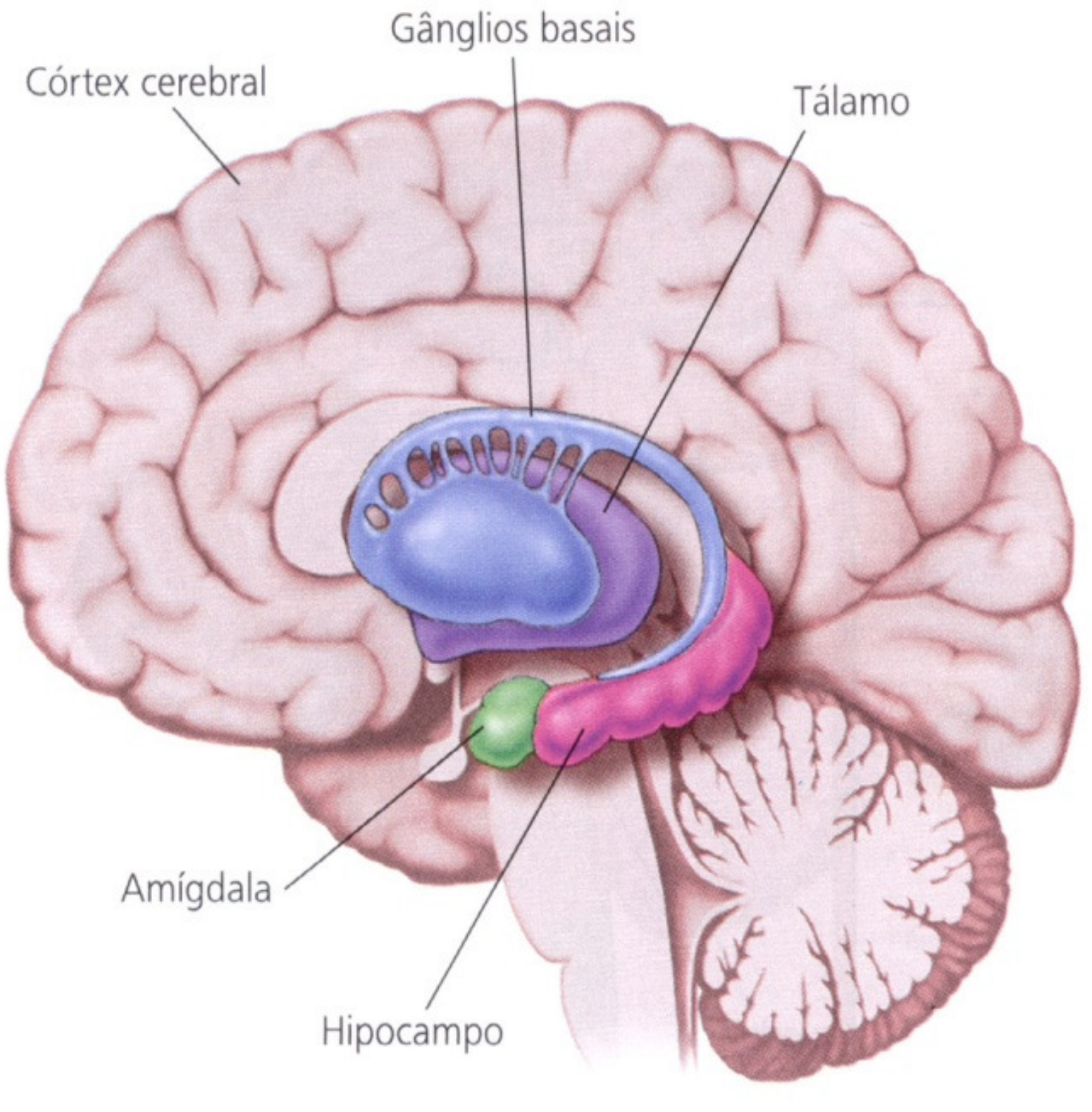

